UNIVERSIDADE DE SÃO PAULO

INSTITUTO DE GEOCIÊNCIAS

\title{
ESTUDOS DE CONSERVAÇÃO EM PEDRA
}

\author{
Eliane Aparecida Del Lama
}

Tese apresentada ao Concurso de LivreDocência junto ao Departamento de Mineralogia e Geotectônica do Instituto de Geociências da Universidade de São Paulo, na Área de Conhecimento de Geoconservação.

São Paulo 
Ficha catalográfica preparada pelo Serviço de Biblioteca e Documentação do Instituto de Geociências da Universidade de São Paulo

Del Lama, Eliane A.

Estudos de conservação em pedra / Eliane Aparecida Del Lama. - São Paulo, 2016.

xii, 187 p.: il.

Tese (Livre-Docência) : IGc/USP

1. Pedra 2. Patrimônio histórico 3. Restauração 4. Geoconservação 5. Educação patrimonial I. Título 
Aos que se foram, mas ainda tão presentes (na cronologia):

Cláudia Viana Monteiro

Mauricio Del Lama

Aparecida Carlucci Del Lama

Sumiko Dehira

Antonio Del Lama 


\section{AGRADECIMENTOS}

Chegar neste ponto na carreira implica a colaboração de muitas pessoas e instituições.

Tenho muita clareza que não teria chegado até aqui sem o suporte financeiro da FAPESP que possibilitou, principalmente, a aquisição de equipamentos não destrutivos e o financiamento de análises laboratoriais. Foram 3 auxílios à pesquisa, 1 auxílio-viagem e bolsas concedidas aos meus orientados ( 2 iniciações científicas, 2 mestrados e 1 doutorado). E apenas considerando os apoios obtidos após minha contratação como docente pelo Instituto de Geociências-USP, já que eu mesma fui bolsista da FAPESP de mestrado, doutorado e pós-doutorado.

Minha carreira tem 3 fases muito distintas e para cada uma destas fases há uma pessoa que foi crucial para o desenvolvimento de cada ciclo, mesmo estando o último em andamento.

A 1a fase: da graduação até o doutorado. Ao sempre mestre prof. Antenor Zanardo, apesar de fazer muitos anos que não trabalhamos mais juntos, sempre procurei me pautar pelos seus ensinamentos científicos e conduta ética.

A 2a fase: do pós-doutorado até o ingresso no IGc como docente. Com o desenvolvimento dos trabalhos do pós-doc, percebi que apesar de gostar muito (e ainda gosto) da temática sobre metamorfismo, não queria mais seguir nesta linha. À querida profa. Maria Angela Fornoni Candia, que foi minha supervisora no pós-doc e me ajudou a passar por esta fase de transição.

A 3a fase: contratação como docente pelo IGc até os dias atuais. Começar uma área nova tem seus desafios, que no meu caso foi muito facilitado com a colaboração do prof. José Delgado Rodrigues. Especialista internacional da área de conservação, ajudou a implantar esta nova linha de pesquisa no IGc, e mesmo pelo Brasil afora.

Aos três, meu muito obrigada! 
Ao IGc-USP e principalmente ao Departamento de Mineralogia e Geotectônica, por ter acreditado neste projeto. Agradecer às pessoas do IGc envolveria colocar quase toda a lista de contato telefônico, assim faço aqui um agradecimento geral, destacando os colegas com quem dividi disciplinas e comissões. Foi e é um aprendizado constante.

Aos meus alunos e ex-orientados, vocês são coautores deste trabalho e a razão para eu sempre querer aprender mais.

Ao Stone Course 2011 (participantes, professores e staff do ICCROM), gratíssima pelo compartilhamento de conhecimento e experiências.

Aos colegas da conservação pelas colaborações e trocas de experiências, Heloisa Frascá, Thais Sanjad e Emilio Barroso.

À minha família que é e sempre será meu porto seguro.

E ao Lauro Kazumi Dehira. Meu colaborador, revisor, diagramador, fotógrafo, motorista, companheiro de campo e de vida, você também é coautor deste trabalho. 
O tempo é destruidor, o homem ainda mais.

Ovídio, poeta romano 


\section{RESUMO}

Del Lama, E.A. 2016. Estudos de conservação em pedra. Tese de Livre-Docência, Instituto de Geociências, Universidade de São Paulo, São Paulo, 189 f.

No contexto das atividades humanas ligadas às construções, os materiais rochosos são denominados de pedra.

O uso da pedra pelo Homem é milenar e este trabalho faz uma retrospectiva desse uso em edificações, enfocando na conservação do patrimônio pétreo.

Apesar do protagonismo da pedra, também as argamassas históricas são abordadas.

Ao contrário do senso comum, a pedra não é eterna, e as várias formas de deterioração apresentadas aqui ratificam essa premissa.

A intervenção no patrimônio histórico é uma ação multidisciplinar e deve ser baseada em documentos e textos doutrinários, com métodos próprios e comprovados, sempre norteados pelo método científico e realizada por profissional habilitado, ou seja, o conservadorrestaurador.

Os principais tratamentos da pedra são aqui discutidos, quais sejam: limpeza, consolidação e eliminação da colonização biológica.

Considerando a inserção do patrimônio histórico nas cidades, aborda-se o geoturismo urbano, apontando a importância de roteiros geológicos para a conservação destes bens e a popularização dos conceitos geocientíficos.

A Educação Patrimonial ainda é um desafio a ser vencido no Brasil, para que ela auxilie na preservação do nosso patrimônio.

Palavras-chave: pedra; patrimônio histórico; restauração; geoconservação; educação patrimonial 


\begin{abstract}
Del Lama, E.A. 2016. Studies of conservation in stone. Tese de Livre-Docência, Instituto de Geociências, Universidade de São Paulo, São Paulo, 189 f.
\end{abstract}

In the context of construction activities, rocky materials are called stone.

The use of stone as building material dates back to the beginning of Mankind, and this work aims to provide a retrospective of this use, focusing on the conservation of stone-based heritage.

Despite the principal focus being on stone, historical mortars are also addressed.

Contrary to common sense, stone is not eternal, and the various forms of deterioration presented here confirm this premise.

Intervention in heritage is a multidisciplinary action and should be based on doctrinal documents and texts, with appropriate and proven methods, always guided by scientific method and performed by qualified professionals, i.e., conservator-restorers.

The principal treatments for stone are discussed here, and these are cleaning, consolidation and the elimination of biological colonization.

Taking into consideration the heritage assets located within cities, a discussion of urban geotourism is presented, pointing out the importance of geological trails for conserving these assets and popularizing geoscientific concepts.

Heritage Education is still a challenge to be overcome in Brazil for it to assist in the preservation of our common Heritage.

Keywords: stone; historical heritage; restoration; geoconservation; heritage education 


\section{SUMÁRIO}

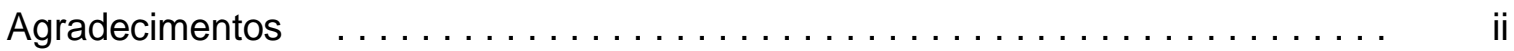

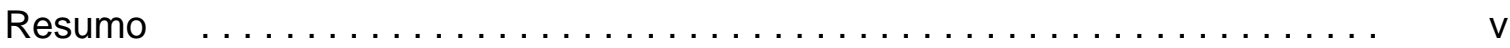

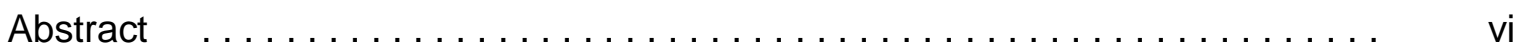

Sumário $\quad \ldots \ldots \ldots \ldots \ldots \ldots \ldots \ldots \ldots \ldots \ldots \ldots \ldots \ldots \ldots \ldots \ldots \ldots \ldots \ldots \ldots$

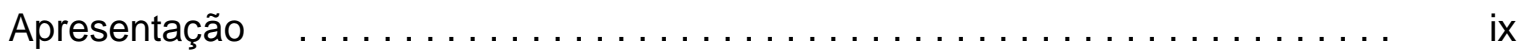

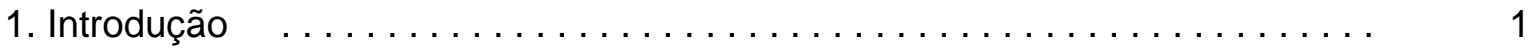

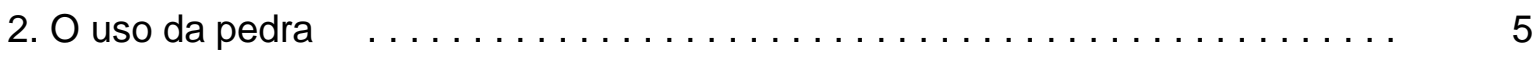

3. Contexto histórico e textos doutrinários $\quad \ldots \ldots \ldots \ldots \ldots \ldots \ldots \ldots \ldots \ldots \ldots \ldots$

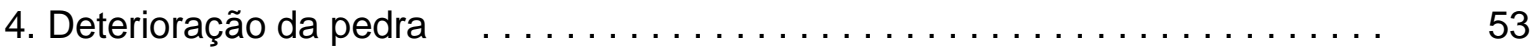

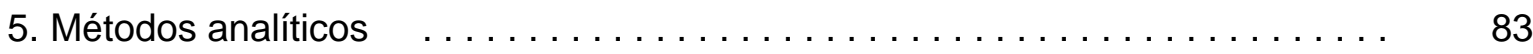

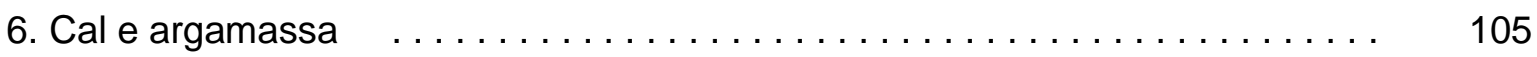

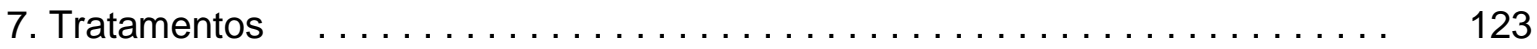

8. Geoconservação: aspectos educacionais e divulgação das geociências ～. . 147

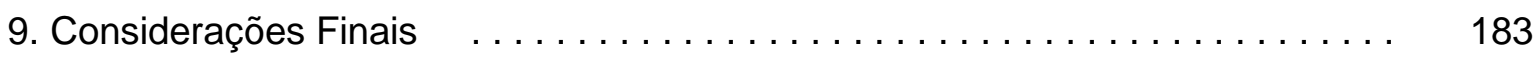




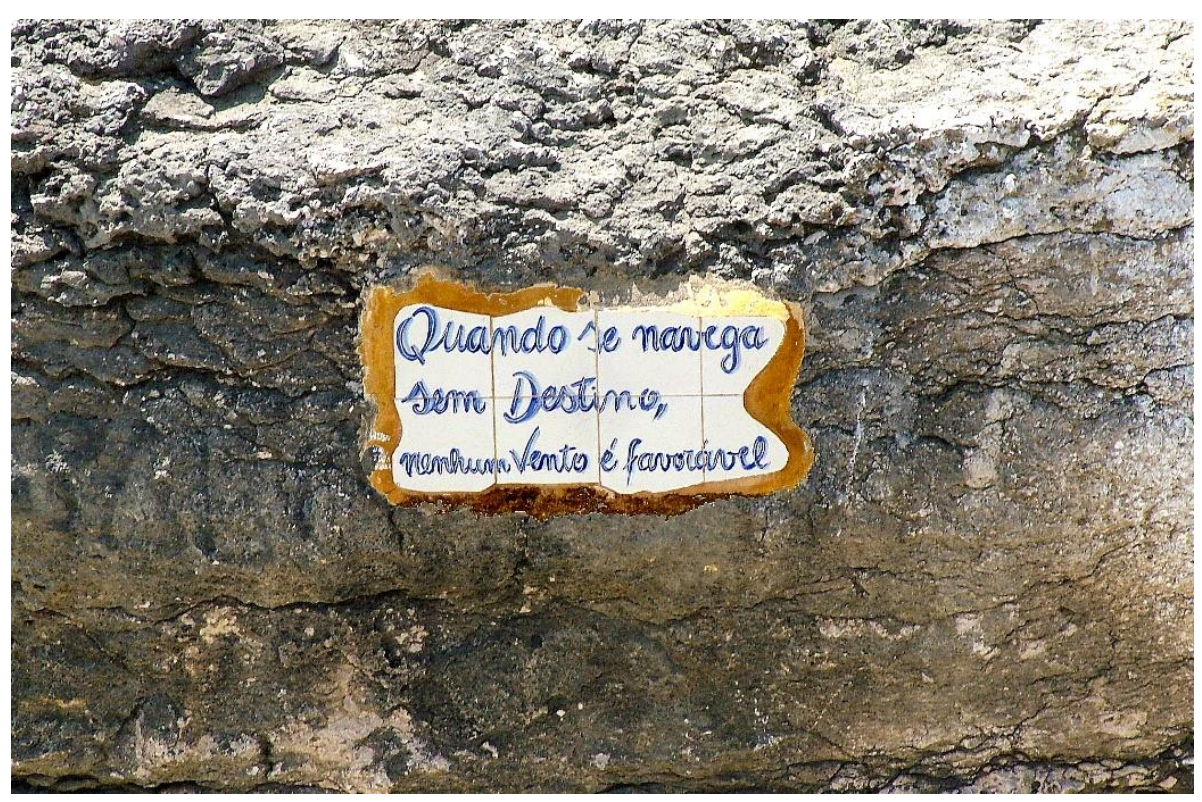

Ericeira, Portugal 


\section{Apresentação}

Esta tese é parte integrante dos requisitos para obtenção do título de livre-docente.

Não é uma tese no sentido de apresentar o resultado de uma investigação e dados inéditos, mas antes é um texto que sistematiza as pesquisas e a produção científica da autora, opção prevista pelo Regimento Geral da Universidade de São Paulo para obtenção deste título acadêmico.

As ilustrações aqui apresentadas são frutos dos trabalhos de campo e viagens da autora.

Apesar de ser consenso que a contribuição do geocientista no estudo e preservação do patrimônio construído é importante, na prática ainda se nota que os projetos de conservação e restauro nem sempre contam com o apoio de profissionais da geologia.

Este trabalho mostrará que este profissional relaciona-se intrinsicamente aos estudos do patrimônio pétreo.

Os temas aqui abordados são similares ao programa da disciplina de pós-graduação GMG5867 - Conservação e restauração do patrimônio histórico construído, oferecida no Instituto de Geociências da USP (IGc-USP).

Esta disciplina foi ministrada pela primeira vez em 2006 pelo geólogo e cientista da conservação José Delgado Rodrigues (pesquisador aposentado do Laboratório Nacional de Engenharia Civil - LNEC, Portugal), tendo se constituído em um embrião de uma nova linha de pesquisa dentro do Instituto de Geociências. Desde então, a disciplina vem sendo ministrada, sob responsabilidade desta autora, inserindo outros temas com o passar dos anos.

$\mathrm{Na}$ confecção desta tese, foram utilizadas também anotações de aula do $17^{\text {th }}$ International Course on Stone Conservation ministrado pelo ICCROM (International Centre for the Study of the Preservation and Restoration of Cultural Property) em Roma (Itália), do qual a autora participou em 2011 (Figura I).

$\mathrm{Na}$ linha deste curso, mas em uma versão mais condensada, foi realizado em dezembro de 2014 em Belo Horizonte o curso Caracterização e Conservação da Pedra patrocinado pela UFMG (Universidade Federal de Minas Gerais) e IPHAN (Instituto do Patrimônio Histórico e Artístico Nacional) e organizado pelo prof. Antonio Gilberto Costa, cuja coordenação científica foi do citado prof. Delgado Rodrigues, e que teve a colaboração de diversos 
profissionais internacionais e nacionais da área da Ciência da Conservação ministrando aulas (Figura II).

Na presente tese, não é ideia se esgotar o tema em cada capítulo, muito pelo contrário. É apenas um fio condutor para o leitor se inteirar e aprofundar o assunto, a partir das referências bibliográficas apresentadas. Mais importante do que conhecer o assunto é saber onde buscá-lo (Figura III). Optou-se por colocar as referências bibliográficas em cada capítulo para facilitar ao leitor a busca pelas fontes e também dar independência aos temas.

Também é um pano de fundo para a autora referenciar os artigos publicados por seu grupo de pesquisa desde que começou a trabalhar nesta temática em 2004, no IGc-USP. Por conta disso, alguns temas são tratados com mais profundidade.

Considera-se que hoje a temática está consolidada no IGc-USP e dois fatos foram cruciais para este cenário. Em 2011 foi criado o NAP (Núcleo de Apoio à Pesquisa) Geohereditas Patrimônio Geológico e Geoturismo e, no ano seguinte, foi criada a linha de pesquisa Patrimônio Geológico Natural e Construído e Geoconservação no Programa de PósGraduação em Geociências (Mineralogia e Petrologia).

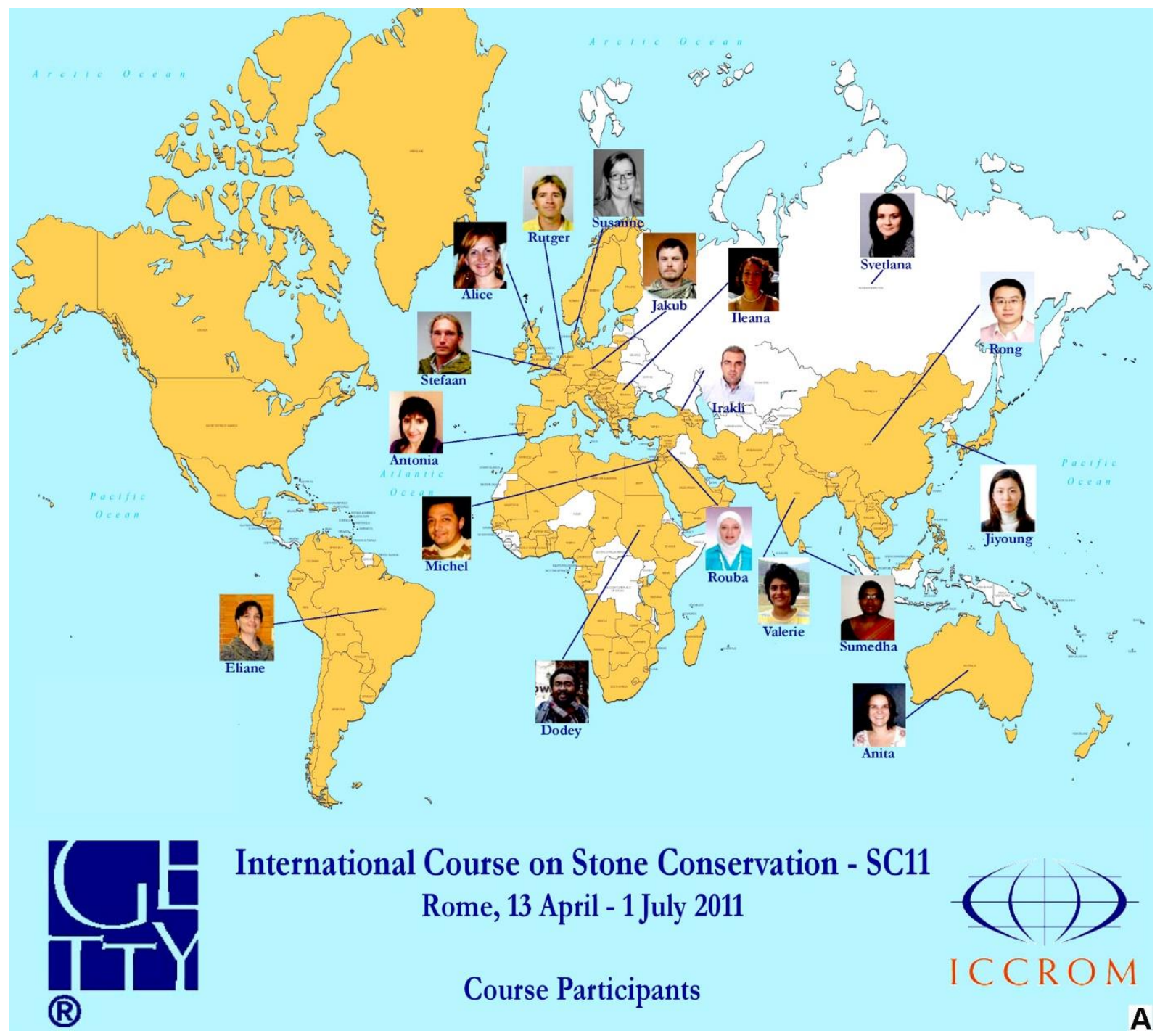



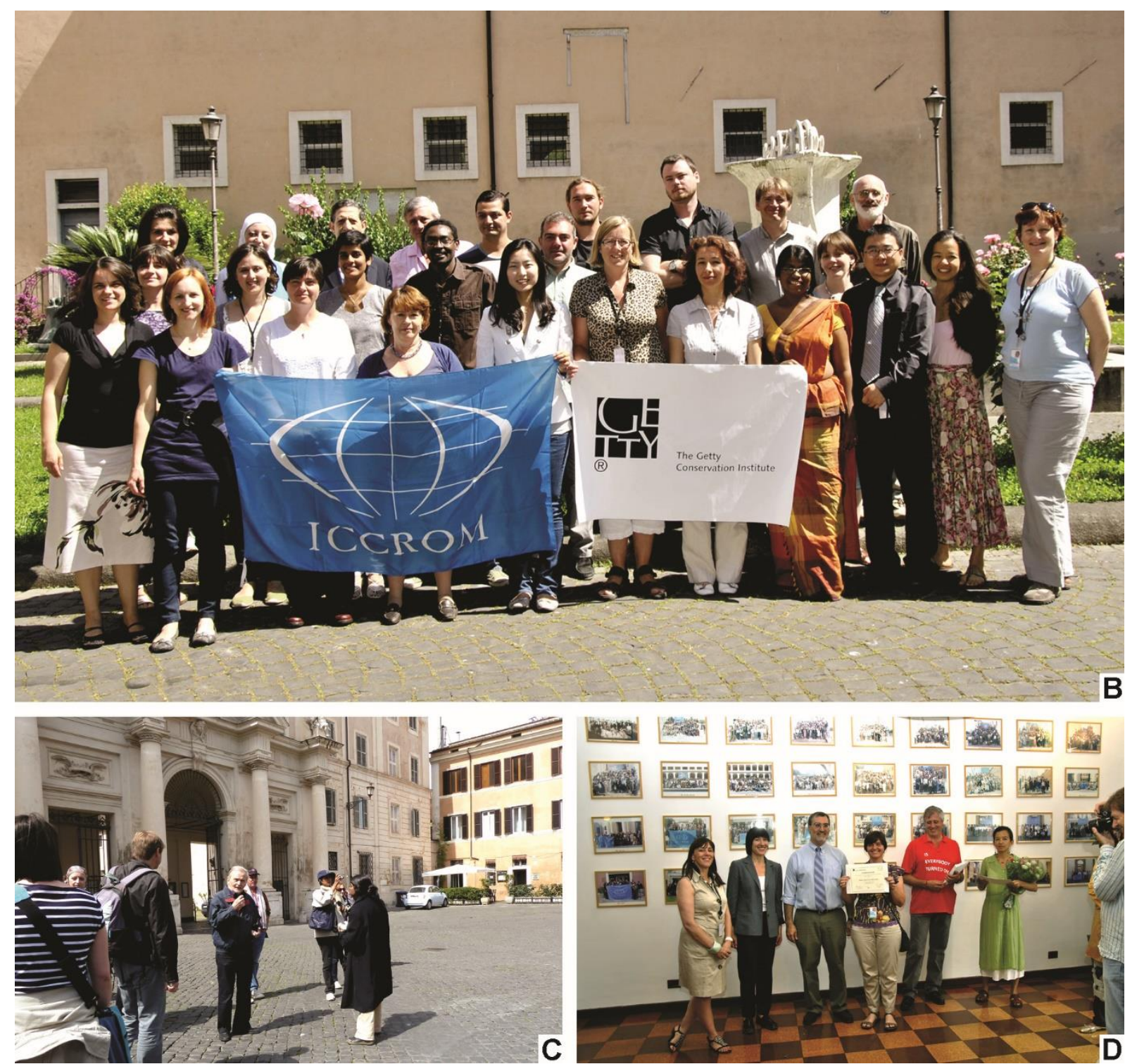

Figura I. Curso internacional em Conservação da Pedra, 13 de abril a 01 de julho de 2011, Roma, Itália. A e B. Participantes. C. Aula de campo em Roma. D. Conclusão do curso.

Esta linha de atuação é um campo promissor para o geólogo e importante para a sociedade, pois, além de contribuir para o avanço do conhecimento científico, permite intervir em apoio a situações concretas como contribuição direta na preservação da Herança Cultural do País. 


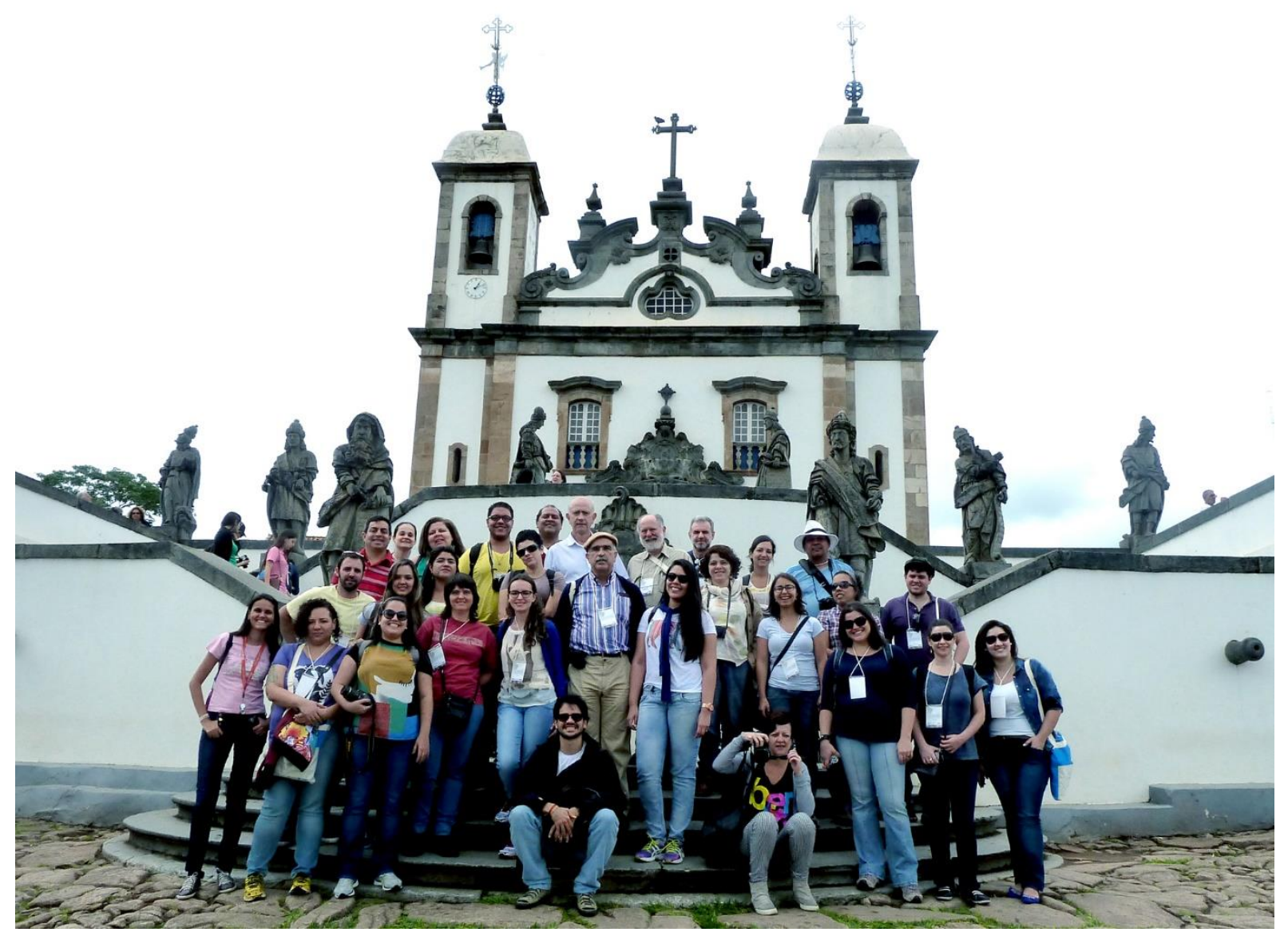

Figura II. Participantes do curso nacional em Caracterização e Conservação da Pedra, 01 a 12 de dezembro de 2014, Belo Horizonte, MG. Aula de campo em Congonhas, MG.
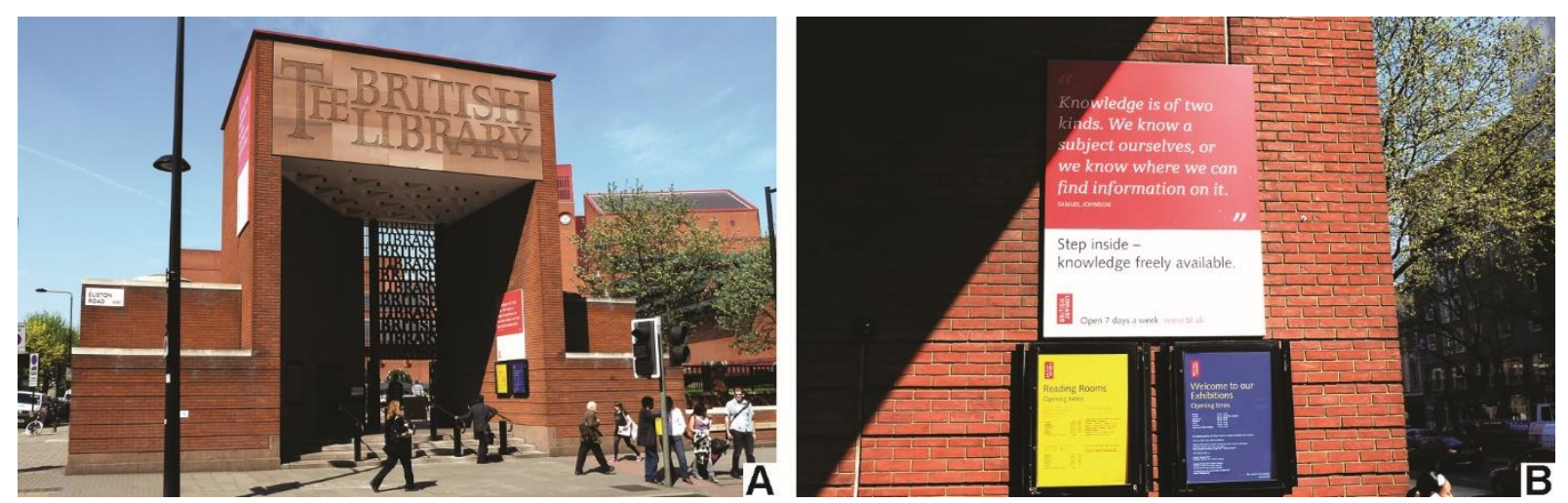

Figura III. Biblioteca Britânica em Londres. A. Fachada do edifício na Euston Road. B. Cartazes na entrada convidando pessoas ao conhecimento e informativos. 


\section{Introdução}

As Geociências estudam os materiais rochosos, material este abundante na natureza e encontrado em diversos ambientes, fornecendo uma grande variedade de cores, texturas e resistências, constituindo-se num material de construção por excelência.

Neste contexto, os materiais rochosos trabalhados ou usados pelo Homem são designados como pedra, e será esta a forma usada aqui sempre que se considerar a obra. Se o contexto for a sua origem, a sua evolução ou outro contexto petrológico, permanece a utilização do termo rocha.

Nesta tese serão abordados aspectos referentes à conservação da pedra sob a ótica das Geociências. E apesar do foco principal na pedra, as argamassas também serão discutidas. Assim, serão apresentados os materiais e seus problemas, aspectos doutrinários, técnicas usadas no diagnóstico e tratamentos, finalizando com roteiros geológicos nas cidades, com base nas construções e monumentos pétreos, estratégicos e importantes para a disseminação dos conceitos geocientíficos e a preservação do patrimônio.

As contribuições que as Geociências podem fornecer para a preservação da Herança Cultural, em conjunto com as outras áreas de conhecimento, são inúmeras (Del Lama 2006), e agregam informações tais como: identificação das rochas usadas em construções históricas; estudo de intemperismo de rochas em monumentos; caracterização mineralógica de azulejos antigos; identificação de pigmentos e caracterização de argamassas de pinturas artísticas; geoarqueologia (estudos de proveniência, composição e idade de objetos arqueológicos; pinturas rupestres; caracterização de sítios arqueológicos sob pontos de vista geomorfológico e sedimentológico e de localização e identificação de sítios subterrâneos); além da preservação e divulgação do patrimônio geológico natural.

Desta forma, a participação de geocientistas na investigação e solução de problemas relacionados com o estudo e conservação da Herança Cultural é pertinente e tem crescido progressivamente no Brasil, conforme se observa pelo aumento de trabalhos apresentados em congressos e simpósios específicos, em periódicos, e trabalhos de conclusão de curso, mestrado e doutorado, conforme será demonstrado no decorrer dos capítulos subsequentes.

Comecemos então pelas definições de monumento e patrimônio.

Monumento vem do latim monumentum, que por sua vez vem de monere (avisar, lembrar), lembrança de alguma coisa. Sua finalidade é lembrar o passado. 
Patrimônio é um bem que foi herdado, é um legado que recebemos de nossos ancestrais e que tem de ser repassado para as futuras gerações.

O Patrimônio Cultural é a expressão criativa de existência de pessoas no passado, no passado próximo e no presente, com suas tradições, crenças e realizações.

Choay (2006) define Patrimônio Histórico como um bem destinado ao usufruto de uma comunidade que se ampliou a dimensões planetárias, constituído pela acumulação contínua de uma diversidade de objetos que se congregam por seu passado comum: obras e obrasprimas das belas-artes e das artes aplicadas, trabalhos e produtos de todos os saberes e savoir-faire dos seres humanos.

No contexto brasileiro, o escritor Mário de Andrade assim definiu Patrimônio Artístico Nacional: "todas as obras de arte pura ou de arte aplicada, popular ou erudita, nacional ou estrangeira, pertencentes aos poderes públicos, e a organismos sociais e a particulares nacionais, a particulares estrangeiros, residentes no Brasil' (apud Lemos 1987).

A definição oficial de Patrimônio Histórico e Artístico Nacional aparece no Decreto-lei n.25 de 1937: o conjunto dos bens móveis e imóveis existentes no país e cuja conservação seja de interesse público, quer por sua vinculação a fatos memoráveis da história do Brasil, quer por seu excepcional valor arqueológico ou etnográfico, bibliográfico ou artístico (Brasil 1937).

A tendência hoje é diminuir a importância destas distinções encontradas em diversas definições e integrar todos os aspectos do patrimônio.

Em relação ao termo patrimônio cultural o seu significado tem evoluído nas últimas décadas. Originalmente, referia-se somente a obras-primas de valor artístico e histórico, sendo que atualmente é usado mais amplamente e cobre tudo que tem significado particular para as pessoas. No presente, o patrimônio mundial é a soma do patrimônio cultural e natural. Se nós quisermos entender as diversidades culturais que existem no mundo, nós não podemos separar cultura da natureza. Natureza e cultura são intrinsicamente ligadas, sendo que o homem modificou o ambiente e concomitantemente $o$ ambiente influenciou a atividade humana (UNESCO 1972).

E por que se deve conservar o patrimônio?

Porque ele é único e insubstituível; porque transmite diversas mensagens e valores (histórico, artístico, estético, político, religioso, social, espiritual, científico, natural) que contribui para dar significado à vida das pessoas; porque representa a identidade de um grupo social; porque assegura o entendimento da memória social e seus bens representativos; porque é fonte de conhecimento; e também porque é fonte de desenvolvimento econômico.

E como se conserva o patrimônio?

No caso de edifícios, uma das melhores forma de preservação seria manter o bem cultural em uso.

Intervir no patrimônio é uma atividade que requer suporte científico com metodologia específica e abordagem multidisciplinar, considerando o seu contexto histórico e a 
caracterização da sua constituição. O objeto em questão tem uma carga cultural importante e inclui sua componente material e sua componente de valores, que devem ser identificadas e preservadas.

A intervenção sempre vai retirar ou subtrair autenticidade do objeto restaurado, nunca adiciona, por isso é necessária uma atitude de prudência nesse trabalho.

Por outro lado, não existem receitas prontas mas há um procedimento metodológico que sempre deve ser seguido.

Inicia-se por uma fase prévia de estudos para identificar e caracterizar os problemas e procurar uma estratégia de conservação. Os riscos de danificar o objeto são grandes, assim, exige-se uma ação crítica, ponderada e responsável. As cartas patrimoniais são orientadoras e podem ajudar na definição da estratégia. Todas as atividades devem ser documentadas, assim como o estado prévio.

E quem tem responsabilidade da intervenção é o conservador-restaurador, profissional habilitado para tal função.

A intervenção é sempre datada à época de sua realização, ela ajuda a conservar o bem, mas não adiciona autenticidade a ele. Qualquer bem deveria estar constantemente sob conservação preventiva e manutenção, diminuindo assim as necessidades de intervenções de restauração.

Finalizamos esta introdução com um ponto-chave: nunca esquecer o caráter excepcional da restauração.

\section{REFERÊNCIAS}

Brasil. 1937. Decreto-lei $n^{\circ} .25$, de 30 de novembro de 1937. Disponível em: http://www.planalto.gov.br/ccivil_03/decreto-lei/Del0025.htm.

Choay F. 2006. A alegoria do patrimônio. São Paulo, Estação Liberdade, UNESP, 288 p.

Del Lama E.A. 2006. Geologia e Herança Cultural. Revista Brasileira de Geociências, 36(2): 379-381.

Lemos C.A.C. 1987. O que é Patrimônio Histórico. Coleção Primeiros Passos, 51. 3aㅗ Reimpressão da 5ª edição: 2006. São Paulo, Editora Brasiliense, 116 p.

UNESCO - Organização das Nações Unidas para a Educação, a Ciência e a Cultura. 1972. Convenção para a proteção do Patrimônio Mundial, Cultural e Natural. 16 p. Disponível em: http://whc.unesco.org/archive/convention-pt.pdf. 


\section{O uso da pedra}

A pedra foi o primeiro material geológico que os hominídeos aprenderam a manusear. Os primeiros seixos lascados datam de 3.000.000 anos (Hummel 1999).

A descoberta e a utilização dos materiais geológicos foram tão importantes que nomearam os períodos da civilização humana: Idade da Pedra, Idade Calcolítica, Idade do Bronze e Idade do Ferro. Esses materiais eram usados como instrumentos, armas, utensílios, adornos, abrigo e auto-expressão (pinturas e inscrições rupestres).

A arte paleolítica europeia iniciou-se ca. 35.000 anos atrás, e os materiais geológicos constituíam o suporte da pintura na forma de afloramentos rochosos ou tetos e paredes de caverna, e no fornecimento das cores, oriundas dos pigmentos minerais. Exemplos excepcionais de pinturas rupestres ocorrem na França (Chauvet e Lascaux) e na Espanha (Altamira) e exemplo de inscrições ocorrem em Portugal (Vale do Côa). Um exemplo no Brasil são as pinturas rupestres da Serra da Capivara (Piauí).

Em 4.000-3.000 a.C. surgem as construções megalíticas, as primeiras formas de arquitetura monumental da pré-história usando a pedra, utilizados para fins funerários e rituais. Alguns exemplos são o Cromeleque dos Almendres (Portugal), Alinhamento de Kermario-Carnac (França), Dólmens de Antequera (Espanha) e Stonehenge (Grã-Bretanha). Em seguida, surgem as pirâmides no Egito, estas sim verdadeiras edificações em pedra.

E também há exemplos onde não houve a extração da pedra na edificação, e sim a escavação do próprio maciço rochoso como na cidade de Petra, na Jordânia, esculpida no arenito local, ou habitações escavadas em tufo na Anatólia, Turquia (Figura 2.1).

Grande parte destas construções é exemplo de arquitetura vernacular, quando são utilizados materiais provenientes do próprio ambiente, conferindo seu caráter regional.

Seguiu-se pela utilização do mármore polido na Grécia e depois os marmi antichi usados em Roma durante o Império Romano.

Sobre extração de pedra, Vitruvius, arquiteto romano que viveu no século I a.C., diz que ela deve ser extraída 2 anos antes da construção do edifício, no verão, e ser exposta ao tempo. Após este período, aquelas que foram alteradas devem ser usadas nas fundações, e as outras devem ser usadas na parte do edifício que está acima do solo (Burman \& Drury 2006). Considerando a quantidade de pontes, portais, paredes, templos e outras estruturas que ainda perduram após 2.000 anos, esta regra deve ter sido uma prática comum. 

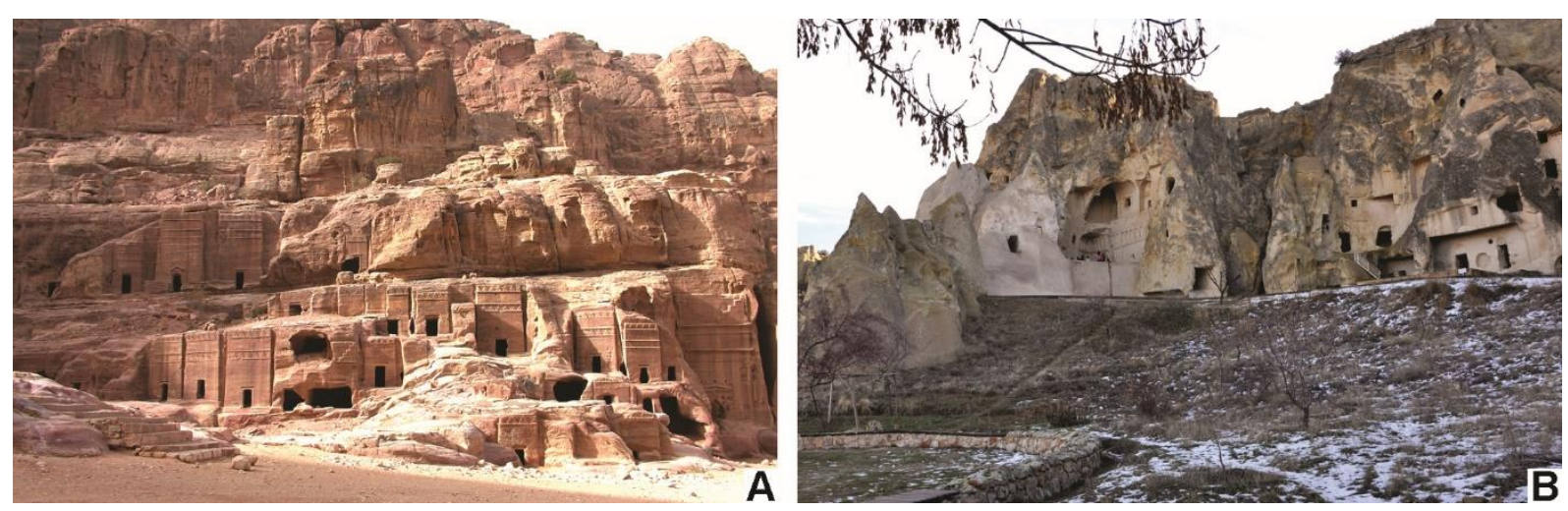

Figura 2.1. Exemplos de edificações esculpidas no próprio afloramento rochoso. A. Sítio Arqueológico de Petra, Jordânia. B. Museu a céu aberto em Göreme, Capadócia, Turquia. Fotografias: Lauro K. Dehira.

A arte e a técnica de trabalhar a pedra é chamada de estereotomia (do grego, stereos-sólido, tomé-corte). Os povos da Antiguidade considerados como os mais avançados nesta arte foram os gregos e os etruscos.

Os instrumentos para esculpir a pedra (Figura 2.2) não mudaram muito desde os primeiros usuários, uma vez que são necessários basicamente um martelo e uma variedade de ponteiras e cinzéis, que percebemos pelas marcas que deixaram nas obras que produziram. O artesão da pedra era considerado tão importante que há esculturas temáticas da arte de lavrar a pedra. Rockwell (1993) descreve as diferentes ferramentas para diferentes tipos de pedra utilizadas desde os tempos antigos, ilustrando as marcas que estes instrumentos deixaram ao trabalhar a pedra. Dehejia \& Rockwell (2011) discutem o acabamento de templos na Índia, onde se começava a escavar no topo e se seguia em direção à base, mas onde o nível do chão não era alcançado, concluindo que o termo finalizado pode ser bem flexível. Também descrevem os instrumentos usados para esculpir rochas vulcânicas do Planalto do Decã e granitos de quatro sítios espalhados pelo país.

$\mathrm{Na}$ Antiguidade era comum dar um acabamento na superfície pétrea, seja pela pintura direta da pedra, seja pelo revestimento de argamassa e pintura (Figura 2.3).

No Brasil, a arte da cantaria foi introduzida pelos portugueses. Pereira et al. (2007) descrevem vários exemplos concentrados em Ouro Preto, onde foram usados quartzito, xisto verde, canga e esteatito (pedra-sabão). Apesar da utilização da cantaria ter-se iniciado desde o século XVI, é no século XVIII que alcança seu esplendor em Minas Gerais.

Já no Paraná, este ofício é inserido pelos imigrantes italianos no século XIX (Liccardo 2010).

Além da utilização da pedra natural, existia também a técnica do uso dos falsos mármores, que consistia de pinturas em diversos suportes (até mesmo a própria pedra) que imitavam o mármore, tendo sido usadas na Antiguidade e no Renascimento.

Foi uma técnica comum em toda parte, por exemplo, usada no Parlamento (Figura 2.4) e na Ópera de Budapeste. Foi trazida para o Brasil pelos portugueses e há muitos exemplos nas igrejas de Minas Gerais (Costa 2009) e em construções históricas do Rio de Janeiro (Torem 2012). 

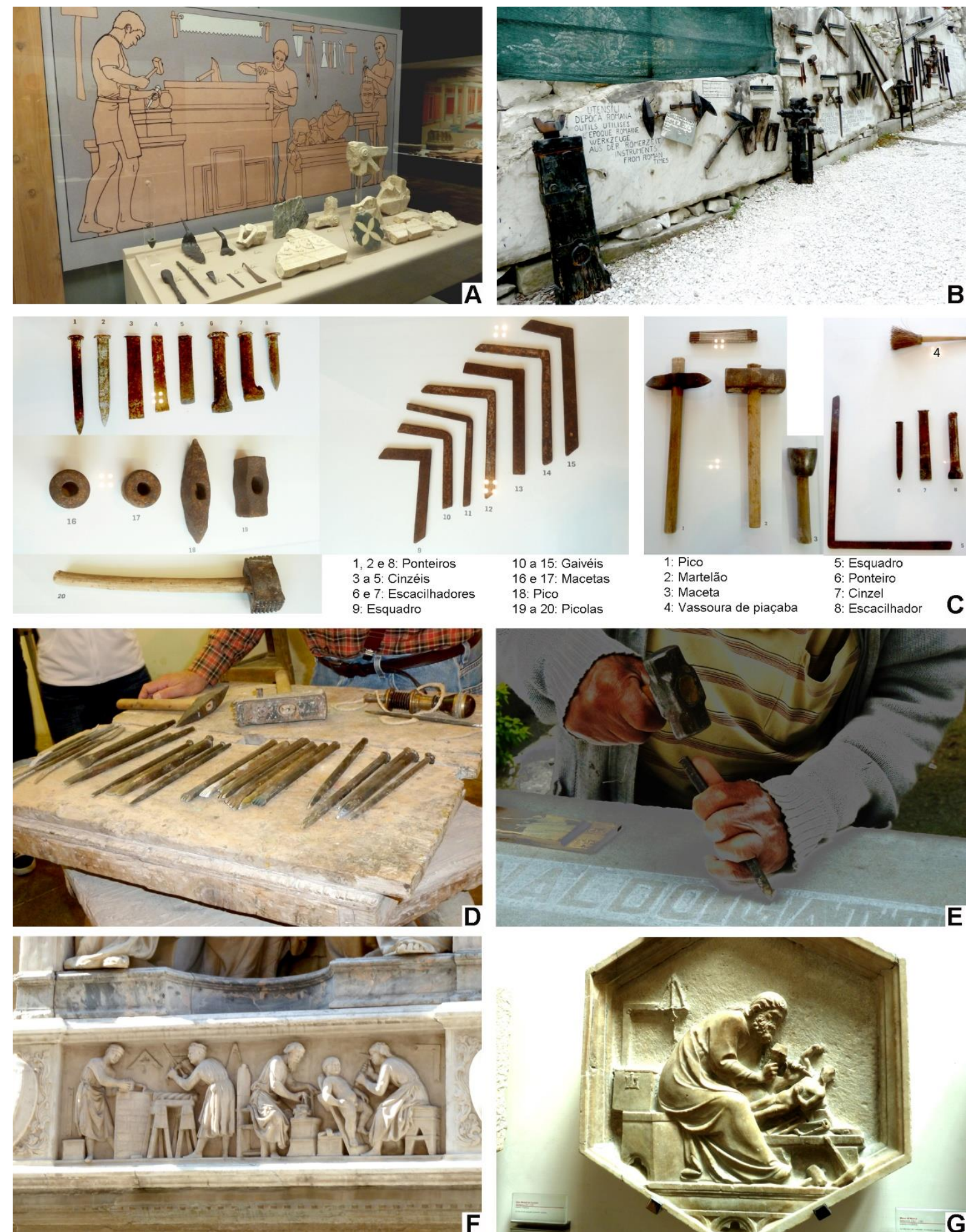

$\mathbf{F}$

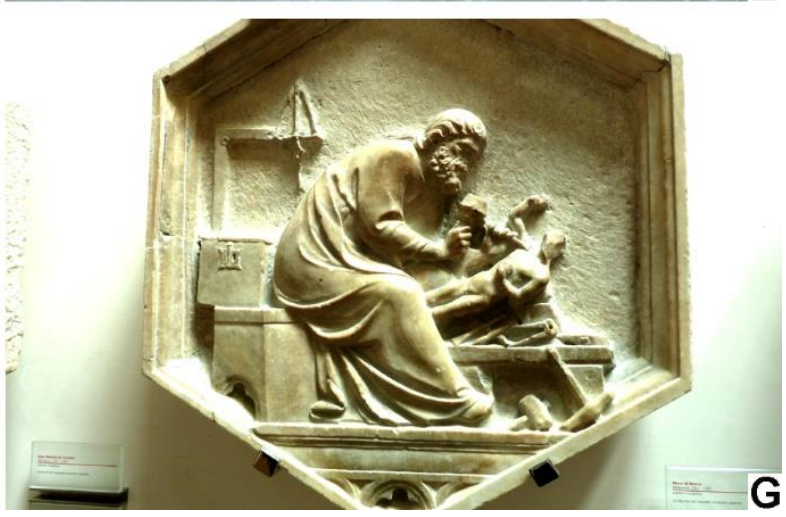

Figura 2.2. Instrumentos para trabalhar a pedra. A. Ferramentas encontradas no Sítio Arqueológico de Conimbriga, Portugal. B. Pedreira de mármore em Carrara, Itália. C. Museu da Pedra, Marco de Canavese, Portugal. D. Ateliê de Peter Rockwell em Roma, Itália. E. Entalhe da pedra no Cemitério da Consolação, São Paulo. F e G. Esculturas em mármore em Florença, Itália. G. Fidia, o la Scultura de Andrea Pisano. 

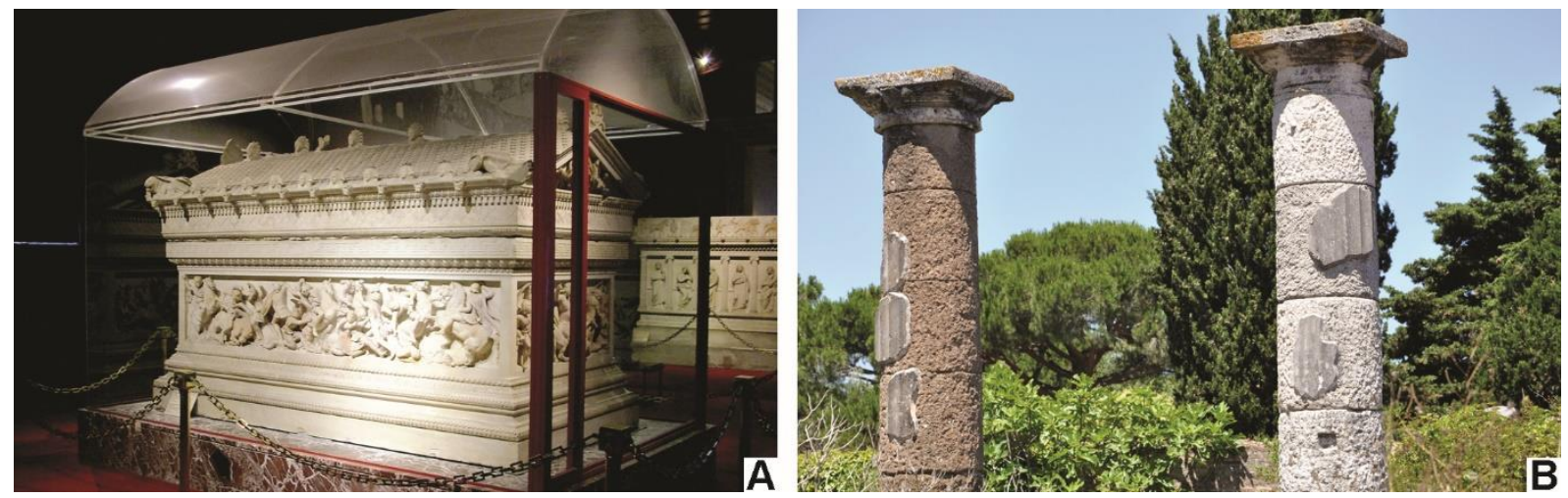

Figura 2.3. Revestimento na pedra. A. Restos de policromia no Sarcófago de Alexandre (séc. IV), Museu de Arqueologia de Istambul, Turquia. B. Restos de argamassa em colunas em Ostia Antica, Itália. Fotografias: Lauro K. Dehira.

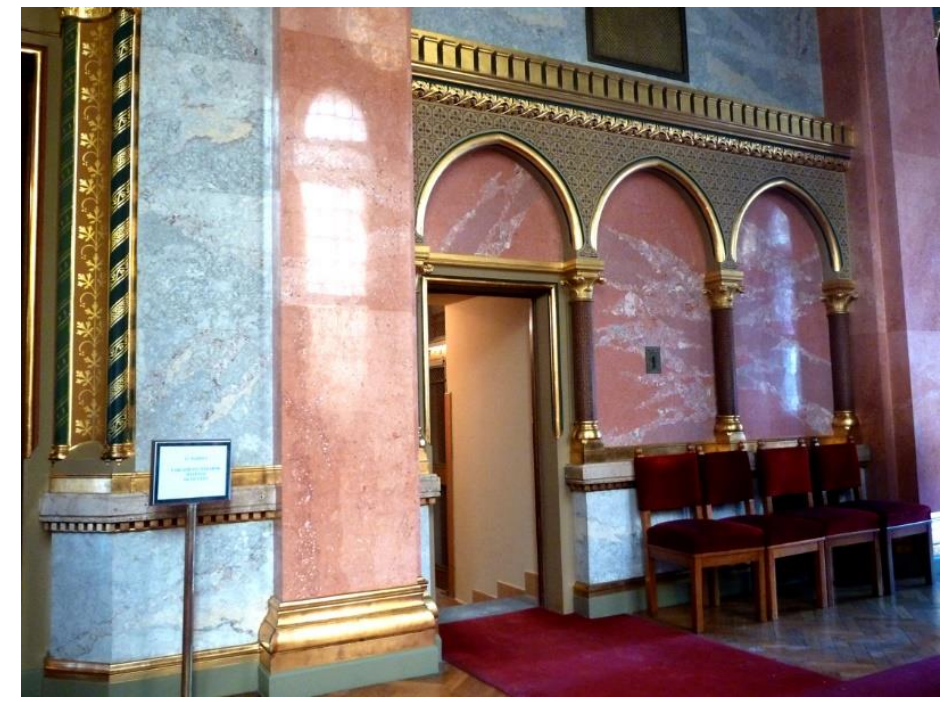

Figura 2.4. Falso mármore revestindo parede do edifício do Parlamento de Budapeste, Hungria.

\subsection{Técnicas construtivas romanas}

Os romanos não tiveram pedras adequadas para grandes construções como os gregos e os egípcios, mas desenvolveram com grande habilidade a técnica da utilização do elemento arco como suporte estrutural de edificações, usando tijolo e pedra.

$\mathrm{Na}$ Roma antiga foram usadas diversas técnicas construtivas, com variação do material empregado (pedra e/ou tijolo) e suas configurações. Algumas dessas técnicas são exemplificadas a seguir.

Opus quadratum: uso de blocos de pedra quadrados ou retangulares dispostos em fileiras paralelas, normalmente sem o uso de argamassa. Foi usada desde o século VI a.C.

Opus africanum: constituido por grandes blocos verticais, que se alternam com blocos verticais e horizontais. Foi mais utilizada no norte da África, mas a técnica foi também empregada na Sicília e Itália meridional pelos cartagineses. Não se tem registros dos edifícios 
cartagineses mais antigos, mas na Sicília há evidências de sua utilização desde o século IV a.C. (Adam 2005).

Opus incertum: consistia de blocos com formatos irregulares e dispostos aleatoriamente. Foi usado desde o século III a.C.

Opus caementicium: utilizava fragmentos de pedra ou adobe, assentadas com cimento ou argamassa. A descoberta do cimento foi fundamental para a arquitetura romana, permitindo a construção de coberturas abobadadas com proporções superiores àquelas feitas com pedra. Econômica e fácil de confeccionar, difundiu-se rapidamente em todo o mundo romano, sendo usada desde o fim do século III a.C. (Dessales 2006) (Figuras 2.5A e B).

Opus reticulatum: era alvenaria (pedra ou tijolo) com formato losangular dos blocos, comumente de tufo vulcânico, dispostos em um padrão reticulado. Na realidade, o formato era piramidal, sendo que a parte apical penetrava na parede, ficando à mostra a base losangular (Maciel 2007). Esta técnica foi usada nos séculos I e II. Formas mais irregulares (opus quasi reticulatum) foram usadas já no século II a.C. Em alguns casos poderia ser bicolor (Figura 2.5C).

Opus latericium: consistia de alvenaria de adobe (tijolo cozido ao sol) (Figura 2.5D). Foi uma técnica dominante do período imperial. Também foi utilizada a alvenaria de tijolo cozido em forno: opus testaceum. Este substituiu o opus latericium.

Opus vittatum: em Roma a técnica era constituída principalmente pela utilização de pequenos blocos de tufo, chamados de tufelli, de dimensões variáveis $(29 \times 16$ e $22 \times 10 \mathrm{~cm})$, que se alternavam com camadas de tijolo (Figura 2.5E). A expressão opus vittatum vem da aparência em bandas (Dessales 2006).

Opus mixtum: alternava camadas, ou porções, de tijolos com paralelepípedos de tufo. Foi particularmente bastante usada em Ostia Antica a partir do fim do século III (Figura 2.5F).

Opus spicatum: utilizava tijolos alongados cozidos em forno, dispostos em padrão de espinha de peixe, justapostos com inclinação aproximada de 45ํ (Figura 2.5G).

Opus sectile: consistia na confecção de painéis com pedras de formas variadas (Figura $2.5 \mathrm{H}$ ). O mosaico florentino ou pietra dura deriva do opus sectile. É uma técnica um pouco diferenciada, principalmente pela qualidade do acabamento, fazendo com que a junção das peças seja praticamente invisível. Um ateliê especializado nesta técnica foi fundado em 1588 pelo Grão-Duque Fernando I, em Florença. É considerada uma pintura em pedra e foi muito utilizada pelos florentinos durante o Renascimento (Figura 2.6).

O império romano tinha grande paixão pela pedra, tornando a cidade de Roma uma cidade de mármores multicoloridos. A diversidade dos litotipos é devida à importação das diversas colônias na região do Mediterrâneo para Roma (Figura 2.7). Giampaolo et al. (2008) afirmam que havia 41 principais pedras importadas, e descrevem vários monumentos e edifícios romanos confeccionados em pedra nacional e importada.

No século I a.C., o mármore foi importado em grande escala, proveniente principalmente da colônia romana Luna (hoje Luni), perto de Carrara, chegando no porto de Ostia. Em épocas mais recentes, o mármore vinha de construções romanas mais velhas, promovendo a reciclagem da pedra (Heiken et al. 2005). 

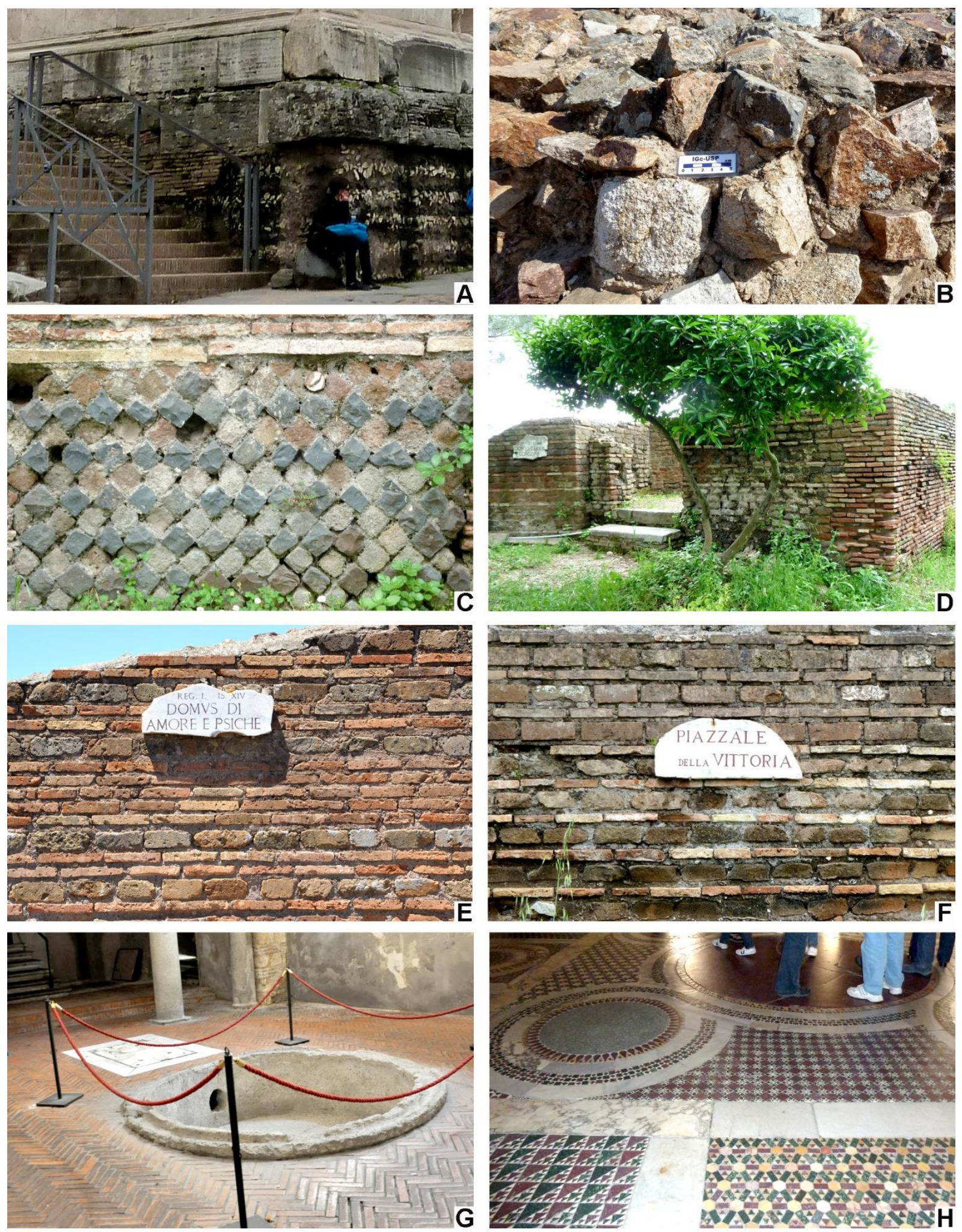

Figura 2.5. Técnicas construtivas romanas. A. Opus caementicium, base do Arco de Tito, Roma, Itália. B. Opus caementicium, anfiteatro de Mérida, Espanha. C. Opus reticulatum. D. Opus latericium. E. Opus vittatum. F. Opus mixtum. C a F: Ostia Antica, Itália. G. Opus spicatum, Basilica di Santa Restituta, Nápoles, Itália. H. Opus sectile, Igreja Santa Maria in Cosmedin, Roma, Itália. Fotografias E e G: Lauro K. Dehira. 

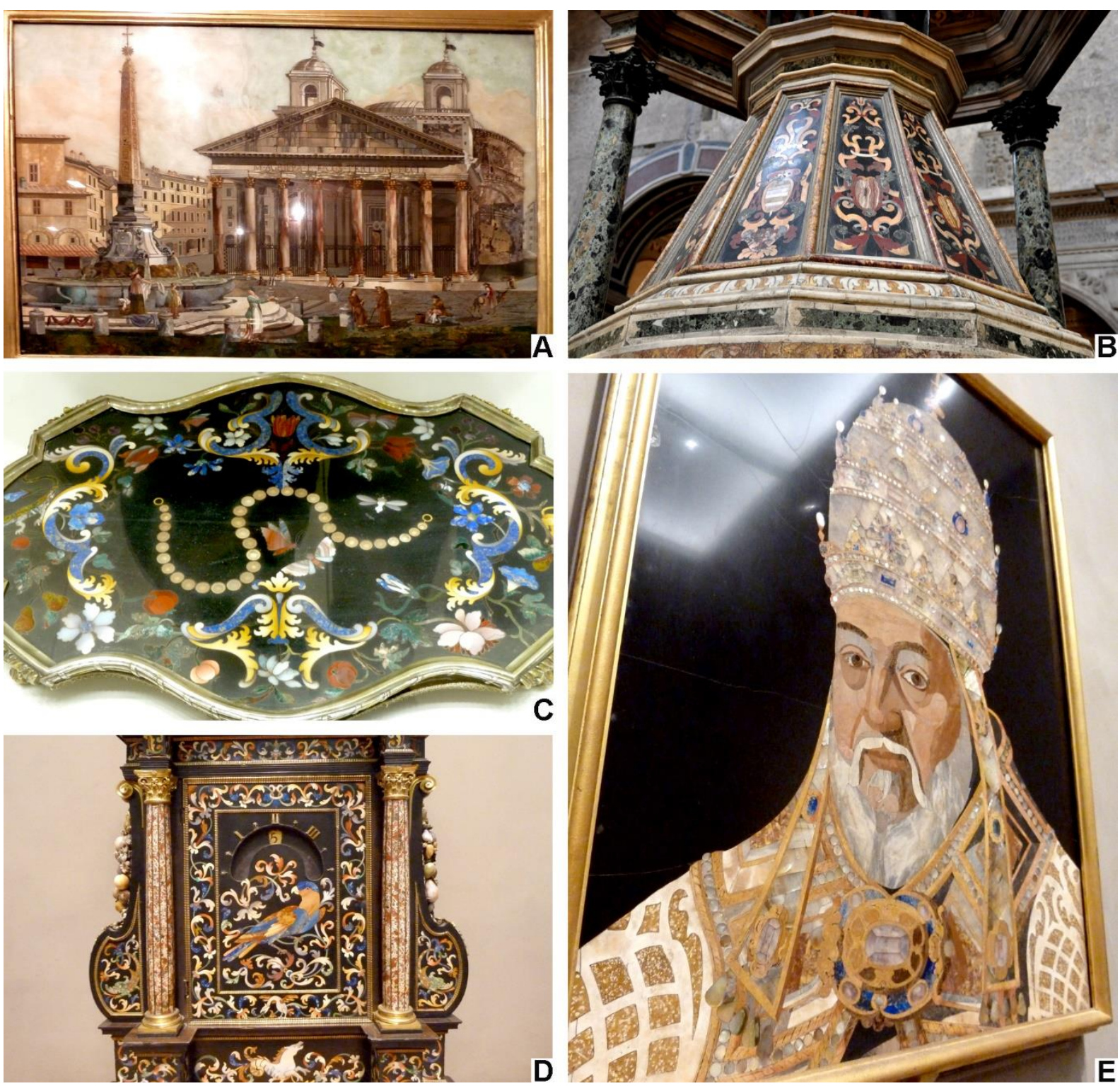

ure, Florença, Itália. B. Basilica di Santa Restituta, Nápoles,

Figura 2.6. Mosaicos Florentinos. A. Opificio delle Pietre Dure, Florença, Itália. B. Basilica di Santa Restituta, Nápoles,
Itália. C. Bandeja da Coleção de Prata, Hofburg, Viena, Áustria. D e E. Instituto Paul Getty, Los Angeles, Estados Unidos.

Apesar dessa variedade pétrea, o travertino é a mais emblemática das pedras romanas, usada desde o século II a.C., sendo até hoje explorada e utilizada.

Amostras destas pedras podem ser visualizadas nas coleções formadas no século XIX. Das 15 coleções citadas por Giampaolo et al. (2008), 8 estão em Roma. Entretanto, a mais importante é a Coleção Corsi, alojada no Museu de História Natural de Oxford (Grã-Bretanha) e disponível para consulta no site: http://www.oum.ox.ac.uk/corsi/.

A Coleção Corsi foi formada pelo advogado Faustino Corsi (1771-1845) entre 1800 e 1827. É constituída por 1.000 amostras no formato de $15 \times 7,5 \times 4 \mathrm{~cm}$, sendo que $50 \%$ são de rochas carbonáticas. Cerca de mais de 300 amostras são do mesmo tipo das usadas na Roma antiga, sendo que as demais foram lavradas após o Renascimento (Cooke 2010). 


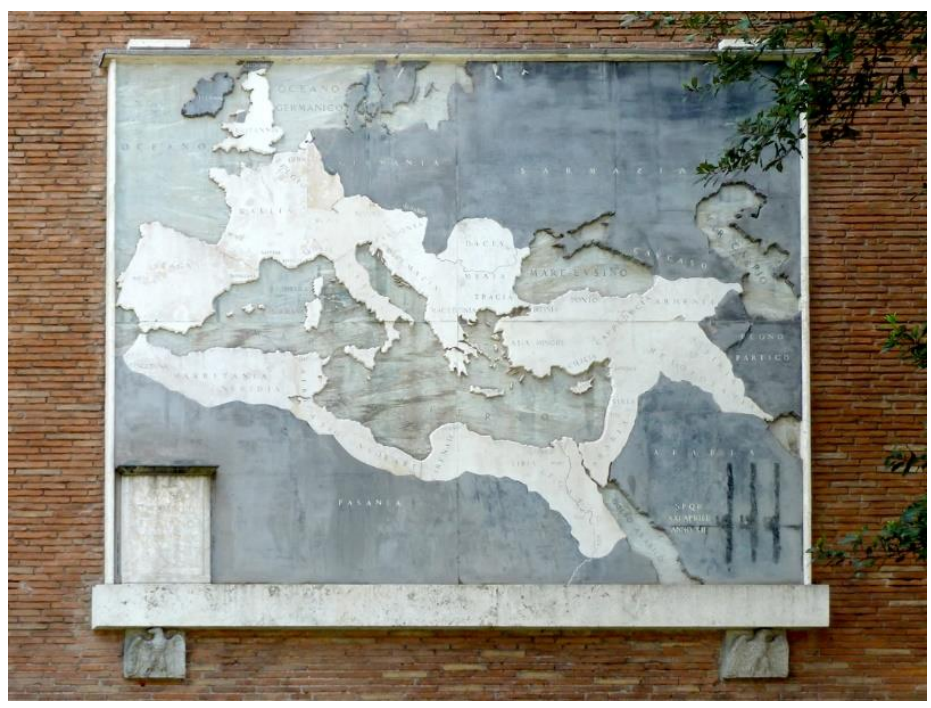

Figura 2.7. Quadro da região do Mediterrâneo sob o domínio romano, Roma, Itália.

As pedras ornamentais utilizadas pelo império romano eram conhecidas como marmi antichi. Apesar do nome mármore, o termo não era usado apenas para rochas carbonáticas metamórficas, e sim para todos os litotipos. Eram pedras extraídas durante a Roma Imperial nas províncias romanas, tais como, Egito, Ásia Menor, Grécia, França, Argélia, Tunísia e também na própria Itália (regiões do Lazio e da Toscana). Descrições dos mármores antigos podem ser encontradas em Borghini (1989), Lazzarini \& Sangati (2004) e Price (2007). Esta última autora também trata de rochas ornamentais modernas e contemporâneas.

Apesar de estarem mais presentes em Roma, os marmi antichi são encontrados em várias localidades em forma de escultura, ornamentação ou revestimento (Figura 2.8).

Durante os séculos XII e XIII, os artesãos da Família Cosmati, aproveitando os marmi antichi das primeiras igrejas ou ruínas de Roma, produziram os geométricos e coloridos pisos cosmatescos, presentes em muitas das igrejas romanas (Figura 2.9), e também na Abadia de Westminster em Londres.

A transformação de Roma da cidade de tijolos para a cidade de mármore ocorreu durante o império.

Com o fim do império (476 d.C.), também aconteceu o declínio de Roma e consequentemente de seus monumentos, e durante o milênio que se seguiu, os antigos monumentos foram dilapidados para a construção de novas edificações (Figura 2.10).

Durante o vasto poderio do império romano, construções com o estilo romano foram feitas em diversos países, sendo que diversas estão ainda preservadas (Figuras 2.11 a 2.13). Os aquedutos são os mais famosos exemplos da engenharia romana e vários teatros estão ainda em uso.

Espanha: em 218 a.C. inicia-se o processo que levou à romanização da Península lbérica. Há ruínas romanas em Empúries (a cidade romana foi construída no século I a.C. ao lado da já 
existente cidade grega), Itálica (fundada em 206 a.C., foi o primeiro assentamento permanente de romanos no sul da península, local de nascimento dos imperadores Trajano e Adriano), Mérida (fundada em 25 a.C., foi a capital da Lusitânia), e Segóvia (com seu aqueduto construído entre os séculos I e II d.C.).
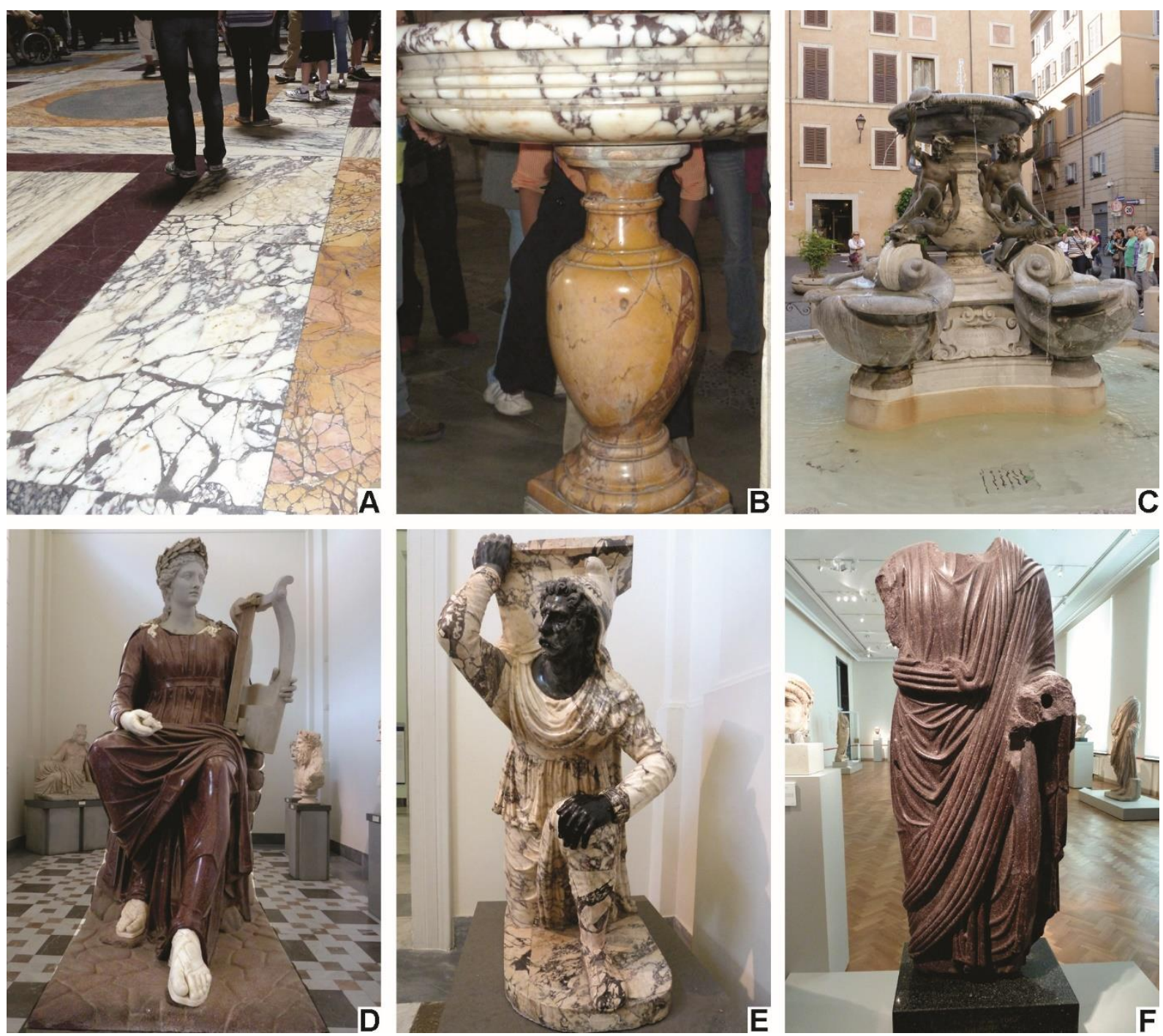

Figura 2.8. Exemplos dos marmi antichi. A. Porfido Rosso Antico (Egito), Pavonazzetto (Ásia Menor), Giallo Antico (Tunísia) e Granito del Foro (Egito) no piso do Pantheon. B. Pia batismal de Pavonazzetto e pedestal de Giallo Antico, Igreja Santa Maria in Aracoeli. C. Bacias de Africano (Ásia Menor) e núcleo de Pavonazzetto, Fontana Monumentale dele Tartarughe. A a C. Roma, Itália. D. Escultura de Porfido Rosso Antico. Notar que o polimento escurece a pedra. E. Escultura de Pavonazzetto e Nero Antico (Tunísia). D e E. Museu Arqueológico de Nápoles, Itália. F. Escultura de Porfido Rosso Antico, Neues Museum, Berlim, Alemanha.

Portugal: a maior presença romana neste país são as ruínas de Conimbriga, cidade que prosperou muito no séc. I, tendo inclusive governo próprio. O Templo Romano em Évora foi praticamente o que sobrou de uma antiga cidade romana.

França: a Pont du Gard, construída no século I a.C., com $48 \mathrm{~m}$ de altura, foi a ponte mais alta construída pelos romanos. Durante os séculos I a.C. a I d.C. há exemplos de construções 
romanas em várias cidades francesas, tais como Grand Théatre e Odeon em Lyon, Templo de Augusto e Lívia em Vienne, Arena de Nîmes, Anfiteatro em Arles, e teatro e arco triunfal em Orange.
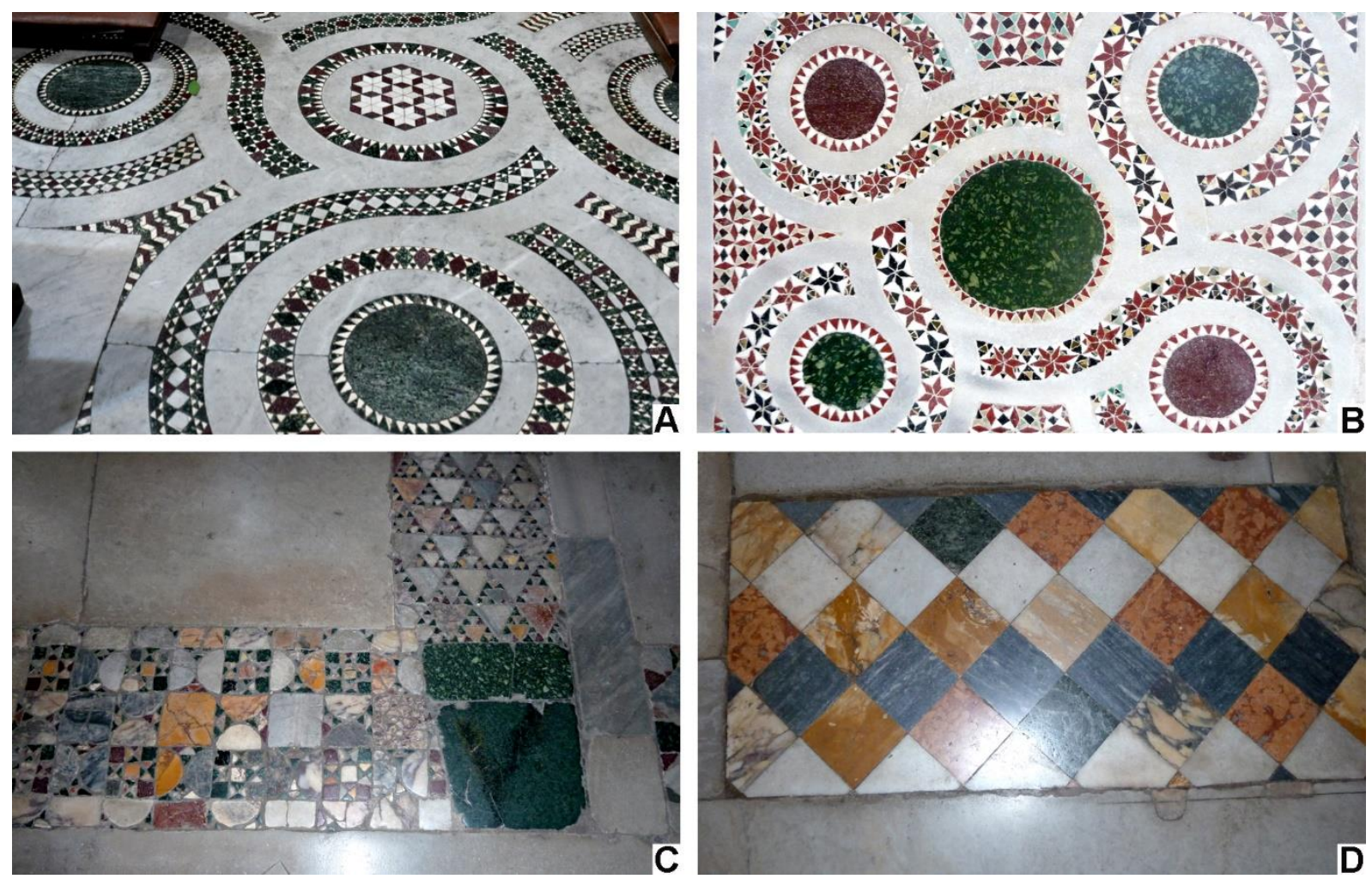

Figura 2.9. Pisos cosmatescos. A. Igreja Santa Maria in Trastevere. B. Fragmento do antigo piso da Basilica del Crocifisso, Amalfi, Itália. C e D. Igreja Santa Maria in Aracoeli. Na nave central há os mosaicos de marmi antichi (C), e nas laterais, pedras modernas (D). A, C e D. Roma, Itália.

Grã-Bretanha: na cidade de Bath há as termas romanas, do século I, tornando o local como o primeiro spa da Inglaterra, fama que foi recuperada no século XVIII. A Muralha de Adriano foi construída pelo imperador homônimo em 120, para se defender dos escoceses do norte.

Jordânia: apesar de Petra ser mais conhecida pelo assentamento humano realizado pelos nabateus, com sua arquitetura e tecnologia hidráulica incomparáveis, também ainda estão preservadas ruínas de edificações construídas na época da ocupação romana, que se deu no ano de 106, quando foi anexada à Província Romana da Arábia. Jarash é considerada uma das mais bem preservadas cidades romanas do Oriente Médio. Em Amman, a ocupação romana pode ser observada no Teatro Romano e o Templo de Hércules.

Turquia: ruínas de Éfeso, a cidade se tornou o principal porto do Mar Egeu sob o domínio romano, sendo que as ruínas das edificações ainda existentes são deste período.

A história de Roma e a pedra estão intrinsicamente relacionadas, não só pelo contexto geológico da cidade, localizada em terreno vulcânico que forneceu o tufo vulcânico para suas construções e a pozzolana para o cimento, direcionando o assentamento urbano e fornecimento de água potável, como o poderio do império que permitiu trazer pedras de todas as suas colônias, tornando a cidade eterna revestida pelos mais diferentes litotipos. 


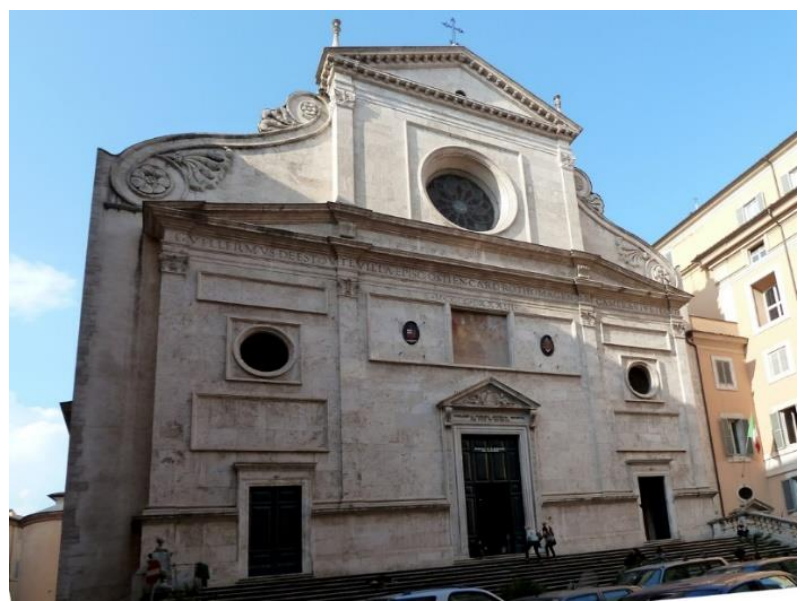

Figura 2.10. Basílica Santo Agostinho, Roma, Itália. Foi construída com material reciclado, utilizando o travertino do Coliseu.
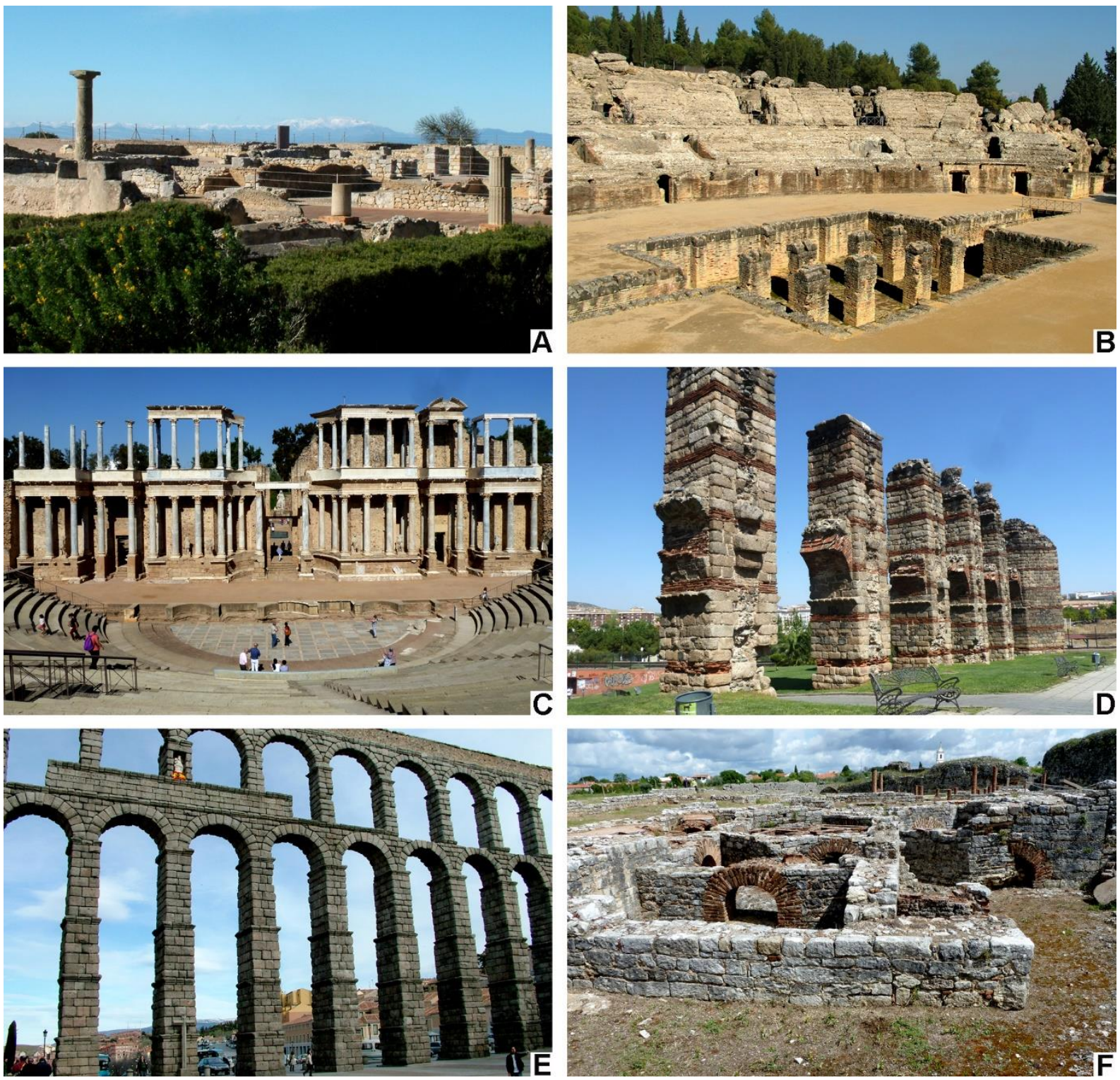

Figura 2.11. Ruínas de construções romanas na Espanha (A a E) e Portugal (F). A. Vista geral de Empúries. B. Anfiteatro em Itálica. C. Teatro de Mérida. D. Aqueduto de Mérida. E. Aqueduto de Segóvia. F. Sítio Arqueológico de Conimbriga. Fotografias A, B e E: Lauro K. Dehira. 

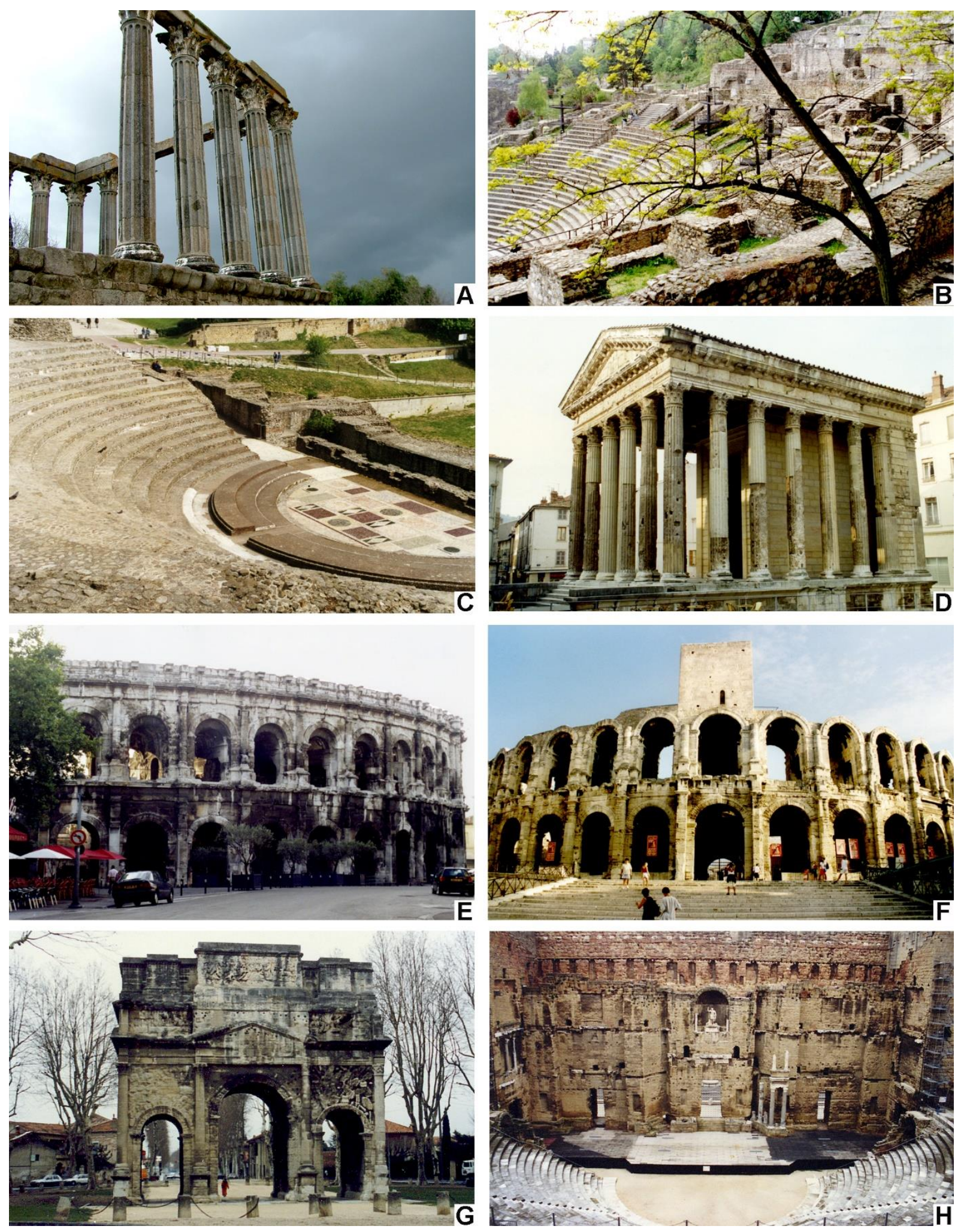

Figura 2.12. Ruínas de construções romanas em Portugal (A) e França (B a H). A. Templo em Évora. B. Grand Théatre em Lyon. C. Odeon em Lyon. D. Templo de Augusto e Lívia em Vienne. E. Arena de Nîmes. F. Anfiteatro em Arles. G. Arco Triunfal em Orange. H. Teatro em Orange. 

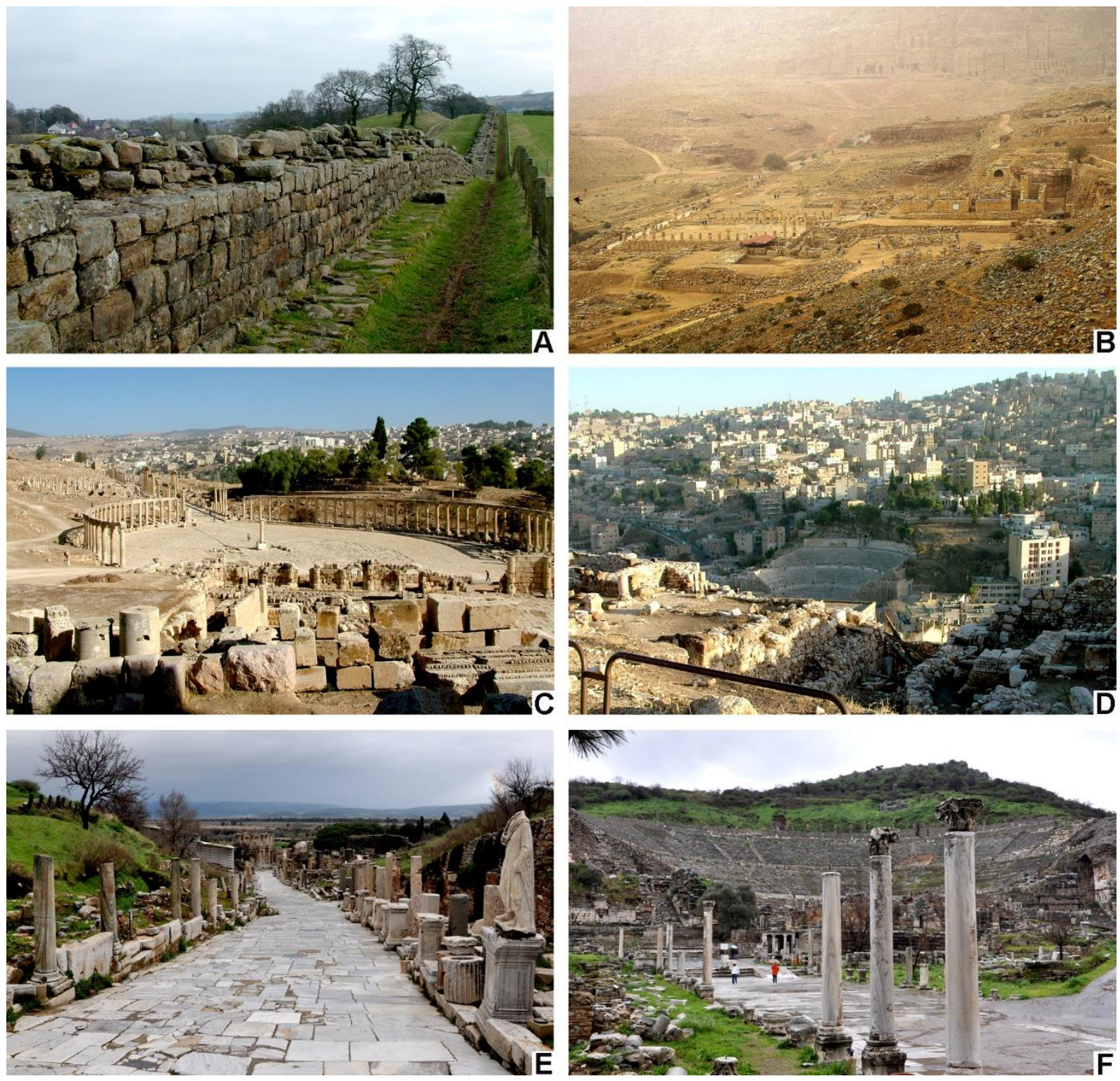

Figura 2.13. Ruínas de construções romanas na Grã-Bretanha (A), Jordânia (B a D) e Turquia (E e F). A. Muralha de Adriano.

B. Sítio Arqueológico de Petra. C. Praça Oval de Jarash. D. Teatro em Amman, vista da Citadela. E. Rua dos Curetes,

Biblioteca de Celso ao fundo, Éfeso. F. Teatro onde o discípulo Paulo pregava para os efésios. Fotografias: Lauro K. Dehira.

\subsection{Exemplos de monumentos em pedra}

Grande parte do patrimônio mundial inscrita da lista da Unesco é constituída de pedra, encontrando-se exemplos dos três grandes grupos: ígneo, sedimentar e metamórfico.

Em algumas localidades há uniformidade e continuidade no uso de determinada pedra, criando um grande vínculo de identificação dos materiais geológicos disponíveis e as construções destes locais, como por exemplo, Salamanca e Arenito Villamayor, Verona e Rosso Verona, Lisboa e Lioz, Edimburgo e Arenito Craigleith.

Em outros locais podem ser caracterizados por mais de um litotipo, como é o caso das igrejas de Florença com as pedras de San Giusto di Monterantoli e Monsummano (marga), Verde di Prato (serpentinito) e Carrara (mármore). 


\subsubsection{Rochas Ígneas}

Entre as rochas ígneas foram utilizadas tanto as plutônicas (granito, granodiorito), como as vulcânicas (basalto, tufo vulcânico), quanto as hipoabissais (diabásio). A mais utilizada foi o granito.

O granito mais velho em exploração no mundo é o Granito de Aswan, no Egito, com mais de 5.000 anos. São desta localidade os inúmeros obeliscos importados por Roma no período augustiano (27 a.C. - 14 d.C.). Atualmente conhece-se apenas a localização de 31 desses obeliscos assim distribuídos: 13 em Roma (incluído o do Vaticano) e 7 no Egito; os demais estão em Florença, Urbino e Catânia (Itália); Paris e Arles (França); Durham, Londres e Wirnborne (Inglaterra); Istambul (Turquia); Cesarea (Israel) e Nova York (Estados Unidos) (Giampaolo et al. 2008). Heiken et al. (2005) afirmam que foram 56 obeliscos trazidos do Egito. Alguns dos obeliscos que estão em Roma, encomendados pela nobreza, são cópias de obeliscos egípcios (Figuras 2.14 e 2.15).
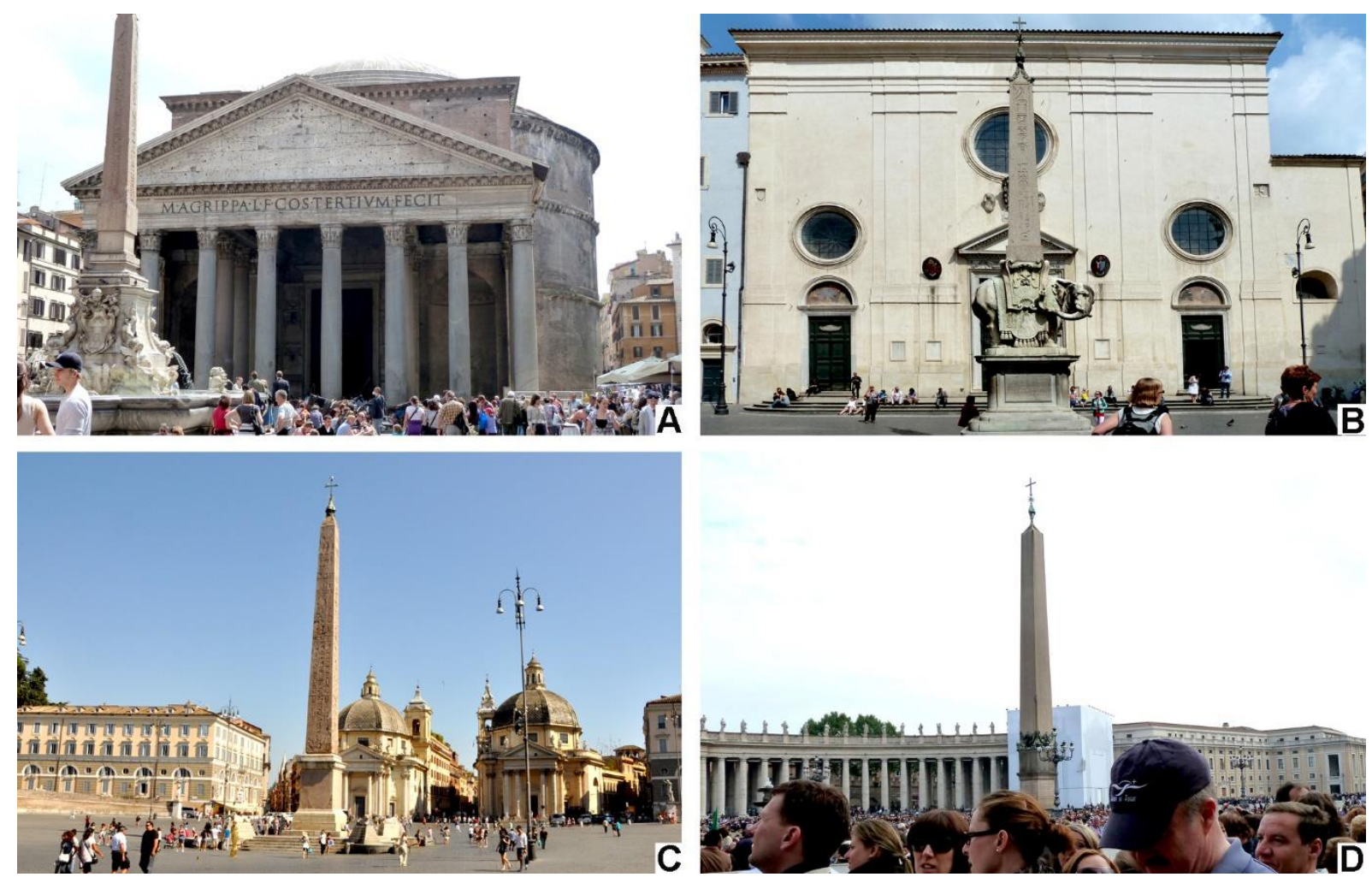

Figura 2.14. Obeliscos egípcios em Roma. A.Obelisco egípcio na Piazza della Rotonda, em frente ao Pantheon. B. Obelisco egípcio na Piazza della Minerva, na lateral do Pantheon. C. Obelisco egípcio na Piazza del Popolo. Este obelisco juntamente com o que está na Piazza di San Giovanni in Laterano localizavam-se anteriormente no Circus Maximus. D. Obelisco egípcio na Piazza San Pietro (diferentemente dos demais não apresenta hieróglifos).

Os obeliscos egípcios são também conhecidos como Agulhas de Cleópatra. O que está em Nova York apresenta a face sul bastante intemperizada, devido a um incêndio que ocorreu em Alexandria, quando ainda estava no Egito (Wheeler 2012) (Figura 2.16). O de Londres apresenta depressões oriundas de marcas de tiros de canhão. 

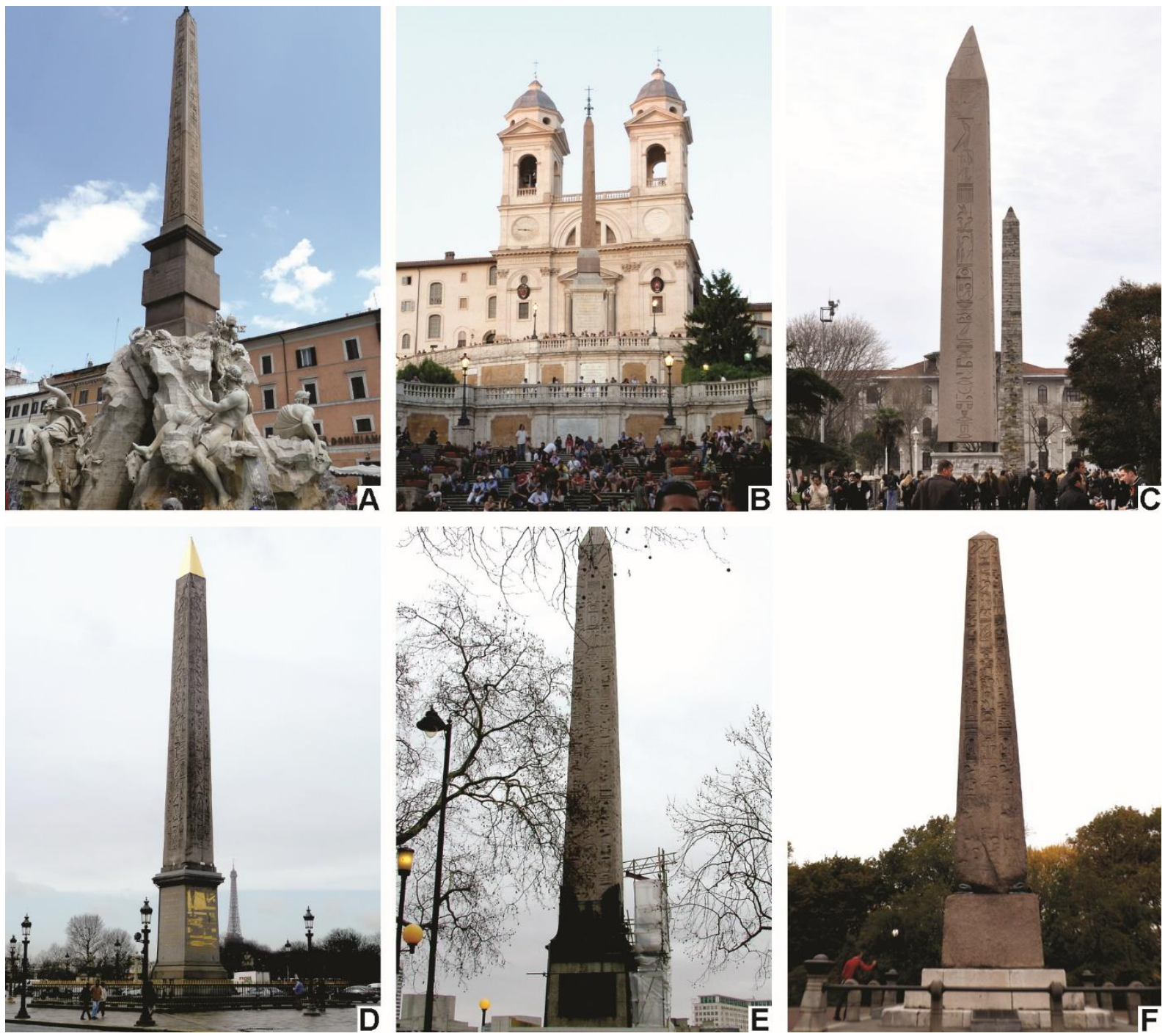

Figura 2.15. Obeliscos egípcios e romanos em Roma (A e B) e alhures (C a F). A. Cópia de obelisco egípcio na Piazza Navona. B. Cópia de obelisco egípcio na Plazza dela Trinità dei Monti. C. Obelisco egípcio no Hipódromo, Istambul, Turquia. D. Obelisco egípcio na Place de la Concorde, Paris, França. E. Obelisco egípcio em Londres, Grã-Bretanha. F. Obelisco egípcio no Central Park, Nova York, Estados Unidos.

Um dos maiores monumentos construídos em uma peça única de granito, o inacabado Templo Vettuvan Koil (que significa paraíso dos escultores), localiza-se em Kalugumadai, na Índia. Outro destaque indiano é a cidade de Mamallapuram, também conhecida como Mahabalipuram, o maior centro de esculturas em granito. O tsunami no Oceano Índico em 2004 expôs a escultura de um leão, o relevo de um elefante e ruínas de uma antiga cidade.

Como outros exemplos de patrimônio construído em granito podem ser citados as estátuas antigas de Buda no Sri-Lanka, o Templo Romano em Évora (Figura 2.12A), a Sé do Porto, o sítio Escorial na Espanha, o Aqueduto de Segóvia (Figura 2.11E), a Tower Bridge em Londres. Monumento mais recente em granito são as cabeças dos primeiros presidentes americanos esculpidas no Mount Rushmore, nos Estados Unidos, moldadas com uso de explosivos. 

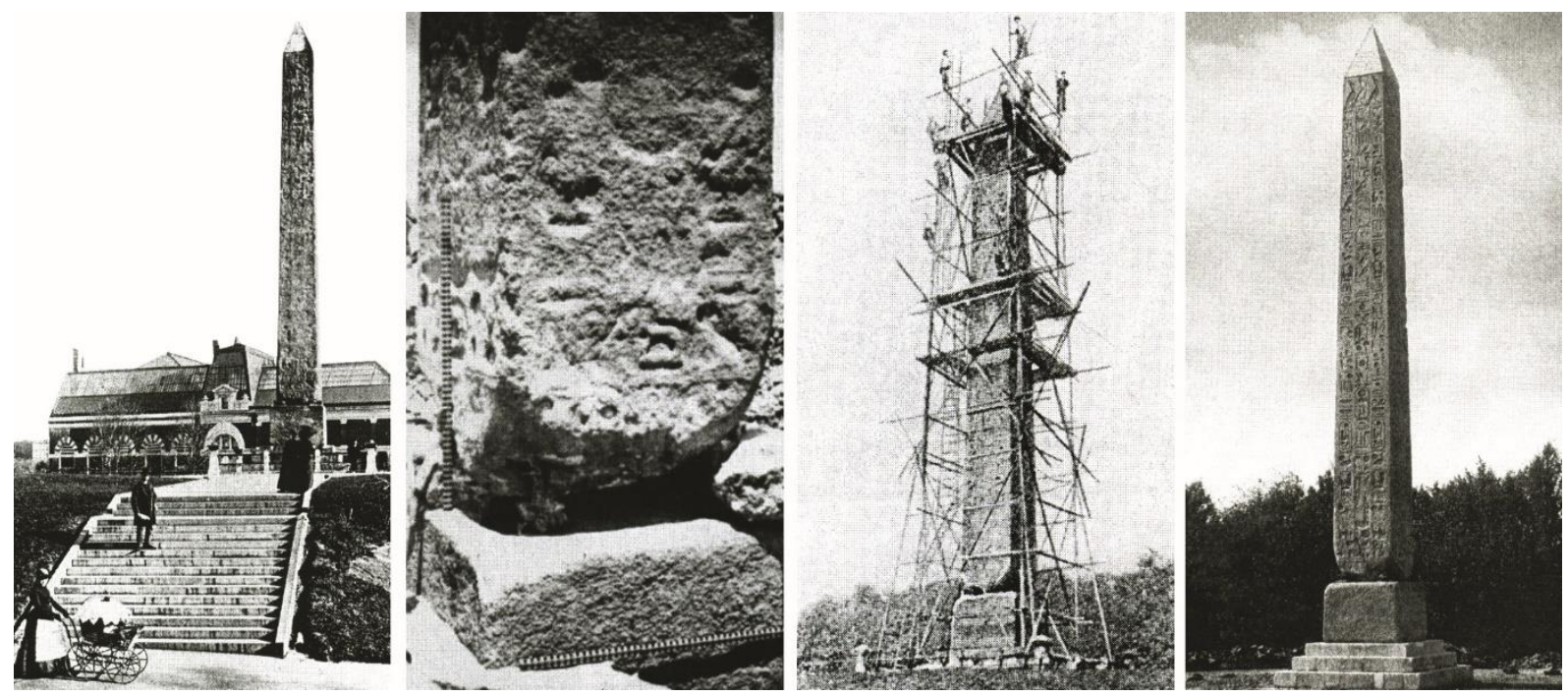

Figura 2.16. Figuras da época de implantação do obelisco egípcio no Central Park em Nova York nos anos 1890. Fonte: Wheeler (2012).

Após a percepção da inadequabilidade de utilização do Calcário de Anston no Parlamento de Londres, foi oferecido, gratuitamente, granito suficiente para reconstruir a edificação, mas que foi recusado devido à dificuldade em trabalhar esta pedra e adequar ao design já existente (Schaffer 1932).

A Pedra de Roseta, um monolito com um decreto inscrito que ajudou na compreensão dos hieróglifos egípcios, é constituída por granodiorito oriundo de Aswan (Figura 2.17A).

A saída do Museu do Vaticano, conhecido como Dedal, é revestida com anortosito (Figuras 2.17B e C).

Um diorito sueco, conhecido como Granito Ébano Preto (Ebony Black Granite), foi usado na fachada inferior do edifício Empire State em Nova York (Dimes 1990a).

O basalto, apesar de ser a rocha vulcânica mais abundante da crosta, não é muito usado como revestimento devido ao alto nível de fraturamento presente em seus afloramentos, o que inviabiliza a obtenção de grandes placas. Desta forma, ele é mais adequado para peças pequenas, como esculturas ou como pavimento, como pode ser observado na Via Ápia (Figuras 2.17D e E). O Código de Hammurabi (1.792-1.750 a.C.) foi inscrito em um monólito de basalto (Figura 2.17F). Entretanto, há exceções como o Templo Kailasa em Ellora, na Índia; e na Jordânia, diferentemente dos outros castelos do deserto, o Qasr Al-Azraq foi construído com basalto (Figura 2.18A). Atualmente o basalto é muito usado em calçamentos no formato de pedra portuguesa, dividindo esta utilização com os calcários pretos.

Os moais da llha de Páscoa foram esculpidos em tufo vulcânico e o chapéu em escória (Figuras 2.18B a E).

A Muralha de Adriano é composta predominantemente por blocos de diabásio (Figura 2.13A). Considerando que a muralha em extensão corta a Grã-Bretanha na direção leste-oeste, a composição petrográfica pode variar de acordo com a disponibilidade pétrea local. 

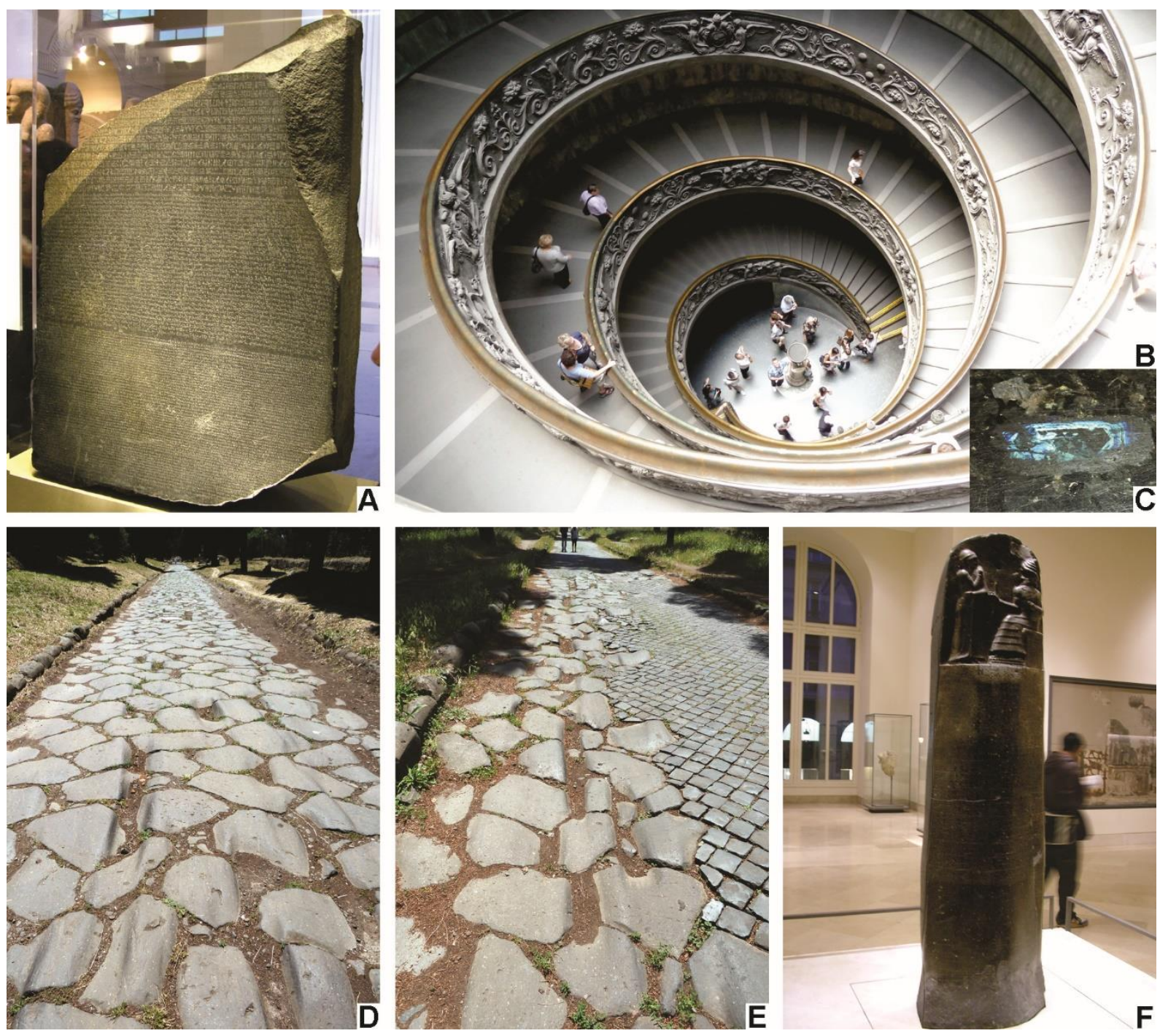

Figura 2.17. Exemplos de patrimônio construídos com rochas ígneas. A. Pedra de Roseta em granodiorito, British Museum, Londres, Grã-Bretanha. B. Dedal, piso da escadaria da saída do Museu do Vaticano em anortosito. C. Detalhe de B, cristal de feldspato centimétrico. D e E. Via Ápia em basalto, notar a marca de roda. Em E a parte da direita foi reconstruída com blocos menores de basalto. F. Código de Hammurabi em basalto, Museu do Louvre, Paris, França

\subsubsection{Rochas Sedimentares}

Entre as rochas sedimentares, as mais comuns utilizadas no patrimônio são os arenitos e os calcários, representando assim rochas clásticas e químicas, respectivamente. São pedras muito utilizadas no patrimônio mundial. Conhecidos pela técnica na arte escultórica, os Maias utilizaram indistintamente arenitos e calcários em suas esculturas (Figuras 2.19A e B).

O arenito é um dos materiais geológicos mais comum, sendo utilizado desde o Neolítico, como mostram as estruturas de pedra em Skara Brae e Maeshowe, na Escócia. Apesar de não ser tão fácil de trabalhar como o calcário, tem a vantagem de apresentar grande diversidade de cores e texturas, além da estratificação, quase sempre presente, facilitar sua extração. Exemplos de patrimônio pétreo construído em arenito podem ser citados: Stonehenge (as grandes sarsen stones foram feitas de um arenito local, as menores bluestones do círculo interno foram feitas de uma variedade de rochas ígneas encontradas no Preseli Mountains no 
sul do País de Gales), o Templo de Luxor no Egito, a cidade de Petra na Jordânia (Figuras 2.1A e 2.13B), Angkor Wat no Camboja, os templos indianos, a Ponte Carlos na República Tcheca (Figura 2.19C), Portão de Brandenburgo (Figura 2.19D) em Berlim (arenito proveniente da região de Dresden e Magdeburg), Casa Branca em Washington D.C. (arenito de Aquia Creek, Virgínia), entre inúmeros outros exemplos.
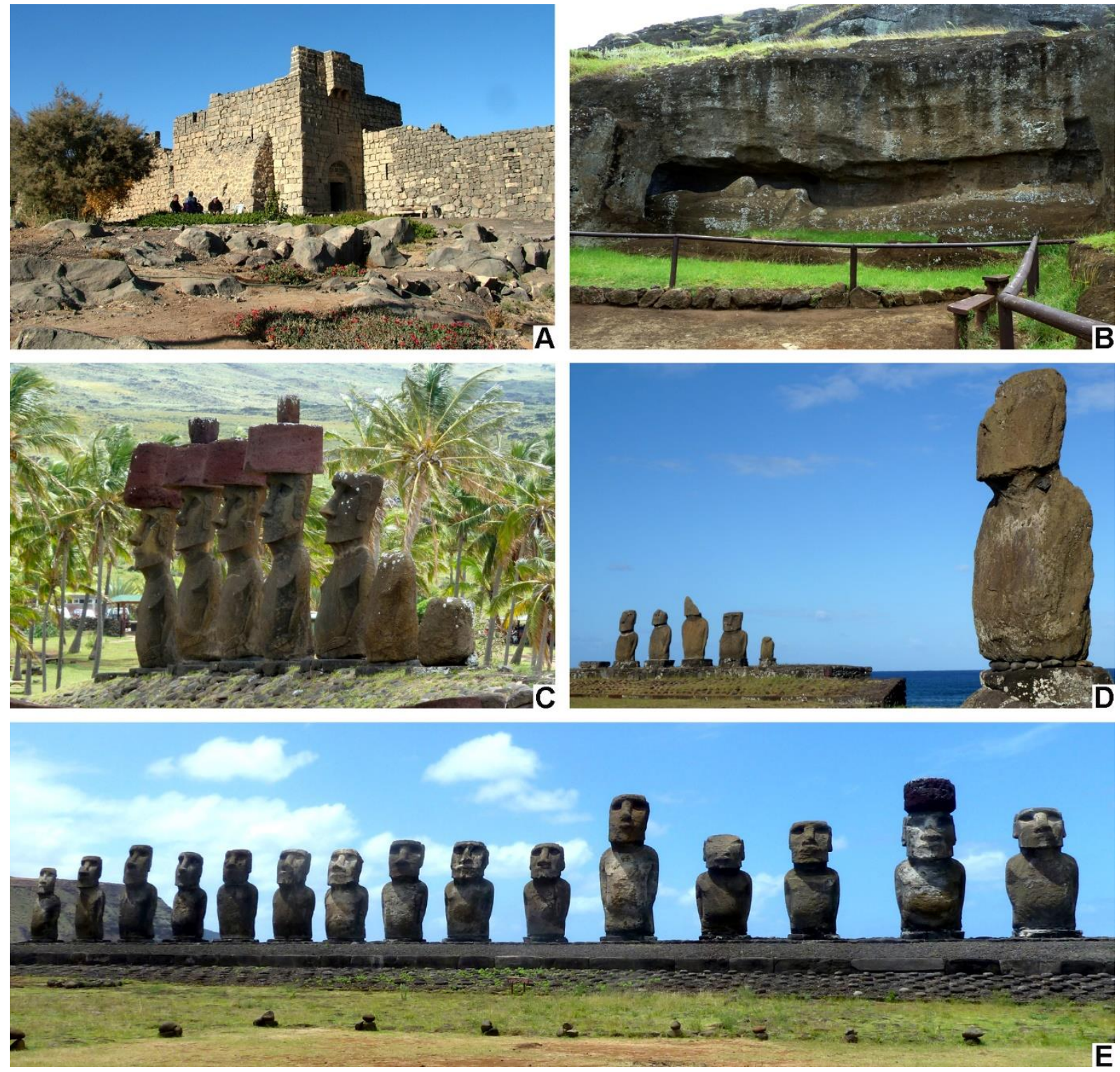

Figura 2.18. Exemplos de patrimônio construídos com rochas ígneas. A. Qasr Al-Azraq em basalto, castelo do deserto na Jordânia, utilizado por Lawrence da Arábia na revolta árabe. B a E. Moais em tufo vulcânico na Ilha de Páscoa, Chile. B. Moai inacabado na pedreira de origem. C. Ahu Nau Nau, alguns moais têm pukao (chapéu) confeccionado com escória vermelha. D. Ahu Vai Uri à esquerda e Ahu Tahai à direita. E. Ahu Tongariki.

Até a metade do século XIX, quase todos os edifícios da Escócia eram de arenito (Dimes 1990b). Em Edimburgo, apesar da predominância do Arenito Craigleith, o Old Red Sandstone também foi utilizado nas construções, de idades carbonífera e devoniana, respectivamente. O Arenito Craigleith não é mais explorado atualmente e, dentre os monumentos construídos 
com esta pedra estão o Castelo de Edimburgo (Figura 2.19E) e o Monumento Nacional da Escócia (Figura 2.19F). Em Londres, que não usou muito arenito em seus monumentos, o Arenito Craigleith pode ser observado na estátua de Nelson (somente a estátua é de arenito, a coluna é de Granito Foggintor) e no piso e escadaria do British Museum.

Com menor expressão ocorrem conglomerados e brechas. Na Turquia, estas pedras foram utilizadas como colunas em Istambul, Troia e Éfeso, com destaque para o Verde Antico nas 48 colunas de Santa Sofia (Figura 2.20A). Na Espanha são observadas na região da Andaluzia e no Mosteiro de Monte Serrat (Figuras 2.20B a D). Em Portugal há a Brecha da Arrábida (Figura 2.20E), que atualmente não é mais explorada. $\mathrm{Na}$ maior parte das construções de Salzburgo foi usado um conglomerado, não só como blocos e placas, mas também há construções escavadas no próprio maciço rochoso.

Apesar de grande parte do território do Egito estar assentada sobre calcário e esta ter sido a pedra utilizada na construção das grandes pirâmides, outros litotipos foram utilizados nos monumentos egípcios. Klemm \& Klemm (2001) descrevem os onze tipos de pedra mais populares usadas no Egito Antigo.

Na Europa, o calcário pode ser considerado quase que como uma pedra religiosa, já que foi muito utilizado em vários edifícios eclesiásticos, tais como: Igreja Notre Dame de Paris (construída com calcário da região de St. Jacques, sendo as catacumbas antigas pedreiras), Catedral Gótica de Chartres, Mosteiro da Batalha (calcário oolítico), Catedral de St. Paul em Londres (Calcário Portland, muito popular em algumas partes da Inglaterra, sendo usado também no Museu Ashmolean em Oxford), Catedral de Wells (Calcário Doulting) e Catedral de York (calcário magnesiano), entre outras.

O Calcário Lioz, pedra portuguesa da região de Lisboa, está presente em muitos edifícios eclesiásticos, tais como: Sé de Lisboa, Mosteiro dos Jerónimos (Figura 2.20F), Basílica da Estrela, Mosteiro de Alcobaça, Convento de Mafra (Figura 2.20G), e outros monumentos nacionais, como a Torre de Belém e o Palácio da Ajuda.

Aires-Barros (2001) descreve as pedras dos monumentos portugueses, abordando seus litotipos e suas patologias, e IPPAR (2006) aborda especificamente a conservação do claustro do Mosteiro dos Jerónimos.

O travertino (Figura 2.21) é uma rocha calcária depositada por águas termais. Os principais depósitos para exploração como pedra ornamental estão localizados em Tívoli (Itália) e Pamukkale (Turquia). Esta pedra foi denominada Lapis Tiburtinus (do latim: pedra de Tibur) pelos romanos, porque era encontrada em grande quantidade em Tibur, próximo à Roma, e hoje denominada Tívoli, ainda grande centro produtor de travertino.

Em Roma há muitos exemplos de monumentos construídos com travertino, tais como: o Coliseu, a Fonte dos Rios na Praça Navona, as paredes do canal do Rio Tibre, e também as colunas da Praça São Pedro no Vaticano. Exemplos contemporâneos são encontrados no Templo da Sagrada Família em Barcelona e no Instituto Getty em Los Angeles.

$\mathrm{Na}$ Hungria também há exploração de travertino, sendo as pedreiras concentradas na região de Budapeste, mas os monumentos constituídos por esta pedra estão espalhados por todo o país. Atualmente, no Parlamento de Budapeste, que foi construído com calcário oolítico, está sendo substituído por um travertino (Přikryl \& Török 2010). 
As civilizações que viveram na região do Mediterrâneo fizeram uso intenso de rochas carbonáticas, sendo utilizadas sucessivamente pelos etruscos, fenícios, gregos, romanos, habitantes da costa mediterrânea, até chegar aos dias atuais, sendo ainda hoje uma importante região de produção de rochas carbonáticas para construção (Calvo \& Regueiro 2010) (Figura 2.22).
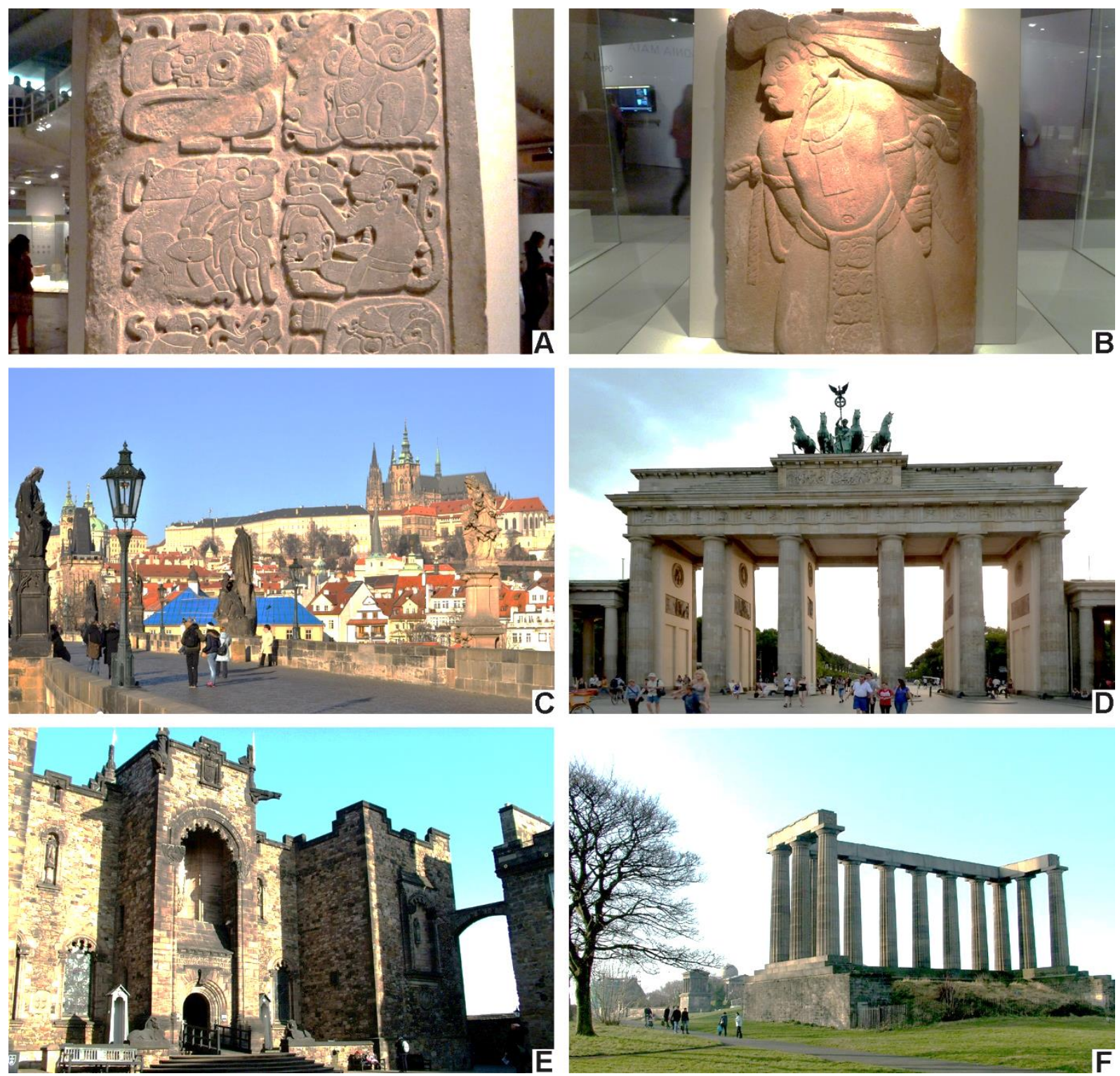

Figura 2.19. Exemplos de patrimônio construídos com rochas sedimentares. A. Escultura maia em calcário. B. Escultura maia em arenito. A e B. Fotografias da exposição Mayas-Revelação de um tempo sem fim na Oca, São Paulo, 10/06 a 24/08/2014, gentilmente autorizadas pela organização. C. Ponte Carlos em arenito, Praga, República Tcheca. D. Portão de Brandenburgo em arenito, Berlim, Alemanha. E. Castelo de Edimburgo, Escócia, em arenito. F. Monumento Nacional da Escócia em arenito, Edimburgo. Fotografias C a F: Lauro K. Dehira. 

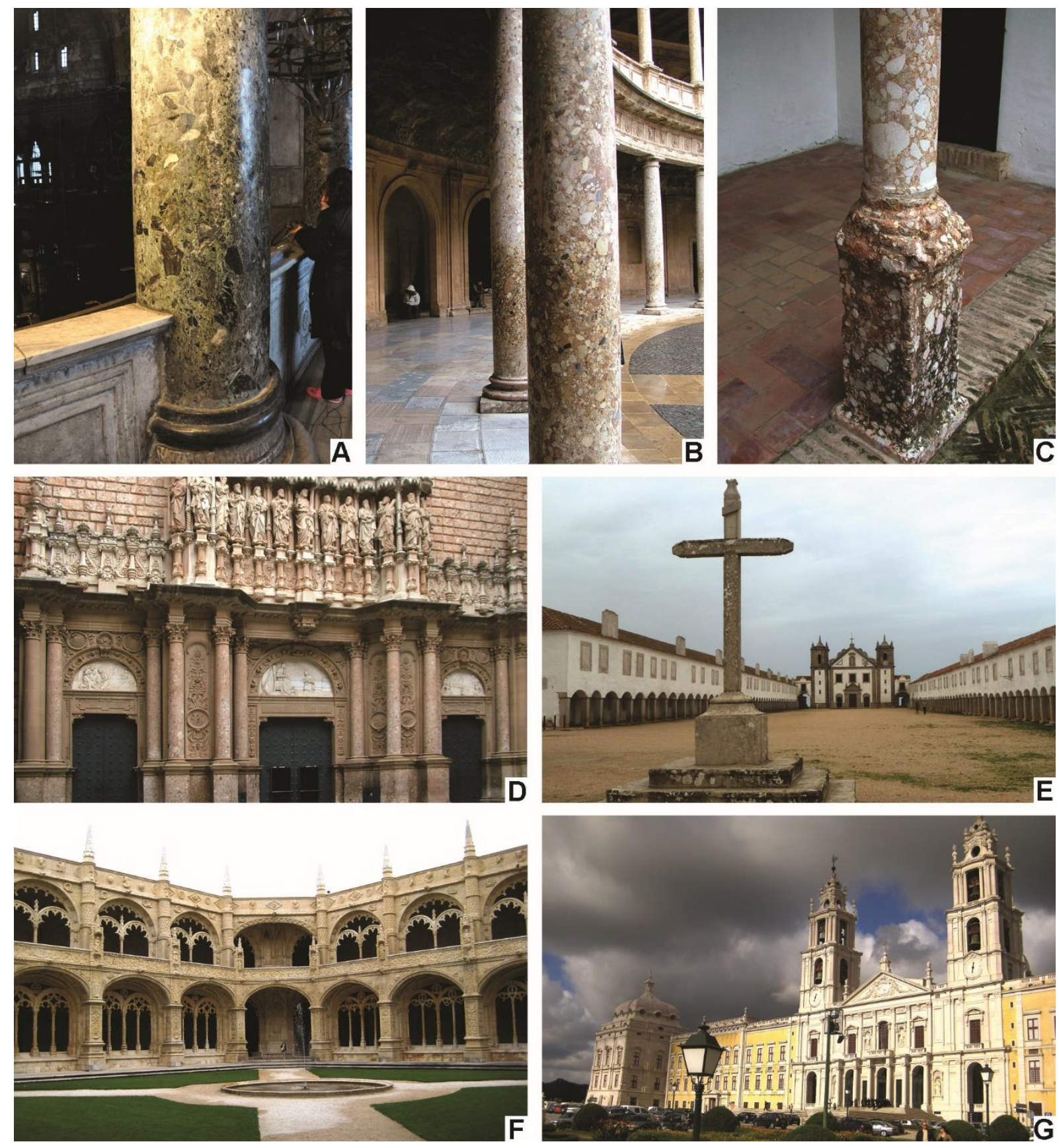

Figura 2.20. Exemplos de patrimônio construídos com rochas sedimentares. A. Colunas de Verde Antico em Santa Sofia, Istambul, Turquia. B. Coluna de conglomerado, Alhambra, Granada, Espanha. C. Coluna de conglomerado no Alcazar de Sevilha, Espanha (notar a erosão mais acentuada da parte inferior da coluna, onde há mais contato com água). D. Mosteiro de Mont Serrat, Espanha, em conglomerado. E. Santuário do Cabo Espichel, Portugal (as paredes internas do santuário são revestidas com a Brecha da Arrábida). F. Claustro do Mosteiro dos Jerónimos em Calcário Lioz, Lisboa, Portugal. G. Convento de Mafra em Calcário Lioz, Portugal. Fotografias D: Lauro K. Dehira; F e G: Maria Lúcia Del Lama. 

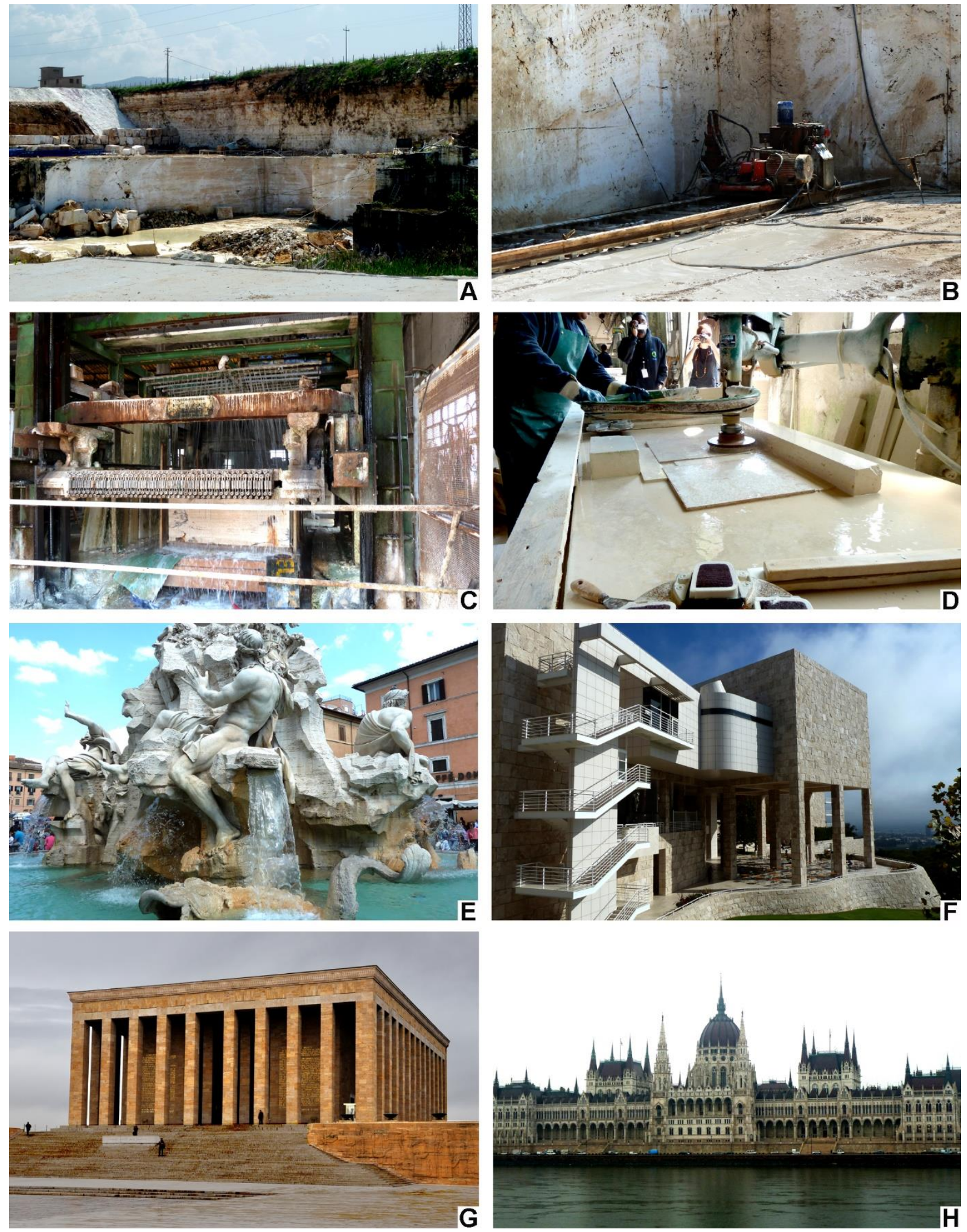

Figura 2.21. Travertino. A a D. A cidade de Tívoli, Itália, foi e ainda é um grande centro produtor e exportador de travertino. E e F. Uso antigo e contemporâneo do travertino romano. E. Fontana dei Quattro Fiumi, Piazza Navona, Roma, Itália. F. Instituto Paul Getty, Los Angeles, Estados Unidos. G. Mausoléu de Atatürk, Ancara, Turquia. H. Parlamento de Budapeste, Hungria. 


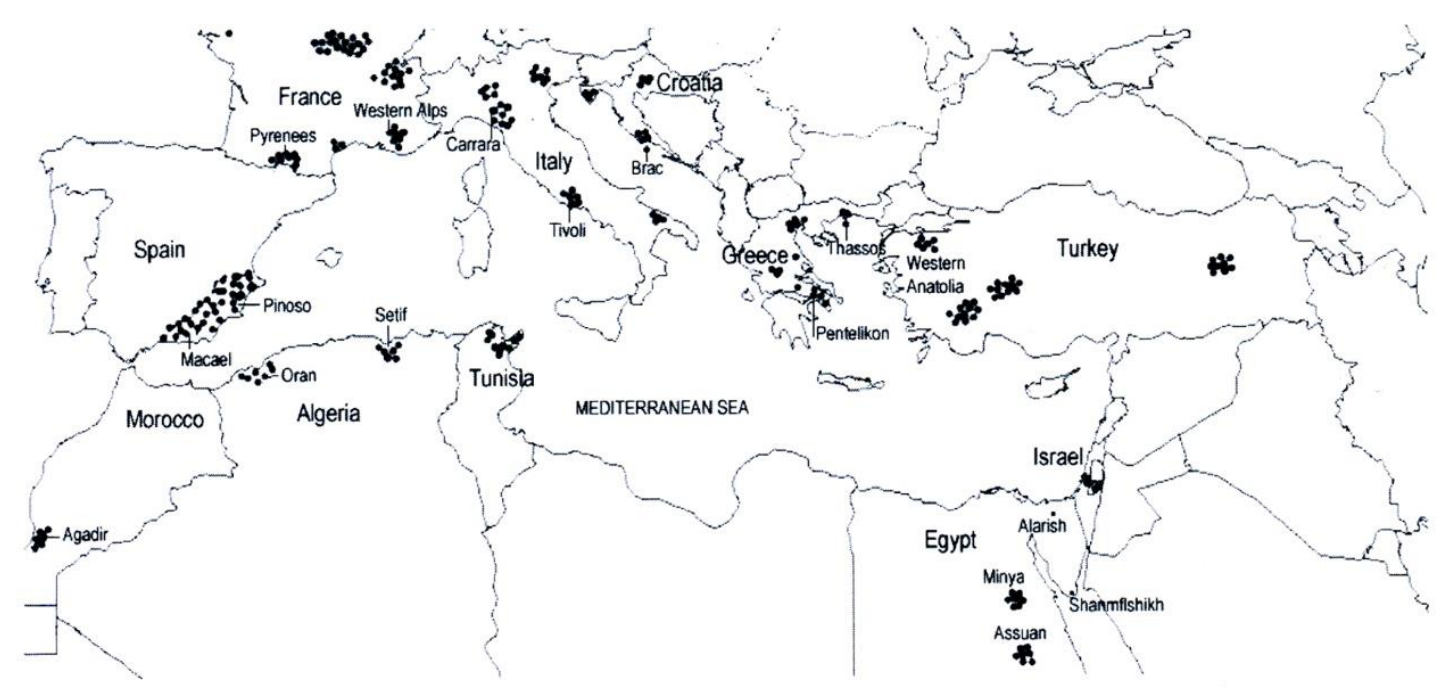

Figura 2.22. Mapa esquemático da região do Mediterrâneo mostrando os principais produtores de rochas carbonáticas. Fonte: Calvo \& Regueiro (2010).

Os evaporitos, se usados em seu ambiente de formação, podem ser utilizados como material de construção (Figura 2.23), e se tornar uma grande atração turística, como as catedrais de sal construídas em minas subterrâneas. A maior delas localiza-se em Wieliczka, Polônia, e a representante sulamericana localiza-se em Zipaquirá, Colômbia.
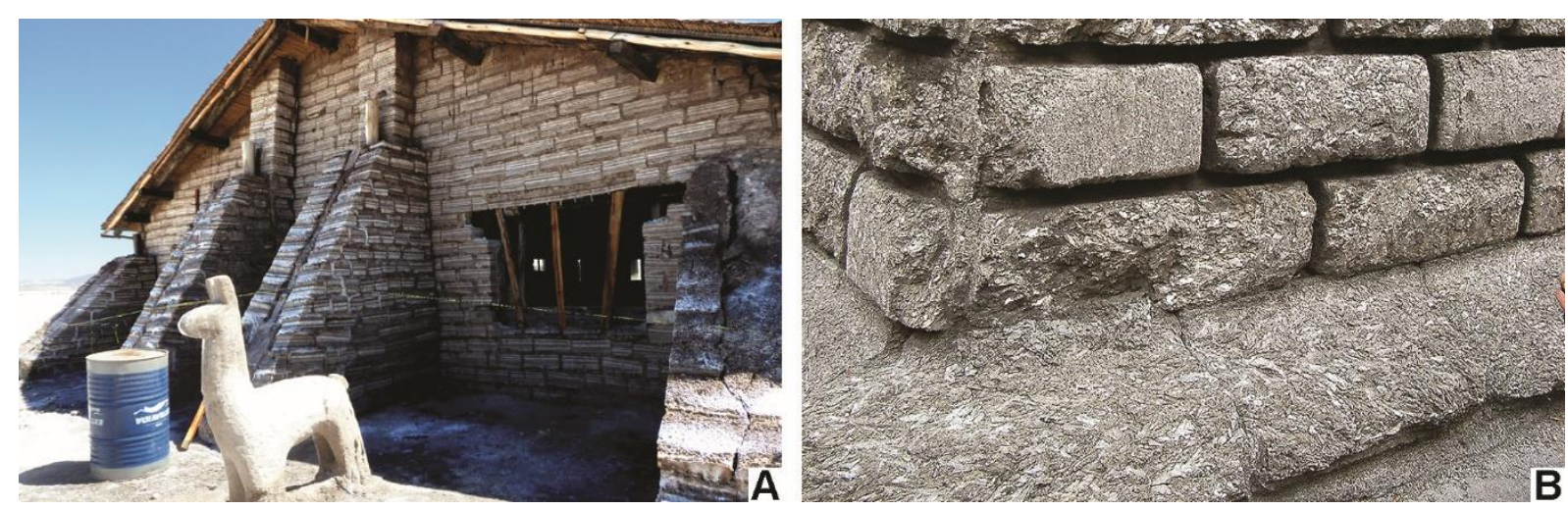

Figura 2.23. Evaporitos. A. Restaurante e escultura de lhama em evaporito em Salinas Grandes, Jujuy, Argentina. B. Torres Inclinadas em Bolonha, Itália. Observar cristais centimétricos de selenita. Fotografia B: José Delgado Rodrigues.

\subsubsection{Rochas Metamórficas}

As rochas metamórficas são amplamente representadas pelo mármore (Figuras 2.24 e 2.25). $\mathrm{Na}$ realidade, o mármore atingiu essa condição de rei das pedras, não tanto pela sua abundância, mas pela sua trabalhabilidade facilitada por sua composição mineral de baixa dureza, o que fez com que fosse extensivamente utilizado.

Michelangelo imortalizou esta pedra com suas esculturas Davi, Pietà e Moisés, tendo trabalhado praticamente apenas com o Mármore Carrara, um dos melhores e mais famosos 
mármores do mundo. Posteriormente Gian Lorenzo Bernini também fez uso intenso de mármore, não só do homogêneo Carrara, como também de mármores texturizados e coloridos, incluindo o Cottanello (calcário vermelho e branco cisalhado e venulado da região do Lazio).

O Cottanello foi explorado em tempos antigos e novamente por Bernini na explosão artística da Roma barroca (Heiken et al. 2005).

Os mármores gregos têm capítulo à parte com os seus mármores brancos clássicos, Pariano e Pentélico, e o colorido mármore Skyros. O Mármore Pentélico foi usado no Parthenon em Atenas e o Mámore Pariano em sua cobertura.

Em Portugal, as maiores explorações de mármore ocorrem no triângulo Estremoz-Borba-Vila Viçosa. Na freguesia de Pardais há a Pedreira Fonte da Moura, uma das mais profundas em exploração, com uma cava de $150 \mathrm{~m}$. O Paço Ducal de Vila Viçosa é revestido com os mármores da região.

Os mármores utilizados no interior do Parlamento de Budapeste vieram da França, Itália, Alemanha e Transilvânia (que na época de sua construção pertencia à Hungria).

Grandes marcos da capital norteamericana foram construídos com mármore, tais como, Memorial Lincoln, cujo projeto foi inspirado no Parthenon, o Monumento a Washington, que foi revestido com 3 tipos diferentes de mármores: Texas, Lee e Cockeysville, cuja diferenciação cromática facilita as suas identificações.
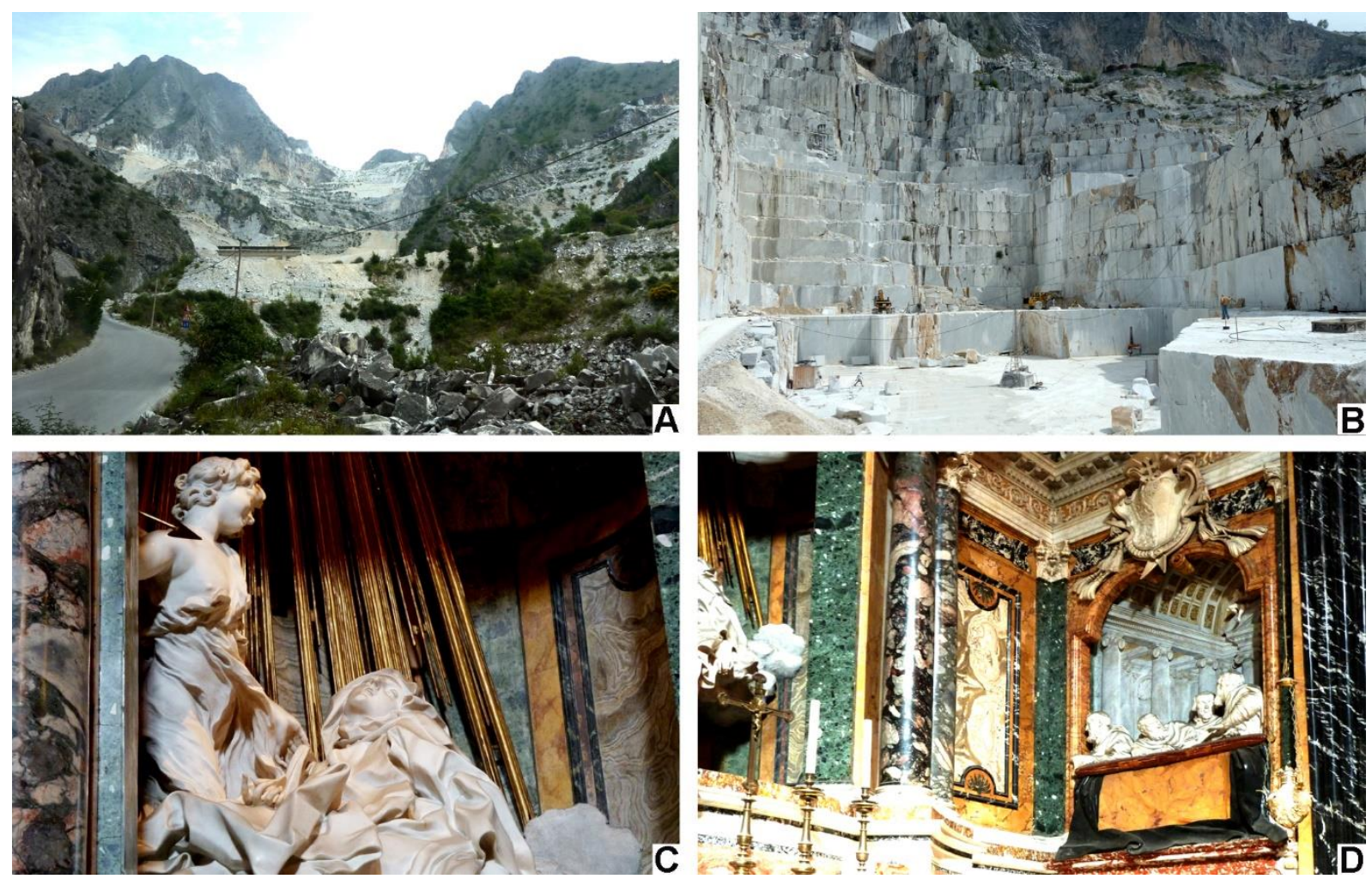

Figura 2.24. Mármore. A. Região de Carrara, Itália, grande produtora de mármore. B. Pedreira em Carrara, Itália. C e D. Êxtase de Santa Teresa, uma das mais importantes esculturas de Bernini, Igreja Santa Maria dela Vittoria, Roma, Itália. Bernini utilizou diferentes litotipos nesta igreja barroca. Em D, notar o Cottanello na parte inferior do camarote. 

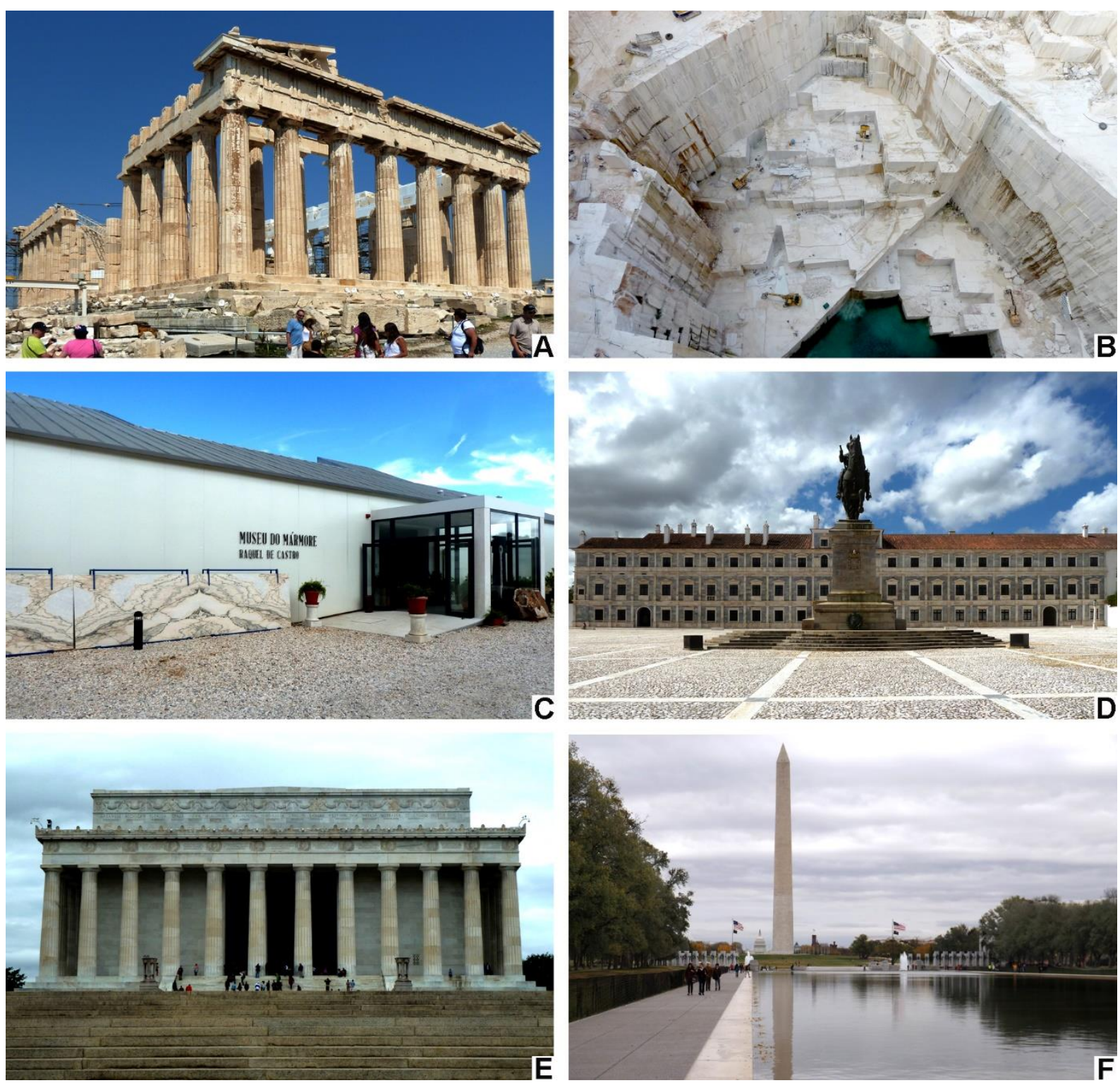

Figura 2.25. Mármore. A. Parthenon, Atenas, Grécia. B. Pedreira Fonte da Moura, Pardais, Portugal, com cava de 150 m. C. Museu do Mármore, indicando a importância do mármore na região. D. Paço Ducal. C e D. Vila Viçosa, Portugal. E. Memorial Lincoln. F. Monumento a Washington. E e F. Washington D.C., Estados Unidos.

Um exemplo de gnaisse é encontrado nos monólitos de Callanish, Escócia, e em esculturas egípcias.

A ardósia é muito utilizada em telhados na Europa, devido à sua facilidade de extração em forma de delgadas placas e por suportar o peso da neve nos invernos rigorosos. Nas áreas onde se extrai a ardósia, as construções apresentam majoritariamente a cobertura com esta pedra, destacando-se na paisagem, como a região de Arouca, Portugal. Foi utilizada na Porta dos Nós do Paço Ducal de Vila Viçosa (Figuras 2.26A e B).

A suevita (pedra formada por impacto da queda de meteorito) foi usada na construção da Igreja de São George em Nördlingen, na Alemanha (Figuras 2.26C a E). Esta cidade tem a 
particularidade de ter sido assentada em uma cratera de impacto, assim como a localidade de Colônia, no sul da cidade de São Paulo, constituindo-se nas duas únicas localidades que ocupam uma cratera de impacto.

Dimes (1990a,b,c) descreve todas as pedras ornamentais (ígneas, sedimentares e metamórficas) utilizadas nas construções da Grã-Bretanha e as importadas que lá chegaram.
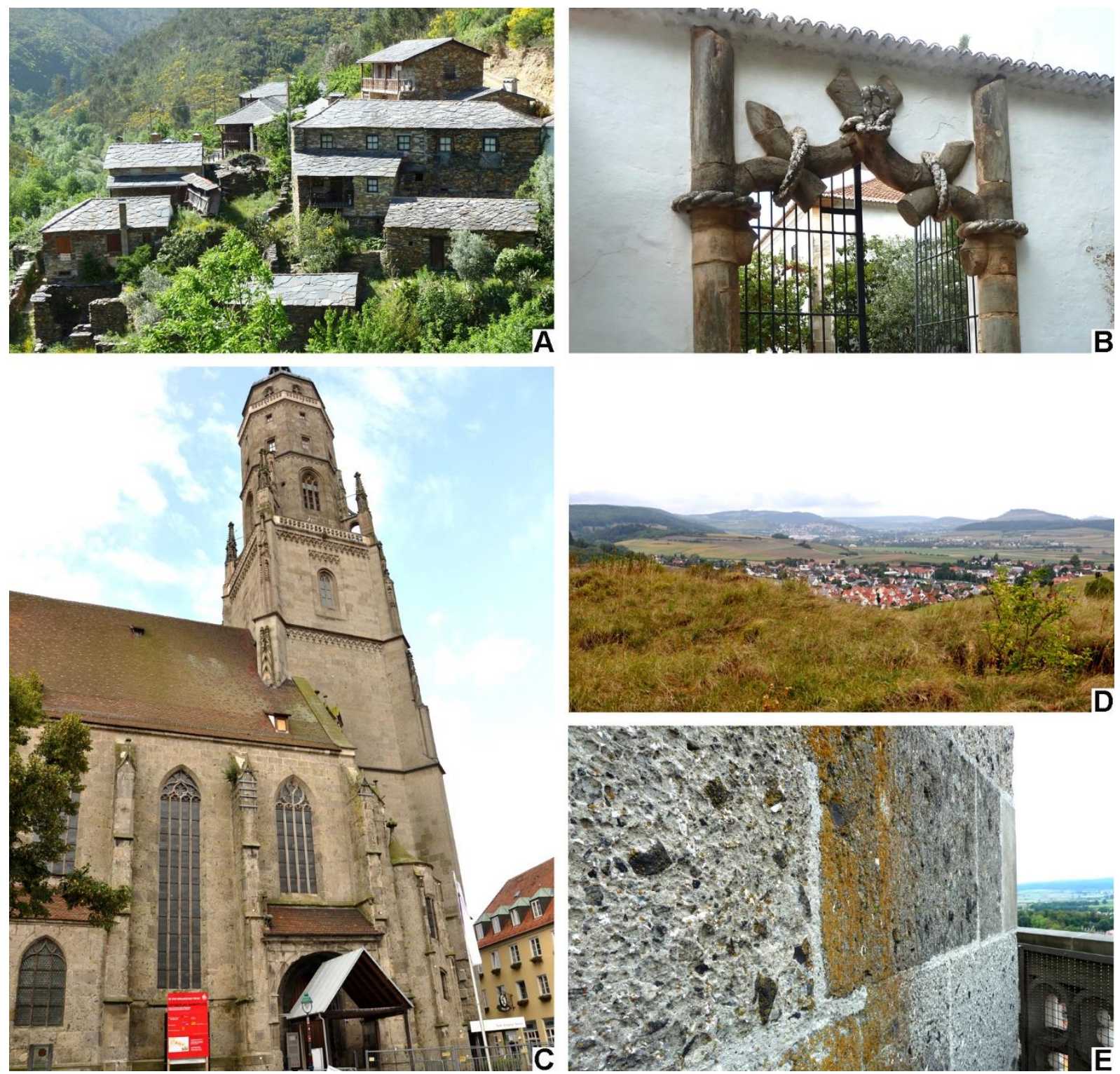

Figura 2.26. A. Região produtora de ardósia, constituindo as telhas de todas as habitações, Aldeia da Paradinha, Portugal. B. Porta dos Nós, mármore e ardósia, Paço Ducal, Vila Viçosa, Portugal. C. Igreja de São George, construída com a incomum suevita. D. A suevita foi formada na cratera de impacto de um meteorito, hoje habitada no seu núcleo. E. Detalhe do revestimento da igreja construída com suevita. $\mathrm{C}$ a E. Nördlingen, Alemanha. 


\subsubsection{Minerais}

E há também uso de minerais em mobília e ornamentação (Figura 2.27). Vale ressaltar que alguns dos marmi antichi são na realidade minerais, tais como gipsita (e sua variedade alabastro), ágata, ametista, jaspe, lápis-lazúli, turquesa, malaquita e fluorita.

O alabastro, por ser translúcido e se tornar uma fonte de luz, foi muito usado em janelas na região do Mediterrâneo, além de usos mais tradicionais como vasos e estátuas. Apesar de sua extração ser realizada em muitos locais, o distrito de Volterra, na Itália, é muito conhecido como local de procedência.
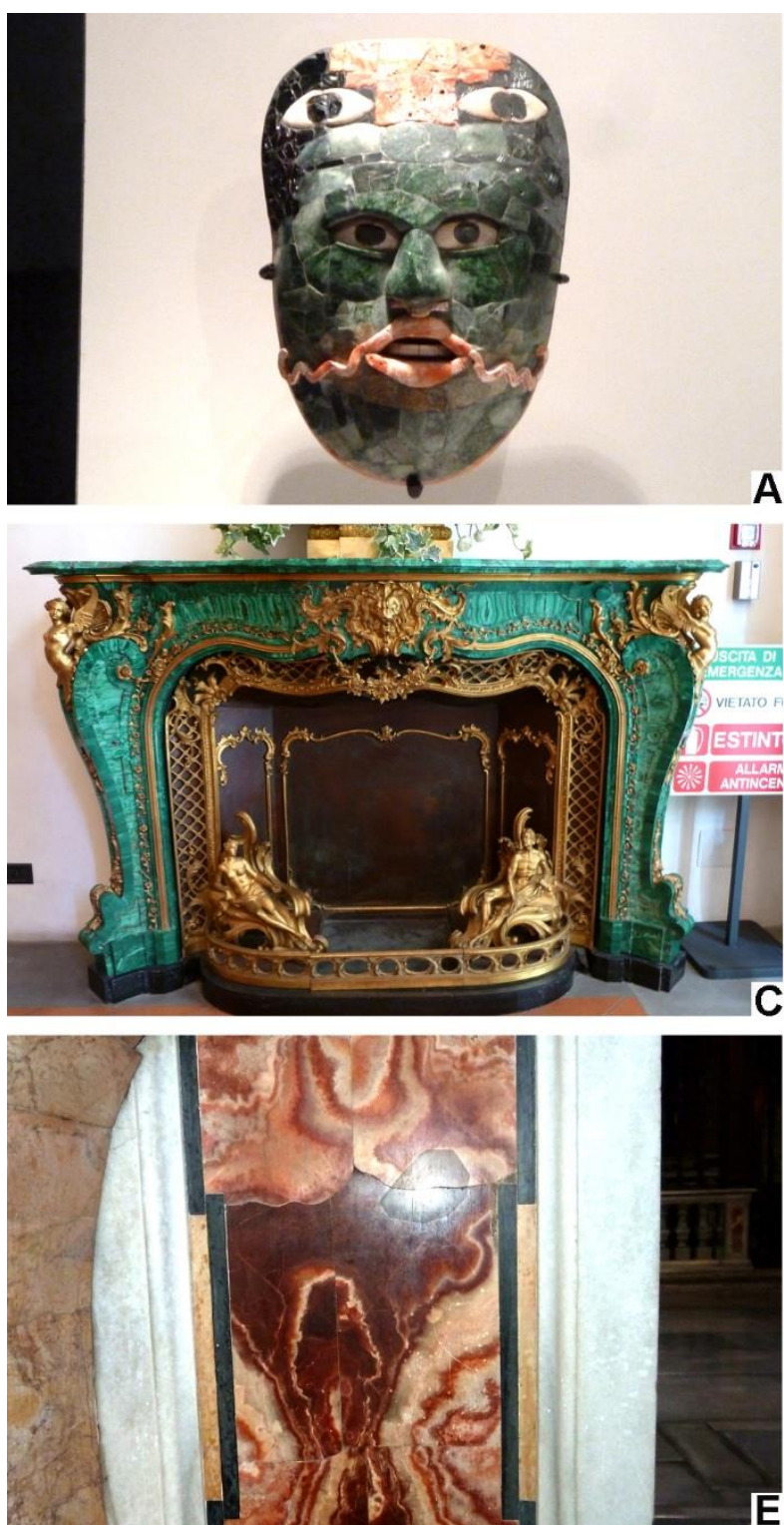

A
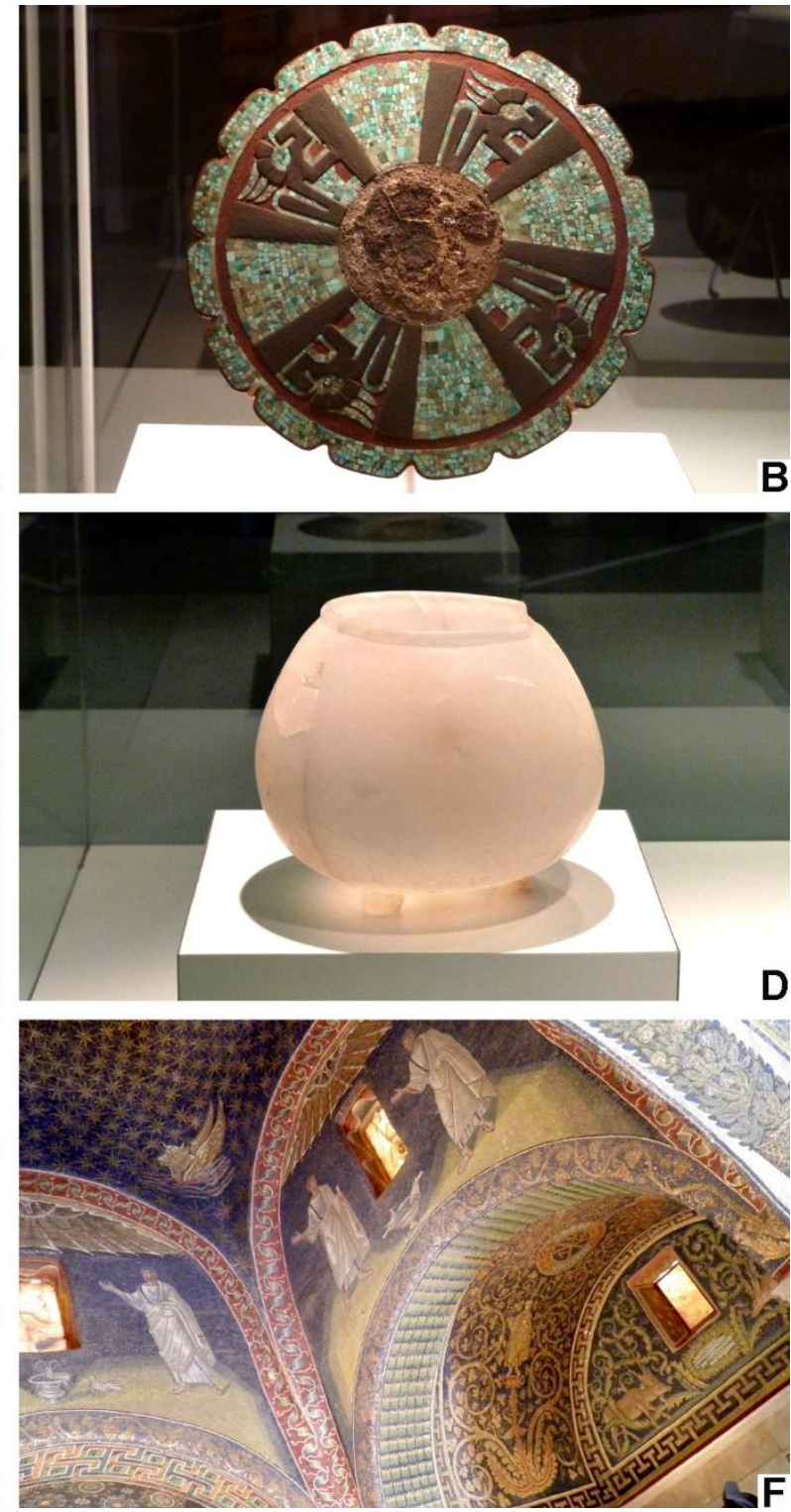

Figura 2.27. Uso de minerais em mobília e ornamentação. A. Máscara funerária feita de jadeíta e conchas. B. Disco de madeira ornamentado com turquesa, concha, coral e ardósia. C. Aparador de malaquita, Opificio delle Pietre Dure, Florença, Itália. D. Vasilha tripé de alabastro. A, B e D. Fotografias da exposição Mayas-Revelação de um tempo sem fim na Oca, São Paulo, 10/06 a 24/08/2014, gentilmente autorizadas pela organização. E. Placa de alabastro, Igreja Santa Maria in Aracoeli, Roma, Itália. F. Alabastro nas janelas do Mausoleu de Galla Placídia em Ravena, Itália, a cidade dos mosaicos. Fotografia F: Antònia G. Tinture. 


\subsubsection{Exemplos no Brasil}

No Brasil, há também diversidade dos tipos litológicos utilizados nas construções, com exemplos dos três grandes grupos de pedra.

Costa (2009) dá um panorama das pedras utilizadas no patrimônio brasileiro, com destaque para as construções mineiras, sendo a publicação mais completa deste gênero. Del Lama et al. $(2009,2015)$ descrevem as rochas utilizadas no patrimônio paulistano e Liccardo (2010) discorre sobre esse uso no Paraná.

Na cidade de São Paulo, grande parte dos seus monumentos foi construída com granitos paulistanos e paulistas, destacando-se o Granito Itaquera. Em interiores, é observada a utilização de minerais na ornamentação, como a malaquita e o alabastro, por exemplo, como na Sé e no Cemitério da Consolação, respectivamente (Figuras 2.28A a C). O Aeroporto de Congonhas possui piso constituído por mármore e basalto, propiciando desgaste diferenciado e ressaltos no piso, com maior deterioração do mármore (Figura 2.28D).

Os gnaisses predominam no Rio de Janeiro, principalmente o Gnaisse Facoidal (Figura 2.28E), também conhecido como Pedra de Gálio ou Pedra Carioca, que apesar de sua textura porfiroblástica foi muito bem trabalhado no período colonial. Também foram utilizados o leptinito e o kinzigito (Marques et al. 2010). O Cristo Redentor é constituído de concreto, mas é revestido com tesselas de esteatito, mais conhecido como pedra-sabão (Figura 2.28F).

Em Minas Gerais, foram usados quartzitos e xistos variados, canga e pedra-sabão. O quartzito é muito presente na cidade de Ouro Preto, sendo encontrado na Igreja São Francisco de Assis (Figura 2.29A), no Museu da Inconfidência (Figura 2.29B), no piso do Museu de Ciência e Técnica da Escola de Minas da UFOP, entre outros.

O emprego do calcário foi mais frequente nos estados da Bahia, Sergipe e Paraíba. Apesar do uso mais frequente do calcário em Salvador, merece destaque o frontispício da Igreja da Ordem Terceira de São Francisco (Figura 2.29C), construído em arenito e também calcário.

$\mathrm{O}$ arenito de praia, mais conhecido como beachrock, foi muito utilizado em Olinda e Recife, constituindo elementos estruturais e detalhes arquitetônicos da maior parte dos edifícios eclesiásticos (Figura 2.29D). Também foi utilizado no Forte das Cinco Pontas em Recife.

O arenito também foi a tela das pinturas rupestres da Serra da Capivara no Piauí (Figura 2.29E).

Nos Redutos das Missões foram usados um arenito (Figura 2.29F), de cor vermelha, e blocos de crosta laterítica.

Arenito ferruginizado e crosta laterítica foram muito usados na região amazônica, como na Fortaleza São José de Macapá, no Amapá.

Além das pedras brasileiras, também houve a utilização de pedras importadas principalmente de Portugal e da Itália, notadamente mármores e calcários.

Considerando a diversidade existente de pedras, nacionais e importadas, no patrimônio brasileiro, podemos dizer que o país é um grande catálogo de rochas ornamentais. 
Os exemplos apresentados constituem-se em apenas uma pequena parte do patrimônio pétreo mundial. Ressalta-se, assim, a importância da pesquisa científica para a caracterização e diagnóstico do material pétreo para subsidiar as ações de conservação da pedra e a formação de profissionais habilitados para com ela trabalhar, contribuindo para uma existência mais duradoura do nosso patrimônio construído.
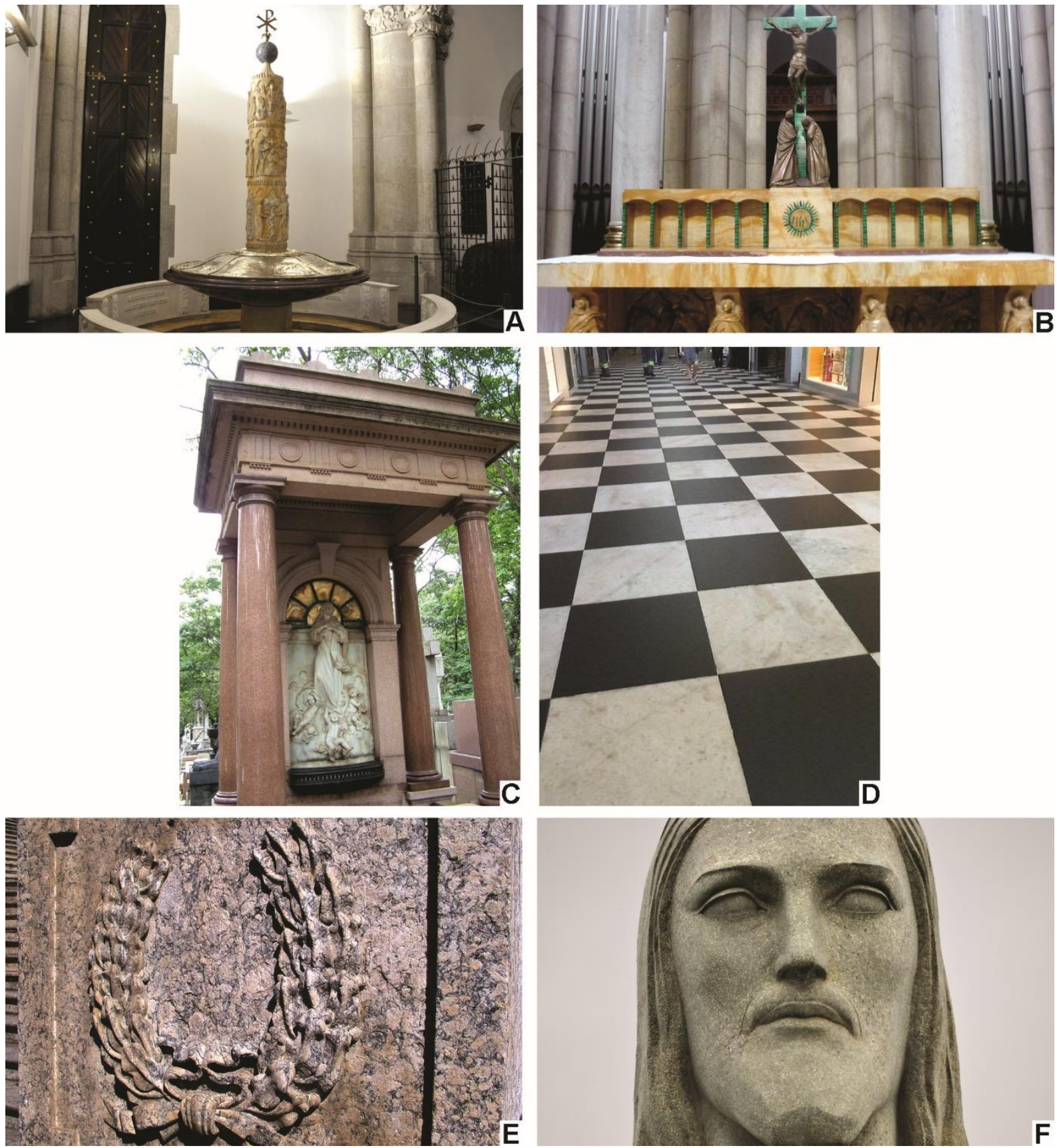

Figura 2.28. Exemplos do patrimônio pétreo brasileiro. A. Lápis-lazúli na pia batismal. B. Malaquita no crucifixo e colunas do altar. A e B. Sé de São Paulo. C. Alabastro no vitral do túmulo de Ramos de Azevedo, Cemitério da Consolação, São Paulo. D. Piso de mármore e basalto no Aeroporto de Congonhas, São Paulo. E. Gnaisse Facoidal, Sede da CPRM, Rio de Janeiro. F. Tesselas de pedra-sabão revestindo o Cristo Redentor, Rio de Janeiro. Fotografia F: Lauro K. Dehira 

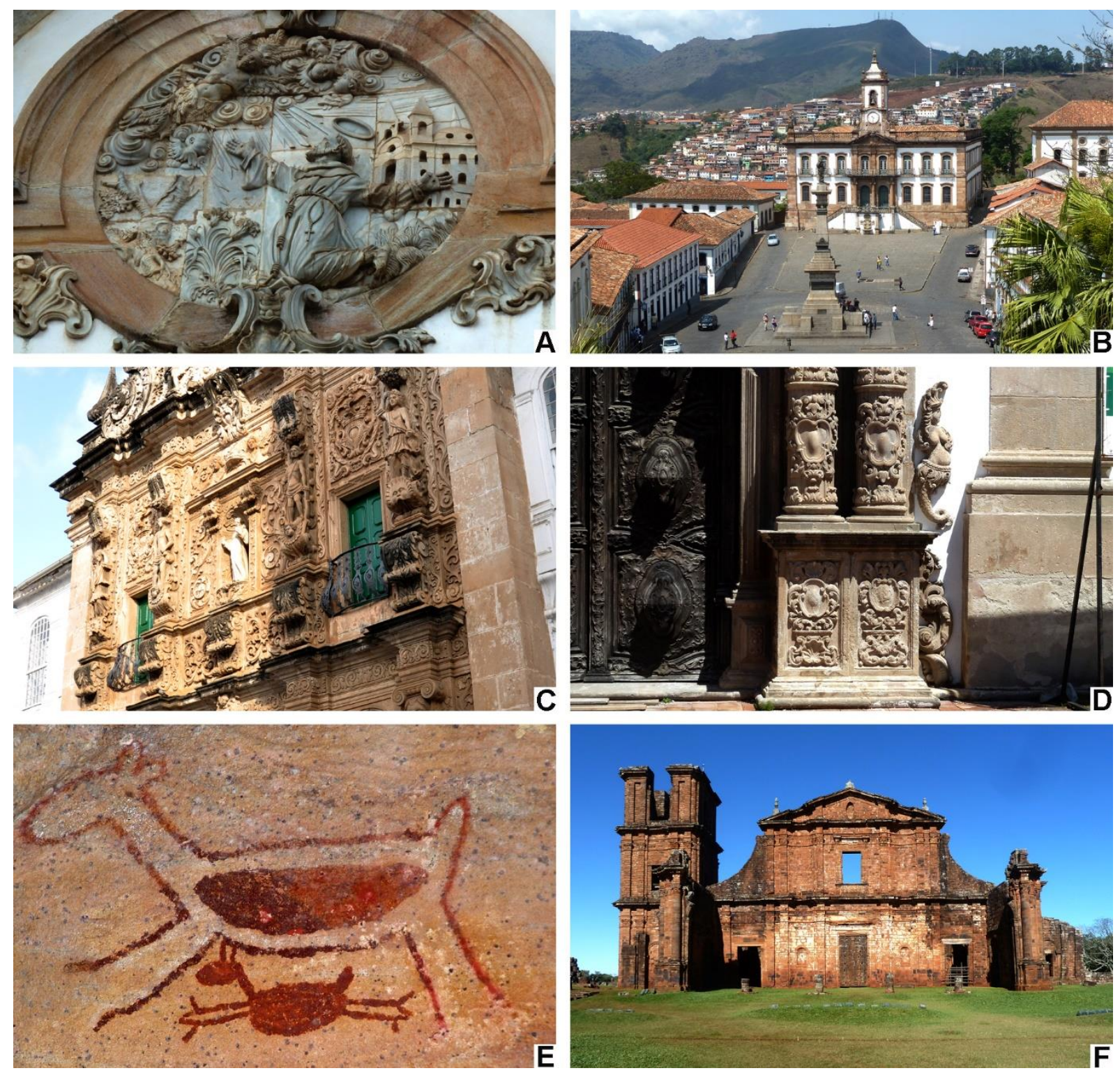

Figura 2.29. Exemplos do patrimônio pétreo brasileiro. A.Quartzito e pedra-sabão na Igreja São Francisco de Assis, Ouro Preto. B. Praça Tiradentes, Ouro Preto. Quartzito no Museu da Inconfidência ao fundo e Gnaisse Facoidal no Monumento a Tiradentes no centro (a pedra carioca foi aqui usada para lembrar que Tiradentes foi morto no Rio de Janeiro). C. Arenito na Igreja da Ordem Terceira de São Francisco, Salvador. D. Beachrock na Igreja São Pedro dos Clérigos, Recife. E. Arenito como suporte das pinturas rupestres da Serra da Capivara, Piauí. F. Arenito nas ruínas jesuíticas São Miguel das Missões, Rio Grande do Sul. Fotografias C e D: Lauro K. Dehira

\section{REFERÊNCIAS}

Adam J.P. 2005. La Construction Romaine. Paris, Picard, 368 p.

Aires-Barros L. 2001. As rochas dos monumentos portugueses - tipologias e patologias. Lisboa, IPPAR (Instituto Português do Património Arquitectónico), 535 p. 2 volumes.

Borghini G. 1989. Marmi Antichi. Roma, De Luca Edizione d'Arte, 342 p. 
Burman P. \& Drury M. 2006. The historical context. In: Henry A. (ed.) Stone Conservation. Shaftesbury, Donhead, p. 9-32.

Calvo J.P. \& Regueiro M. 2010. Carbonate rocks in the Mediterranean region - from classical to innovative uses of building stone. In: Smith B.J., Gomez-Heras M., Viles H.A., Cassar J. (eds.) Limestone in the built environment: present-day challenges for the preservation of the past. London, Geological Society, Special Publication 331, pp. 27-35.

Cooke L. 2010. The $19^{\text {th }}$ century Corsi collection of decorative stones: a resource for the $21^{\text {st }}$ century? In: Přikryl R. \& Török A. (eds.) Natural Stone Resources for Historical Monuments. London, Geological Society, Special Publication 333, pp. 185-195.

Costa A.G. 2009. Rochas e histórias do patrimônio cultural do Brasil e de Minas. Rio de Janeiro, Bem-Te-Vi, $292 \mathrm{p}$.

Dehejia V. \& Rockwell P. 2011. A flexible concept of finish: rock-cut shrines in premodern India. Archives of Asian Art, 61:61-89.

Del Lama E.A., Dehira L.K., Reys A.C. 2009. Visão geológica dos monumentos da cidade de São Paulo. Revista Brasileira de Geociências, 39(3):409-420. Disponível em: http://www.sbgeo.org.br/pub_sbg/rbg/vol39_down/3903/11163.pdf.

Del Lama E.A., Bacci D.D.L.C., Martins L., Garcia M.G.M., Dehira L.K. 2015. Urban geotourism and the old centre of São Paulo, Brazil. Geoheritage, 7(2):147-164. DOI 10.1007/S12371-0140119-7.

Dessales H. 2006. Petit Catalogue des Techniques de la Construction Romaine. Materiel Didactique-Archeologie de la Construction Romaine. Paris, Ecole Normale Supérieure, 21 p.

Dimes F.G. 1990a. Igneous rocks. In: Ashurst J. \& Dimes F.G. (eds.) Conservation of building \& decorative stone. Grã-Bretanha, Butterworth Heinemann. Part 1: p. 37-60.

Dimes F.G. 1990b. Sedimentary rocks. In: Ashurst J. \& Dimes F.G. (eds.) Conservation of building \& decorative stone. Grã-Bretanha, Butterworth Heinemann, Part 1, p. 61-134.

Dimes F.G. 1990c. Metamorphic rocks. In: Ashurst J. \& Dimes F.G. (eds.) Conservation of building \& decorative stone. Grã-Bretanha, Butterworth Heinemann, Part 1, p. 135-149.

Giampaolo C., Lombardi G., Mariottini M. 2008. Pietre e costruito della cittá di Roma: dall'antichitá ai giorni nostri. In: Funiciello R., Praturlon A., Giordano G. (eds.) La Geologia di Roma - dal centro storico alla periferia. Florença, Mem. Descr. Carta Geol. D'It., 80, pp. 273406.

Heiken G., Funiciello R., De Rita D. 2005. The seven hills of Rome - a geological tour of the eternal city. Princeton, Princeton University Press, $245 \mathrm{p}$.

Hummel R.E. 1999. Understanding Materials Science. Nova York, Springer-Verlag, 407 p.

IPPAR - Instituto Português do Património Arquitectónico. 2006. Mosteiro dos Jerónimos - a intervenção de conservação do claustro. Lisboa, IPPAR/Ministério da Cultura, World Monuments Fund. 303 p. 
Klemm D.D. \& Klemm R. 2001. The building stones of ancient Egypt - a gift of its geology. African Earth Sciences, 33:631-642.

Lazzarini L. \& Sangati C. 2004. I più importanti marmi e pietre colorati usati dagli antichi. In: Lazzarini L. (ed.) Pietre e marmi antichi. Padova, Cedam, pp. 73-100.

Liccardo A. 2010. La Pietra e l'Uomo. Cantaria e Entalhe em Curitiba. Curitiba, Beca, 156 p.

Maciel M.J. 2007. Tratado de Arquitetura - Vitrúvio. São Paulo, Martins Fontes, 556 p.

Marques E.A.G., Barroso E.V., Menezes Filho A.P., Vargas Jr. E.do A. 2010. Weathering zones on metamorphic rocks from Rio de Janeiro - physical, mineralogical and geomechanical characterization. Engineering Geology, 111:1-18.

Pereira C.A., Liccardo A., Silva F.G. 2007. A Arte da Cantaria. Belo Horizonte, Editora C/ Arte, $120 \mathrm{p}$.

Price M.T. 2007. Decorative Stone - The complete sourcebook. Londres, Thames \& Hudson, $288 \mathrm{p}$.

Přikryl R. \& Török A. 2010. Natural stones for monuments: their availability for restoration and evaluation. In: Přikryl R. \& Török A. (eds.) Natural Stone Resources for Historical Monuments. London, Geological Society, Special Publication 333, p. 1-9.

Rockwell P. 1993. The art of stoneworking - A reference guide. Cambridge and New York, Cambridge University Press, $319 \mathrm{p}$.

Schaffer R.J. 1932. The weathering of natural building stones. Reimpressão em 2004 por Donhead Publishing Ltd. 149 p.

Torem A.C.P. 2012. Projeto de restauração e conservação de pintura mural decorativa: faux marble - Investigação, resultados, procedimentos. Plano de conservação preventiva do Museu-Casa de Rui Barbosa. 46 p. Disponível em: http://www.casaruibarbosa.gov.br/dados/DOC/edicoes_online/relatorios/FCRB_Projeto_Restauraca o_Faux_Marbre.pdf.

Wheeler G. 2012. A look at the Central Park Obelisk. Nova York, $12^{\text {th }}$ Stone Conference, Guia de saída de campo. 


\section{Contexto Histórico e Textos Doutrinários}

A discussão da conservação do patrimônio histórico é bastante antiga, mas somente nos últimos dois séculos foi-se delineando algo mais concreto.

Os procedimentos foram diferentes no decorrer do tempo e nos diferentes países. E mesmo num determinado país e numa determinada época as ações se diferiram.

Sendo a Conservação um tópico multidisciplinar, é importante que os profissionais de outras ciências que pretendem atuar nessa área conheçam os principais teóricos e debatedores e sua contextualização na história.

Dessa forma, apresenta-se aqui um recorte por alguém que não possui formação na área de humanidades mas que procurou se inteirar da literatura especializada. E em sendo um recorte, levar em consideração a possibilidade da existência de lacunas.

Incentiva-se fortemente que os interessados leiam as fontes aqui citadas além de tantas outras. É a melhor maneira de evoluir no conhecimento e expandir as relações entre os cientistas (teoria) e os conservadores (prática).

Burman \& Drury (2006) citam que, Vitruvius, em sua obra De architecture (Século I a.C.), já apontava a importância da teoria e da prática, e quem tivesse domínio de ambas saberia trabalhar melhor com o objeto. Estes autores tratam do contexto histórico da conservação da pedra desde a Antiguidade, com destaque para o Movimento Arts and Crafts e reavaliam a função dos grandes arquitetos britânicos do Século XIX.

Um compêndio sobre a história da conservação arquitetônica é encontrado em Jokilehto (1999). Alguns pontos são discutidos a seguir.

No Renascimento (Século XVI), a restauração tornou-se parte da atividade normal de um escultor.

Giorgio Vasari (1511-74) em sua obra Le vite de' più eccelenti pittori, scultori e architettori (1550) escreveu: Antiguidades restauradas são mais graciosas que torsos mutilados, membros sem cabeças, ou figuras com defeito. 
Entretanto, também havia a linha da simples preservação, como é o caso do Torso de Belvedere (Figura 3.1A), considerado por muitos o trabalho mais perfeito deste tipo, que permanece sem restauração. Por outro lado, a figura de Laocoön, onde faltava o braço do pai, foi completado por hipótese. Posteriormente, foi encontrada a peça original e era bem diferente do que se supunha (Figura 3.1B).

Um dos mais influentes escritores do Renascimento, Leon Battista Alberti (1404-72) já dizia que a razão fundamental para a deterioração é a negligência humana e o descuido.

Rafaello Santi (1483-1520) é considerado o pai da proteção estatal moderna dos monumentos. Em carta endereçada ao Papa Leão $X$, ele descreve a destruição dos monumentos clássicos, o que eles representam, e seus valores como testemunhos do passado glorioso da Itália. Uma das consequências do envio da carta foi sua nomeação como Prefeito dos Mármores e Pedras de Roma.
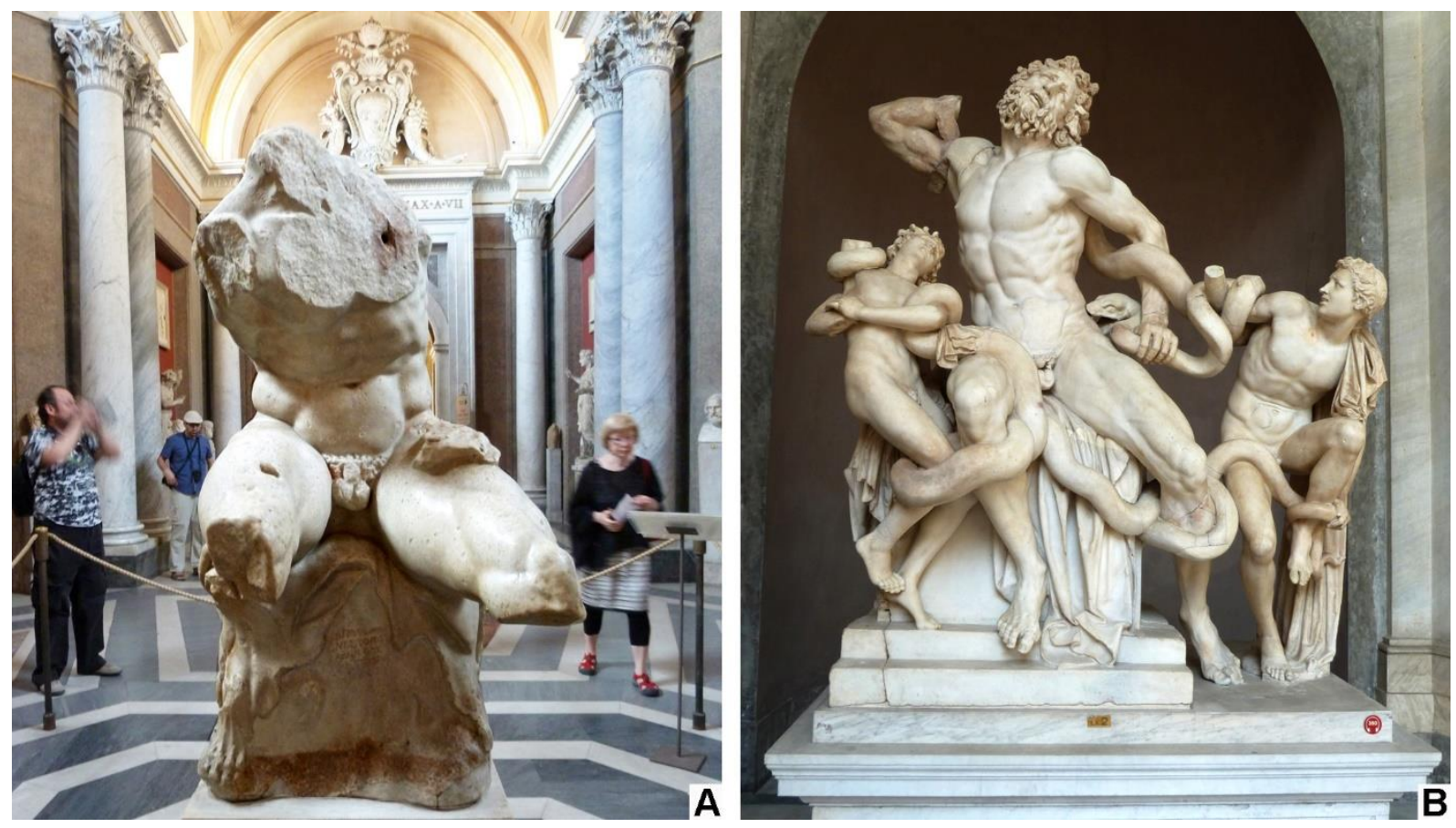

Figura 3.1. Acervo do Museu do Vaticano. A. Torso de Belvedere. B. Laocoön.

Durante o renascimento italiano foram reconhecidas as ruínas da antiga Roma como um patrimônio importante e antecipou movimentos modernos de conservação.

A Idade da Razão, ou Idade da Luz, introduziu paradigmas culturais e conceitos que fundaram o movimento da conservação moderna.

A importância da diversidade cultural e da identidade nacional foi crescendo no Século XVIII, assim como o conceito do valor universal dos monumentos históricos e das obras de arte, marcando o início da responsabilidade por sua conservação.

Johann Joachim Winckelmann (1717-68), conhecido como Pai da Arqueologia, usou o método científico para estudar, definir e avaliar artística e historicamente os objetos antigos (Figura 3.2). Contribuiu para o desenvolvimento dos princípios da conservação moderna com a distinção entre a obra original e as adições. 


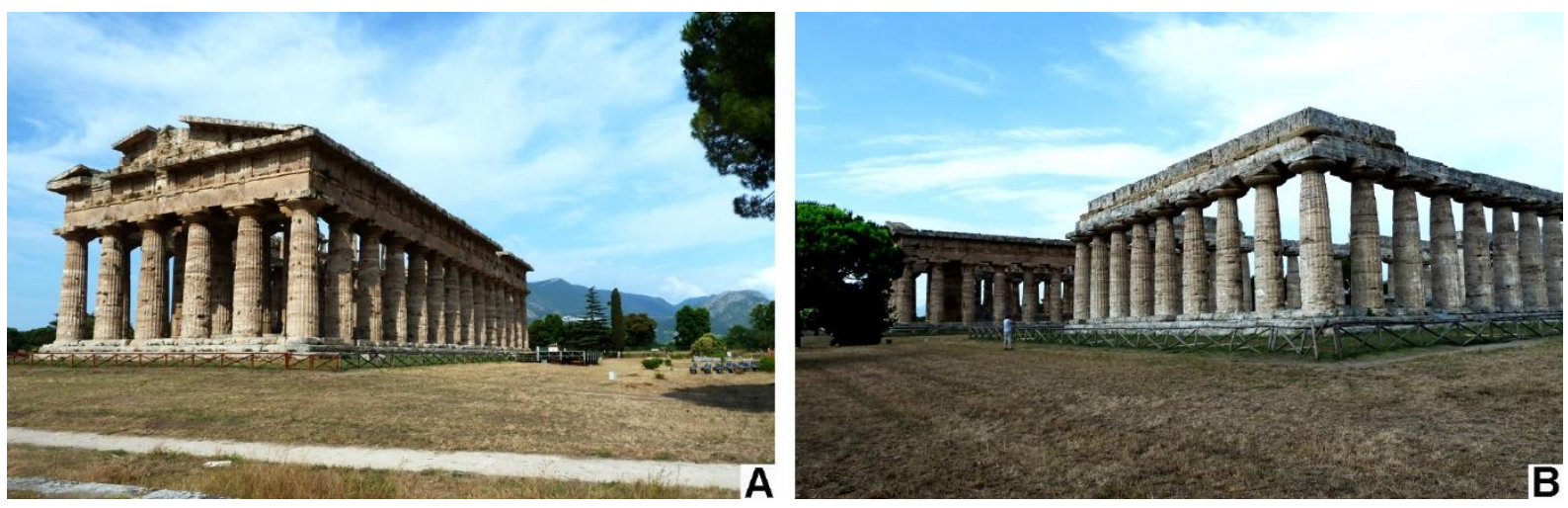

Figura 3.2. Winckelmann foi o primeiro a descrever os templos de Paestum (sul da Itália), publicado em 1762. A. Templo de Netuno. B. Templo de Hera. Século V a.C.

Na França, durante a Revolução Francesa (1789), muitos monumentos foram destruídos. Não é por acaso que a definição de monumento histórico surge na obra Antiquités Nationales em 1790, de Aubin-Louis Millin (1759-1818).

O termo vandalismo foi utilizado por Abbé Henri Grégoire (1759-1831), bispo de Blois e membro do Comité d'instruction publique. Seus relatórios de 1794 falam das destruições devido ao vandalismo e os meios para detê-lo: Bárbaros e escravos detestam conhecimento e destroem as obras de arte, homens livres amam-nas e as conservam.

Com a destruição dos edifícios franceses, as obras de arte que se salvavam eram colocadas em museus. Antoine-Chrysostome Quatremère de Quincy (1755-1849) repudiava museus, pois considerava que as obras deveriam permanecer nos seus locais de origem. Foi terminantemente contra quando Napoleão obrigou o papa Pio VI a enviar para a França obras de arte italianas famosas, conhecido como bouquet de Napoléon (livros e manuscritos raros e uma centena de obras, tais como Apolo de Belvedere, Laocoön, Torso de Belvedere e pinturas de Rafael, Correggio e Guido Reni), mas aceitou a remoção do mármore de Elgin para o British Museum, para garantir sua proteção. Vale lembrar que na época, a Grécia era domínio do Império Otomano.

A grande contribuição da Revolução Francesa para o patrimônio foi que, com a destruição e o vandalismo dos monumentos históricos, houve um novo entendimento dos valores artísticos, científicos e documentais deste patrimônio. E se, até então, estas obras de arte eram desconhecidas para o grande público, agora eram sua propriedade e estavam a seu cuidado.

Em Roma, ocorrem as restaurações do Coliseu e do Arco de Tito no começo do Século XIX (Figuras 3.3A a C), consideradas por muitos como exemplares.

Com a independência da Grécia em 1821, muitos templos clássicos foram restaurados e deu especial significado à palavra grega para restauração, a anastilose (recolocação de elementos originais encontrados), sendo o Templo de Atena Nike um caso exemplar. Outros exemplos de anastilose são a Biblioteca de Celsus em Éfesos (Turquia) e a reconstrução do templo de Pérgamo na llha dos Museus em Berlim (Alemanha) (Figuras 3.3D a F).

A partir de 1830, o movimento moderno de restauração foi impulsionado pelas políticas eclesiásticas na Inglaterra e pelas diretrizes governamentais na França. 

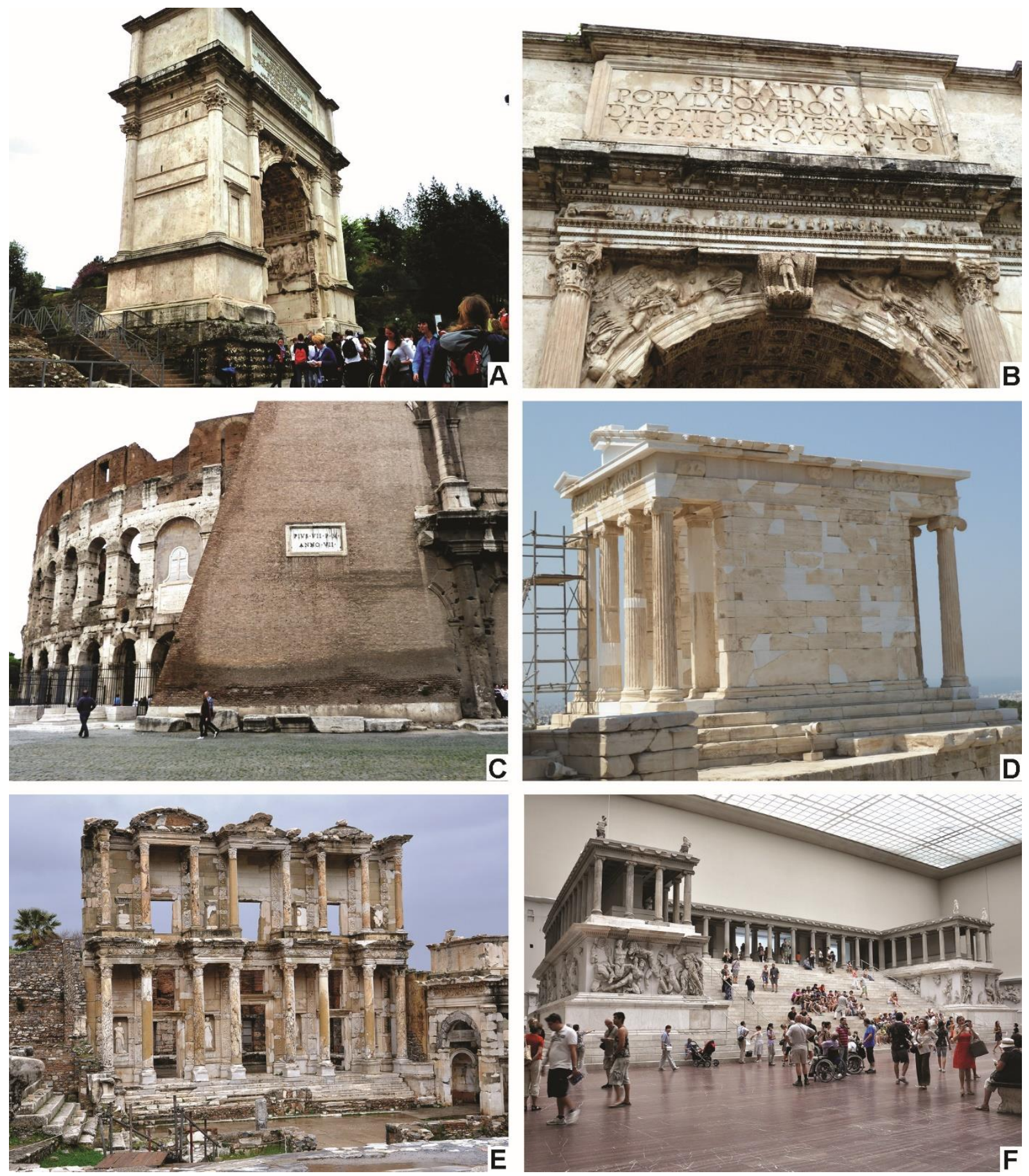

Figura 3.3. Exemplos de restauração (A a C) e anastilose (D a F). A. Arco de Tito, Roma. B. Detalhe do Arco de Tito. A parte central é original e é de mármore. As laterais foram colocadas na restauração e são de travertino. C. Coliseu, Roma. D. Templo de Atena Nike no Parthenon, Atenas. E. Biblioteca de Celsus, Éfeso. F. Templo de Pérgamo, Ilha dos Museus, Berlim.

Nos anos de 1840, Adolphe Napoléon Didron (1806-67) foi um dos mais ferrenhos críticos da restauração na França, com seu enunciado: Com relação aos monumentos antigos, é melhor consolidar que reparar, reparar que restaurar, restaurar que refazer, refazer que embelezar; e nada deve ser acrescentado, e sobretudo nada deveria ser removido.

Eugène Emmanuel Viollet-le-Duc (1814-1879) é sem dúvida uma das figuras mais controvertidas da restauração (Figura 3.4). O julgamento de seus trabalhos deve ser feito no contexto em que foram realizados e não com os olhos de hoje. Sua experiência em restauro 
começa em 1840 quando foi indicado para restaurar a Igreja de Vézelay (Kühl 2000). Suas obras mais conhecidas são Dictionnaire Raisonné de l'Architecture Française du $X I^{e}$ au XVI Siècle, publicado entre 1854 e 1868 em 10 volumes, e Entretiens sur l'Architecture, publicados entre 1863 e 1872. Possivelmente a célebre frase que inicia o verbete Restauração publicado no Dictionnaire é demasiada forte para o contexto atual:

Restaurar um edifício não é mantê-lo, repará-lo ou refazê-lo, é restabelecê-lo em um estado completo que pode não ter existido nunca em um dado momento.

No entanto, Viollet-le-Duc, em seus escritos, demonstra respeito pelas várias fases de um edifício e que a melhor maneira de conservá-lo é dar-lhe uma destinação. Ressaltou que antes de iniciar uma restauração era necessário conhecer e documentar o objeto, com relatórios e levantamentos gráficos. Compara o trabalho da restauração com a habilidade de um cirurgião, que só deve operar o paciente quando tiver conhecimento pleno do problema e de suas consequências: Mais vale deixar morrer o doente do que o matar.

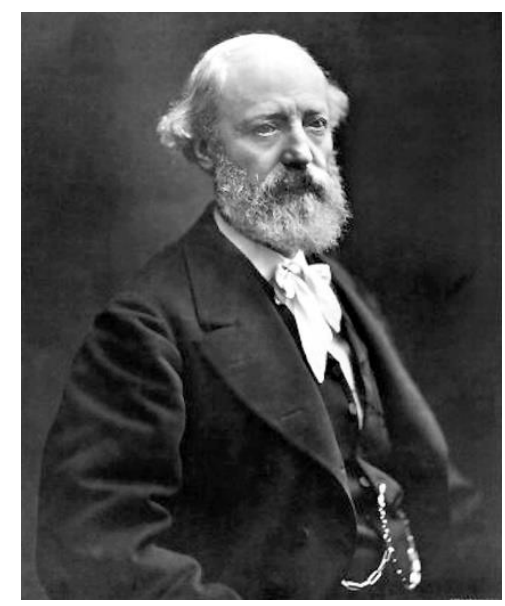

Figura 3.4. Eugène Emmanuel Viollet-le-Duc. Fonte: http://en.wikipedia.org/wiki/Eug\%C3\%A8ne_Viollet-le-Duc.

O Dictionnaire Raisonné de l'Architecture Française influenciou grandes nomes como Victor Horta e Antônio Gaudi que se inspiraram nos desenhos de Viollet-le-Duc (Andrade 1993). Mesmo John Ruskin, sempre contrário às ideias de Viollet-le-Duc, declarou que gostaria de ter escrito esta obra.

Além dos estudos de arte e arquitetura, Viollet-le-Duc também tinha interesse nas montanhas e em geologia (Jokilehto 1999).

Oliveira \& Santiago (2014) discutem o restauro da igreja de Notre-Dame de Paris, realizado por Viollet-le-Duc e Jean-Baptiste Antoine Lassus (1807-1857), apontando que, parte dos procedimentos utilizados seria compatível com as doutrinas da restauração atuais, enquanto a outra parte não.

A excessividade de algumas intervenções tornou Viollet-le-Duc o símbolo da restauração destrutiva (Figura 3.5). O mesmo ocorreu com George Gilbert Scott na Inglaterra. O fato é que Viollet-le-Duc teve uma imensa influência na área de restauração, progressivamente abandonada após a reunião de Atenas em 1931. 

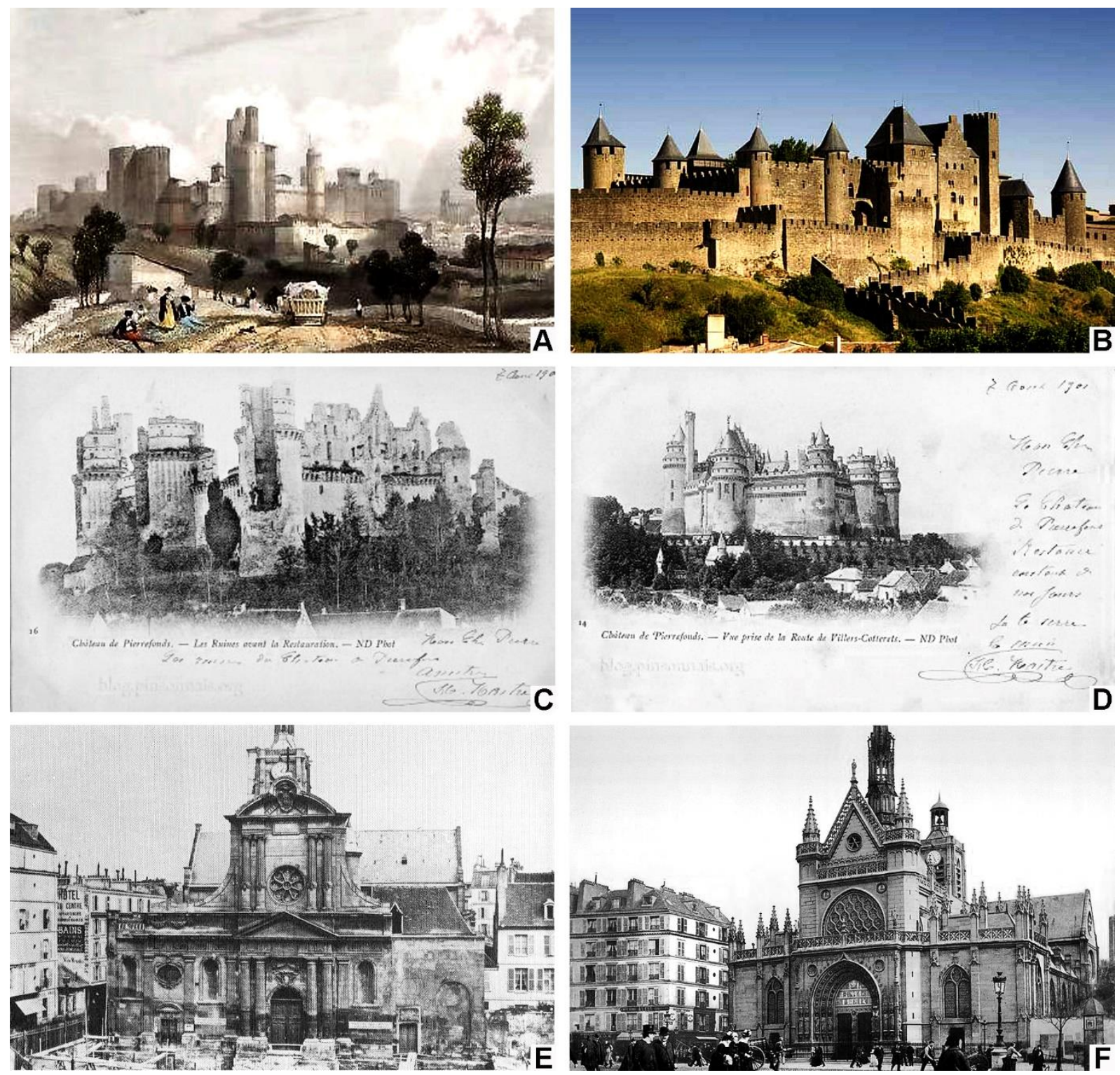

Figura 3.5. Edifícios restaurados por Viollet-le-Duc. Castelo de Carcassone: A. Antes da restauração (Fonte:

http://www.antique-prints.de); B. Depois da restauração. (Fonte: http://www.google.com.br). Castelo de Pierrefonds: C. Foto tirada em 1860; D. Depois da restauração, ca. 1890-1900 (Fonte: http://blog.pinsonnais.org/post/2009/04/06/Une-restauration-deViollet-le-Duc). Igreja Saint-Laurent de Paris: E. Foto de 1861; F. Depois da restauração (Fonte:

http://fr.wikipedia.org/wiki/\%C3\%89glise_Saint-Laurent_(Paris).

John Ruskin (1819-1900), Figura 3.6, foi o principal teórico na área da preservação do Século XIX na Inglaterra com o Movimento Anti-Restauração e o grande opositor de Viollet-le-Duc. Suas publicações tratavam de vários assuntos: arte, arquitetura, história, temas sociais e políticos e também geologia. Tinha uma admiração especial por montanhas, cristais e minerais (Jokilehto 1999).

The Seven Lamps of Architecture (Sacrifício, Verdade, Poder, Beleza, Vida, Memória e Obediência), publicada em 1849, é uma das principais obras de Ruskin. O Capítulo VI trata da preservação: A Lâmpada da Memória. Ruskin (1949) aponta aí que a maior glória de um edifício é evidenciar sua idade, sendo que a restauração é a total destruição de um edifício. Se cuidar bem de um edifício, não será necessário restaurá-lo. 
Ruskin relaciona o estilo arquitetônico com o tipo de material utilizado. Por exemplo, com o gótico francês deveria ser utilizado tijolo, arenito ou calcário; com o gótico italiano deveria ser utilizado granito, serpentina e mármore. Provavelmente o termo serpentina por ele referido corresponda a um tufo vulcânico de cor verde ou a um serpentinito.

O Museu de História Natural de Oxford é a única obra com elementos arquitetônicos desenhados por Ruskin (Pinheiro 2008).

Inspirado nas obras The Seven Lamps of Architecture e The Stones of Venice (1851-1853) de John Ruskin, desenvolve-se o Movimento Arts and Crafts, que defende o artesanato criativo e revalorização do trabalho manual, tendo como principal líder William Morris (1834-1896) (Figura 3.7).

A partir das ideias de Ruskin, William Morris fundou a Society for the Protection of Ancient Buildings - SPAB (Sociedade para a Proteção dos Edifícios Antigos) em 1877, em Londres.

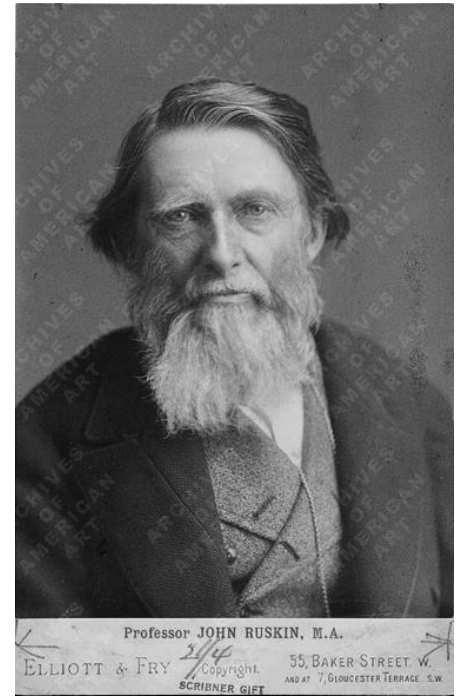

Figura 3.6. John Ruskin, $c a$. 1879. Fonte:

http://www.aaa.si.edu/collections/viewer/john-ruskin-7896.

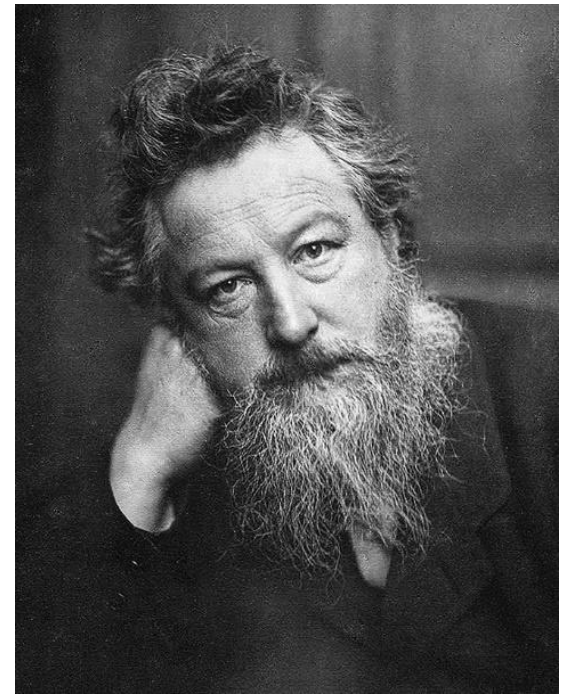

Figura 3.7. William Morris. Fonte: http://en.wikipedia.org/wiki/William_Morris.

A conservação moderna foi precedida por um processo de conscientização pelo esforço de humanistas e artistas, e que foi acompanhado pela montagem de coleções de artefatos históricos e obras de arte, pelo turismo cultural e pelo estabelecimento de museus.

No fim do Século XIX firma-se o restauro filológico, também conhecido como restauro científico, que tem uma abordagem histórica. Esta abordagem pode ser derivada da definição latina de monumento: inscrição ou documento. Nesta linha dava-se ênfase ao aspecto documental da obra e o respeito das várias fases de sua história.

Camilo Boito (1836-1914), Figura 3.8, foi o responsável pela consolidação do restauro filológico na Itália no final do século XIX. Como princípio geral pregou a mínima intervenção. Boito (1893) propôs recomendações para a intervenção em monumentos históricos, sendo elas a importância do valor documental do monumento; se fossem necessários acréscimos e renovações que fossem efetuados com caráter diverso do original e se adequar ao todo; 
partes deterioradas ou faltantes poderiam ser completadas, mas com material diverso ou registrada a data da restauração, e com formas simplificadas no caso das restaurações arqueológicas; consolidação apenas para se evitar a perda de elementos característicos; as várias fases do monumento deveriam ser respeitadas, permitindo remoção apenas se tiver qualidade artística muito inferior; documentar as obras com fotografias, descrições e justificativas; e colocar uma lápide nas obras com a data do restauro realizado.

Boito dividiu a arquitetura em três classes de acordo com a idade: antiga, medieval e, a partir do Renascimento, como moderna, distinguidas por valores arqueológico, aparência pitoresca e beleza arquitetônica, respectivamente.

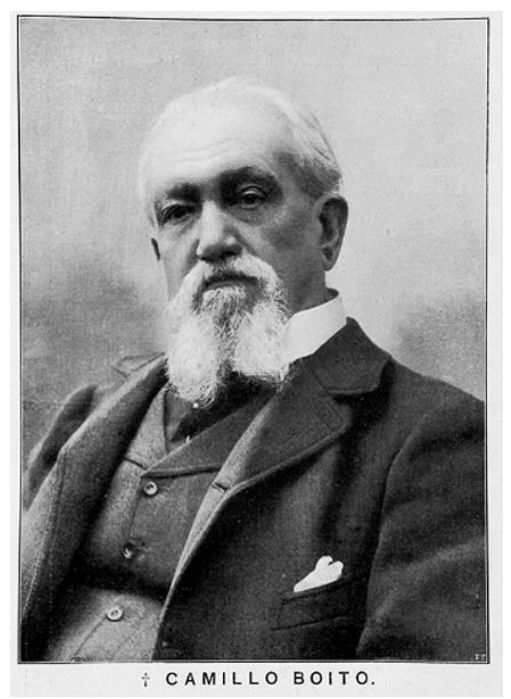

Figura 3.8. Camilo Boito. Fonte: http://www.150storiaditalia.it/?param=cultura-e-scienza/letteratura-e-cultura-italiana-18611945/dalla-scapigliatura-al-futurismo-anticonformismo-e-avanguardia/\#colSx.

Alois Riegl (1857-1905), Figura 3.9, em seu texto sobre o culto moderno dos monumentos, classifica monumentos como intencionais e não-intencionais: aqueles seriam memoriais, um produto humano para uma proposta específica, enquanto estes seriam monumentos de arte e história, que adquiriram este status posteriormente a sua concepção. Também falou sobre os valores: de idade, histórico, comemorativo e de uso. Foi o primeiro autor a dizer que os valores atribuídos ao patrimônio mudam com o tempo.

Max Dvořák (1874-1921), Figura 3.10, é representante da Escola de Viena de História da Arte e foi discípulo de Alois Riegl, e refere-se à preservação de monumentos e aos perigos que ameaçam os monumentos antigos, quais sejam: ignorância, negligência, cobiça, fraude, ideia equivocada de progresso, embelezamento e renovação das cidades.

Aponta que a proteção dos monumentos deve ser feita para obras muito conhecidas e as nem tanto, independente do estilo, pois as pessoas admiram os monumentos antigos, mas elas não reconhecem os estilos antigos, e sim a representatividade do monumento para aquele lugar. Considera que a preservação dos monumentos é obrigação dos povos e das nações, e nada esvaziaria mais um povo que a sua destruição, e deve-se sempre exigir que a 
integridade, a identidade com o ambiente, a forma e a aparência dos monumentos sejam mantidas (Dvořák 1916). Apesar do texto ser centenário, é considerado ainda muito atual.

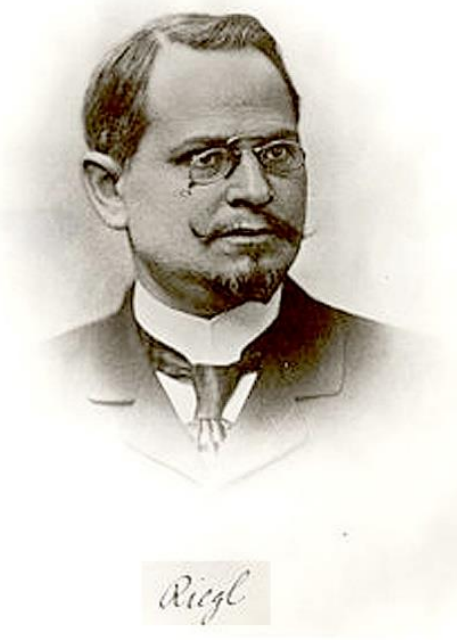

Figura 3.9. Alois Riegl. Fonte: http://en.wikipedia.org/wiki/Alois_Riegl.

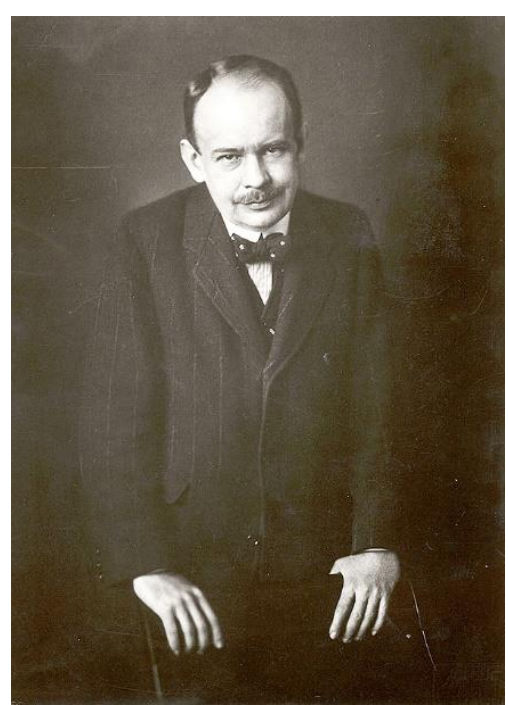

Figura 3.10. Max Dvořák. Fonte: http://pt.wikipedia.org/wiki/Max_Dvo\%C5\%99\%C3\%A1k\#medi aviewer/Ficheiro:Max_Dvorak.jpg.

O verbete Restauro de Monumentos da Enciclopedia Italiana (1936), escrito por Gustavo Giovannoni (1873-1947), Figura 3.11, já falava da dualidade Viollet-le-Duc X Ruskin e o equilíbrio posterior de Boito e do próprio Giovannoni.

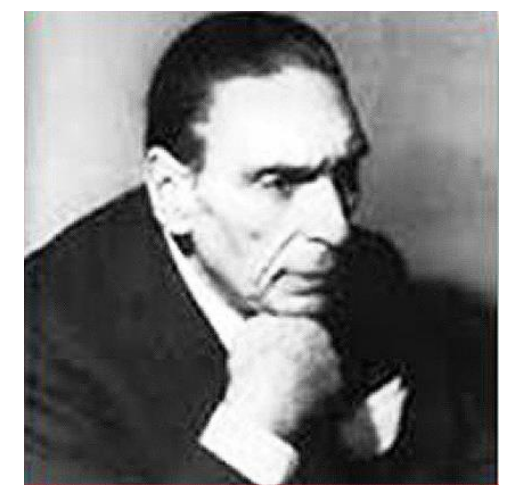

Figura 3.11. Gustavo Giovannoni. Fonte: http://tecniarte.files.wordpress.com/2011/01/custavo.jpg.

Giovannoni consolidou os princípios da conservação moderna na Itália, enfatizando a abordagem crítica e científica, estabelecendo as bases do restauro científico. Esta política foi aplicada para monumentos e edifícios históricos, além de ter iniciado a tratativa para áreas urbanas históricas. Para ele, restauração é um problema cultural de avaliação, e a reabilitação de edifícios históricos de todos os períodos significantes, ao invés da reconstrução para uma forma ideal. 
O restauro arquitetônico, que teve sua figura máxima em Viollet-le-Duc, ficou bem marcado na França com o restauro das grandes catedrais do século XIII.

A Conferência de Atenas em 1931 foi a primeira a considerar um código de prática para conservação.

Devido à devastação da Europa provocada pela 2a Guerra Mundial, entre 1940 e 1960, houve o culto do novo, e muitas empresas inglesas que poderiam reparar edifícios antigos, com habilidade e materiais tradicionais, foram cada vez menos acionadas. Ao mesmo tempo, no âmbito internacional, começou o interesse no passado e pelo turismo cultural (Burman \& Drury 2006).

Após a 2a Guerra Mundial, o restauro filológico mostrou-se limitado, pois não atendia os aspectos figurativos, surgindo assim o restauro crítico. Engloba os princípios anteriores (respeito das diversas fases e difenciação de ações posteriores) e introduz teorias estéticas e questões ligadas à percepção (Kühl 2013).

Cesare Brandi (1906-1988), Figura 3.12, escreveu a famosa Teoria da Restauração. Seu nome confunde-se com o Instituto Centrale del Restauro (ICR), fundado em 1939 em Roma, tendo sido seu diretor por duas décadas. Brandi (1963) conceitua restauro como o momento metodológico do reconhecimento da obra de arte, na sua consistência física e na sua dúplice polaridade estética e histórica, com vistas à sua transmissão para o futuro. Sustentava a especificidade de uma obra de arte, justificando que ela foi o resultado de um processo único e criativo. Aponta a importância do material como suporte da obra de arte e responsável por sua transmissão às gerações futuras. Seus axiomas são muito claros: restaura-se somente a matéria da obra de arte e restauração deve visar ao restabelecimento da unidade potencial da obra de arte, desde que isso seja possível sem cometer um falso artístico ou um falso histórico, e sem cancelar nenhum traço da passagem da obra de arte no tempo.

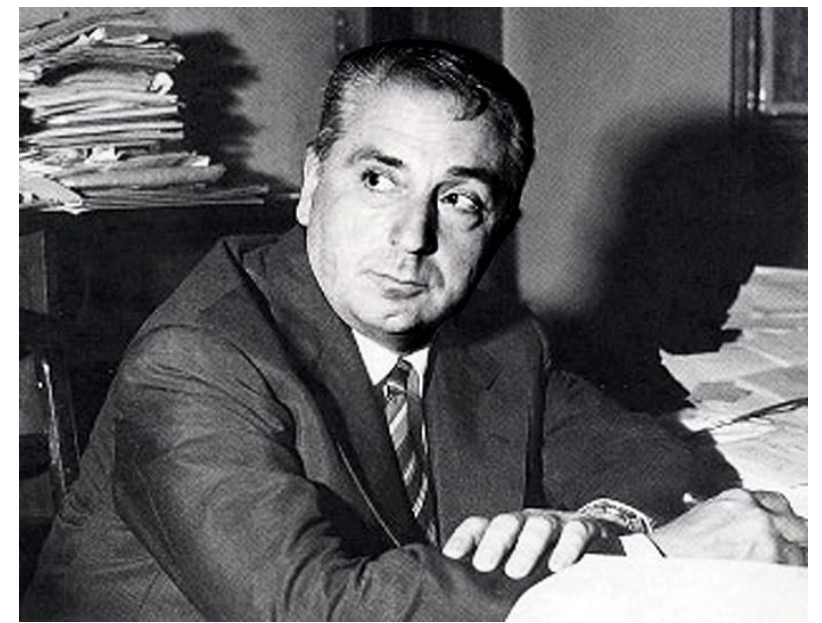

Figura 3.12. Cesare Brandi. Fonte: http://193.175.110.9/hornemann/german/epubl_detail_tagungen12_166.php.

Uma obra de arte deve ser considerada como um todo e não o total. Por exemplo, em um mosaico, o total das peças não forma o todo. Sendo assim, os limites de uma intervenção são 
definidos em relação à unidade potencial e aos registros autênticos da condição original. Resultam assim alguns princípios práticos:

- a integração deverá ser sempre e facilmente reconhecível; mas sem que por isso se venha a infringir a própria unidade que se visa a reconstituir;

- a matéria de que resulta a imagem é insubstituível só quando colaborar diretamente para a figuratividade da imagem como aspecto, e não para aquilo que é estrutura;

- qualquer intervenção de restauro não torne impossível mas, antes, facilite as eventuais intervenções futuras.

Brandi discute as lacunas, e afirma que o pior em uma obra de arte não é o que falta mas o que foi colocado de maneira inadequada.

O patrimônio natural também foi contemplado por Brandi, estendendo o conceito de restauração preventiva e de conservação às paisagens.

Com relação às ruínas, as ações devem ser conservativas e não integrativas.

Em seguida à publicação da Teoria do Restauração, em 1964 é editada a Carta de Veneza (Carta internacional sobre conservação e restauração de monumentos e sítios - 1964). A Carta de Veneza foi aprovada pelo Segundo Congresso Internacional de Arquitetos e Técnicos de Monumentos Históricos, em 1964 na cidade de Veneza, sendo uma revisão da Carta de Atenas de 1931, e foi baseada em norma italiana, a carta de Giovannoni. Outras recomendações deste congresso incluíram a criação do Conselho Internacional de Monumentos e Sítios - ICOMOS (International Council of Monuments and Sites), que posteriormente adotou a Carta de Veneza como base para estudos de restauro. Objetiva resguardar a obra de arte e a componente histórica, incluindo sua envoltória, primando pela permanente manutenção. A restauração é uma atividade excepcional e deve ser realizada, quando necessária, após exaustivo diagnóstico da obra. As mudanças necessárias devem ser facilmente distinguíveis, respeitando as várias fases da obra e o fabric original, e sempre com documentação completa de todas as etapas de trabalho.

O ICOMOS é uma associação não governamental, ligada à Unesco. Fundada em 1965, tem por objetivo coletar, avaliar e divulgar informações sobre princípios de conservação, técnicas e políticas, com base na Carta de Veneza (1964). Conta com 27 comitês científicos, incluindo o da pedra (Stone - ISCS).

A Carta possui 16 artigos e considera monumentos as obras de arte que obtiveram significado cultural ao longo do tempo, das mais grandiosas às mais modestas. No Artigo $2^{\circ}$ a Geologia pode ser contemplada: A conservação e a restauração de monumentos constituem disciplina que apela para todas as ciências e todas as técnicas, que possam contribuir para o estudo e salvaguarda do patrimônio monumental.

Kühl (2010) faz uma análise crítica da Carta de Veneza e expõe o porquê dela continuar sendo um documento base.

Dentre outros documentos internacionais importantes podem ser citadas a Carta de Restauração e a Carta de Burra. 
A Carta de Restauração - 1972 é uma normativa italiana. Anteriormente, uma outra Carta de Restauração já havia sido editada em 1931, mas não teve força de lei. A atual carta possui 12 artigos e 4 anexos.

Os primeiros artigos identificam as obras de arte, devendo as mesmas ser salvaguardadas por ações conservativas sem intervenção direta e, quando necessárias, serem restauradas. Proíbem-se os completamentos, remoções, reconstruções e descreve as operações permitidas. Estas precisam ser bem estudadas e justificadas a fim de não prejudicar eventuais futuras intervenções, sendo que todas as operações devem conter o devido registro.

No artigo $8^{\circ}$ a Geologia pode ser incluída: ... com o subsídio da física, da química, da microbiologia e de outras ciências.

Novos procedimentos e novos materiais são permitidos, desde que autorizado pelo Ministro da Instrução Pública.

A salvaguarda e a restauração de monumentos arqueológicos está instruída no Anexo A e o Anexo $B$ dá instruções para a condução das restaurações arquitetônicas. Aponta que grampos ou hastes de ferro presentes em blocos de pedras, quando necessário, devem ser substituídos por bronze, ou uma opção que não mancha a pedra: aço inoxidável. Sugere a descalcificação da água para a conservação das fontes de pedra ou de bronze, medida seguramente difícil de se conseguir, como mostram as várias fontes de Roma.

O Anexo $C$ dá instruções para a execução de restaurações pictóricas e escultóricas e o Anexo D dá instruções para a tutela dos centros históricos.

A Carta de Burra (1979-1999) é uma carta nacional, produzida pelo ICOMOS da Austrália. Introduz o conceito de localidade e o significado cultural desta localidade é melhor compreendida após uma sequência de investigações, decisões e ações. Primeiro, entendese o significado; depois, desenvolvem-se políticas; e por fim, faz-se o gerenciamento.

$\mathrm{Na}$ década de 1990 surgiu a doutrina relacionada ao desenvolvimento sustentável, exemplificada pela Declaração do Rio sobre Meio Ambiente e Desenvolvimento (1992) e pela Declaração de Istambul da Habitat II (1996).

Muñoz Viñas (2005) discute a teoria contemporânea da conservação, que é baseada em negociação, equilíbrio, discussão e consenso. O conservador faz escolhas, e elas envolvem considerações éticas, porque estas escolhas afetam não só o objeto, mas também as pessoas para quem este objeto tem algum significado. E neste processo existem os interesses político, econômico e cultural.

Intervir no patrimônio não é tarefa fácil. Todos os documentos e as teorias de restauro fornecem diretrizes para decidir, não são regras a seguir cegamente como receitas, mas devem ser entendidos na sua intenção e analisados com as particularidades do objeto em estudo. E sempre as tomadas de decisão devem ser embasadas cientificamente.

As intervenções são ações do nosso tempo, e como tal devem ser claras, registradas, respeitando as estratificações e intervindo o mínimo possível e só quando necessário, permitindo a sua identificação no futuro. 


\subsection{Instrumentos Internacionais}

A salvaguarda do patrimônio é respaldada por instrumentos internacionais. Estes são subdivididos em convenções, recomendações, declarações e cartas. Os três primeiros normalmente são adotados sob os auspícios da Unesco.

As convenções têm peso de lei internacional e são ratificadas pelos Estados membros. São elas:

- Convenção para a Proteção da Propriedade Cultural em Caso de Conflito Armado (Convenção de Haia, 1954);

- Convenção sobre os Meios de Proibir e Prevenir Importação, Exportação e Transferência llícitas de Propriedade Cultural (1970);

- Convenção sobre a Proteção do Patrimônio Cultural e Natural Mundial (Convenção do Patrimônio Mundial, 1972);

- Convenção sobre a Proteção do Patrimônio Cultural Subaquático (2001);

- Convenção para a Salvaguarda do Patrimônio Cultural Intangível (2003).

As recomendações sugerem os Estados ou os indivíduos a adotarem uma abordagem particular ou a agir de determinada maneira em uma esfera cultural específica. Seguem exemplos:

- Recomendação dos Princípios Internacionais Aplicáveis a Escavações Arqueológicas (1956);

- Recomendação à salvaguarda da beleza e da característica de locais e paisagens (1962);

- Recomendação sobre os Meios de Proibir e Prevenir Exportação, Importação e Transferência llícitas de Propriedade Cultural (1964);

- Recomendação relativa à preservação dos bens culturais ameaçados por obras públicas ou privadas (1968);

- Recomendação com relação à Proteção, no Nível Nacional, do Patrimônio Natural e Cultural (1972);

- Recomendação sobre a Salvaguarda e Papel Contemporâneo de Áreas Históricas (1976);

- Recomendação sobre a Troca Internacional de Propriedade Cultural (1976);

- Recomendação para a Proteção de Propriedade Cultural Móvel (1978);

- Recomendação sobre Paisagem Urbana Histórica, incluindo um glossário de definições (2011).

As declarações são compromissos morais ou políticos dos Estados ou indivíduos e são baseados na boa-fé, exemplificadas abaixo:

- Declaração dos Princípios da Cooperação Cultural Internacional (1966);

- Declaração Universal da Unesco sobre Diversidade Cultural (2001);

- Declaração da Unesco sobre a Destruição Intencional do Patrimônio Cultural (2003). 
As convenções, recomendações e declarações citadas acima podem ser encontradas em: http://portal.unesco.org/en/ev.php-URL_ID=12025\&URL_DO=DO_TOPIC\&URL_SECTION=-471.html.

As cartas são textos doutrinários aprovados por uma organização e fornecem orientações sobre a melhor prática no campo. Com relação ao patrimônio imóvel, o ICOMOS geralmente assume a liderança. Exemplos são citados a seguir:

- Carta Internacional para a Conservação e Restauração de Monumentos e Sítios (Carta de Veneza, 1964);

- Carta dos Jardins Históricos (Carta de Florença, 1981);

- Carta para a Conservação das Cidades Históricas e Áreas Urbanas (Carta de Washington, 1987);

- Carta para a Proteção e Gestão do Patrimônio Arqueológico (1990);

- Carta para a Proteção e Gestão do Patrimônio Cultural Subaquático (1996);

- Carta Internacional de Turismo Cultural - Gestão de Turismo em Locais de Significado Patrimonial (1999);

- Princípios para a Preservação de Estruturas Históricas de Madeira (1999);

- Carta do Patrimônio Construído Vernacular (1999);

- Princípios para a Análise, Conservação e Restauração de Estruturas do Patrimônio Arquitetônico (2003);

- Princípios para a Preservação e Conservação-Restauração de Pinturas Murais (2003);

- Carta sobre a Interpretação e Apresentação de Sítios do Patrimônio Cultural (2008);

- Carta sobre os Itinerários Culturais (2008);

- Princípios para a Conservação de Locais, Estruturas, Áreas e Paisagens do Patrimônio Industrial (2011);

- Princípios de Valletta para a Salvaguarda e Gestão de Cidades Históricas e Áreas Urbanas (2011).

Estes documentos podem ser encontrados em: http://www.icomos.org/en/charters-and-texts.

\section{REFERÊNCIAS}

Andrade A.L.D. de. 1993. Estado completo que pode jamais ter existido. Tese de Doutorado, FAU-USP, São Paulo-SP, 168 p.

Boito C. 1893. Questioni Pratiche di Belle Arti. In: Kühl B.M. Os Restauradores: Camilo Boito. Cotia, Ateliê Editorial, 63 p. (Tradução: Paulo e Beatriz M. Kühl, 2002.)

Brandi C. 1963. Teoria da Restauração. Cotia, Ateliê Editorial, 261 p. (Tradução: Beatriz M. Kühl, 2004).

Burman P. \& Drury M. 2006. The Historical Context. In: Henry A. (ed.) Stone Conservation. Shaftesbury, Donhead, p. 9-32. 
Dvořák, M. 1916. Catecismo da preservação de monumentos. São Paulo, Ateliê Editorial, 128 p. (Traduçao: V.A.E. Lima, 2008.)

Giovannoni G. 1936. Verbete: Restauro dos Monumentos. In: Kühl B.M. (org.) Gustavo Giovannoni. Textos Escolhidos. Cotia, Ateliê Editorial, 2013. 208 p.

Jokilehto J. 1999. A history of architectural conservation. Oxford, Butterworth-Heinemann, 354 p.

Kühl B.M. 2000. Restauração. Eugène Emmanuel Viollet-le-Duc. Cotia, Ateliê Editorial, 76 p.

Kühl B.M. 2010. Notas sobre a Carta de Veneza. Anais do Museu Paulista, São Paulo, 18(2):287-320.

Kühl B.M. 2013. Observações sobre os textos de Gustavo Giovannoni traduzidos nesta edição. In: Kühl B.M. (org.) Gustavo Giovannoni. Textos Escolhidos. Cotia, Ateliê Editorial, p. 11-29.

Muñoz Viñas S. 2005. Contemporary theory of conservation. Amsterdam, Elsevier, 239 p.

Oliveira M.M. \& Santiago C.C. 2014. Viollet-le-Duc e o restauro de Notre-Dame. Salvador, Editora da UFBA, $120 \mathrm{p}$.

Pinheiro M.L.B. 2008. John Ruskin e as Sete Lâmpadas da Arquitetura - Algumas Repercussões no Brasil. In: Ruskin J. 1849. A Lâmpada da Memória. (Tradução: Maria Lúcia Bressan Pinheiro.). Cotia, Ateliê Editorial, p. 9-48.

Ruskin J. 1849. A Lâmpada da Memória. Cotia, Ateliê Editorial, 2008. 88 p. (Tradução: Maria Lúcia Bressan Pinheiro.) 


\section{Deterioração da pedra}

A pedra, quando não alterada, geralmente tem grande durabilidade, isto é, não se deteriora muito rápido, mas ela não é eterna, sendo considerada um recurso natural não renovável. $\mathrm{A}$ alteração da pedra pode ser um processo natural ou não. Nos estudos de conservação, diversos autores nacionais e internacionais utilizam às vezes nomenclatura diferente para um mesmo processo ou feição de alteração, o que muitas vezes leva a confusões e falta de uniformidade de comunicação, além de existir termos ingleses sem correspondência na língua portuguesa (por exemplo, decay).

Nesta tese são usadas as denominações intemperismo e deterioração, sendo que: intemperismo é o processo natural de alteração da pedra devido a fatores intrínsecos e extrínsecos, e deterioração é a modificação da pedra segundo a ótica da conservação, tendo assim alguma influência antrópica somada aos fatores naturais.

Os fatores intrínsecos estão relacionados com os constituintes minerais, a estrutura e a quantidade de poros e/ou fraturas.

Os fatores extrínsecos incluem temperatura, precipitação, umidade relativa, exposição solar, luminosidade, vento e gelo.

O comportamento de um arenito e de um calcário não tem similaridade, pois a mineralogia os distingue com as suas dureza, solubilidade e expansão térmica diferentes. O quartzo do arenito tem dureza alta e solubilidade muito baixa; a calcita do calcário tem dureza baixa, solubilidade alta e dilatação térmica fortemente anisotrópica. A questão da solubilidade facilita o reconhecimento destas pedras nos edifícios: o arenito quando exposto escurece devido à incorporação de sujidade, e quando está protegido a coloração é mais clara enquanto que, para o calcário, o comportamento é o oposto (Figura 4.1).

O não conhecimento de certas características - como as decorrentes da interação das características petrográficas, físicas e mecânicas das pedras com os agentes do meio ambiente e os procedimentos de fixação, limpeza e manutenção, executados por nãoespecialistas - têm conduzido à deterioração ainda mais acentuada das pedras dos monumentos, ao invés de conservá-las. O resultado pode ser a alteração da superfície exposta da pedra, modificando ou danificando seu aspecto estrutural ou estético, pela perda de brilho e manchamentos (Frascá 2003). 

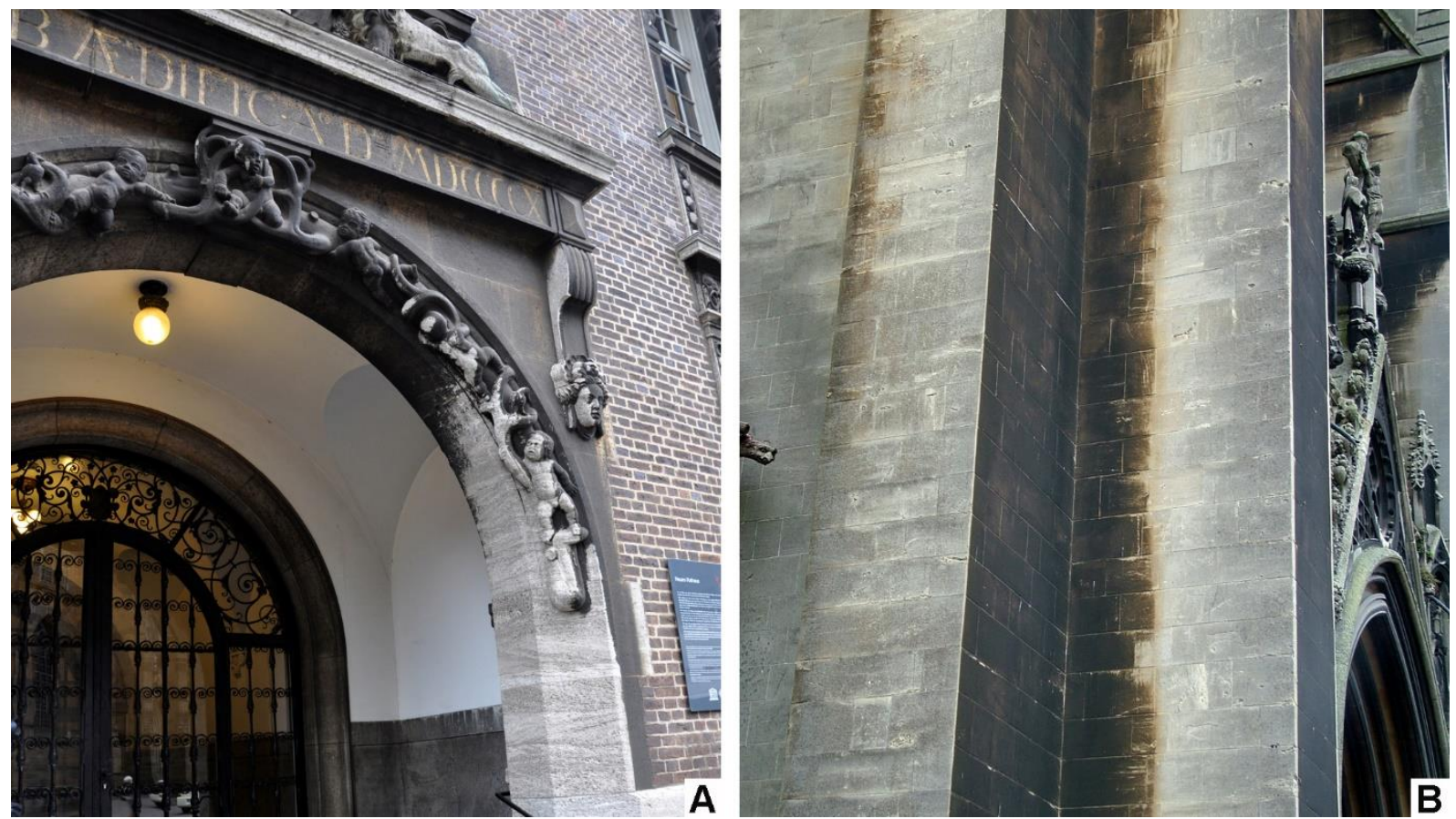

Figura 4.1. Comportamento do calcário. Em área abrigada, tende a ficar escuro, em área desabrigada tende a ser mais claro. A. Bremen, Alemanha. B. Igreja Nossa Senhora dos Mártires Ingleses, Cambridge, Inglaterra. Fotografia A: Lauro K. Dehira.

A pedra se comporta melhor na localidade em que ela foi extraída. A escolha certa da pedra terá influência em seu processo de deterioração, já que o comportamento da pedra será diferente a depender da função que irá desempenhar: estrutural, revestimento, pavimento ou escultura. Superfícies esculpidas exigem maiores cuidados de conservação que superfícies lisas.

Causas de origem antrópica também contribuem para a deterioração das edificações e seus materiais, tais como contato direto de visitantes, negligência/imperícia na prevenção e conservação, disposição do acamamento da pedra no edifício, escolha inadequada de materiais, poluição, vibrações, vandalismo, fogo, guerras e atentados (Figura 4.2).

Para uma adequada resistência estrutural e de resistência frente aos processos de deterioração, a pedra quando for assentada nas edificações deve ser colocada com seu bandamento em posição original na maior parte da obra. Por outro lado, as terminações laterais necessitam que a pedra seja assentada com outras orientações, como mostra a Figura 4.3.

Reys et al. (2008), em avaliação do grau de deterioração de alguns monumentos da cidade de São Paulo, apontam que as ações antrópicas, representadas principalmente por pichações e vandalismo, são fatores marcantes na deterioração desses monumentos, suplantando a deterioração devido às ações intempéricas.

Os reinos animal e vegetal também contribuem na alteração da pedra. Bactérias, cianobactérias, fungos, liquens e plantas superiores são agentes ativos de deterioração e serão discutidos no item 4.2. Pequenos pássaros podem provocar leves danos à pedra com suas bicadas, sendo mais prejudiciais em superfícies esculpidas de pedras brandas. Também o uso como poleiro e ninho pelos pássaros provoca danos principalmente pelo acúmulo de excrementos e materiais do ninho (Figura 4.4). Colmeias também podem danificar a pedra, impregnando-a e a manchando. 

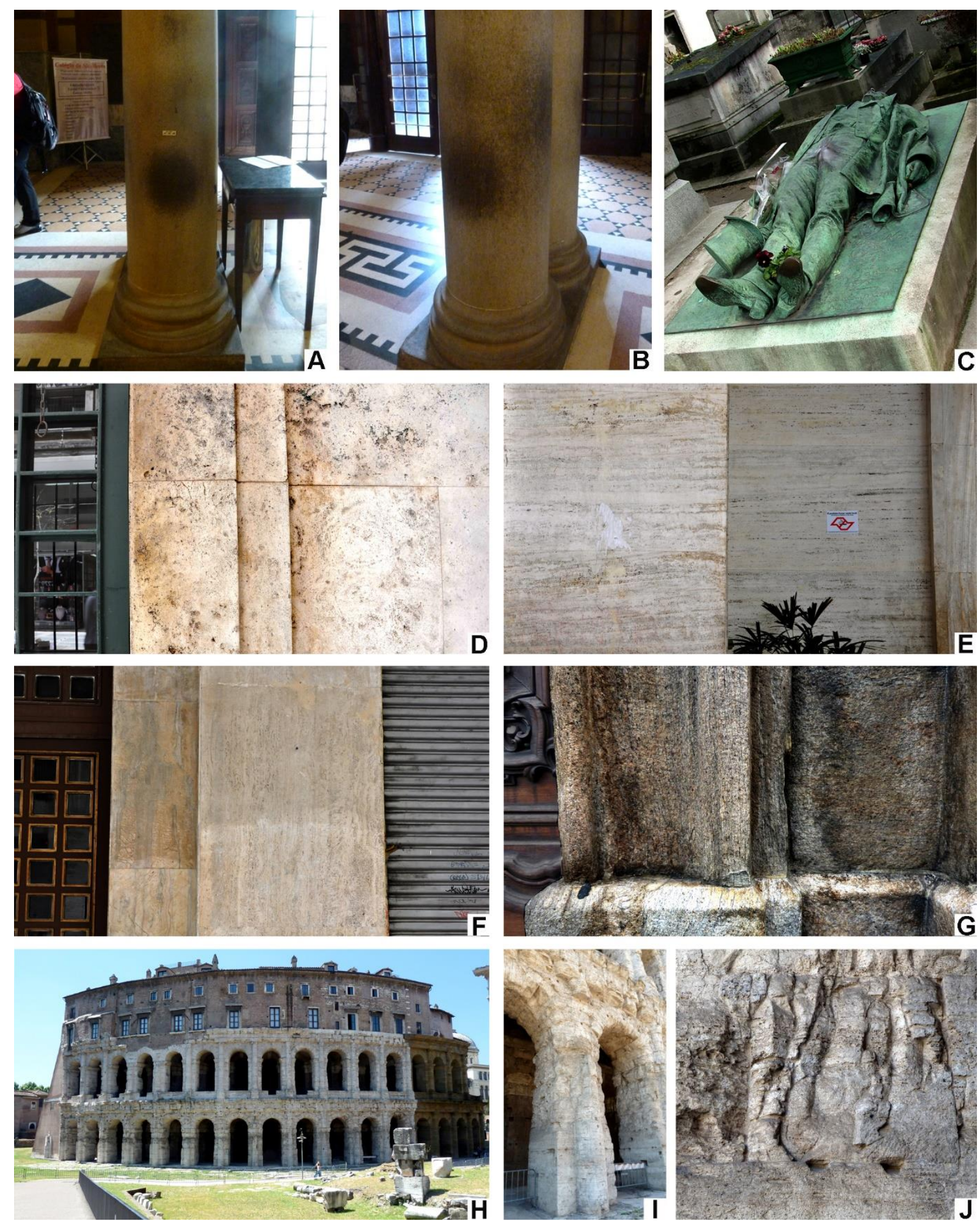

Figura 4.2. Origem antrópica de deterioração. A a C. Contato direto de visitantes. A e B. Marcas de mão e cabeça quando as pessoas se apoiam nas colunas, Mosteiro São Bento, São Paulo. C. Superfície lustrosa devido ao passar a mão constante Cemitério Père-Lachaise, Paris, França. D a G. Disposição da estratificação. D a F. Travertino, São Paulo. D. Corte em planta. E. Estratificação na horizontal. F. Estratificação na vertical. G. Bandamento na vertical, leptinito, Rio de Janeiro. H. Teatro de Marcelo, Roma, Itália. I e J. Detalhe de H. Este teatro já foi incendiado, aparente no estilhaçamento do travertino. Fotografias C a G: Lauro K. Dehira. 


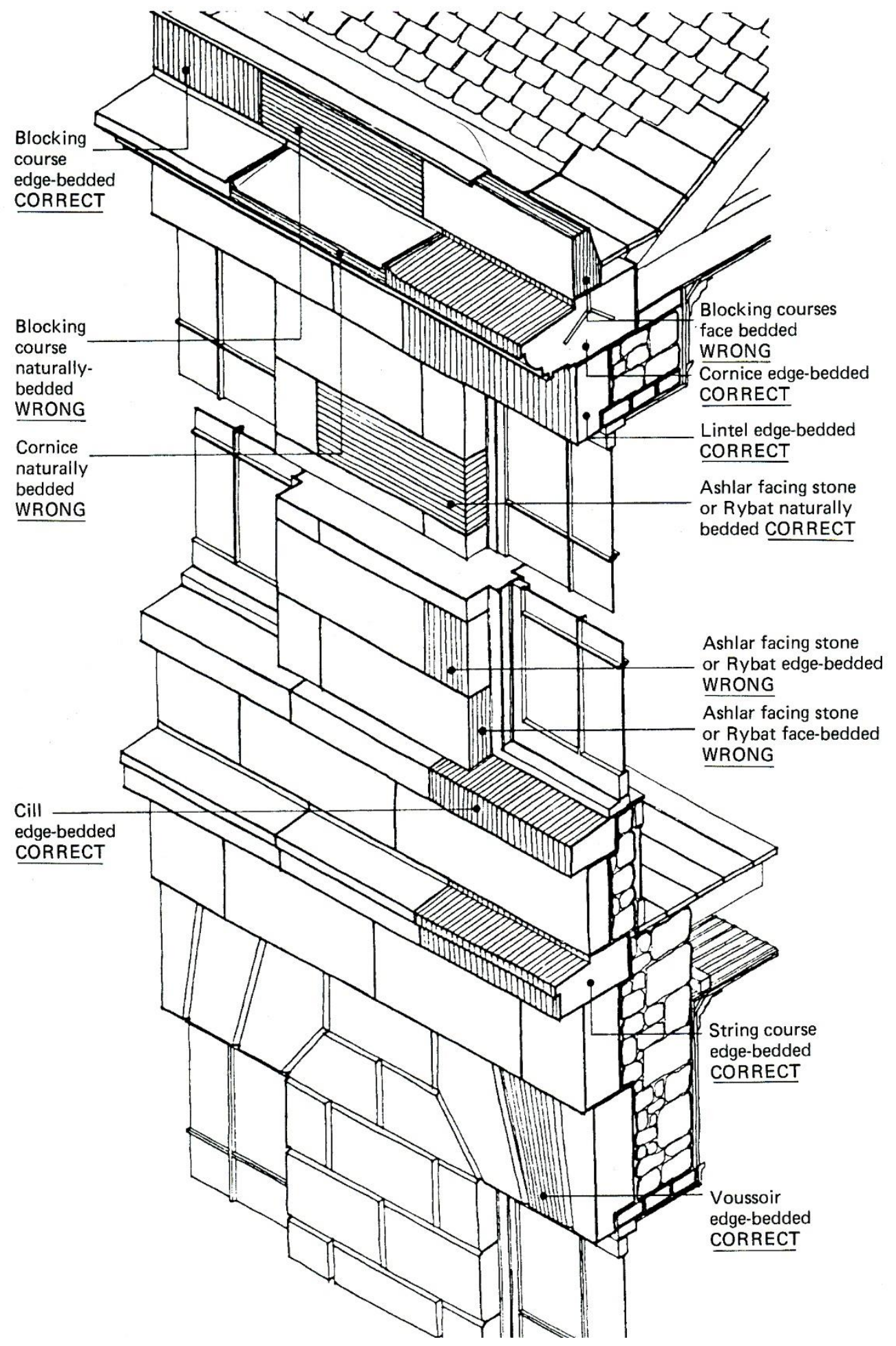

Figura 4.3. Colocação de rochas sedimentares em um edifício. A estratificação deve estar em ângulo reto na direção do esforço. Fonte: Dimes (1990). 

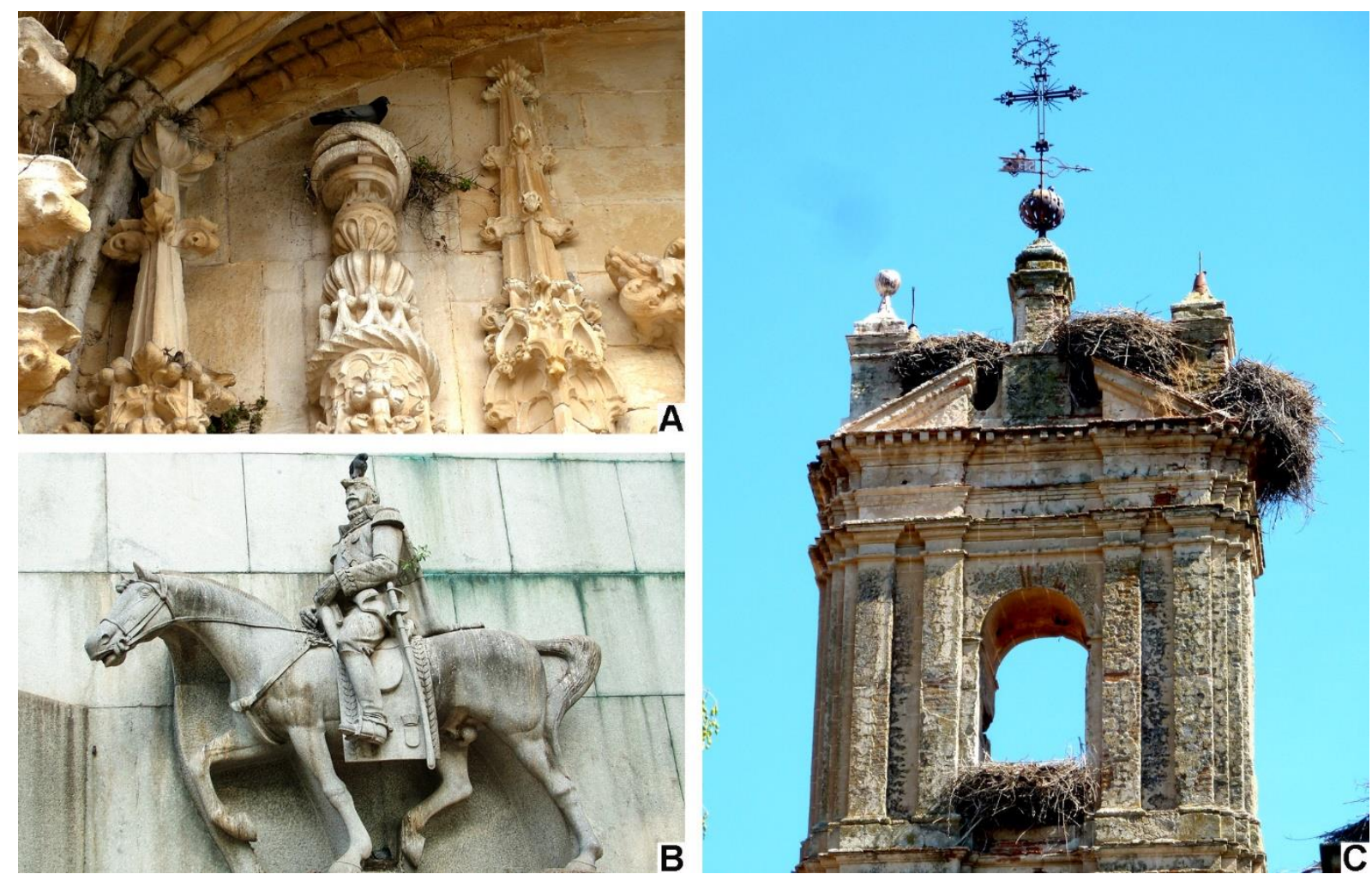

Figura 4.4. Ninhos de pássaro nos monumentos. A. Convento de Cristo, Tomar, Portugal. B. Monumento a Duque de Caxias, São Paulo. Ninho entre as patas do cavalo. C. Cáceres, Espanha.

Para proteger os monumentos dos pássaros, podem ser usados alguns artifícios, tais como: instalação de tela, pontas finas e longas de alumínio ou aço inoxidável, fio elétrico de baixa voltagem, gel, arame de aço inoxidável estirado e com molas nas pontas, e alimentar os pombos com milho coberto com hormônios que induzem a esterilidade, neste caso como medida de diminuição da população das aves. As duas primeiras alternativas são as mais comuns (Figura 4.5).

A proteção aos monumentos (Figura 4.6) pode ser também necessária devido ao clima. Durante o inverno, os monumentos de Salzburgo são cobertos com redomas de vidro ou madeira com as mais diferentes formas, oferecendo um visual bem diferente na cidade. Ou a proteção pode ser também para impedir depredações devido a manifestações populares.

Muitas vezes observa-se prática usada como solução para proteção contra a deterioração a pintura das paredes em pedra, o que obviamente provoca o seu completo mascaramento. Dependendo da porosidade da pedra, dificilmente será possível uma futura remoção dessa pintura (Figura 4.7), o que demonstra que é uma prática errônea, o mais das vezes executada sem nenhuma orientação técnica. 

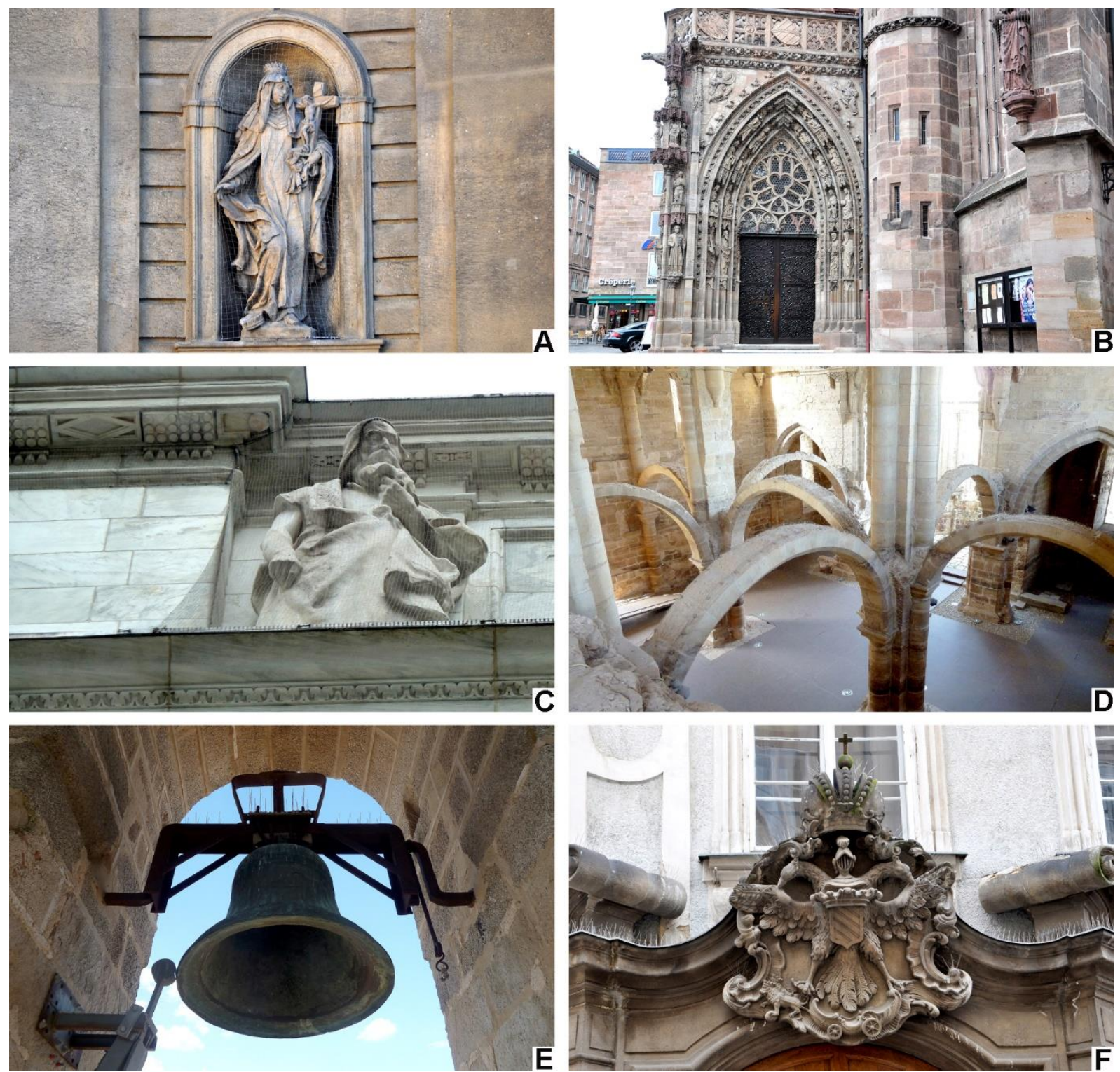

Figura 4.5. Medidas de proteção contra pássaros. A a C. Telas de proteção. A. Praga, República Tcheca. B. Igreja Saint Sebaldo, Nurenberg, Alemanha. C. Biblioteca Pública de Nova York, Estados Unidos. D. Fio elétrico no Mosteiro de Santa Clara, Coimbra, Portugal. E e F. Pontas finas e longas. E. Trujillo, Espanha. F. Praga, República Tcheca. Fotografias A a C e F: Lauro K. Dehira. 

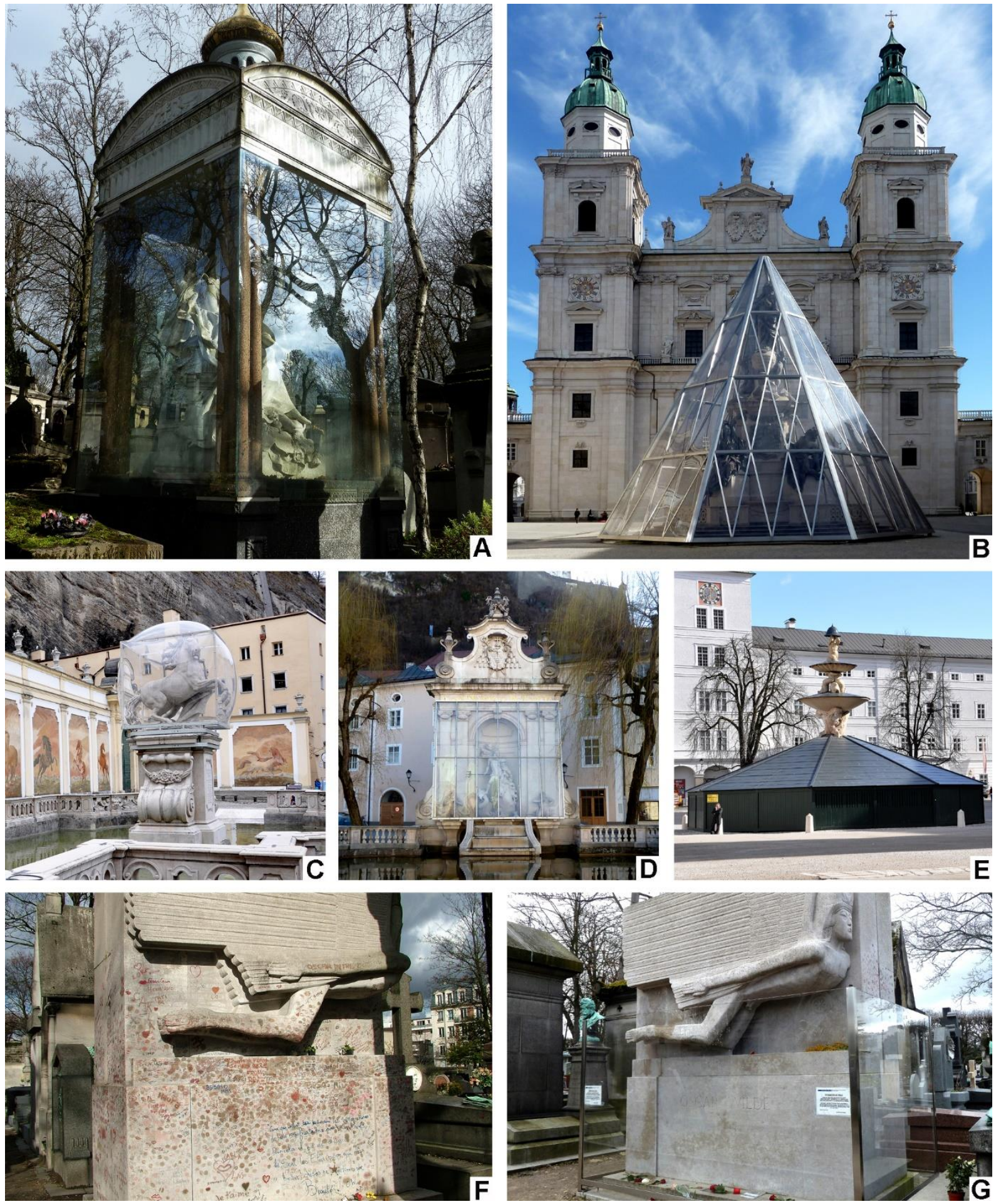

Figura 4.6. A. Jazigo protegido no Cemitério Père-Lachaise, Paris, França. B a E. Monumentos protegidos durante o inverno em Salzburgo, Áustria. F. Jazigo de Oscar Wilde, Cemitério Père-Lachaise, Paris, França. G. Proteção para impedir as manifestações populares. Fotografias: Lauro K. Dehira. 

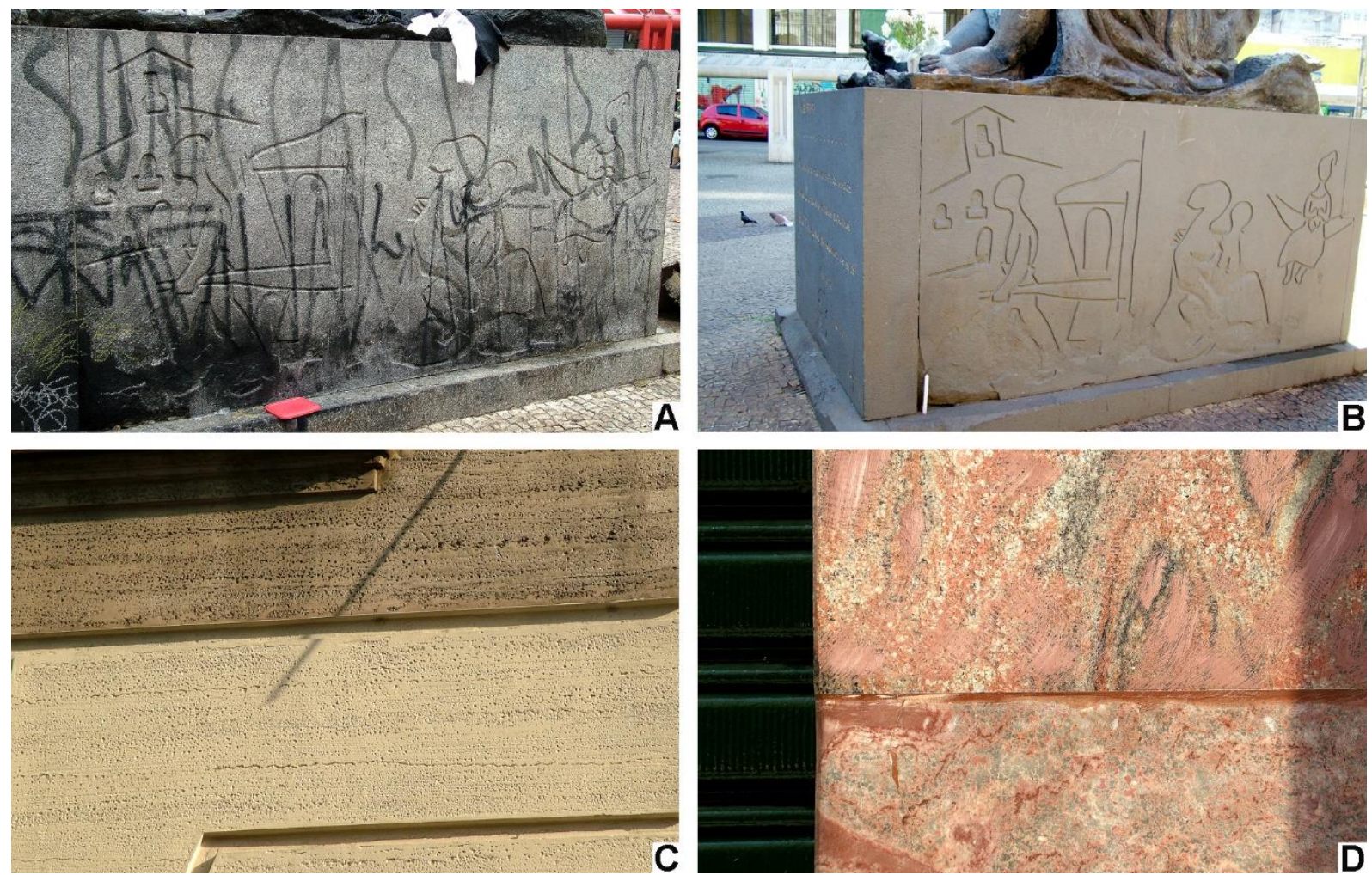

Figura 4.7. Monumentos pintados. A e B. Monumento Mãe Preta, São Paulo. A. Pedestal pichado e queimado por velas na parte inferior. B. Após pintura. C. Travertino pintado em edifício do centro velho de São Paulo. D. Tentativa de imitação do Calcário Sete Lagoas em edifício do centro velho de São Paulo. Fotografias: Lauro K. Dehira.

\subsection{As formas de deterioração}

A deterioração da pedra geralmente é resultado da interação entre os fatores intrínsecos e extrínsecos.

A identificação e caracterização das formas de deterioração são instrumentos de documentação, que indicam os tipos de problemas que ocorrem na pedra, e que devem ser registradas e observadas na fase de diagnóstico de um projeto de conservação e restauro, auxiliando no entendimento do mecanismo que originou estas feições.

$\mathrm{Na}$ literatura especializada existem muitos atlas que ilustram os tipos de alteração da pedra desde a década de 1980. ICOMOS (2008) recupera este histórico e baseado em sete trabalhos (Arnold et al. 1980, Grimmer 1984, Normal 1/88 1990, ICOMOS 1991, Franke et al. 1998, Fitzner \& Heinrichs 2002, Henriques et al. 2005) apresenta uma versão bilíngue inglês- 
francês ricamente ilustrada das formas de deterioração da pedra. Atualmente existem versões desse atlas para os idiomas alemão, tcheco, espanhol, coreano e japonês.

A versão portuguesa já está finalizada aguardando sua publicação. Os termos aqui utilizados são da versão não-oficial da tradução, disponibilizada pelo coordenador José Delgado Rodrigues.

Mas os autores da popularização do uso destes atlas, inclusive no Brasil, foram Fitzner \& Heinrichs (2004) com a publicação do atlas na internet, o que favorece a sua aquisição e consequente utilização. Apesar das ilustrações de 110 formas de alteração neste atlas, com exemplos inclusive do patrimônio brasileiro, a profusão de termos gera dificuldade de utilização. Assim, os trabalhos que utilizavam este atlas referenciavam-no com modificações e adaptações, a exemplo de Silva \& Roeser (2003).

A versão portuguesa de um atlas, elaborada por Henriques et al. (2005), tornou-se mais adequada no sentido de se explicar os termos, com redução considerável do número das formas de deterioração para 28 , desta forma tornando-o mais aplicável para o mapeamento das formas de alteração dos monumentos e edifícios. Silva (2007), Reys et al. (2008) e Del Lama et al. (2008) utilizam este atlas para identificação das formas de alteração, no estudo do pórtico da lgreja do Outeiro da Glória no Rio de Janeiro, nos monumentos da cidade de São Paulo e no mapeamento da fachada frontal do Teatro Municipal de São Paulo, respectivamente.

Trabalhos mais recentes estão utilizando o atlas do ICOMOS (2008), tais como, Grossi \& Del Lama (2012), Kuzmickas (2013), Kuzmickas \& Del Lama (2014), Silva (2014) e Ricardo (2015).

Outros atlas de formas de alteração também estão disponíveis na internet, tais como, o da Queen's University de Belfast, Irlanda, ou da Agência de Patrimônio Cultural da Holanda (MDCS 2015), e que são fontes de consulta para fins de comparação de diferentes formas de deterioração com base em suas ilustrações.

Considerando que o glossário do ICOMOS (2008) é baseado nas principais produções sobre o tema e contou com a participação dos diversos pesquisadores destes trabalhos pioneiros, além de sua acessibilidade facilitada pela internet, recomenda-se com ênfase a sua utilização. O glossário é dividido em 5 grandes grupos (fenda e deformação, destacamento em área, formas devidas à perda de material, alteração cromática e depósito, e colonização biológica) e suas subdivisões, que serão ilustradas nas Figuras 4.8 a 4.24 .

Ressalta-se que a Instrução Normativa n. 1, de 5 de outubro de 2010, do Ministério da Cultura, que estabelece procedimentos para as propostas culturais, lista em seu artigo $7^{\circ}$ os documentos necessários para o cadastramento da proposta. Entre estes, consta na alínea d do inciso XX (que trata de bens imóveis tombados), que deve ser realizado o diagnóstico sobre o estado atual do imóvel contendo informações das causas dos danos, devidamente cotadas.

O mapeamento e a interpretação da ocorrência das formas de deterioração pode auxiliar muito na confecção deste diagnóstico. É um trabalho de observação sistemática que permite ao mapeador conhecer melhor o objeto em estudo. 
Entretanto, a passagem da teoria para a prática nem sempre é tão clara. Alguns termos podem ser ambíguos e refletem em intervenções diferentes (Delgado Rodrigues 2015), necessitando uma sintonia do pesquisador que fez o mapeamento e o conservador que irá intervir na obra. Este autor propõe ainda que seja realizado um mapeamento das entidades de conservação através da identificação de áreas homogêneas para intervenção, complementando a execução de um primeiro mapeamento das formas de alteração. Assim, o mapeamento das formas é mais adequado para identificar as formas de deterioração e entender seus mecanismos, enquanto o mapeamento das entidades é mais adequado no lançamento de concurso ou licitações em projetos de restauro.

Delgado Rodrigues (2015) propõe o seguinte roteiro para a execução de uma intervenção de restauro:

- definir os objetivos e as restrições da intervenção;

- identificar os problemas de conservação;

- descrever, caracterizar e mapear as formas de deterioração;

- interpretar os dados coletados, identificar as causas da deterioração e definir ações de conservação apropriadas;

- dividir o objeto em entidades de acordo com a similaridade das ações de conservação necessárias;

- descrever cada unidade tão detalhada quanto possível em termos de problemas que afetam cada uma delas, e tipificar as ações de conservação esperadas a serem aplicadas para resolver os problemas.

A seguir são apresentadas ilustrações de formas de deterioração segundo a nomenclatura do glossário do ICOMOS (2008).

\subsubsection{Fenda e deformação}

A fenda é subdividida em fratura, fendas em estrela, fissura, craquelê e divisão (Figuras 4.8 e 4.9). Não há subdivisão para deformação.

\subsubsection{Destacamento em área}

O destacamento em área é subdividido em bolha, estalado, delaminação (esfoliação), desagregação (esboroamento e desagregação granular: pulverização, arenização e sugaring), fragmentação (fragmentação em esquírolas e lascagem), destacamento pelicular e destacamento em espessura (descamação e desplacamento contornante: desplacamento) (Figuras 4.10 a 4.12). Os termos em parênteses são uma segunda subdivisão dos termos, podendo haver também uma terceira subdivisão, como no caso da desagregação granular. 

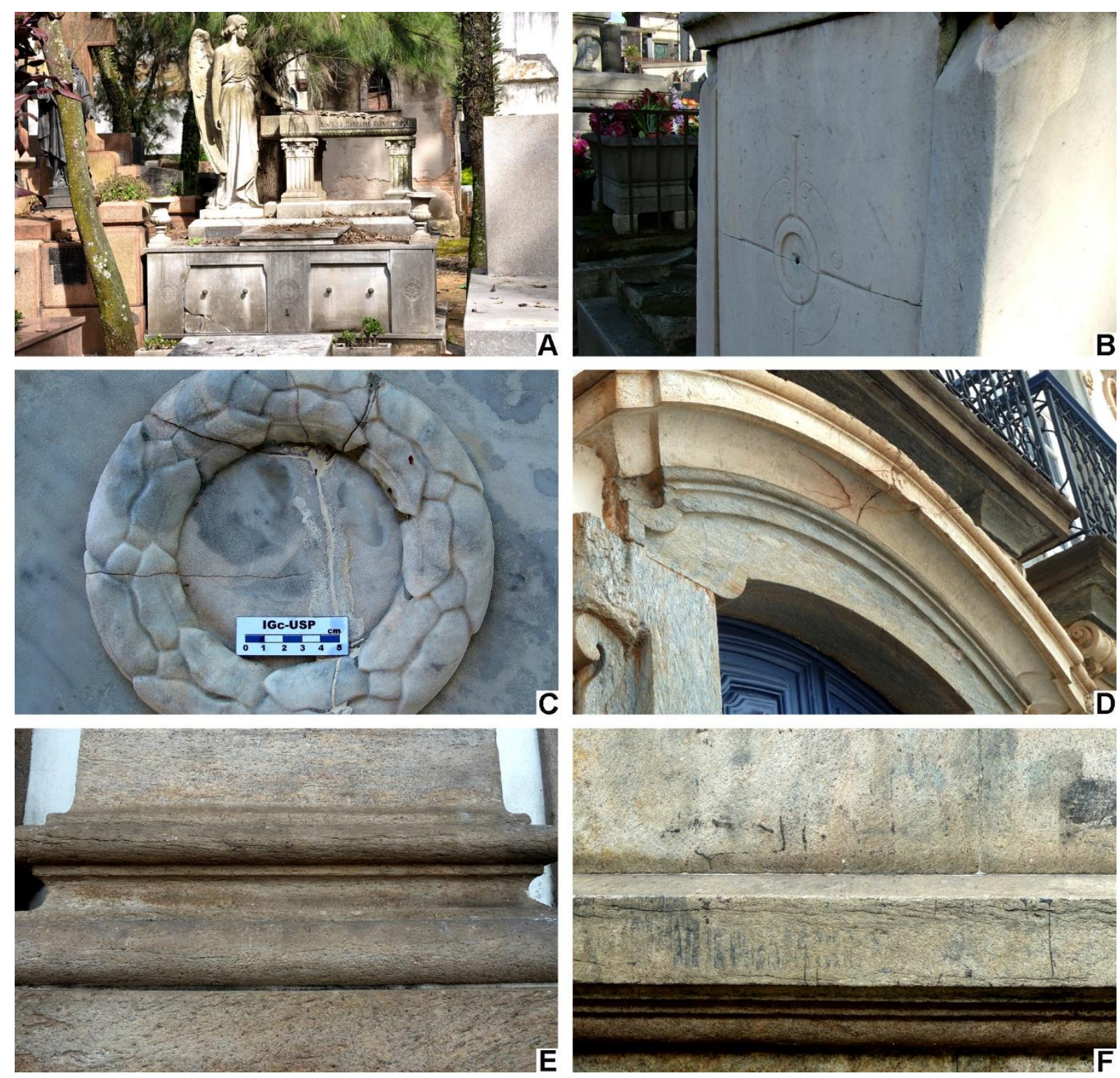

Figura 4.8. Fenda e Deformação. A e B. Fratura em mármore. C e D. Fenda em estrela em mármore e em quartzito. E e F. Fissura em leptinito. A e C: Cemitério da Consolação, São Paulo. B: Cemitério Père-Lachaise, Paris, França. D. Mariana, Minas Gerais. E. Igreja da Candelária, Rio de Janeiro. F: Teatro Municipal do Rio de Janeiro. Fotografias A a C e E: Lauro K. Dehira. 

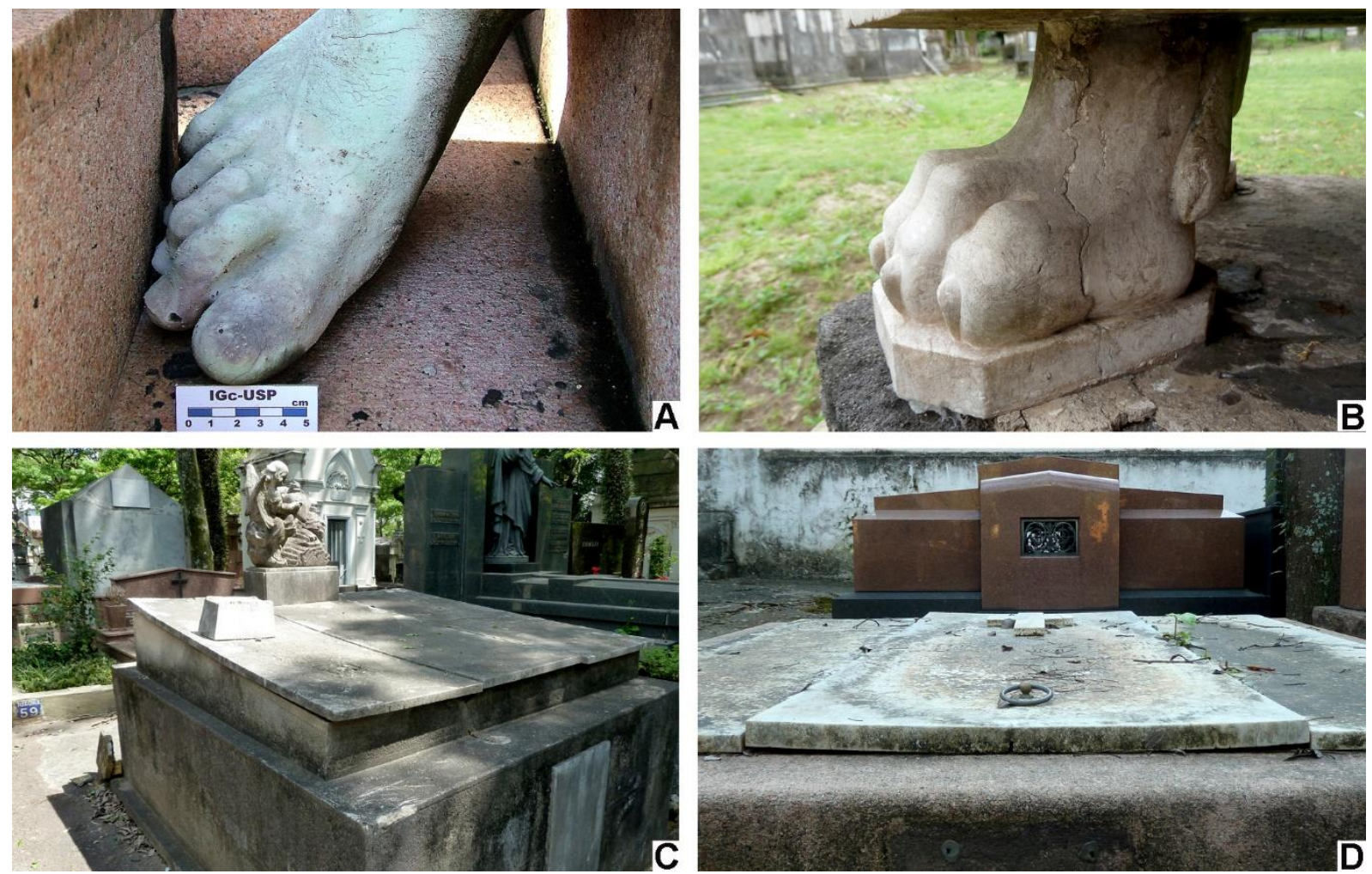

Figura 4.9. Fenda e Deformação. A. Craquelê em mármore. B. Divisão em Lioz. C e D. Deformação em mármore. A, C e D: Cemitério da Consolação, São Paulo. B: Cemitério Nossa Senhora da Soledade, Belém, Pará. Fotografias A, C e D: Lauro K. Dehira.

\subsubsection{Formas devidas à perda de material}

As formas devidas à perda de material são subdivididas em alveolização (escavado), erosão (erosão diferencial: perda de componentes e perda de matriz, arredondamento, aumento da rugosidade), danos de origem mecânica (dano de impacto, incisão, risco, abrasão, apicoado), microcarstificação, lacuna (falta), perfuração e pitting (Figuras 4.13 a 4.16).

\subsubsection{Alteração cromática e depósito}

Alteração cromática e depósito são subdivididos em crosta (crosta negra e crosta de sal), depósito, descoloração (coloração, descoloração, mancha de umidade e mancha), eflorescência, incrustação (concreção), filme, aspecto brilhante, graffiti, pátina (filmes negros e pátina de oxalatos), sujidade e subeflorescência (Figuras 4.17 a 4.20 ).

\subsubsection{Colonização biológica}

Esta forma de deterioração é subdividida em colonização biológica, alga, líquen, musgo, bolor e planta (Figuras 4.21 a 4.24). 

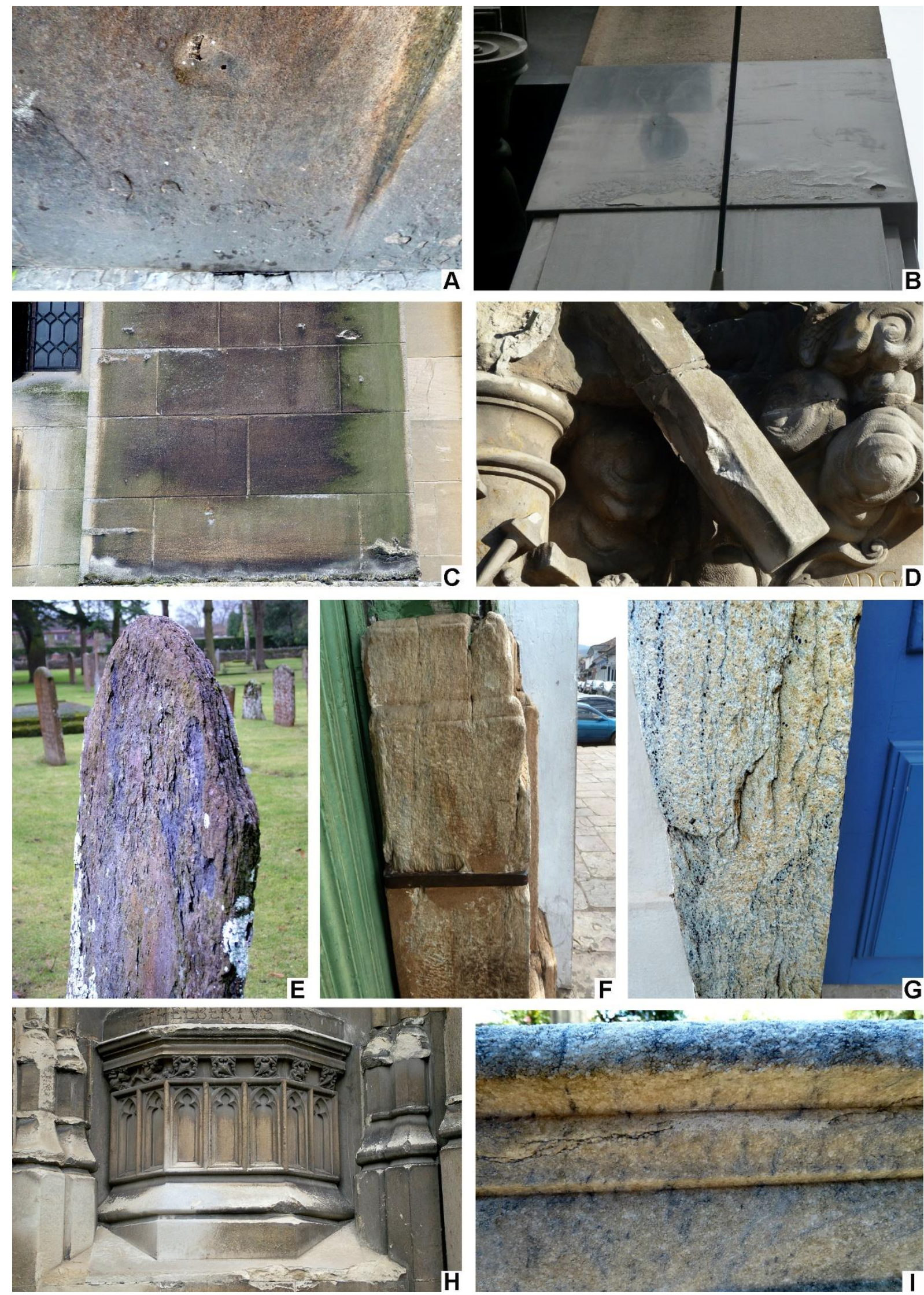

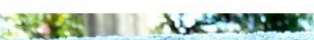

aros

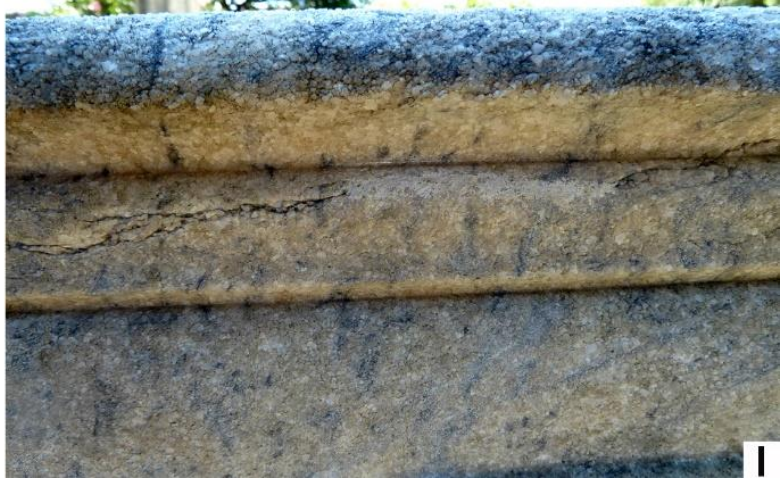

Figura 4.10. Destacamento em área. A. Bolha em leptinito, Teatro Mun. do RJ. B. Bolha em Granito Preto Piracaia, Caixa Cultural, SP. C. Bolha em calcário, Igreja N. S. dos Mártires Ingleses, Cambridge. D. Estalado em arenito, Ponte Carlos, Praga. E. Delaminação em arenito, Stratford-upon-Avon. F. Delaminação em quartzito, Mariana, MG. G. Delaminação em quartzito, Ouro Preto, MG. H. Pulverização em calcário, Canterbury. I. Sugaring em mármore, Cem. Acatólico, Roma. 

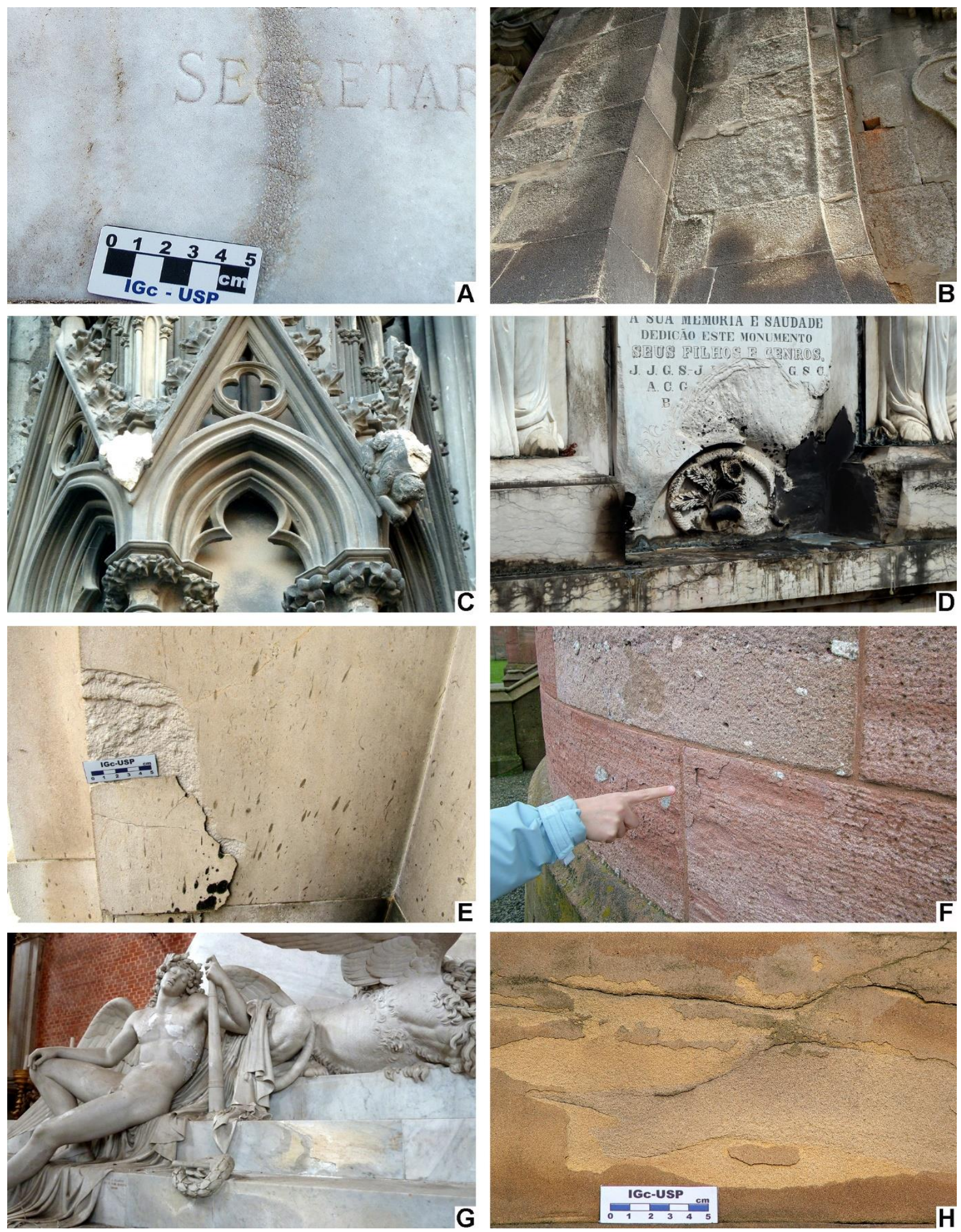

Figura 4.11. Destacamento em área. A. Sugaring em mármore, Jardim da Luz, São Paulo. B. Arenização em granito, Igreja da Lapa, Porto, Portugal. C. Fragmentação em arenito, Catedral de Colônia, Alemanha. D. Fragmentação em Lioz, Cemitério Nossa Senhora da Soledade, Belém, Pará. E. Lascagem em calcário, Cemitério da Consolação, São Paulo. F. Destacamento pelicular em conglomerado, Inverness, Escócia. G. Destacamento pelicular em mármore, Veneza, Itália. H. Destacamento pelicular no Arenito Itararé, Teatro Municipal de São Paulo. Fotografia F: Lauro K. Dehira. 

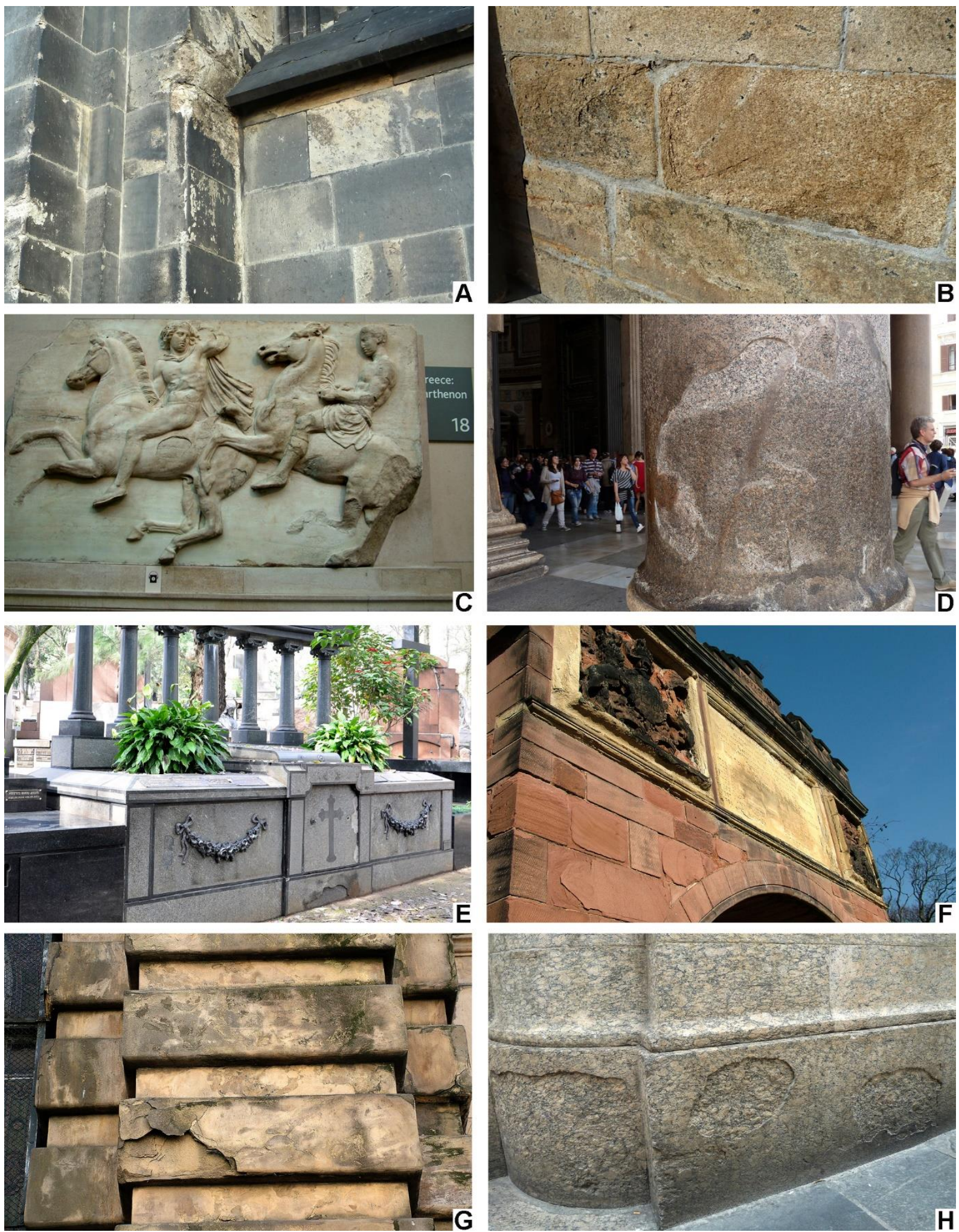

Figura 4.12. Destacamento em área. A. Descamação em traquito, Catedral de Colônia, Alemanha. B. Descamação em granito, Catedral de Salamanca, Espanha. C. Desplacamento contornante em Mármore Pentélico, British Museum, Londres, Inglaterra. D. Desplacamento contornante no Granito del Forum, Pantheon, Roma, Itália. E. Desplacamento no Granito Preto Piracaia, Cemitério da Consolação, São Paulo. F. Desplacamento em arenito, Chester, Inglaterra. G. Desplacamento, Teatro Municipal de São Paulo. H. Desplacamento no Gnaisse Facoidal, prédio do Banco do Brasil, Rio de Janeiro. Fotografias E e F: Lauro K. Dehira. 

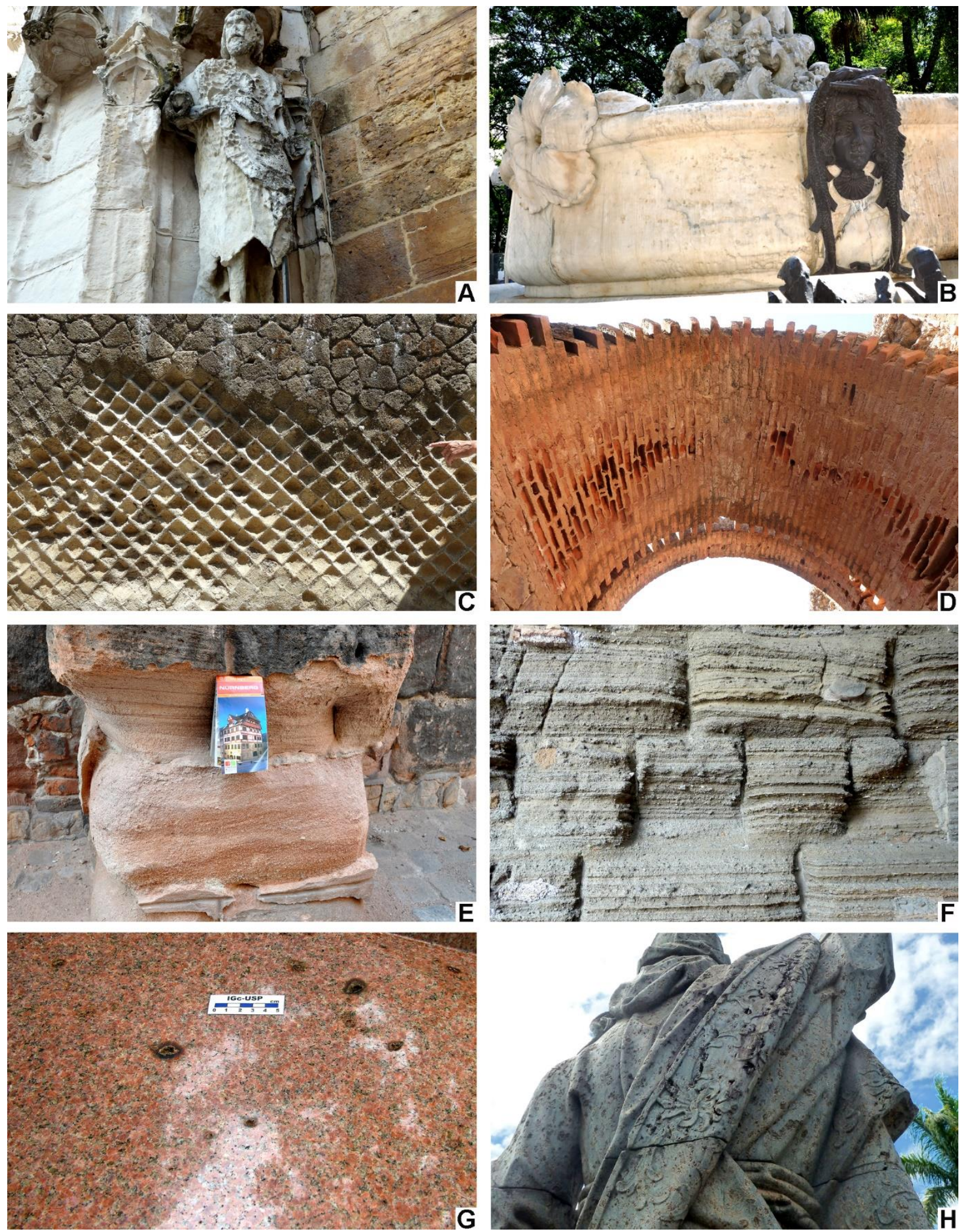

Figura 4.13. Formas devidas à perda de material. A. Alveolização em calcário, Igreja de Santa Cruz, Coimbra, Portugal. B. Alveolização em mármore, Fonte Monumental, São Paulo. C. Escavado em tufo vulcânico, Herculano, Itália. D. Escavado em Mérida, Espanha. E. Erosão diferencial em arenito, Nurenberg, Alemanha. F. Erosão diferencial em tufo vulcânico,

Museu Capitolino, Roma, Itália. G. Perda de componentes no Granito Itupeva, Cemitério da Consolação, São Paulo. H. Perda de componentes em esteatito, Congonhas, Minas Gerais. Fotografias E e G: Lauro K. Dehira. 

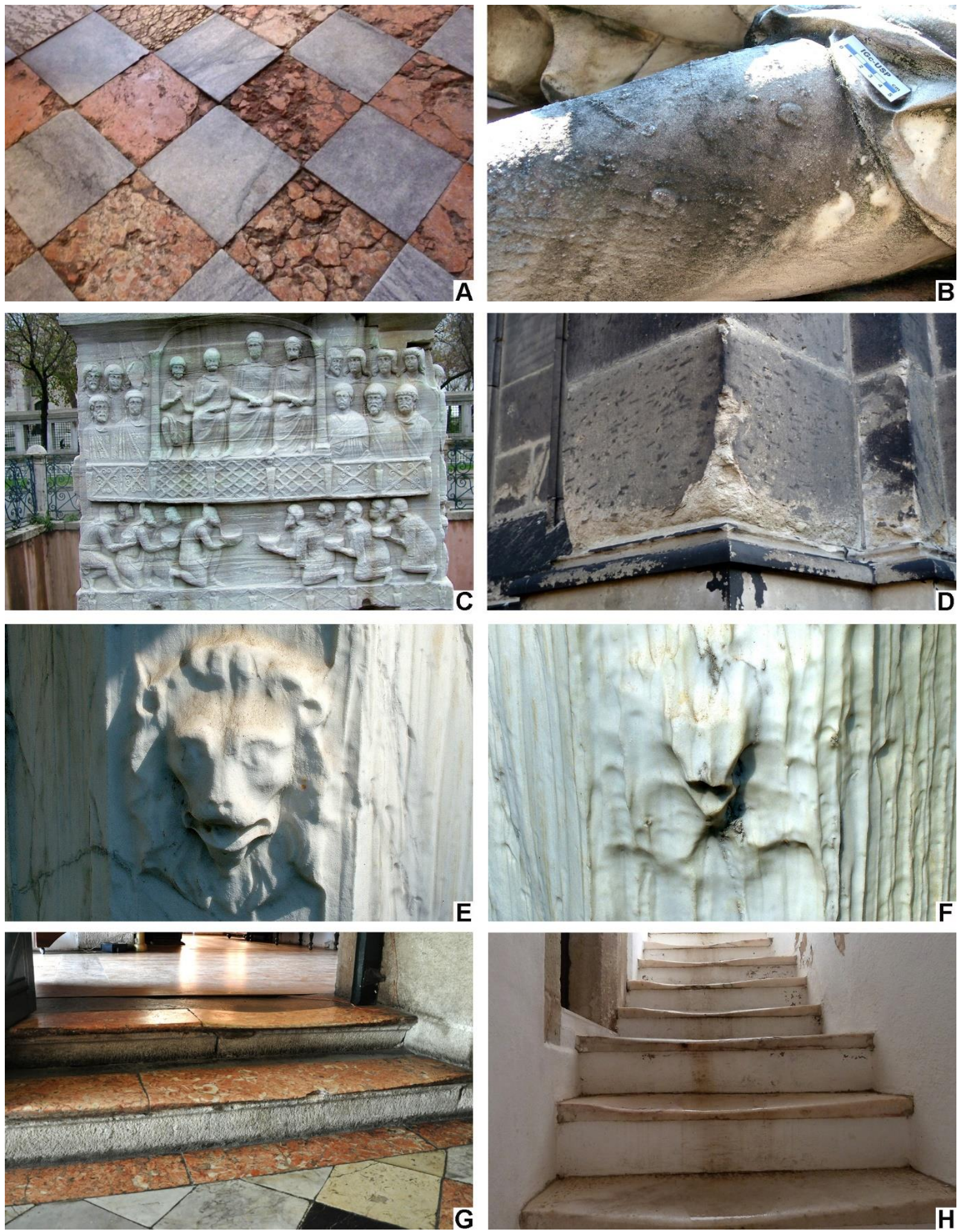

Figura 4.14. Formas devidas à perda de material. A. Perda de matriz em Lioz, Sé do Porto, Portugal. B. Aumento de rugosidade em mármore, Cemitério da Consolação, São Paulo. C. Arredondamento em mármore, base do Obelisco Egípcio, Istambul, Turquia. D. Arredondamento em traquito, Catedral de Colônia, Alemanha. E. Arredondamento em mármore, Jardim da Luz, São Paulo. F. Outra face da fonte de E, em estágio de erosão mais avançado pelo maior escorrimento de água. G. Abrasão em Lioz, Catedral de Salvador, Bahia. H. Abrasão em mármore, Estremoz, Portugal. Fotografias A a C e G: 

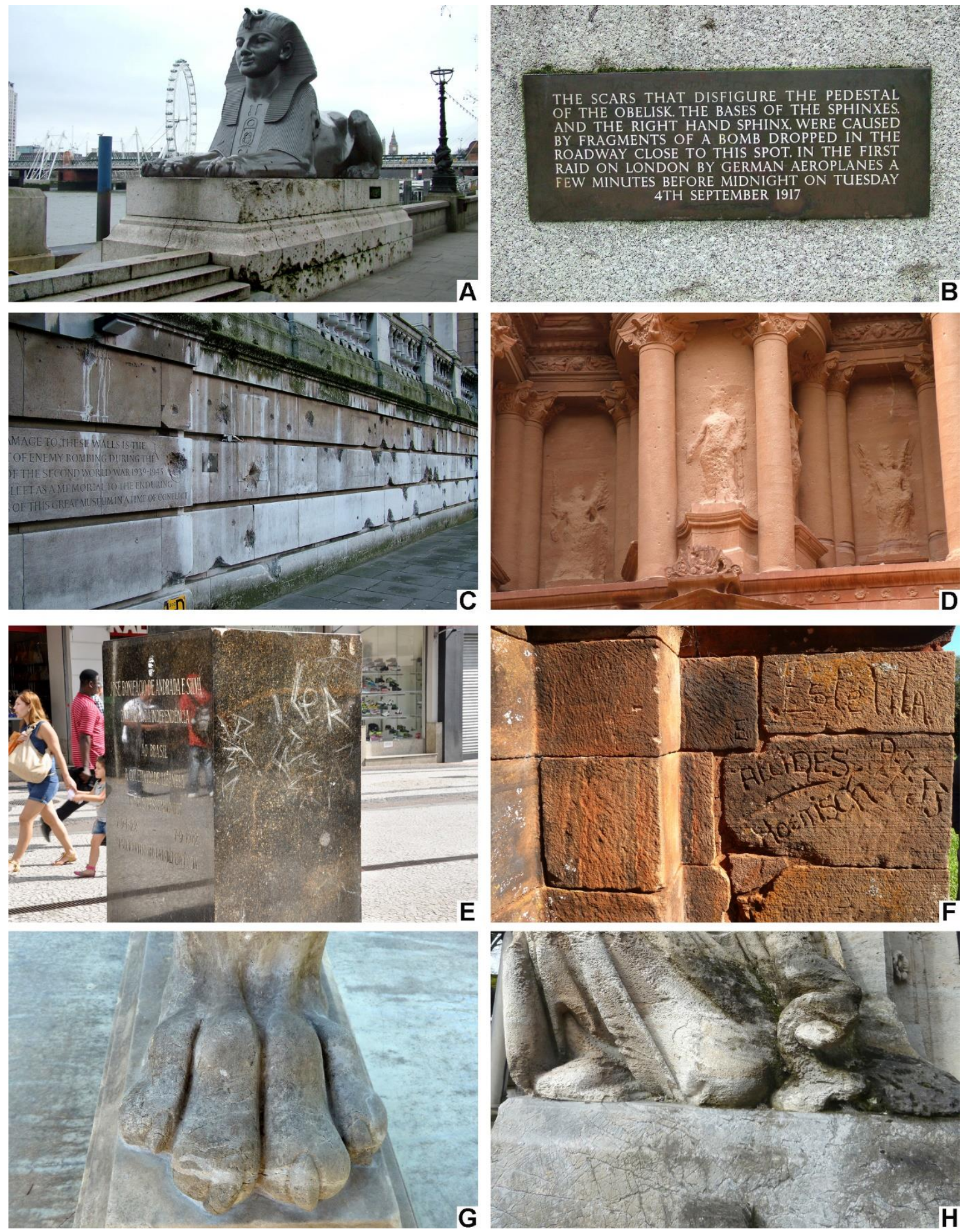

Figura 4.15. Formas devidas à perda de material. A. Dano de impacto em granito devido à bomba, Londres, Inglaterra. B Placa de explicação de A. C. Dano de impacto em granito devido à bomba, Victoria and Albert Museum, Londres, Inglaterra.

D. Dano de impacto em arenito devido à artilharia, Petra, Jordânia. E. Risco em Granito Ubatuba, Monumento a José

Bonifácio, São Paulo. F. Risco em arenito, São Miguel das Missões. G. Microcarstificação em calcário, Cemitério Acatólico, Roma, Itália. H. Microcarstificação em calcário, Cemitério Père-Lachaise, Paris, França. Fotografias A, B, D, E e H: Lauro K. Dehira. 

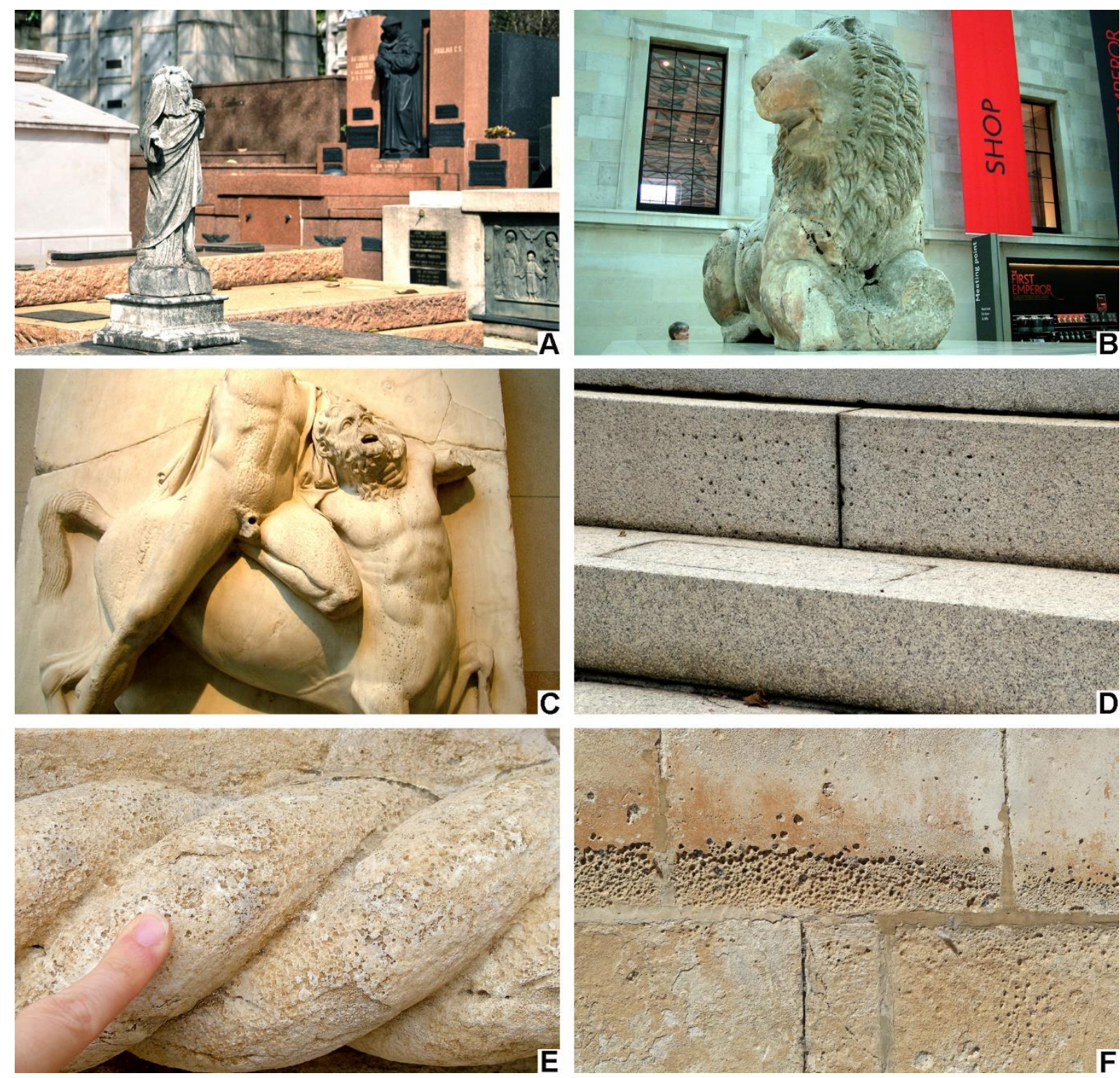

Figura 4.16. Formas devidas à perda de material. A. Lacuna em mármore, Cemitério da Consolação, São Paulo. B. Falta em mármore, Leão de Knidos, British Museum, Londres, Inglaterra. C. Perfuração em Mármore Pentélico, British Museum, Londres, Inglaterra. D. Perfuração em Granito Cinza Mauá, Cemitério da Consolação, São Paulo. E. Pitting em calcário, Mosteiro dos Jerónimos, Lisboa, Portugal. F. Pitting em calcário, Mosteiro de Batalha, Portugal. Fotografia A: Lauro K. Dehira. 

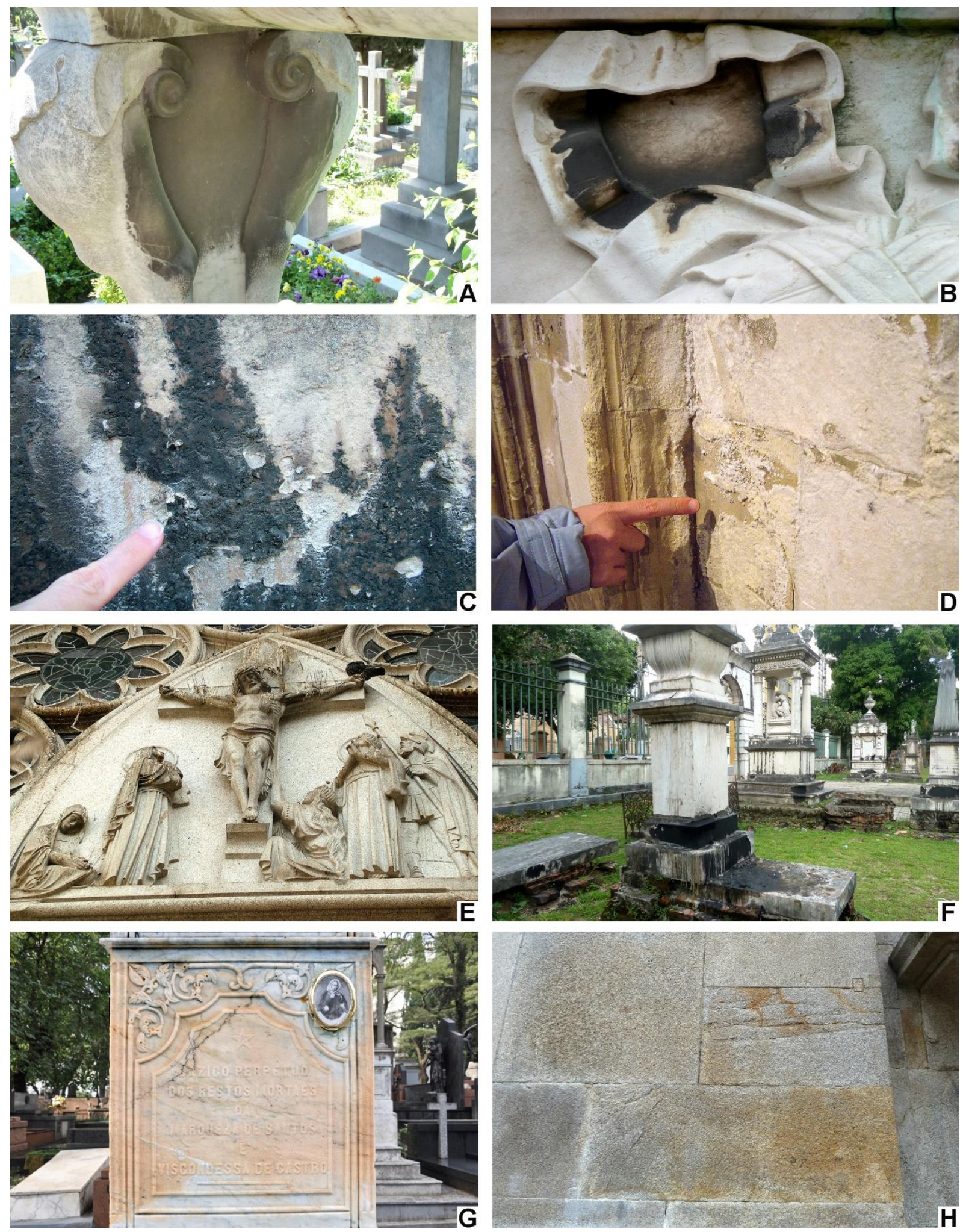

Figura 4.17. Alteração cromática e depósito. A. Crosta negra em calcário, Cemitério Acatólico, Roma, Itália. B. Crosta negra em mármore, Cemitério Agramonte, Porto, Portugal. C. Crosta negra em calcário, King College, Cambridge, Inglaterra. D.

Crosta de sal em calcário, York Minster, Inglaterra. E. Depósito, Sé de São Paulo. As pontas não foram suficientes para proteger a igreja dos pombos. F. Depósito de fuligem e cera, Cemitério Nossa Senhora da Soledade, Belém, Pará. G. Coloração em mármore, Cemitério da Consolação, São Paulo. H. Coloração em granito, Cemitério Prado do Repouso, Porto, Portugal. Fotografias C a E: Lauro K. Dehira. 

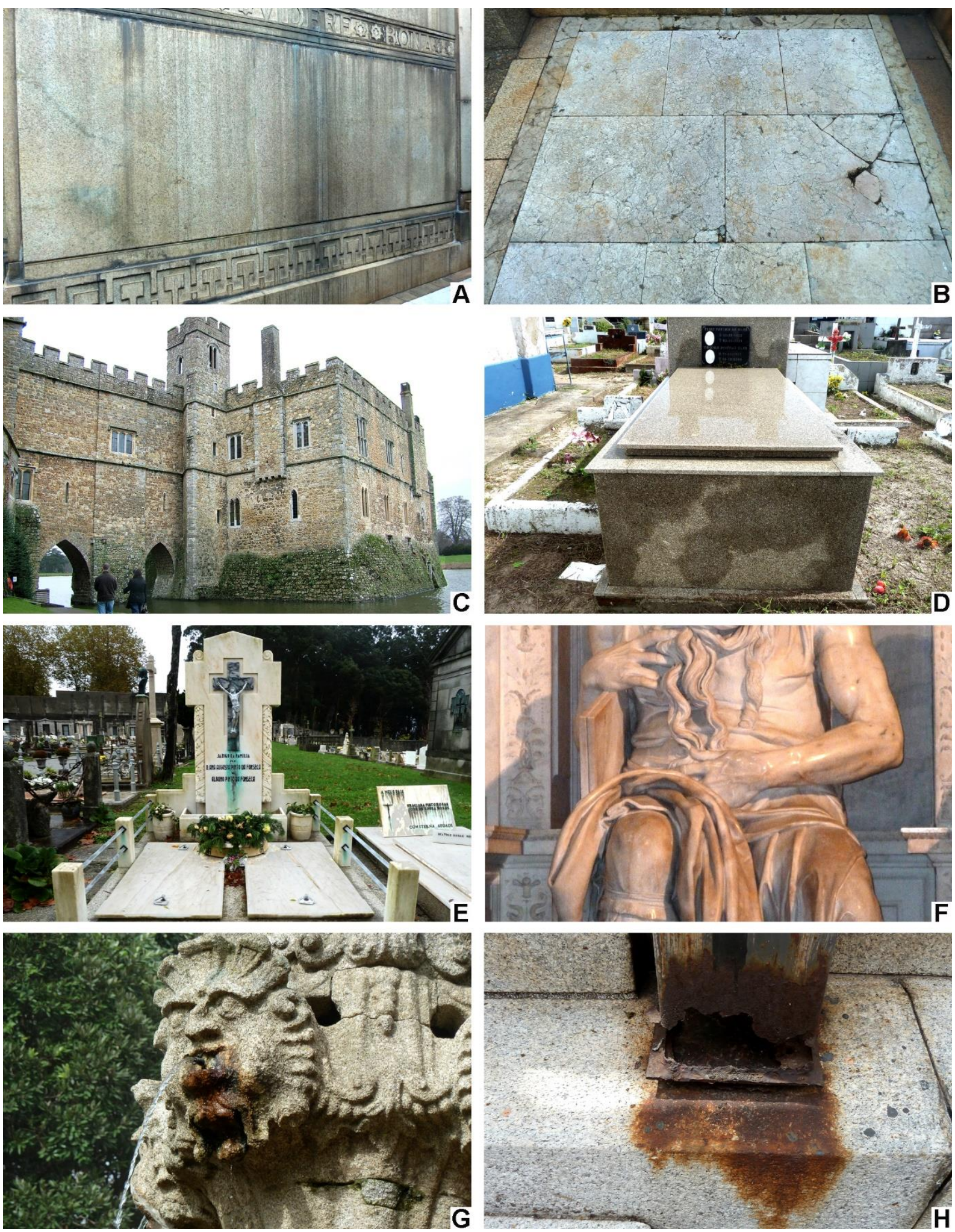

Figura 4.18. Alteração cromática e depósito. A. Descoloração em granito rosa, Cemitério da Consolação, São Paulo. B. Descoloração no Rosso Verona, Cemitério da Consolação, São Paulo. C. Mancha de umidade, Castelo de Leeds, Inglaterra. D. Mancha de umidade em granito, Cemitério de Iguape, São Paulo. E. Mancha em mármore, Cemitério Prado do Repouso, Porto, Portugal. F. Mancha em mármore, Igreja San Pietro in Vincoli, Roma, Itália. Anteriormente se usava cera para polir estátuas nas igrejas, sendo que muitas delas ficaram impregnadas. Estátua Moisés de Michelangelo. G. Mancha em granito,

Porto, Portugal. H. Mancha no Granito Itaquera, Igreja do Carmo, São Paulo. 

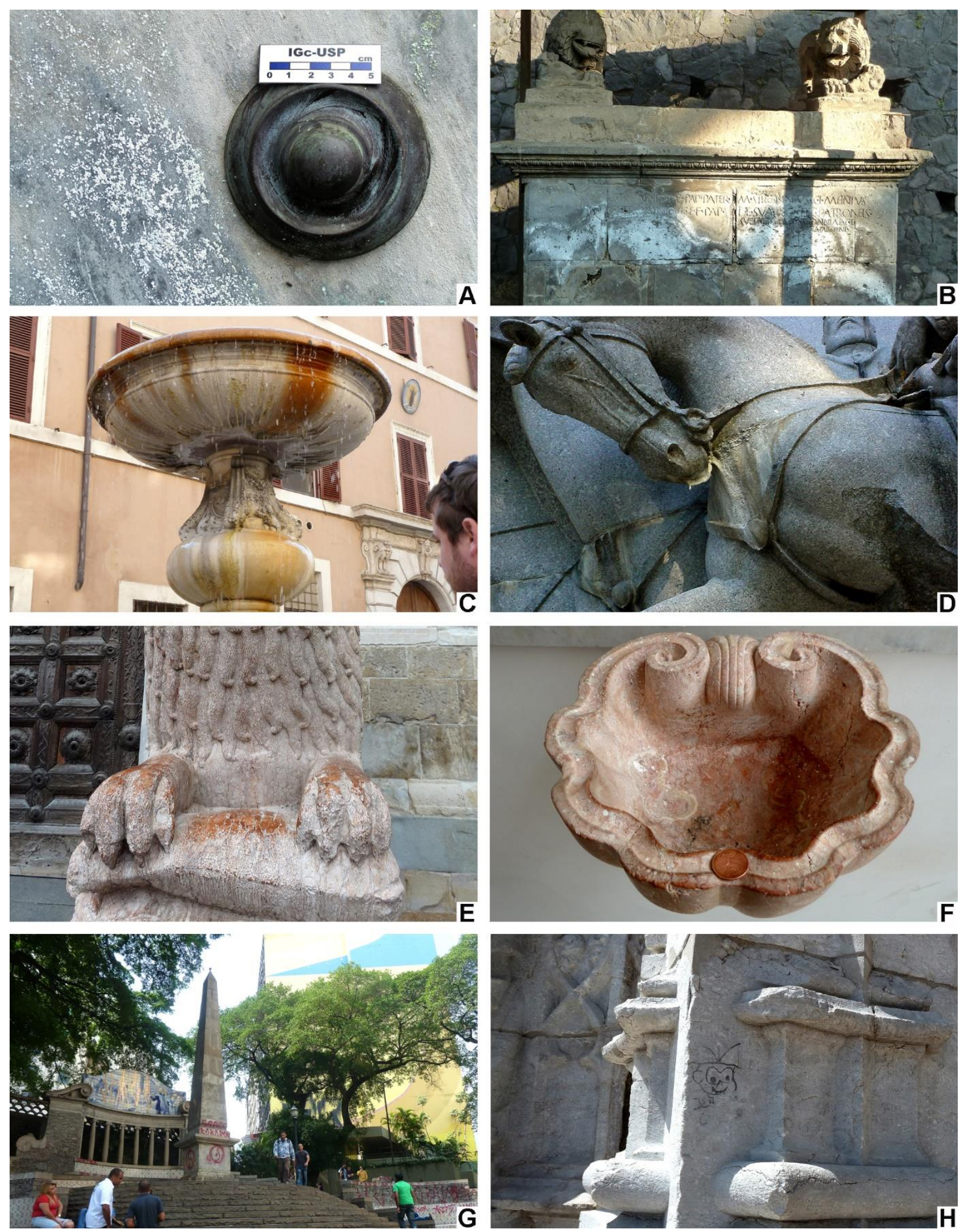

Figura 4.19. Alteração cromática e depósito. A. Eflorescência em mármore, Cemitério da Consolação, São Paulo. B. Eflorescência em jazigo, Pompeia, Itália. C. Incrustação em mármore, Piazza di Campitelli, Roma, Itália. D. Concreção no Granito Cinza Mauá, Monumento a Duque de Caxias, São Paulo. E. Aspecto brilhante no Rosso Verona, Catedral de Parma, Itália. F. Aspecto brilhante no Lioz, Igreja do Carmo, São Paulo. G. Graffiti no Granito Itaquera, Obelisco da Memória, monumento mais antigo da cidade de São Paulo. H. Graffiti em Lioz, Mosteiro dos Jerónimos, Lisboa, Portugal. 

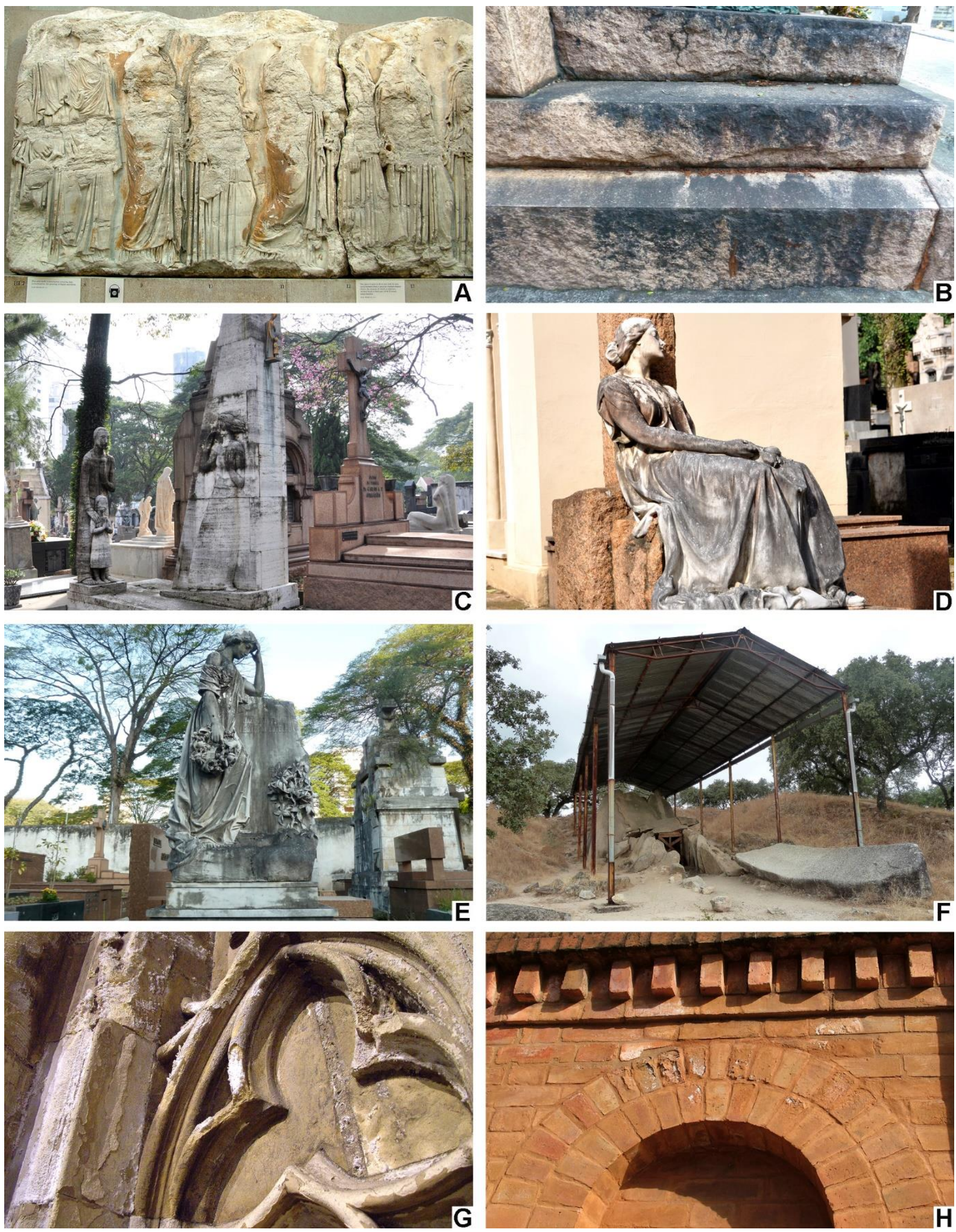

Figura 4.20. Alteração cromática e depósito. A. Pátina em Mármore Pentélico, British Museum, Londres, Inglaterra. B. Filme negro em granito, Cemitério da Consolação, São Paulo. C. Sujidade em travertino, Cemitério da Consolação, São Paulo. D. Sujidade em mármore, Cemitério da Consolação, São Paulo. E. Sujidade em mármore, Cemitério da Consolação, São Paulo. F. Sujidade em granito, Anta Grande do Zambujeiro, Évora, Portugal. A parte suja é a que ficou desprotegida. G. Subeflorescência em calcário, York Minster, Inglaterra. H. Subeflorescência em tijolo, Estação da Luz, São Paulo. Fotografias C, D, G e H: Lauro K. Dehira. 

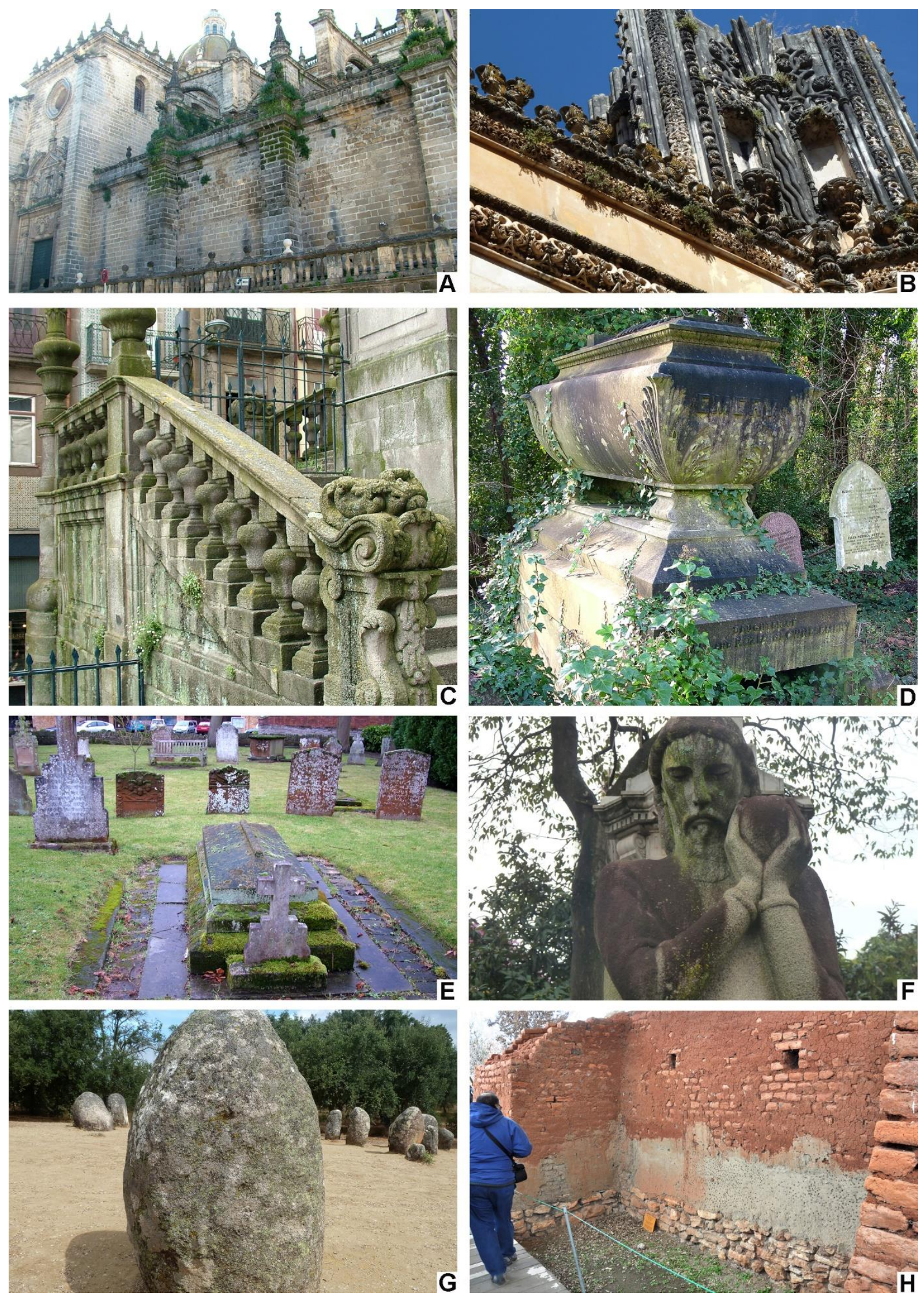

Figura 4.21. Colonização biológica. A. Planta, musgo e alga no Alcázar de Jerez. B. Planta e líquen em calcário, Most. de Batalha. C. Planta, alga e musgo em granito, Ig. dos Clérigos, Porto. D. Planta, alga e líquen, Cem. Highgate, Londres. E. Planta, musgo e líquen, Stratford-upon-Avon. F. Alga e líquen no Gr. Itaquera, Cem. da Consolação, SP. G. Líquen e musgo em granito, Cromeleque dos Almendres, Évora. H. Colon. Biol. em argamassa colocada para proteger a parede, Troia. 

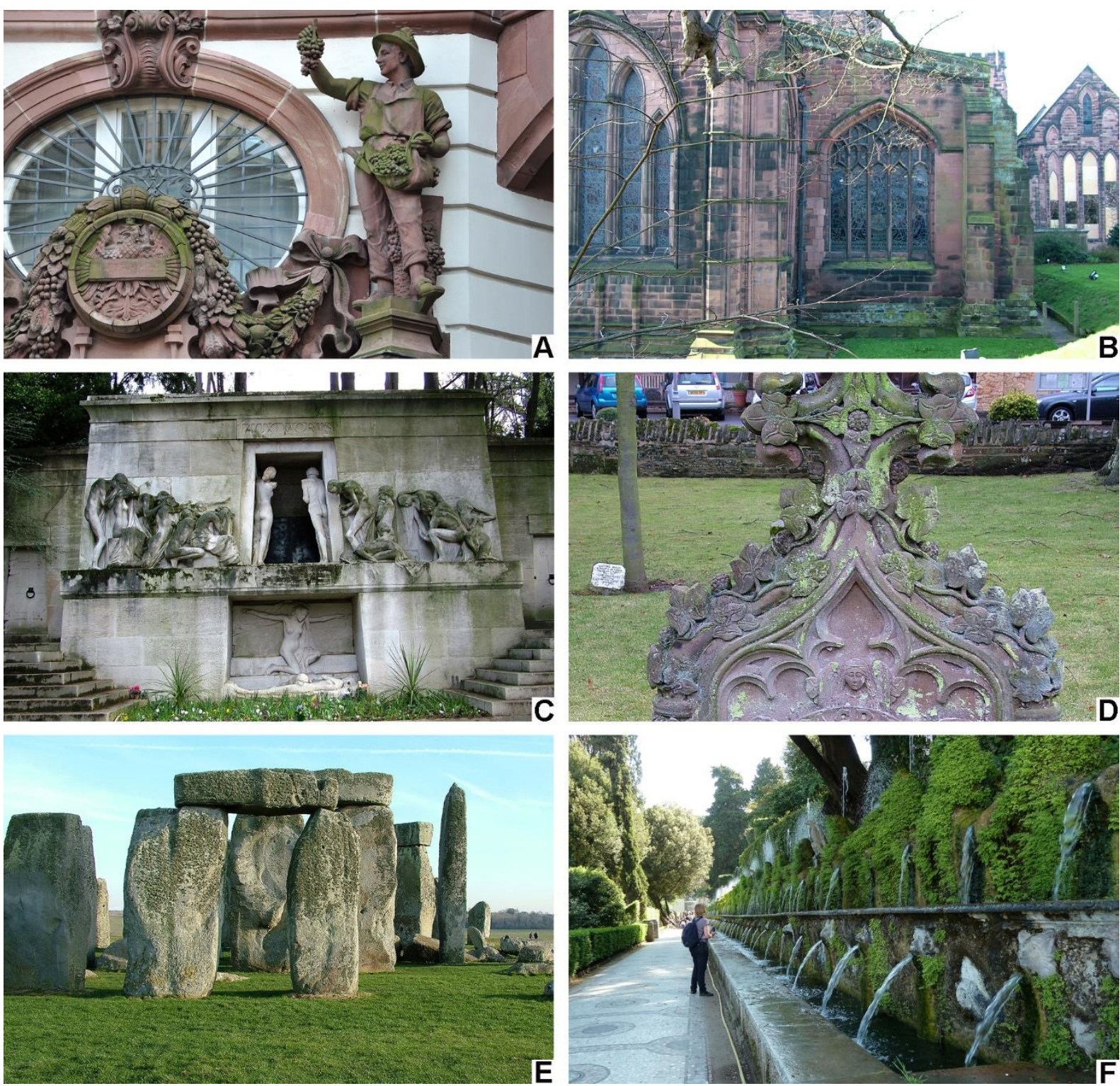

Figura 4.22. Colonização biológica: algas e musgo. A. Alga em arenito, Frankfurt, Alemanha. B. Alga em arenito, Chester, Inglaterra. C. Alga em mármore, Cemitério Père-Lachaise, Paris, França. D. Alga em arenito, Stratford-upon-Avon, Inglaterra. E. Musgo em arenito, Stonehenge, Inglaterra. F. Musgo, Vila D’Este, Tívoli, Itália. Fotografias A, B e E: Lauro K. Dehira. 

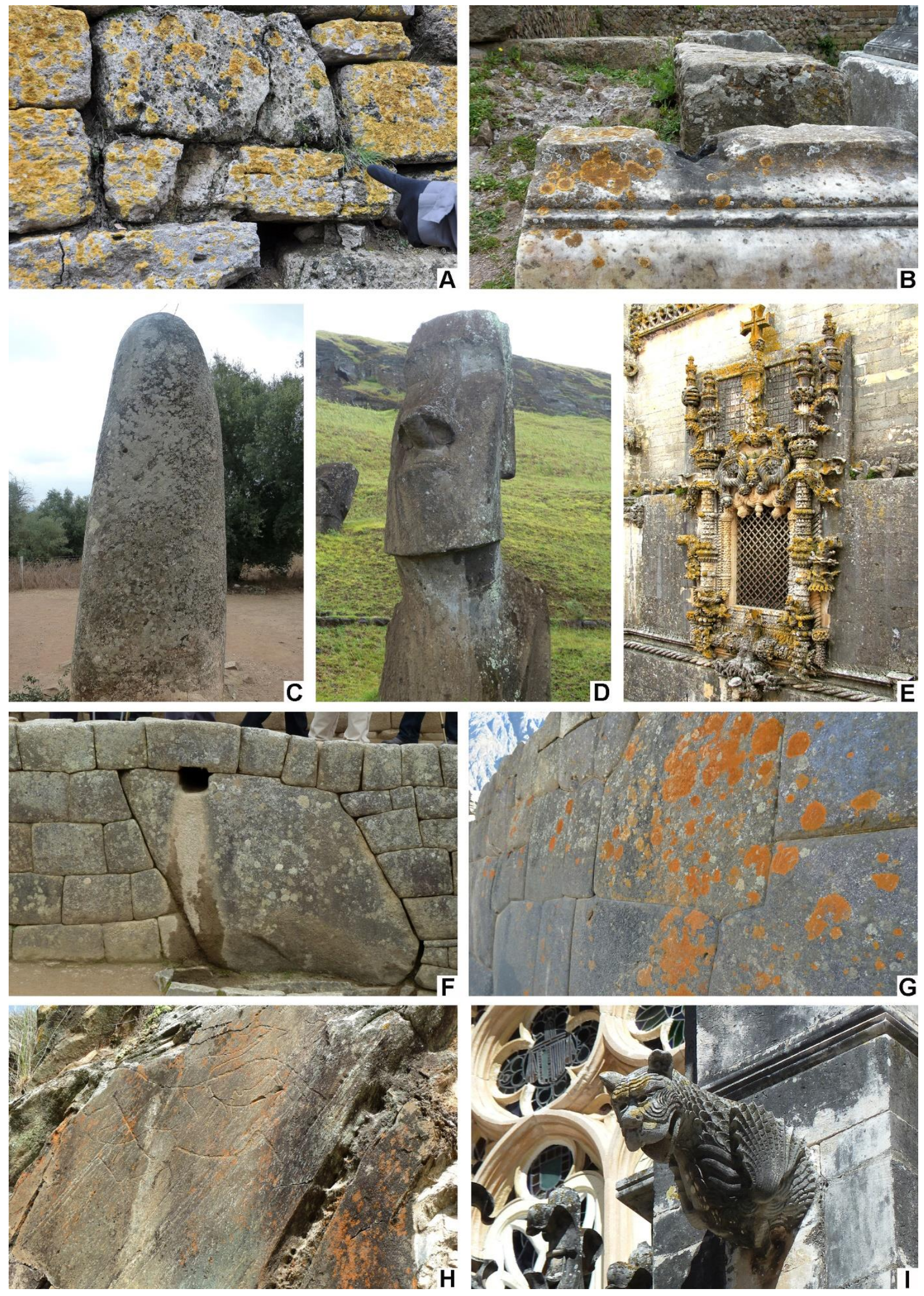

Figura 4.23. Colonização biológica: liquens. A. Mármore, Troia, Turquia. B. Mármore, Ostia Antica, Itália. C. Granito, Menhir dos Almendres, Évora, Portugal. D. Tufo vulcânico, Ilha de Páscoa, Chile. E. Calcário, Convento de Cristo, Tomar, Portugal. F. Granito, Machu Picchu, Peru. G. Granito, Ollantaytambo, Peru. H. Filito, Vale do Côa, Portugal. I. Calcário, Mosteiro da Batalha, Portugal. Fotografia A: Lauro K. Dehira. 

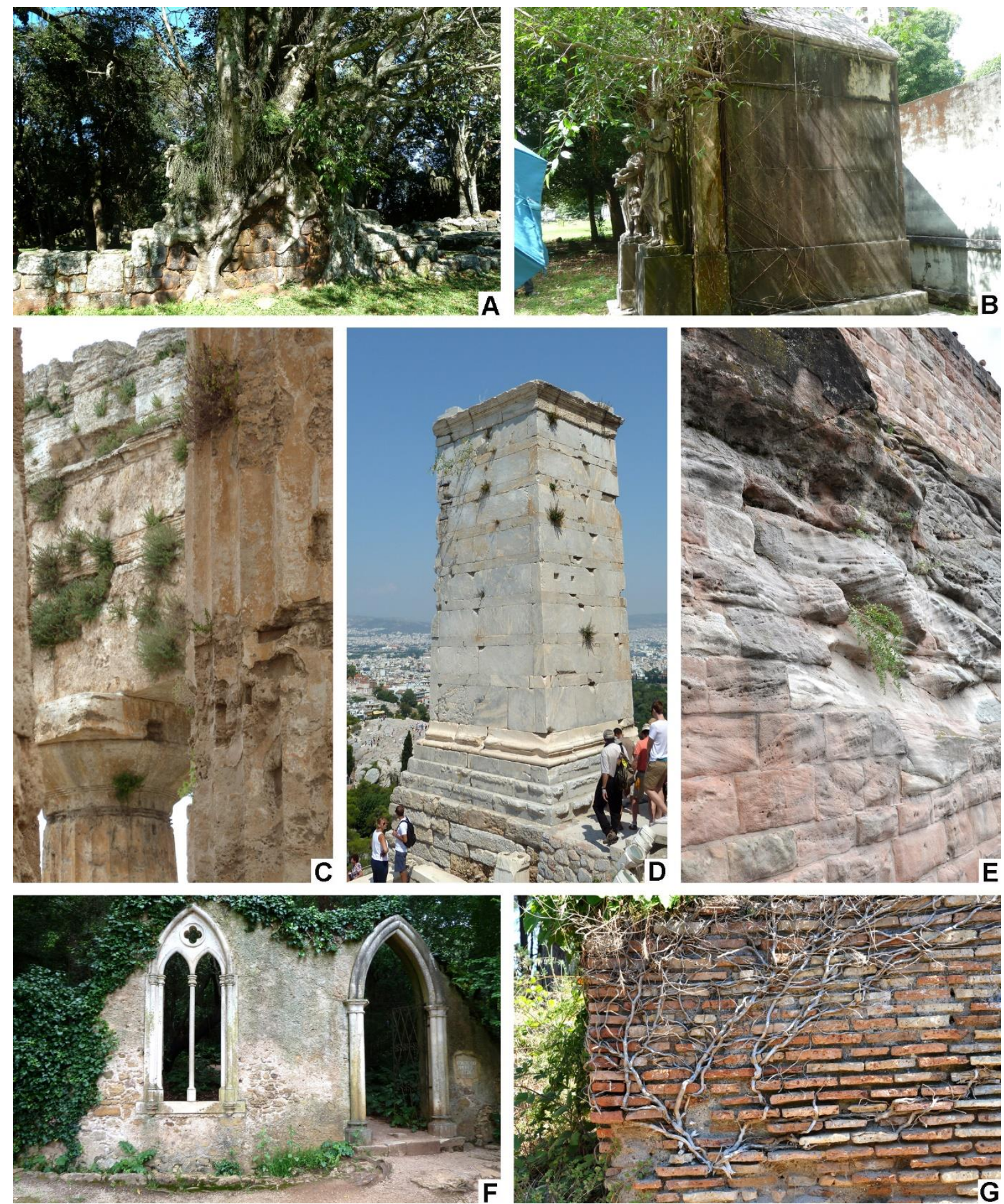

Figura 4.24. Colonização biológica: plantas. A. São Miguel das Missões, Rio Grande do Sul. B. Cemitério Nossa Senhora da Soledade, Belém, Pará. C. Paestum, Itália. D. Acrópoles, Atena, Grécia. E. Castelo Imperial de Nurenberg, Alemanha. F. Fonte dos Amores, Coimbra, Portugal. G. Ostia Antica, Itália. Fotografias A, C, E e G: Lauro K. Dehira. 


\subsection{Biodeterioração}

Biodeterioração pode ser definida por qualquer mudança nas propriedades de um material causada por atividades de organismos vivos, representados por algas, liquens, musgos e plantas vasculares.

Bactérias e fungos podem ser encontrados quando há um acúmulo de nutrientes orgânicos resultante de partículas atmosféricas, resíduos ou prévia colonização biológica, ou de restauração (tratamentos fazendo uso de resinas orgânicas, colas ou ligantes).

Geralmente, os grupos mais relevantes da biodeterioração são os autótrofos, ou seja, aqueles capazes de sintetizar seu próprio alimento.

As condições ambientais contribuem consideravelmente para o ataque biológico, já que parâmetros ambientais, tais como água, temperatura e luz, condicionam o crescimento de diferentes espécies.

Os micro-organismos litobiônticos são agentes de degradação, pois podem penetrar até $15 \mathrm{~mm}$ na rocha, mas geralmente penetram até 2-3 $\mathrm{mm}$ da superfície; e o dano depende do tipo de fixação do micro-organismo, das espécies envolvidas e do tipo de substrato.

O desenvolvimento de micro-organismos na pedra dá-se por duas razões: do uso do substrato como alimento ou como suporte físico para seu crescimento. Obviamente que no primeiro caso a ação é mais prejudicial.

O dano é devido à produção de ácidos orgânicos, oxidação de pigmentos e formação de manchas.

A instalação de biocolonização em uma pedra está condicionada à sua composição mineralógica, porosidade e capacidade de absorção de água do substrato. Quanto maior o valor destes dois últimos parâmetros, como no caso de tufo vulcânico, maior o resultado da degradação.

As características químicas dos minerais também podem selecionar grupos específicos de espécies, especialmente em relação à preferência por condições ácidas, neutras e alcalinas.

Os filmes negros em rochas silicáticas podem ser oriundos de colonização biológica e consistem de películas extremamente finas e aderentes ao substrato com grande dificuldade de remoção.

Como resultado, a biocolonização pode desencadear arenização nos materiais pétreos.

Uma avaliação da presença de organismos nos materiais envolve uma análise qualitativa e quantitativa das espécies presentes. É insuficiente identificar genericamente o grupo taxonômico (por exemplo, alga, líquen...), sendo preferencialmente necessária a colaboração de um biólogo para a sua identificação.

A biodeterioração no patrimônio cultural é extensivamente discutida em Caneva et al. (2009). 


\section{REFERÊNCIAS}

Arnold A., Jeannette D., Zehnder K. 1980. Proposal for a terminology of weathering phenomena on building stone. ICOMOS GP 80

Caneva G., Nugari M.P., Salvadori O. 2009. Plant Biology for Cultural Heritage: Biodeterioration and Conservation. Los Angeles, Getty Publications, 400 p.

Del Lama E.A., Szabó G.A.J., Dehira L.K., Kihara Y. 2008. Impacto do intemperismo no arenito de revestimento do Teatro Municipal de São Paulo. Geologia USP - Série Científica, Revista do Instituto de Geociências USP, 8(1):75-86. Disponível em: http://geologiausp.igc.usp.br/geologiausp/sc1/art.php?artigo=703.

Delgado Rodrigues J. 2015. Defining, mapping and assessing deterioration patterns in stone conservation projets. Journal of Cultural Heritage, 16:267-275.

Dimes F.G. 1990. Sedimentary rocks. In: Ashurst J., Dimes F.G. (eds.) Conservation of building \& decorative stone. Grã-Bretanha, Butterworth Heinemann, Part 1: 61-134.

Fitzner B. \& Heinrichs K. 2002. Damage diagnosis on stone monuments - weathering forms, damage categories and damage indices. In: Prikryl R. \& Viles H. (eds.) Understanding and managing stone decay. International Conference "Stone weathering and atmospheric pollution network (SWAPNET)", Proceedings. Prague, The Karolinum Press/Charles University, p.11-56.

Fitzner B. \& Heinrichs K. 2004. Photo atlas of weathering forms on stone monuments. RWTH Aachen University. Disponível em: http://www.stone.rwth-aachen.de/atlas.htm.

Franke L., Schumann I., Van Hees R., Van der Klugt L., Naldini S., Binda L., Baronio G., Van Balen K., Mateus J. 1998. Damage atlas, classification of damage patterns found in brick masonry - Protection and Conservation of European Cultural Heritage, Research Report European Commission. Stuttgart, Frauenhofer IRB Verlag, 8(2).

Frascá M.H.B.O. 2003. Estudos experimentais de alteração acelerada em rochas graníticas para revestimento. Tese de Doutoramento, Instituto de Geociências, Universidade de São Paulo (IGc-USP), 264 p.

Grimmer A.E. (ed.). 1984. A glossary of historic masonry deterioration problems and preservation treatments. Washington DC, National Park Service Preservation Assistance Division, $67 \mathrm{p}$.

Grossi D. \& Del Lama E.A. 2012. Mapeamento das formas de intemperismo do Monumento a Ramos de Azevedo. Revista CPC (Centro de Preservação Cultural-USP), (14):169-187. Disponível em: http://www.usp.br/cpc/v1/php/wf07_revista_interna.php?id_revista=18\&id_conteudo=25\&tipo=8.

Henriques F.M.A., Delgado Rodrigues J., Aires-Barros L., Proença N. 2005. Materiais pétreos e similares - Terminologia das formas de alteração e degradação. Lisboa, LNEC, 39 p.

ICOMOS - International Council on Monuments and Sites. 1991. Stone Committee Newsletter. Unpublished document. 
ICOMOS - International Council on Monuments and Sites. 2008. Illustrated glossary on stone deterioration patterns. Champigny/Marne, França, ICOMOS, 80 p. Disponível em: http://www.international.icomos.org/publications/monuments_and_sites/15/pdf/Monuments_and_ Sites_15_ISCS_Glossary_Stone.pdf.

Kuzmickas L. 2013. Estado de conservação dos monumentos pétreos do Cemitério da Consolação, São Paulo. Dissertação de Mestrado, Instituto de Geociências, Universidade de São Paulo (IGc-USP), 197 p.

Kuzmickas L. \& Del Lama E.A. 2014. Utilização de métodos não destrutivos no patrimônio histórico: estudo de caso da escultura O Sepultamento de Victor Brecheret. Revista Brasileira de Geologia de Engenharia e Ambiental (RBGEA), 4(1):9-22. Disponível em: http://www.abge.org.br/uploads/arquivos/artigo1-dellama2015100813351380545.pdf.

MDCS - Monument Diagnosis and Conservation System. 2015. The online damage-expert for monumental buildings. Rijksdienst voor het Cultureel Erfgoed. Disponível em: http://mdcs.monumentenkennis.nl/damageatlas.

Ministério da Cultura. 2010. Instrução Normativa n. 1, de 5 de outubro de 2010. Disponível em: $\quad$ http://www2.cultura.gov.br/site/wp-content/uploads/2011/07/IN-n\%C2\%BA-1-2010CONSOLIDADA1.pdf.

Normal 1/88. 1990. Alterazioni macroscopiche dei material lapidei: lessico. Macroscopic alteration of stone materials glossary. Roma, Comas Graphica, 36p.

Queen's University Belfast. S.d. Stone decay in central Oxford. In: The Limestone Project: Understanding the catastrophic decay of building limestone. 10p. Disponível em: http://www.qub.ac.uk/geomaterials/epsrc/resources/weathering_forms.pdf.

Reys A.C., Del Lama E.A., Dehira L.K. 2008. Monumentos da cidade de São Paulo: formas de alteração e conservação. Revista CPC (Centro de Preservação Cultural-USP), (5): 93-122. Disponível

em: http://www.usp.br/cpc/v1/php/wf07_revista_interna.php?id_revista=9\&id_conteudo=22\&tipo= 7.

Ricardo A.M. 2015. Uma rocha e um palácio: características e alterabilidade do Gnaisse Facoidal no Paço Imperial do Rio de Janeiro. Dissertação de Mestrado em Ciências, Instituto de Geociências, Universidade Federal do Rio de Janeiro, Rio de Janeiro, 194 p.

Silva M.E.da \& Roeser H.M.P. 2003. Mapeamento de deteriorações em monumentos históricos de pedra-sabão em Ouro Preto. Revista Brasileira de Geociências, 33(4):329-336.

Silva P.A.B.V. 2014. Deterioração nas pedras da arquitetura mortuária do Cemitério Nossa Senhora da Soledade. Dissertação de Mestrado, Faculdade de Arquitetura e Urbanismo, Universidade Federal do Pará, 211 p.

Silva V.da S. 2007. Alteração de rochas e a conservação do patrimônio arquitetônico: estudo de caso do pórtico da Igreja do Outeiro da Glória. Dissertação de Mestrado, Instituto de Geociências, Universidade Federal do Rio de Janeiro, Rio de Janeiro, 160 p. 


\section{Métodos analíticos}

A conservação do patrimônio construído centra-se em torno de dois grandes desafios. $O$ primeiro é identificar, caracterizar e explicar os problemas que afetam as construções ou os seus componentes, e o segundo é encontrar, validar e especificar as soluções que melhor resolvam ou mitiguem aqueles problemas. Um dos aspectos que integram esses desafios é a seleção e prescrição do tipo de tratamento a ser aplicado nos casos que dele necessitem. Para tanto, é necessário recorrer a um conjunto de estudos que visam desde a compreensão aprofundada do material pétreo em questão, aos processos de deterioração que conduziram ao estado de alteração, à aplicabilidade de um determinado tratamento, à avaliação do conjunto pedra-produto de tratamento, à avaliação dos impactos positivos e negativos do tratamento até à previsão da potencial estabilidade no tempo dos elementos tratados. Naturalmente, o material a ser tratado deve ser devidamente diagnosticado e caracterizado, tanto com relação aos seus atributos químico-mineralógicos quanto ao seu espaço poroso e propriedades físicas (mecânicas e hidráulicas).

O primeiro passo é a inspeção visual e as investigações in situ, com o reconhecimento e mapeamento das formas de alteração.

Após esta fase, procede-se com a amostragem, que deve ser feita com parcimônia e focada na resolução de problemas, evitando subtração desnecessária de material e equacionando a representatividade da amostra.

Para a caracterização dos materiais geológicos, a depender da quantidade de amostras disponíveis, são utilizadas as técnicas analíticas tradicionais, como estudo petrográfico, identificação via microscopia eletrônica de varredura, difração e fluorescência de raios $X$, microssonda eletrônica, espectrometria de massa, porosimetria de intrusão de mercúrio, análises termodiferenciais, entre outras.

A escolha dos métodos a serem utilizados depende do problema a ser solucionado, elencando as questões e definindo a estratégia para respondê-las.

Além das técnicas tradicionais de análise e que estão disponíveis no IGc-USP, existem os métodos não destrutivos para caracterização dos materiais pétreos. A importância dos métodos não destrutivos está na capacidade de se realizar análises de parâmetros diretamente nos bens culturais sem subtração de amostras, preservando sua integridade e produzindo grande volume de dados obtidos in situ, sendo desta forma mais viáveis e adequados para os estudos em patrimônio cultural. 
O Laboratório de Métodos Não Destrutivos - Herança Cultural no IGc-USP está equipado com instrumentos para realizar tais ensaios: espectrofotometria para determinação de cor, determinação da velocidade de propagação de ondas ultrassônicas para avaliar a sanidade interna da pedra, esclerometria para se correlacionar resistência e também sanidade da pedra, e a absorção de água com o método do cachimbo para avaliação da permeabilidade da pedra, além da preparação de microamostras.

Outras instituições possuem laboratórios com enfoque na preservação de monumentos e patrimônio históricos, tais como o LACORE (Laboratório de Conservação, Restauração e Reabilitação) da FAU-UFPA, o LEMETRO (Laboratório de Experimentos em Mecânica e Tecnologia de Rochas) do IG-UFRJ, LABTECRochas (Laboratório de Caracterização Tecnológica de Rochas Ornamentais e de Revestimento) do IGC-UFMG, o LNEC (Laboratório Nacional de Engenharia Civil) de Portugal e recentemente o projeto RIHS (Research Infrastructure for Heritage Science) sediado na Itália, com os quais o nosso laboratório mantém colaboração e trabalho conjunto.

Os métodos analíticos tradicionais já são de conhecimento e domínio mais geral nos estudos geológicos e amplamente descritos, de forma que serão aqui abordados os ensaios não destrutivos voltados para o estudo do patrimônio, existentes no nosso laboratório. Enfatiza-se que não se trata de métodos mais ou menos importantes, apenas equipamentos que estão à disposição no laboratório e dos quais fazemos uso.

\subsection{Colorimetria}

Antes de se definir o significado de cor é necessário que seja apresentada a definição de luz, que é a radiação eletromagnética situada na região do espectro visível.

A faixa de comprimento de onda do espectro visível varia de 380 a $740 \mathrm{~nm}$, sendo assim distribuída: violeta 380-440 nm, índigo 440-460 nm, azul 460-490 nm, verde 490-565 nm, amarelo 565-590 nm, laranja 590-630 nm e vermelho 630-780 nm. Cores com maiores comprimentos de onda têm menores frequências e menores energias.

Segundo Isaac Newton, não há luz colorida, mas sim há uma sequência de cores do espectro da luz visível e que é visualizada de uma maneira única, assim como existem combinações dessas cores, também visualizada de maneira única (Nassau 2001).

Um dos pioneiros da ciência da cor, Dean B. Judd, definiu cor como:

Cor é o aspecto da aparência de objetos e luzes que depende da composição espectral da energia radiante que atinge a retina do olho, considerando sua distribuição temporal e espacial.

Aspectos teóricos sobre cor podem ser encontrados em Murray (1952), Burgess \& Jones (1995) e Nassau (1998 e 2001).

Basicamente, cor é o resultado do tipo de iluminação, das características do objeto iluminado e da percepção do observador, de forma que engloba muita subjetividade na sua determinação. Atualmente, a colorimetria nos permite que a cor seja expressa em números, 
fazendo com que a comunicação sobre a cor seja precisa e objetiva, justamente eliminando a subjetividade na sua determinação.

O termo colorimetria foi originalmente empregado pelos químicos por volta de 1860 quando se referiam à coloração dos líquidos para determinar a concentração das substâncias químicas que elas continham (Johnston 1996).

A cor já foi tratada por filósofos da Antiguidade, como Aristóteles, autor da mais antiga teoria da cor, e Plínio. No século XV, Leonardo da Vinci se contrapôs a Aristóteles e afirmou que a cor era uma propriedade da luz, e não dos objetos. Newton em 1666 estudou a luz branca e as relações com as cores complementares. No século XIX, Göethe publica A teoria das cores, que não teve receptividade pela comunidade científica.

Alguns parâmetros afetam a aparência da cor, tais como: diferenças na fonte de luz, diferenças no observador (as pessoas sofrem desvios na direção do vermelho e do azul, a precisão visual muda com a idade), diferenças de fundo (efeito de contraste), diferenças direcionais (lembrar, p. ex., que é preciso se mudar o ângulo de visão para enxergar a geminação carlsbad no feldspato) e diferenças no tamanho (efeito de área).

Já houve várias tentativas para quantificar a cor numericamente. Por exemplo, A.H. Munsell, em 1905, fez a classificação da cor de acordo com a sua tonalidade (Munsell Hue), luminosidade (Munsell Value) e saturação (Munsell Chroma). Posteriormente, esse sistema foi aperfeiçoado e criado o Sistema de Notação Munsell, utilizado até hoje.

Outros métodos de classificação de cor foram desenvolvidos pela Commission Internacionale d'Eclairage (CIE), uma organização internacional dedicada ao estudo da luz e da cor. Os mais conhecidos são os espaços de cores Yxy (baseado nos valores tristímulos XYZ em 1931) e $L^{*} a^{*} b^{*}$ (desenvolvido em 1976 e proporcionando maior uniformidade nas diferenças de cores em relação às avaliações visuais).

Considerando os métodos acima, a classificação das cores é expressa em tonalidade (cor: vermelho, amarelo, etc.), luminosidade (clara/escura) e saturação (pureza: cores vivas, cores sujas)., sendo que a saturação é totalmente independente da tonalidade e da luminosidade.

Atualmente, o espaço de cor mais utilizado em todos os campos de aplicação é o CIE L*a*b*, em que a cor é descrita por 3 características: claridade (N-S), cor (E-W) e saturação (pureza da cor), onde: $L^{*}$ representa luminosidade e varia de 0 (preto) a 100 (branco); $a^{*}$ e b* são as coordenadas cromáticas: $a^{*}$ positivo é vermelho e $a^{*}$ negativo é verde, $b^{*}$ positivo é amarelo e b* negativo é azul.

As fontes de luz ou iluminantes mais utilizados nesta classificação são: D65 (que simula a luz do dia), A (luz incandescente) e F2 (luz fluorescente).

Imagens fotográficas adquiridas ao longo do tempo podem ajudar o monitoramento dos monumentos em seus diversos aspectos, porém, com relação à cor, as condições ambientais de iluminação e os próprios equipamentos de aquisição das imagens geralmente não são os mesmos, fazendo com que a comparação de imagens de épocas diferentes seja ineficaz no quesito cor.

A medição de cor pode ser feita com os equipamentos: colorímetro ou espectrofotômetro. 
O colorímetro possui 3 filtros receptores simulando os tristímulos $X Y Z$, similar ao processo de aquisição de cor pelo olho humano, porém com a vantagem do colorímetro sempre fazer suas medições utilizando a mesma fonte de luz e o mesmo método de iluminação, seja de dia, de noite, no interior ou exterior de ambientes, tornando as medições extremamente simples e precisas. Os valores tristímulos baseiam-se nos 3 componentes teóricos da visão de cores, que estabelecem que o olho possui 3 cones (receptores, sensores de cores) primários de cores (vermelho, verde e azul), sendo que as outras cores são produtos das misturas dessas 3 cores.

O espectrofotômetro, além de efetuar as mesmas medições que o colorímetro, também mede a reflectância do objeto na região do espectro visível, ou seja, mede a luz refletida do objeto em cada comprimento de onda.

Desta forma, o espectrofotômetro apresenta a vantagem de utilização, em relação ao colorímetro, de fornecer o gráfico da reflectância espectral da cor além dos demais valores numéricos, bastante útil na interpretação do quesito cor na avaliação do grau de alteração de determinado monumento.

Existem dois métodos de medição de cor, segundo a classificação CIE L*a*b*: um método que inclui a reflectância especular e outro que não inclui a reflectância especular.

O método que inclui a reflectância especular é chamado de SCI (Specular component Included - Componente especular incluso). A medição é feita sem uma armadilha de luz, a que propicia a inclusão da luz especular. Este método é preponderantemente utilizado nas áreas de pesquisa e desenvolvimento de cores.

O outro método, que exclui a reflectância especular, é chamado de SCE (Specular Component Excluded - Componente especular excluso). Esse método utiliza uma armadilha de luz para que a reflectância especular não seja medida, e que é ideal para a utilização em comparação de cores em salas de inspeção ou em linhas de produção industrial.

A luz especular refletida é definida como sendo aquela que, quando atinge um objeto, reflete no mesmo ângulo e em direção oposta.

A reflectância especular mais a reflectância difusa é a reflectância total.

O componente especular é fraco em superfícies rugosas, mas forte no difuso. Situação contrária ocorre em superfícies polidas.

Na medição de cor, como as pessoas veem, deve-se considerar apenas a reflectância difusa.

Apesar da variação das reflectâncias difusa e especular, a depender da superfície, a quantidade total de luz refletida é sempre a mesma.

Bobin et al. (2003) discutem a correspondência entre a cor difusa e as concentrações de cobre e prata em azulejos na Tunísia mas alertam que a correlação tem validade apenas para as amostras estudadas. Demonstraram que a cor verde tem mais $\mathrm{Ag}$ que $\mathrm{Cu}$ e as cores marrom e ocre-amarela têm mais Cu que Ag.

Um dos grandes problemas durante um projeto de conservação é a alteração das cores originais do objeto em questão, devido à reação com os produtos utilizados na restauração (argamassas, consolidantes, biocidas, hidrofugantes, etc.) e a sintonia cromática (ou a falta 
dela) entre os materiais originais e os que foram acrescentados, prejudicando a leitura estética desse objeto.

Mudanças de cor nas pedras de edifícios são produzidas por uma grande variedade de condições ambientais, tais como, intemperismo, poluição urbana, crescimento de organismos biológicos, excrementos de pássaros, fogueiras, eflorescência, defeitos na construção, tratamentos de conservação (limpeza, consolidantes), entre outros.

A estabilidade da cor da pedra é um parâmetro que deve ser entendido e monitorado devido à deterioração estética produzida pelas condições ambientais e poluição urbana.

A quantificação desta descoloração é importante tanto para a indústria das rochas ornamentais como para a conservação arquitetônica.

Mudanças de cor em rochas são normalmente atribuídas ao grau de oxidação do cromóforo. Um dos cromóforos mais potentes é o ferro.

Fases minerais com material férrico oxidado produz cor vermelha a marrom na rocha, enquanto que fases reduzidas produzem cor azul a preta. Quando estas rochas são expostas à atmosfera, ocorrerão reações de oxidação. Por esta razão, fases reduzidas mudam de cor rapidamente, enquanto fases oxidadas geralmente permanecem estáveis ao intemperismo.

Medidas experimentais em rochas mostram que há mudanças significativas em $L^{*}$ e b* após um período de exposição externa. A mudança de cor em $b^{*}$ indica um processo de amarelamento (yellowing) e pode ser mais rápido que o escurecimento (blackening). 0 amarelamento pode surgir de processos diferentes incluindo sulfatação (Grossi et al. 2007a) ou a deposição ou oxidação de material orgânico ou ferro (Simon \& Snethlage 1996, apud Grossi \& Brimblecomble 2007). Eventualmente num futuro próximo, em uma atmosfera mais dominada pelos poluentes orgânicos, é possível que o processo de amarelamento possa ser mais importante, dependendo dos tipos de material afetados.

Bellan et al. (2000, apud Grossi \& Brimblecomble 2007) apontam que observadores somente são capazes de detectar que uma amostra está se tornando suja, quando a superfície coberta por partículas pretas de carbono alcança 2,4\%.

Os estudos de caso em análise de cor em monumentos e edifícios históricos foram feitos por diversos pesquisadores, sendo citados alguns desses estudos a seguir.

Costa \& Delgado Rodrigues (1996) discutem uma metodologia para avaliar mudanças cromáticas resultantes de tratamento de rochas.

Ferreira Pinto et al. (1996a e b) avaliaram mudanças cromáticas induzidas pela aplicação de quatro repelentes de água em rochas graníticas e por ensaios de intemperismo acelerado, sendo que no primeiro caso não houve mudanças significativas nas superfícies tratadas, indicando que com relação à cor, os produtos utilizados não foram nocivos.

Iñigo et al. (1997) estudaram as mudanças de cor de cinco granitos devido à aplicação de consolidantes e repelentes de água na cidade de Ávila.

García-Talegon et al. (1998) analisaram as mudanças cromáticas após tratamento de consolidação e impermeabilização no arenito dourado em Salamanca. 
Para determinar o grau de sujidade de edifícios urbanos sujeitos à poluição ambiental, Fort et al. (2000) definiram os parâmetros cromáticos antes e depois da limpeza, mostrando grandes variações para o parâmetro $L^{*}$. Os parâmetros $a^{*} e b^{*}$ não se alteraram muito. $O$ uso desses parâmetros para avaliar objetivamente a efetividade do tratamento de limpeza e seu controle de qualidade é uma abordagem pertinente. Variações em $L^{*}$ também foram observadas por Franceschi et al. (2006) em pátinas e tratamentos em monumentos de bronze.

Feliu et al. (2005) estudaram a cor das fachadas de um edifício histórico em Cadiz objetivando conhecer a história dessa construção e escolher materiais e cores que possam ser usados em intervenções futuras.

Rodríguez-Gordillo et al. (2007) estudaram o comportamento cromático de pigmentos inorgânicos em quatro tipos de argamassa.

Grossi et al. (2007a) investigaram o impacto do intemperismo e de processos de conservação em calcários espanhóis, tais como, ataque de $\mathrm{SO}_{2}$, escurecimento da pedra em ambientes urbanos e limpeza a laser, provocando alteração nos parâmetros cromáticos $b^{*}, L^{*}, e$ a* e b*, respectivamente.

Grossi et al. (2007b) trataram especificamente de limpeza a laser em granitos, apontando a alteração do parâmetro cromático $\mathrm{a}^{*}$, interpretada como resultante da variação de compostos de $\mathrm{Fe}$, no caso a presença de biotita e o teor de $\mathrm{Fe}_{2} \mathrm{O}_{3}$ nos feldspatos potássicos, que condiciona fortemente a cor da rocha.

Souza et al. (2008) apresentaram análise colorimétrica de seis rochas ornamentais brasileiras: Granito Ouro Mel, Granito Cinza Corumbá, Granito Marrom Imperial, Granito Café Bahia, Granito Branco São Paulo e Granito Arabesco, apontando que a técnica de medição de cor pode ser aplicada no controle de qualidade na construção civil com a escolha do material.

O brilho e o polimento influenciam na cor, consequentemente variações da rugosidade superficial também alteram a cor. Objetos escuros são particularmente afetados pela mudança de brilho enquanto que os claros não. Isto pode ser atribuído ao componente especular da luz que é seletivamente refletido. Esse componente contribui menos que o componente difuso para diluir a luz refletida colorida do objeto. De qualquer forma, não há mudança na tonalidade, já que a estrutura de banda dos compostos cromóforos da rocha permanece constante, sem qualquer mudança nas transições permitidas e proibidas da luz visível (Benavente et al. 2003).

Um dos mecanismos de deterioração estética mais importantes que as rochas podem ser submetidas é um aumento na rugosidade superficial pela ação do intemperismo. A influência da rugosidade superficial na determinação da cor não é um problema exclusivo das rochas, sendo que em pinturas esse aumento de rugosidade também pode prejudicar essa determinação (Berns et al. 2006).

Prieto et al. (2010) apontam que apesar da cor ser um parâmetro físico-químico mais comumente usado para caracterizar rochas ornamentais, não há ainda um protocolo padrão para medí-la. Os autores propõem assim um número de medidas mínimas, de acordo com a área considerada, para caracterizar a cor de rochas graníticas. Para espectrofotômetro com abertura de $8 \mathrm{~mm}$, por exemplo, que é o caso do Konica Minolta 2500d existente no 
Laboratório de Métodos Não Destrutivos - Herança Cultural no IGc-USP, foi adotada a quantidade de14 medidas $/ 36 \mathrm{~cm}^{2}$.

Este equipamento foi usado para caracterizar a cor de alguns monumentos na cidade de São Paulo, assim como pinturas do artista Alfredo Volpi, conforme ilustrado na Figura $5.1 \mathrm{e}$ parágrafos seguintes.
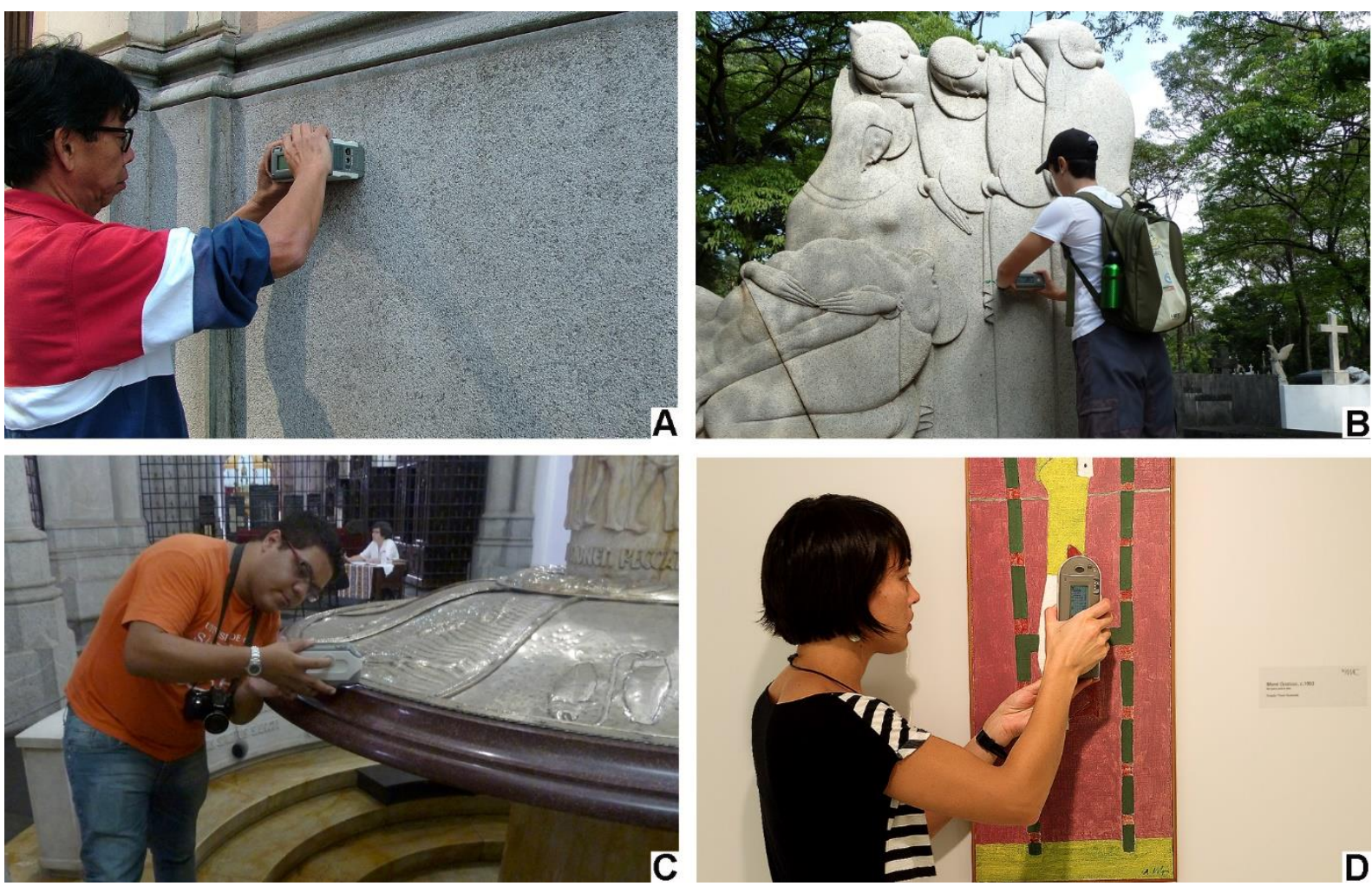

Figura 5.1. Medição de cor com espectrofotômetro em monumentos da cidade de São Paulo. A. Granito Itaquera, Igreja Santo Antônio. B. Granito Itaquera, Cemitério da Consolação. C. Pórfiro Imperial, Sé. D. Pintura de Alfredo Volpi. Fotografia D: Pedro H.O.V. Campos.

Mori (2015) e Mori et al. (2016) documentaram as cores de pinturas de Volpi com o uso de espectrofotômetro, entre outras informações, que podem iniciar a criação de um banco de dados sobre a obra deste artista.

Kuzmickas (2013) e Machado (2015) coletaram os parâmetros cromáticos de pedras constituintes de jazigos do Cemitério da Consolação e da Sé de São Paulo, respectivamente.

A caracterização cromática do Granito Itaquera foi realizada por Grossi (2013), Kuzmickas \& Del Lama (2014), Grossi et al. (2015) e Del Lama et al. (2016).

Esses estudos efetuados com o uso do espectrofotômetro do Laboratório do IGc-USP compõem um banco de dados colorimétricos que poderá ser usado para futuras comparações para análise e determinação do estado de alteração dos monumentos, utilizando como parâmetro a cor das pedras que os compõem. 
No final do século XIX e início do XX, provavelmente os monumentos da cidade de São Paulo apresentavam luminosidade alta e nuances de tonalidade verde e azul. Atualmente, os monumentos adquiriram tonalidades mais acinzentadas e amareladas, como constatado pelos dados colorimétricos medidos, provavelmente devido à deposição de poluentes atmosféricos e intemperismo de minerais ricos em ferro (Del Lama et al. 2016).

\subsection{Velocidade de propagação de ondas ultrassônicas}

O método de medida das ondas ultrassônicas permite a avaliação da qualidade da pedra, assim como a verificação da existência e identificação de fraturas profundas e superficiais.

O uso de ondas ultrassônicas para ensaios não destrutivos iniciou-se por volta de 1920 e foi originalmente desenvolvido para ser usado em concreto.

Para análises em concreto, as normas para os ensaios são: ABNT NBR 8802/94 (ABNT 1994), BS EN 12504-4 (BS 2004) e ASTM C-597/2016 (ASTM 2016). Em rochas, a determinação da velocidade ultrassônica baseia-se na norma técnica ASTM D 2845/08 (ASTM 2008) da American Society for Testing and Materials.

O método ultrassônico é adequado tanto para análises no campo ou em amostras no laboratório, por ser totalmente portátil e de fácil operação. O aparelho gera pulsos ultrassônicos de baixa frequência e mede o tempo que eles levam para atravessar o material, de um transdutor para o outro, apontando condições não homogêneas quando presentes na pedra.

Sinais de boa qualidade, correlacionados a altas velocidades de propagação do som, indicam uma rocha não alterada, enquanto sinais moderados e de baixa qualidade, a que correspondem baixas velocidades de propagação, indicam rocha intemperizada e/ou presença de fraturas em seu interior.

Quanto maior a frequência do transdutor, menor o feixe de propagação de ondas. A frequência usada para testar concreto e rocha é muito menor do que a usada em metais. As frequências adequadas para aqueles materiais variam de 20 a $250 \mathrm{kHz}$, sendo a mais usada a de $50 \mathrm{kHz}$.

Em um material sólido, a velocidade ultrassônica depende das propriedades elásticas e densidade deste material. A análise é feita medindo exatamente o tempo de percurso do pulso ultrassônico através do material que está sendo testado. A distância que a onda percorre no material para que se possa determinar a velocidade pela relação: velocidade $=$ distância/tempo, é a distância entre os transdutores que são instalados no objeto em estudo.

Normalmente, a aplicação de 3 pulsos a cada 4 segundos é adequada para testar concreto e rocha. Para cerâmica e materiais mais finamente granulados, emissão de pulso único é suficiente e adequado Para materiais porosos, é mais conveniente a aplicação de grande número de pulsos por leitura. Frequências mais altas são úteis para materiais muito densos.

As aplicações são inúmeras, tais como: indicação da homogeneidade/heterogeneidade do material, presença de vazios, fissuras ou outras imperfeições, estimativa da resistência, determinação do módulo de Young e o coeficiente de Poisson, e determinação da profundidade da fissura. 
Para a execução do ensaio, existem 3 possibilidades de geometria na colocação dos transdutores para obtenção das medidas de velocidade de propagação (Figura 5.2), as quais são descritas a seguir.

Transmissão direta - os transdutores são colocados em faces opostas do material. A transmissão direta requer que o objeto seja acessível pelos lados opostos, fato que pode trazer algumas limitações para a aplicabilidade do método, dependendo do objeto a ser investigado. Este é o método mais sensível, com o transdutor-receptor recebendo a máxima energia do pulso transmitido, uma vez que os pulsos longitudinais são propagados principalmente na direção normal à face do transdutor.

Transmissão semidireta - os transdutores são colocados em faces adjacentes. Este é o segundo melhor método para obtenção das medidas de propagação das velocidades.

Transmissão indireta ou superficial - os transdutores são colocados na mesma face. Este método deve ser usado somente quando seja impossibilitado o acesso a duas faces do material. Neste método, a amplitude recebida, para o mesmo comprimento, é somente cerca de $2 \%$ do sinal recebido em comparação ao método da transmissão direta. $O$ arranjo indireto é possível porque o feixe ultrassônico de energia é espalhado nas descontinuidades do material testado. O tempo de viagem da onda é afetado somente pelas propriedades do material muito próximo à superfície.

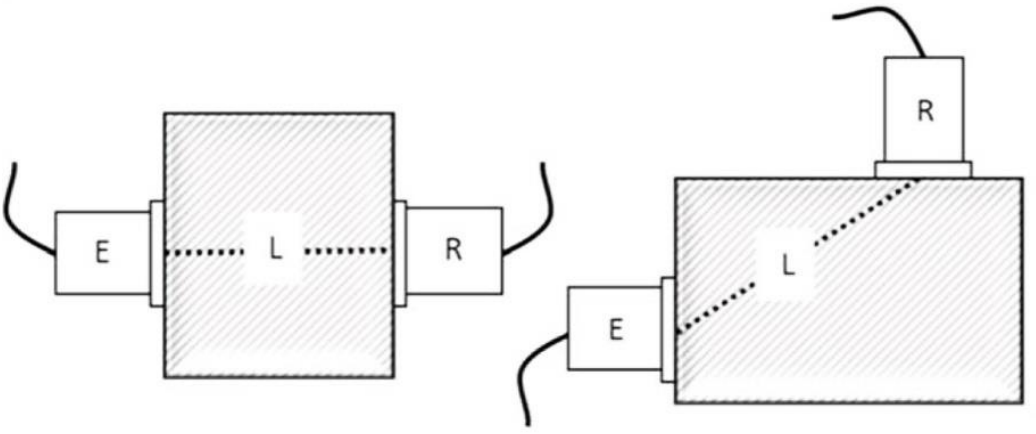

(A)

(B)

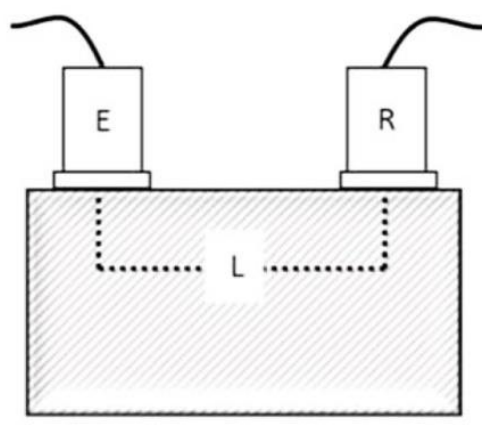

(C)

Figura 5.2. Tipos de transmissão (E: transdutor emissor, R: transdutor receptor, L: distância entre os transdutores). A. Direta. B. Semidireta. C. Indireta. Fonte: Gimenez \& Del Lama (2014, adaptado de ABNT NBR 8802/94).

A execução de rotinas sistemáticas de inspeção nos monumentos pode apontar o estágio do processo de deterioração e a pronta intervenção para retardar ou deter este processo. Dessa maneira, os custos neste tipo de manutenção podem ser reduzidos se a intervenção for efetuada quando o processo for detectado no seu início.

Uma outra aplicação para esta técnica é para a indicação da profundidade de penetração dos consolidantes no tratamento de rocha (Delgado Rodrigues et al. 1996, Scherer \& JiménezGonzaléz 2008, e vários outros exemplos citados a seguir).

Mariani et al. (2008) usaram velocidades ultrassônicas para comparar amostras saturadas e amostras secas de tufo amarelo napolitano.

Delgado Rodrigues \& Costa (2008) compararam a aplicação de 3 consolidantes nos granitos alterados da Catedral de Évora, usando a velocidade ultrassônica para verificar a profundidade de penetração dos produtos. 
Spathis et al. (2008) aplicaram 7 tipos diferentes de consolidantes em tijolos e tijolos argilosos na Tessalônica e concluíram que os tratamentos diminuem a porosidade e a permeabilidade de água mas diminuem também a resistência mecânica dos materiais.

Pamplona et al. (2008) aplicaram os consolidantes TEOS e TEOS-C em calcários alterados de Ançã. Entre os vários métodos utilizados para avaliação da eficácia, foi feita a medida a velocidade ultrassônica. Os resultados apontaram que o produto TEOS-C é mais efetivo para melhorar as propriedades mecânicas da rocha, porém a variação de cor ficou além do limite aceitável $\left(\Delta E^{*} \geq 5\right)$.

Álvarez et al. (2008) usaram 2 etil-silicatos (Tegovakon V100 e Wacker OH 100) no granito da Igreja São João dos Reis em Toledo. A velocidade ultrassônica foi usada para avaliar a eficácia dos dois produtos após ciclos de congelamento e degelo. Após o tratamento, as velocidades ultrassônicas aumentaram, consequência do aumento da coesão das partículas na rocha. A profundidade de penetração dos produtos atingiu de 12 a $25 \mathrm{~cm}$.

Costa \& Delgado Rodrigues (2008) fizeram uma avaliação dos tratamentos com consolidantes, avaliando o tipo de rocha, quais consolidantes deveriam ser testados, como aplicá-los e como medir sua eficácia. Para esses autores, o melhor instrumento para medir a eficácia dos consolidantes em rochas graníticas é o ultrassom, com avaliações feitas no laboratório, complementadas com informações obtidas in situ. Os protocolos são condicionantes decisivos que devem ser levados em consideração quando a informação é transposta para a prática.

Gonçalves (2010) discutiu a velocidade ultrassônica em argamassas comparando os transdutores planos e os exponenciais, apontando a dificuldade para a interpretação dos dados.

Uma utilização um pouco diferente do ultrassom foi realizada por Delgado Rodrigues (1978), que calculou a alterabilidade de dolerito usado em pavimentos das ruas de Lisboa.

O Laboratório de Métodos Não Destrutivos - Herança Cultural do IGc-USP possui um Ultrassom V-Meter III da James Instruments Inc., que foi utilizado para medir as velocidades de propagação de ondas ultrassônicas nos monumentos da cidade de São Paulo (Figura 5.3).

Anteriormente, os equipamentos de ultrassom mediam somente o tempo que a onda percorria no material e, tendo-se a distância, obtinha-se a velocidade. O aparelho do laboratório já fornece o cálculo da velocidade, tornando seu uso mais prático. Na realidade, isso funciona bem para ensaios em laboratório com tamanhos de amostra pré-estabelecidos. No campo, onde os espaçamentos dos ensaios têm medidas variáveis, a distância deve ser fornecida a cada análise.

Após testes iniciais com o uso do equipamento, notou-se que os transdutores planos apresentaram dados satisfatórios, mas para os transdutores exponenciais os dados obtidos não eram compatíveis. Após muitas análises, concluiu-se que o tempo de trânsito apresentado no equipamento não descontava o tempo de percurso no transdutor, apresentando um tempo muito superior ao real.

Para sanar este problema foi usado um osciloscópio, onde foi medido o tempo de percurso da onda no transdutor. A partir disso, ao utilizar os transdutores exponenciais subtrai-se 0 
valor obtido no osciloscópio do tempo medido no aparelho, obtendo-se assim a velocidade real.

Uma proposta metodológica de utilização do ultrassom em monumentos é apresentada por Gimenez \& Del Lama (2014).
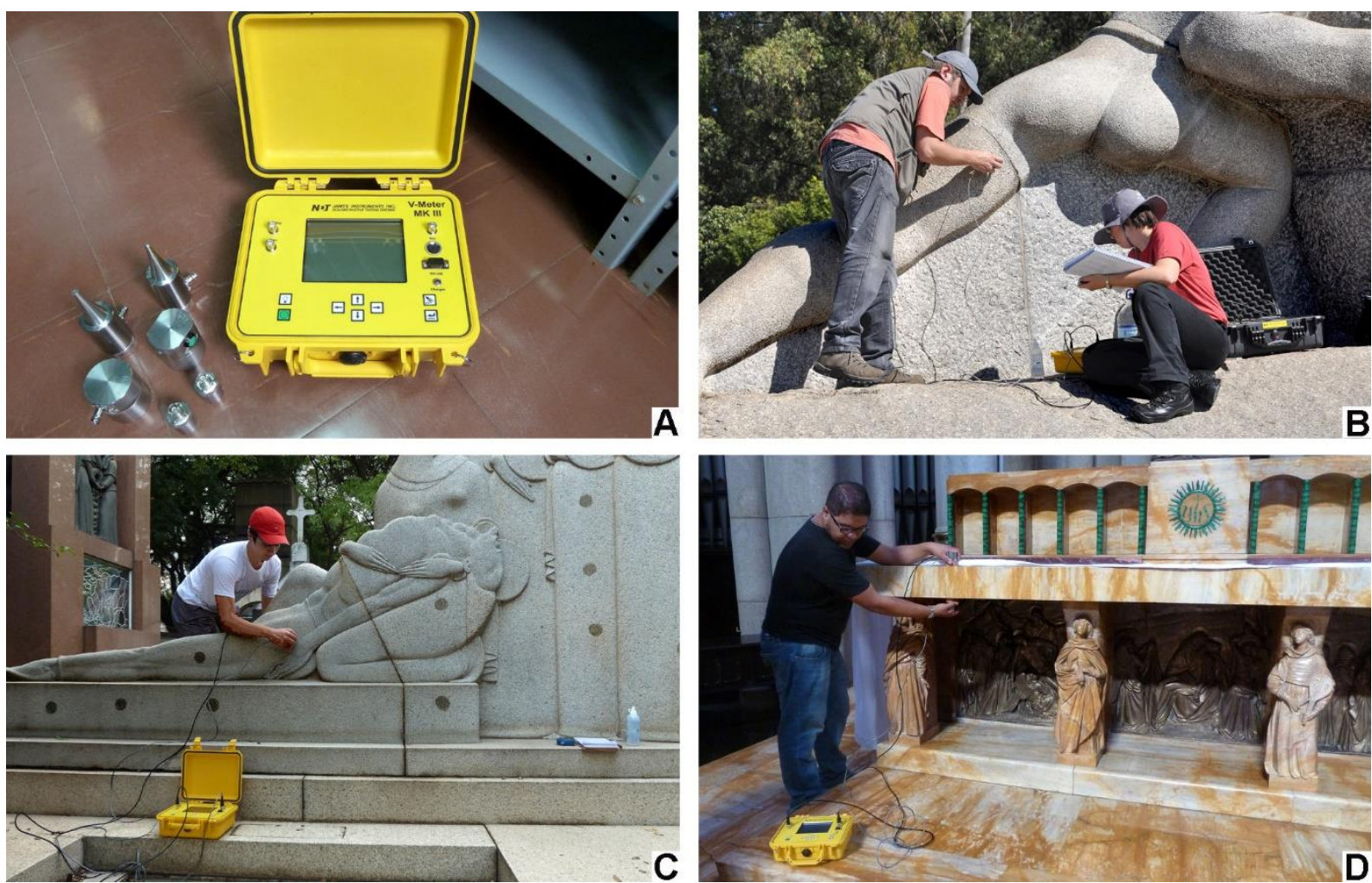

Figura 5.3. Obtenção de velocidade de propagação de ondas ultrassônicas em monumentos da cidade de São Paulo. A. Equipamento V-Meter III, James Instruments Inc., e transdutores planos de 54 e $150 \mathrm{kHz}$ e exponenciais de $54 \mathrm{kHz}$. B. Granito Cinza Mauá, Monumento às Bandeiras. C. Granito Itaquera, escultura O Sepultamento, Cemitério da Consolação. D. Giallo de Siena, Sé. Fotografia B: Lauro K. Dehira.

Ensaios para obtenção da velocidade de ondas ultrassônicas foram realizadas no Monumentos às Bandeiras, no Parque Ibirapuera, São Paulo (Gimenez 2012), na escultura O Sepultamento, no Cemitério da Consolação em São Paulo (Kuzmickas \& Del Lama 2014) e no Monumento em Homenagem a Ramos de Azevedo, na Cidade Universitária em São Paulo (Grossi \& Del Lama 2015). Dentre estes levantamentos, apenas em O Sepultamento foi observada, localmente, diminuição de velocidade nas bordas da escultura. Nos outros dois monumentos estudados o resultado da medição das velocidades das ondas ultrassônicas apresentaram velocidades indicativas de pedra sã.

Machado (2015) aponta que, à exceção do serpentinito, as demais pedras constituintes da Sé de São Paulo apresentam velocidades de propagação de ondas ultrassônicas compatíveis com pedras não alteradas.

\subsection{Esclerometria}

O esclerômetro de Schmidt (Figura 5.4) é um instrumento de uso fácil, para medidas rápidas e aproximadas da resistência do material, correlacionando estes dados com a resistência à 
compressão uniaxial, que é medida em $\mathrm{kgf} / \mathrm{cm}^{2}$ (quilograma-força por centímetro quadrado) ou MPa (megapascal). Este aparelho foi criado no final dos anos 40 pelo engenheiro suíço Ernest Schmidt e por isso também é chamado de Martelo de Schmidt (Schmidt Hammer). Originalmente o equipamento foi idealizado para medição de resistência em concreto.

É um aparelho portátil, podendo ser usado em laboratório ou in situ, e é um método não destrutivo (com os devidos cuidados), podendo ser usado em monumentos históricos como um instrumento auxiliar nos estudos de caracterização, correlacionando a resistência aos golpes do martelo com a sanidade da pedra.
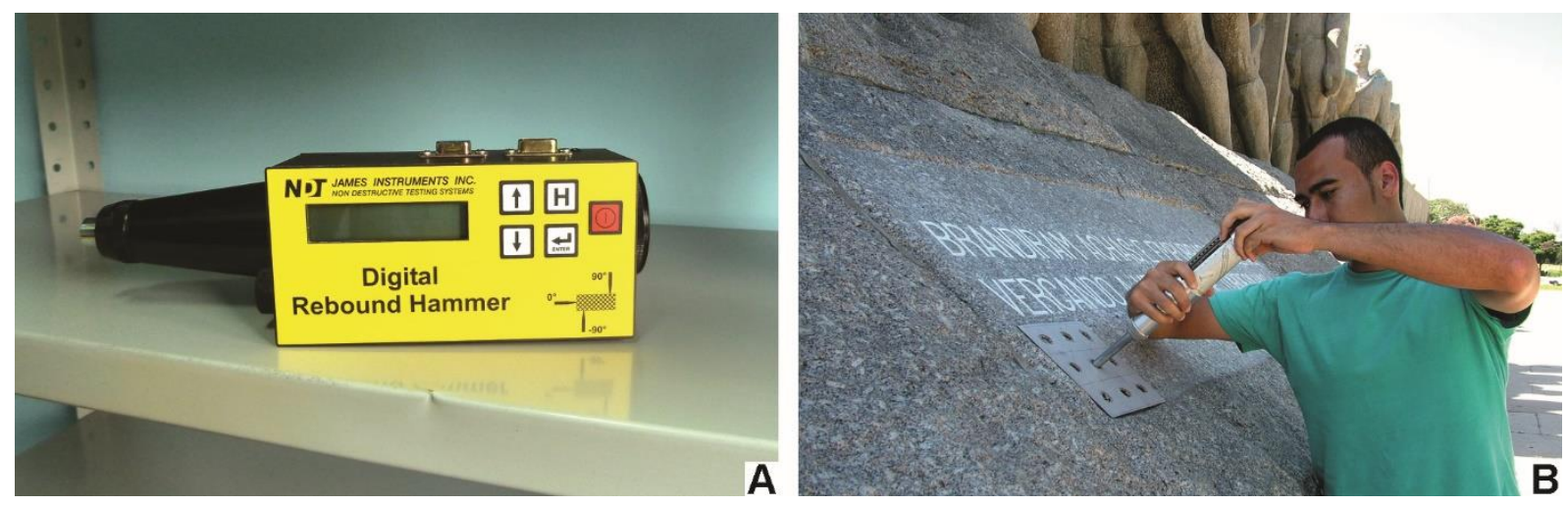

Figura 5.4. A. Esclerômetro WD2000, NDT James Instruments Inc., tipo L. B. Ensaio no Monumento às Bandeiras.

Sua utilização é muito simples: pressiona-se o martelo contra uma superfície lisa e plana, e quando completamente pressionado após a emissão de um golpe, o martelo indica um número conhecido como Schmidt rebound number. A intensidade do rebound/ricochete é proporcional à resistência, pois quanto mais resistente for o material, maior será este número. Correlações dos valores Schmidt são feitas para se obter os valores de resistência uniaxial da rocha, que vai indicar o grau de sanidade e/ou fraturamento da rocha.

Os principais procedimentos para o ensaio esclerométrico podem ser encontrados nas recomendações da ISRM (1978), na norma brasileira ABNT NBR-7584 (ABNT 1995) e na norma da ASTM D 5873-00 (ASTM 2000).

Há uma boa correlação entre os valores obtidos com o esclerômetro e os testes de módulo de Young, resistência à compressão unixial e teste de carga pontual (Aufmuth 1973, Xu et al. 1990, Katz et al. 2000, Buyuksagis \& Goktan 2007, Aydin \& Basu 2005).

O esclerômetro pode ser confeccionado com diferentes níveis de energia de impacto, sendo os tipos $\mathrm{L}$ e $\mathrm{N}$ os mais comuns para testes em rochas e concretos, com os valores de energia de 0,735 e 2,207 Nm, respectivamente (Buyuksagis \& Goktan 2007). Estes autores discutem o efeito destes dois tipos de esclerômetro na resistência à compressão uniaxial de rochas, concluindo que as medidas obtidas com o tipo $\mathrm{N}$ são mais adequadas para esta estimativa, em um intervalo de 20 a $290 \mathrm{MPa}$ (intervalo entre a rocha alterada e a rocha sã).

Aydin \& Basu (2005) já haviam apontado que o esclerômetro do tipo N é mais eficiente na correlação com a resistência à compressão uniaxial e com o módulo de Young. 
Para correlacionar o índice esclerométrico com a resistência à compressão uniaxial, Katz et al. (2000) testaram vários litotipos, entre eles, granito, mármore, arenito, sienito e calcário, e concluíram que a correlação teria maior veracidade se a rocha fosse homogênea ou bem cimentada, sua superfície fosse lisa e polida, sem fraturas, e que não ocorresse desintegração da rocha durante o ensaio com o esclerômetro.

Aydin \& Basu (2005) estudaram a correlação entre os esclerômetros do tipo $L$ e do tipo N com rochas graníticas em diferentes níveis de intemperismo, e concluíram que o esclerômetro do tipo $\mathrm{N}$ apresenta uma dispersão menor de índices esclerométricos (menor variância), pois possui maior energia de impacto e maior diâmetro do êmbolo de impacto, porém o esclerômetro do tipo $L$ é mais sensível para detectar microfraturas ou descontinuidades por ter menor energia de impacto e menor diâmetro do êmbolo de impacto.

De acordo com Aydin (2009), tanto o esclerômetro do tipo $N$ quanto o do tipo $L$ devem ser utilizados com cautela quando o valor da resistência uniaxial da rocha está abaixo de $20 \mathrm{MPa}$ ou acima de $120 \mathrm{MPa}$, porque a sensibilidade do aparelho diminui e a variância do índice esclerométrico aumenta.

Nos trabalhos de conservação nota-se que este aparelho, porém, não é muito usado em pedras de cantaria, sendo que poderia ter uma utilização maior, devido ao seu caráter não destrutivo e de rapidez na avaliação da deterioração. Suas vantagens além da rapidez, incluem portabilidade, baixo custo, obtenção das medidas in situ e simplicidade.

Teixeira et al. (2008) demonstraram a utilização do Martelo de Schmidt na caracterização do estudo de deterioração das rochas do pórtico da Igreja de Nossa Senhora da Glória do Outeiro no Rio de Janeiro.

Sánchez et al. (2008) trataram da deterioração do Leucogranito San Pedro, usado em muitos edifícios históricos da cidade de La Coruña (NW da Espanha). O tratamento neste granito deteriorado foi a aplicação de consolidante e, para a efetividade do tratamento, foi necessária a investigação em relação à sua porosidade. Existem estudos que mostram a relação entre a porosidade e o valor do índice esclerométrico. O trabalho permitiu estabelecer uma relação entre o intemperismo e o valor do índice esclerométrico, provendo um método rápido para avaliação dos métodos de conservação in situ dos granitos deteriorados.

Augusto (2009) realizou ensaios de esclerometria em monumentos da cidade de São Paulo, correlacionando-os com a resistência à compressão uniaxial, obtendo-se resultados satisfatórios na avaliação do grau de alteração dos materiais pétreos.

Alguns pontos são importantes na aplicação deste ensaio em monumentos, e que devem ser considerados antes do uso de esclerômetros:

- Escassez de superfícies lisas e limpas nos monumentos, pois superfícies rugosas e sujas mascaram os valores dos índices esclerométricos, tornando-os mais baixos, gerando assim a avaliação de que as rochas têm resistências à compressão menores (valores não reais);

- Monumentos constituídos por pedras com superfícies muito alteradas poderiam sofrer marcas com pequenas impressões deixadas pelo esclerômetro devido ao impacto, tornando seu uso inadequado; 
- Impossibilidade de demarcação de malhas regulares para a obtenção da média de índices esclerométricos em alguns monumentos, devido ao arredondamento ou ao tipo de acabamento na superfície das estátuas;

- Devido à maior energia de impacto, o esclerômetro tipo $\mathrm{N}$ não deve ser utilizado em monumentos, pois pode ocasionar danos na sua superfície. Alguns autores apontam que os valores obtidos com o tipo $\mathrm{N}$ correlacionam melhor com os dados de resistência à compressão uniaxial, mas reitera-se aqui que este tipo de esclerômetro não é adequado ao tema em estudo. Portanto, considera-se que o esclerômetro tipo $L$ é mais adequado para esta finalidade, mas mesmo assim deve ser usado com muita cautela nas superfícies lisas dos monumentos.

\subsection{Teste de absorção de água}

A absorção de água pelos materiais está intrinsecamente ligada ao fenômeno da capilaridade, que influencia o mecanismo de evaporação da água, drenando a água de dentro do material para a superfície. A capilaridade também controla o movimento de água e sais solúveis de um material para outro.

Schaffer (1932, e demais re-edições, a última em 2004) discutiu esta propriedade particularmente em pedras: quando materiais diferentes são colocados em contato, a água drenará dos poros maiores para os menores, uma vez que a sucção de capilaridade é maior em poros menores. Os materiais de construção contêm poros dos mais variados tamanhos, e por isso a força de sucção variará conforme a umidade presente. O grau de saturação também deve ser considerado nesta análise, pois ela pode alterar a direção do movimento da água entre dois materiais.

Entre dois materiais de características diferentes, a condição de equilíbrio estático é atingida quando as sucções de capilaridades são iguais. Porém, em edifícios, a umidade dos materiais está sempre variando, o que torna o problema mais dinâmico que estático.

Portanto, como a sucção de capilaridade de um material varia com a umidade, e a taxa de mudança de umidade sob condições secas ou úmidas varia com diferentes materiais, a predição da direção de transferência de água entre quaisquer dois materiais é extremamente complexa.

Materiais de construção são porosos, e são mais ou menos permeáveis à água. A estrutura desses materiais apresenta um sistema de poros finos interconectados. Umedecimento por água líquida envolve condução (sucção) de capilaridade através deste sistema de poros, ao longo de caminhos verticais e horizontais. Transporte vertical vai ocorrer quando a água entra como água subterrânea na base de uma estrutura ou como água de chuva direto de calhas. Penetração da chuva em superfícies de paredes resulta em transporte horizontal. Em termos práticos, a quantidade de chuva que penetra depende das condições do vento e da composição e condição da superfície exposta.

O umedecimento de um material de construção dependerá de sua estrutura capilar e a distribuição do tamanho dos poros. 
O instrumento para se medir a absorção de água em baixa pressão é simples. A Figura 5.5 ilustra o aparato como um cachimbo para superfícies verticais. Sua borda circular e plana é afixada na superfície de alvenaria com argila (ou outro material impermeável). A abertura, base do cachimbo, tem uma área de $4,9 \mathrm{~cm}^{2}$. O tubo vertical é graduado de 0 a $5 \mathrm{~mL}$ com cada graduação representando um incremento de $0,5 \mathrm{~mL}$. A altura total da coluna de água aplicada na superfície, medida do ponto central da borda para o ponto mais alto, é de $12 \mathrm{~cm}$. Isto corresponde a uma pressão de 1.177,2 Pascal, ou uma pressão de vento dinâmica de $157,8 \mathrm{~km} / \mathrm{h}$. O cachimbo para superfície vertical do Laboratório de Métodos Não Destrutivos - Herança Cultural do IGc-USP é graduado até $4 \mathrm{~mL}$ e a altura da coluna de água é de $9 \mathrm{~cm}$ (mesmo se fosse graduada até $5 \mathrm{~mL}$, a altura seria de $10,5 \mathrm{~cm}$ ).

O aparato designado para aplicação em superfícies horizontais, similar ao de superfície vertical, é também ilustrado na Figura 5.5. O tubo horizontal é graduado da mesma maneira que o tubo vertical. A altura total da coluna de água aplicada na superfície, medida do ponto central da borda para o ponto mais alto é $13,4 \mathrm{~cm}$. Isto corresponde a uma pressão de $1.314,5$ Pascal, ou uma pressão de vento dinâmica de $166,8 \mathrm{~km} / \mathrm{h}$. O cachimbo para superfície horizontal do Laboratório de Métodos Não Destrutivos - Herança Cultural do IGc-USP é graduado até $3,5 \mathrm{~mL}$ e a altura da coluna de água é de $13 \mathrm{~cm}$ (se fosse graduada até $5 \mathrm{~mL}$, a altura seria de $16 \mathrm{~cm}$ ).
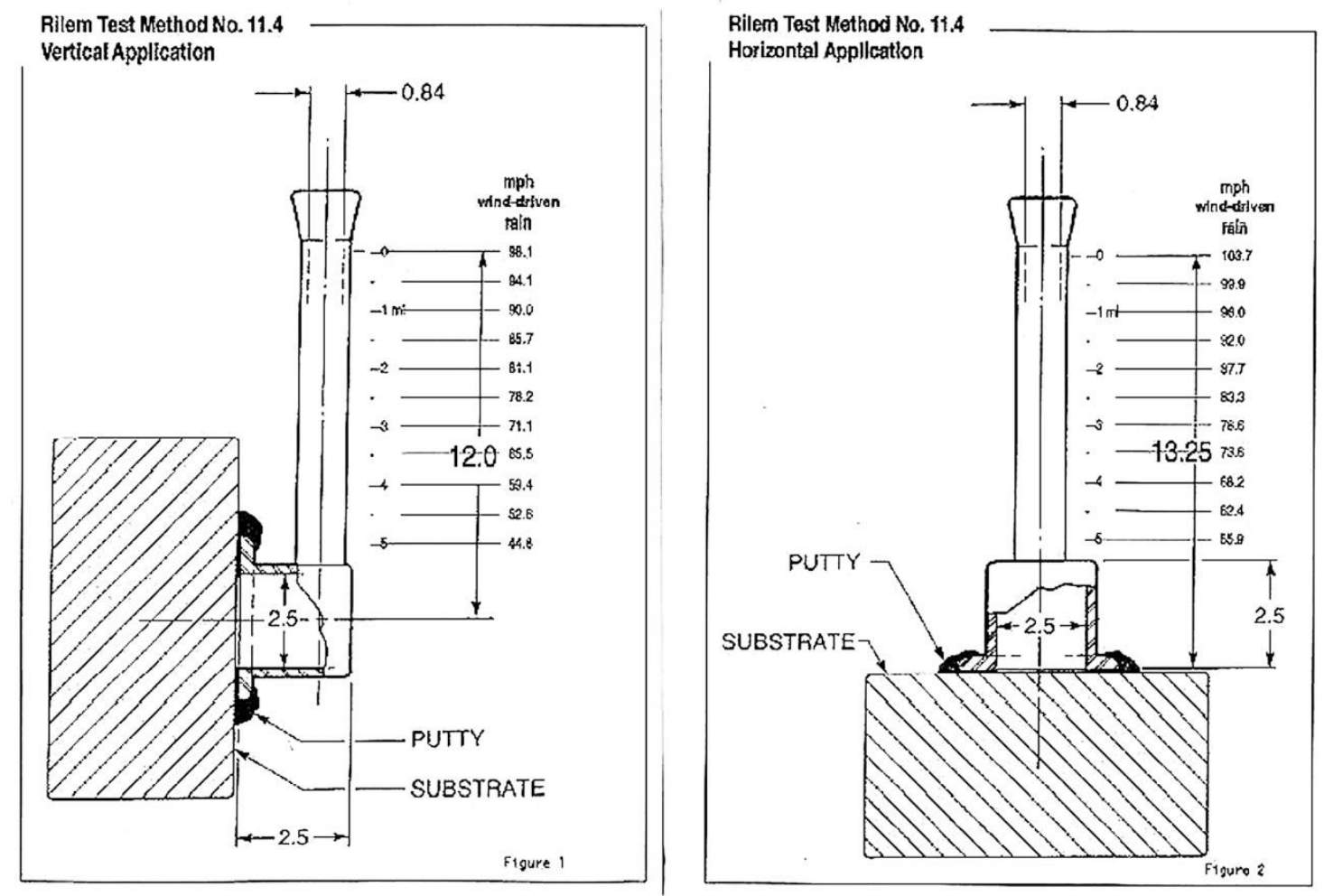

Figura 5.5. Teste do cachimbo. Fonte: RILEM 2006.

Unidades de alvenaria padrão apresentam desafios com relação à absorção de água, já que a alta porosidade e uma eficiente capilaridade implicam que a tecnologia de repelentes de água seja ineficaz. Procedimentos de campo têm sido revisados para incorporar técnicas adequadas para estes materiais. 
O teste de absorção de água é realizado utilizando-se o método do cachimbo, de acordo com o procedimento descrito na recomendação da RILEM - Reunion Internationale des Laboratoires d'Essais et de Recherches sur les Materiaux et les Constructions - RILEM 25 PEM (1980, revisado em 2006), mais especificamente o RILEM II.4.

A RILEM é a união internacional de laboratórios de pesquisa e teste para materiais e estruturas. Assim como no ASTM (American Society for Testing and Materials), Comitês Técnicos são formados na RILEM para desenvolver métodos padrões para medir propriedades e avaliar o desempenho e a durabilidade de materiais de construção.

Um desses comitês, a Comissão 25-PEM acima citada, desenvolveu testes para medir a deterioração da pedra e avaliar a eficiência dos métodos de tratamento. Há vários testes feitos pela Comissão 25-PEM, incluindo métodos para determinação de coesão interna (III.), medição de propriedades superficiais mecânicas (IV.), e para detecção da presença e movimento da água (II.). O teste n. II.4 foi idealizado para medir a quantidade de água absorvida pela superfície de um material de alvenaria por um período de tempo definido.

O RILEM Test Method II.4 é uma forma simples para medir a taxa na qual a água se movimenta em materiais porosos tais como o de alvenaria. O teste pode ser feito no campo ou no laboratório e pode ser usado para medir transporte de água vertical ou horizontal, caracterizando desta forma se o material encontra-se intemperizado, apresentando alta permeabilidade, ou não.

O tubo RILEM de $60 \mathrm{mph}$ foi concebido para o uso em substratos de unidades de alvenaria padrão. Os destaques deste novo formato incluem uma borda maior para facilitar a aderência em superfícies rugosas, uma ranhura na borda para ajudar a colocação do selante e graduação por milhas por hora.

A água está muito associada aos processos de deterioração que afetam os materiais de alvenaria. Sua presença no interior dos poros resulta em destruição física do material submetido a ciclos de saturação/secagem ou congelamento/degelo. Este último é particularmente danoso se o material tem alto conteúdo de minerais argilosos expansivos. Gases poluentes são perigosos quando dissolvidos em água, sendo que a umidade é um requisito para o crescimento de organismos biológicos. Por causa desses fatores, a permeabilidade de água em um material de construção está diretamente relacionada à sua durabilidade.

O teste RILEM pode ser usado também para avaliar o desempenho de tratamento de repelente de água. Um tratamento efetivo reduziria substancialmente a permeabilidade do material. Uma comparação dos testes obtidos em superfícies tratadas e não tratadas fornece informação do grau de proteção que o tratamento com repelente de água oferece.

Ferreira Pinto et al. (1996a) usaram o método do cachimbo para medir a absorção de água em rochas graníticas, para medir a eficácia de repelentes de água. A absorção de água em granitos levemente alterados variou de 0,175 a $0,325 \mathrm{~cm}^{3}$ e em granitos moderadamente alterados variou de 0,600 a $0,800 \mathrm{~cm}^{3}$.

O procedimento para realizar o teste de absorção de água com o cachimbo é afixá-lo com um selante no material a ser analisado. Para assegurar esta adesão, é exercida uma pressão manual no cilindro. A seguir acrescenta-se água até a primeira marca da graduação e é lida 
no tubo graduado a quantidade de água absorvida pelo material durante um período de tempo especificado. O período de tempo apropriado para o teste depende da porosidade do material, geralmente com intervalos de $5 \mathrm{~min}, 10 \mathrm{~min}, 15 \mathrm{~min}, 20 \mathrm{~min}, 30 \mathrm{~min}$ e $60 \mathrm{~min}$. Em muitos casos, pode ser importante medir a absorção de água nas juntas de argamassa tanto quanto na superfície do material a ser analisado (tijolo ou pedra natural).

A primeira dificuldade operacional do teste é a própria fixação do cachimbo na pedra, tarefa aparentemente simples, mas que necessita de uma certa prática para se efetuar o selamento completo do aro do cachimbo (Figura 5.6). O argilito® (massa cerâmica pronta para ser moldada), apesar de sua facilidade no manuseio, desintegra-se após algum tempo em contato com a água. A massa de modelar não apresenta este problema, mas mancha a pedra. A melhor solução é o uso de hidrocolóide irreversível, também conhecido como alginato, e sua grande vantagem é a facilidade de remoção (Rodrigues 2012).
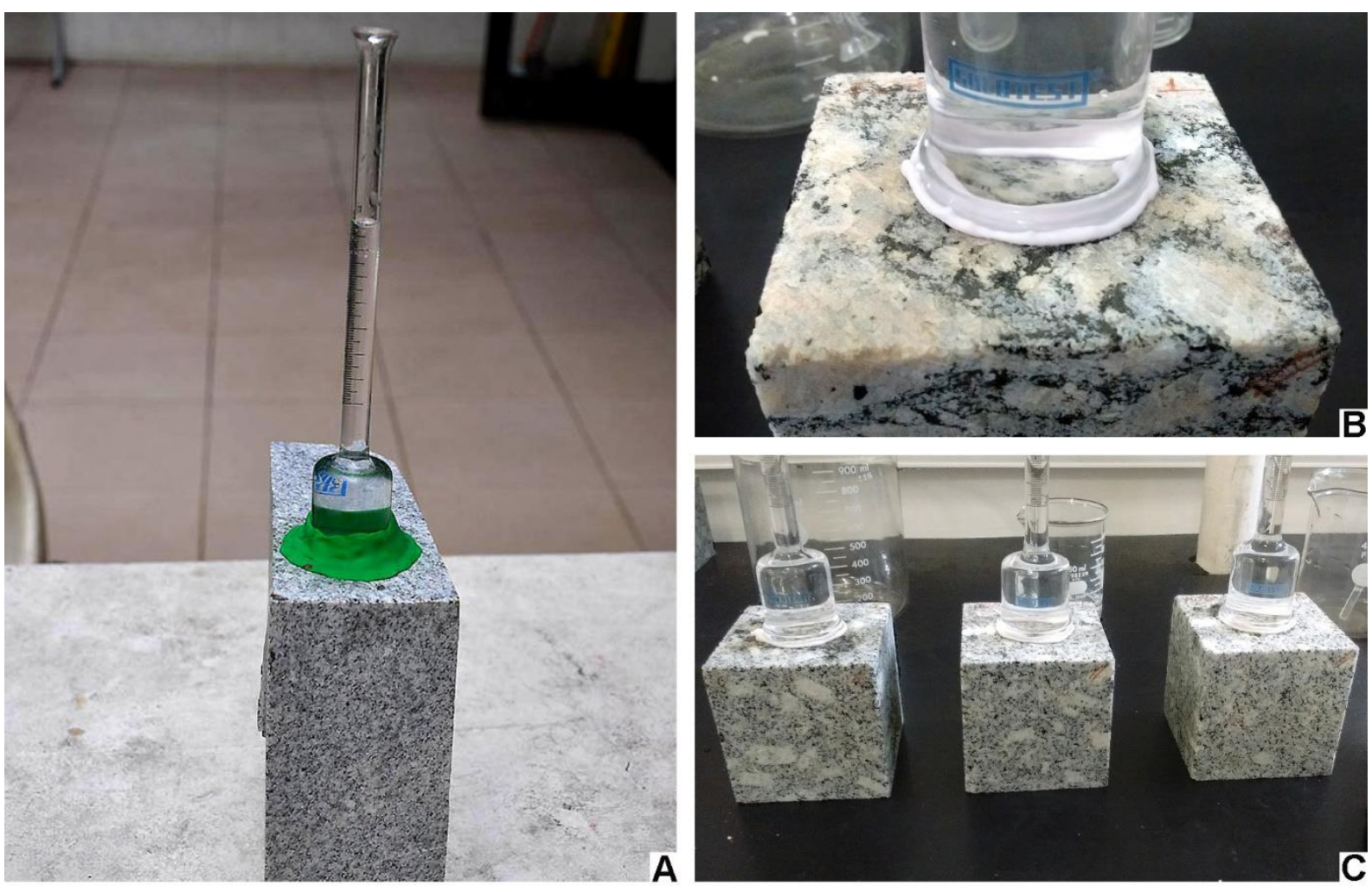

A
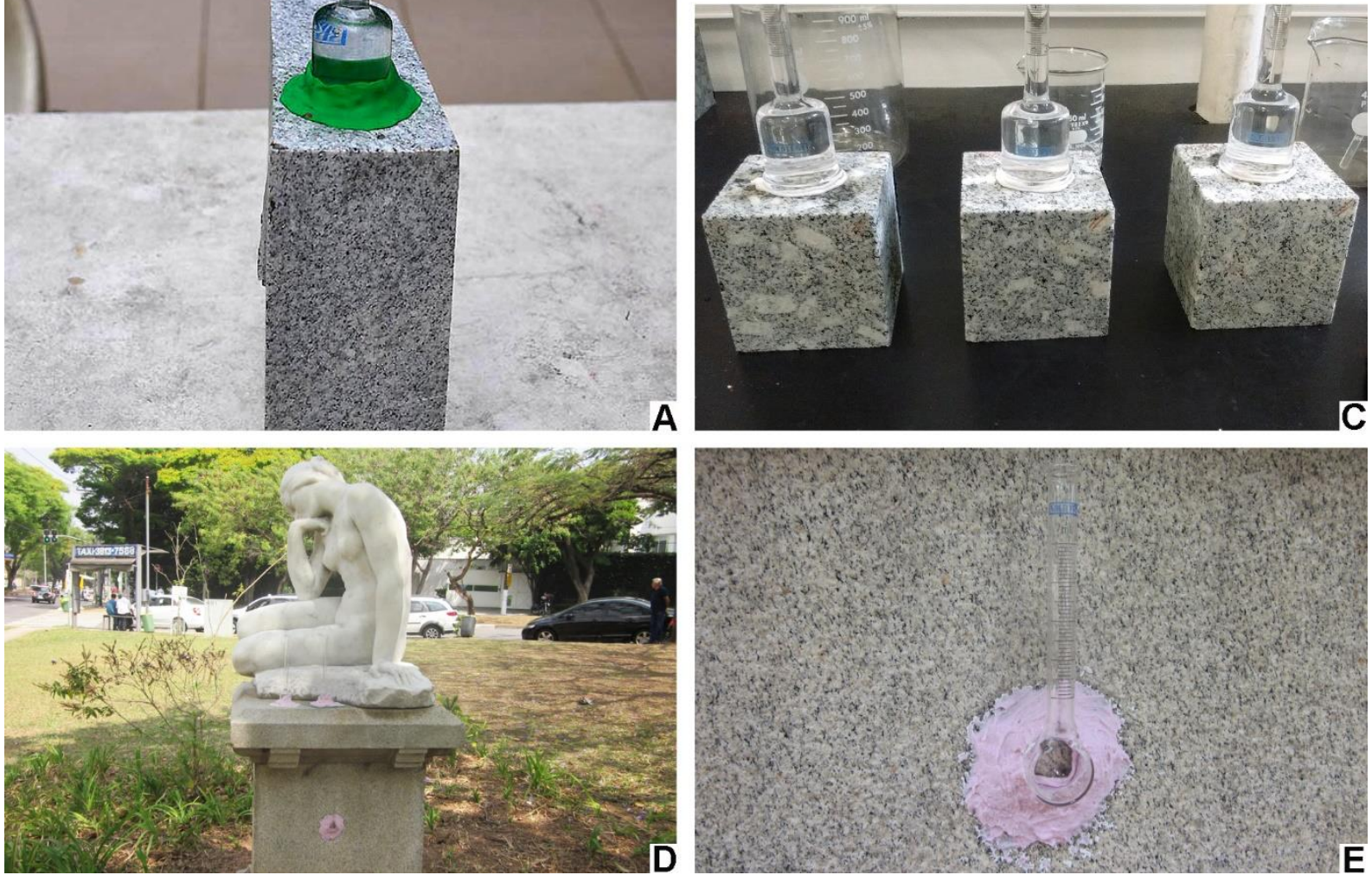

Figura 5.6. Teste de absorção de água. A. Fixação do tubo de Karsten com massa de modelar. B. Fixação do tubo de Karsten com alginato. C. Ensaio no Granito Cinza Mauá. D. Ensaio no Granito Itaquera, monumento Nostalgia, São Paulo. E. Detalhe de D. Fotografias B e C: Alexander M.S. Gimenez, D e E: Natália M. Rodrigues. 


\section{REFERÊNCIAS}

ABNT - Associação Brasileira de Normas Técnicas. 1994. NBR 8802: Concreto endurecido Determinação da velocidade de onda ultra-sônica. Rio de Janeiro. 8 p.

ABNT - Associação Brasileira de Normas Técnicas. 1995. NBR 7584: Concreto endurecido Avaliação da dureza superficial pelo esclerômetro de reflexão. Rio de Janeiro. 9 p.

Álvarez A.R., Redondo F.M., Menéndez L.V. 2008. Consolidation of granite building stones used in continental climates: San Juan de los Reyes Church in Toledo, Spain. In: Delgado Rodrigues J. \& Mimoso J.M. (eds.) International Symposium Stone Consolidation in Cultural Heritage - research and practice. Lisbon, LNEC, Proceedings, p. 213-222.

ASTM - American Society for Testing and Materials. 2000. D 5873: Standard test method for determination of rock hardness by rebound hammer method. West Conshohocken (PA, EUA), $4 \mathrm{p}$.

ASTM - American Society for Testing and Materials. 2008. D 2845: Standard method for laboratory determination of pulse velocities and ultrasonic elastic constants of rock. Philadelphia. $7 \mathrm{p}$.

ASTM - American Society for Testing and Materials. 2016. C-597: Standard test method for pulse velocity through concrete. West Conshohocken (PA, EUA). 4 p.

Aufmuth R.E. 1973. A systematic determination of engineering criteria for rocks. Bulletin of the Association of Engineering Geology, 11:235-245.

Augusto W.C.B. 2009. Caracterização geológica dos monumentos da cidade de São Paulo. Monografia de Trabalho de Formatura, Instituto de Geociências, Universidade de São Paulo (IGc-USP), $41 \mathrm{p}$.

Aydin A. 2009. ISRM Suggested method for determination of the Schmidt hammer rebound hardness: Revised version. International Journal of Rock Mechanics \& Mining Sciences, 46:627-634.

Aydin A. \& Basu A. 2005. The Schmidt hammer in rock material characterization. Engineering Geology, 81:1-14.

Benavente D., Martínez-Verdú F., Bernabeu A., Viqueira V., Fort R., García del Cura M.A., Illueca C., Ordóñez S. 2003. Influence of surface roughness on color changes in building stones. Color Research and Application, 28(5):343-351.

Berns R.S., Byrns S., Casadio F., Fiedler I., Gallagher C., Imai F.H., Newman A., Taplin L.A. 2006. Rejuvenating the color palette of Georges Seurat's A Sunday on La Grande Jatte - 1884: a simulation. Color Research and Application, 31(4):278-293.

Bobin O., Schvoerer M., Ney C., Rammah M., Pannequin B., Cilia Platamone E., Daoulatli A., Gayraud R.P. 2003. The role of copper and silver in the colouration of metallic luster decorations (Tunisia, $9^{\text {th }}$ Century; Mesopotamia, $10^{\text {th }}$ Century; Sicily, $16^{\text {th }}$ Century): A First Approach. Color Research and Application, 28(5): 352-359. 
BS - British Standards. 2004. BS EN 12504: Testing concrete. Determination of ultrasonic pulse velocity. $14 \mathrm{p}$.

Burgess C. \& Jones D.G. 1995. Spectrophotometry, luminescence and colour; science and compliance. New York, Elsevier, 439 p.

Buyuksagis I.S. \& Goktan R.M. 2007. The effect of Schmidt hammer type on uniaxial compressive strength prediction of rock. International Journal of Rock Mechanics \& Mining Sciences, 44:299-307.

Costa D. \& Delgado Rodrigues J. 1996. Assessment of colour changes due to treatment products in heterochromatic stones. In: Delgado Rodrigues J., Costa D. (eds.) Conservation of granitic rocks. Lisbon, LNEC, p. 95-101.

Costa D. \& Delgado Rodrigues J. 2008. Evaluation of consolidation treatments applied to granitic materials. Experience and critical overview of laboratory testing. In: Delgado Rodrigues J. \& Mimoso J.M. (eds) International Symposium Stone Consolidation in Cultural Heritage research and practice. Lisbon, LNEC, Proceedings, p.389-398.

Del Lama E.A., Dehira L.K., Grossi D., Kuzmickas L. 2016. The colour of the granite that built the city of São Paulo, Brazil. Color Research and Application, 41(3): 241-245.

Delgado Rodrigues J. 1978. About the quantitative determination of rock weatherability. A case history. In: III International Congress I.A.E.G., Proceedings, Sec. II, v. 1, pp. 65-71.

Delgado Rodrigues J. \& Costa D. 2008. The conservation of granite in Évora Cathedral. From laboratory to practice. In: Delgado Rodrigues J. \& Mimoso J.M. (eds) International Symposium Stone Consolidation in Cultural Heritage - research and practice. Lisbon, LNEC, Proceedings, p.101-110.

Delgado Rodrigues J., Costa D., Schiavon N. 1996. Spatial distribution in granite stones. In: Delgado Rodrigues J. \& Costa D. (eds.) Conservation of granitic rocks. Lisboa, LNEC, p. 5561.

Feliu M.J., Edreira M.C., Martín J., Calleja S., Ortega P. 2005. Study of Various Interventions in the Façades of a Historical Building - Methodology Proposal, Chromatic and Material Analysis. Color Research and Application, 30(5):382-390.

Ferreira Pinto A.P., Delgado Rodrigues J., Costa D., Schiavon N. 1996a. Assessment of the efficacy and harmfulness of water repellents in granite. In: Delgado Rodrigues J. \& Costa D. (eds.) Conservation of granitic rocks. Lisboa, LNEC, p. 29-41.

Ferreira Pinto A.P., Delgado Rodrigues J., Costa, D. 1996b. Behaviour of water repellents in granites under accelerated ageing tests. In: Delgado Rodrigues J. \& Costa D. (eds.) Conservation of granitic rocks. Lisboa, LNEC, p. 43-54.

Fort R., Mingarro F., López de Azcona M.C., Rodriguez Blanco J. 2000. Chromatic Parameters as Performance Indicators for Stone Cleaning Techniques. Color Research and Application, 25(6):442-446.

Franceschi E., Letard, P., Luciano G. 2006. Colour measurements on patinas and coating system for outdoor bronze monuments. Journal of Cultural Heritage, 7:166-170. 
García-Talegon, J., Vicente, M.A., Vicente-Tavera S., Molina-Ballesteros E. 1998. Assessment of Chromatic Changes Due to Artificial Ageing and/or Conservation Treatments of Sandstones. Color Research and Application, 23(1):46-51.

Gimenez A.M.S. 2012. Avaliação do Comportamento da Aplicação de Ondas Ultrassônicas no Monumento às Bandeiras. Dissertação de Mestrado, Instituto de Geociências, Universidade de São Paulo (IGc-USP), 73 p. Disponível em: http://www.teses.usp.br/teses/disponiveis/44/44144/tde-17072013-160135/pt-br.php.

Gimenez A.M.S. \& Del Lama E.A. 2014. Comportamento de ondas ultrassônicas no Granito Mauá para a conservação do Monumento às Bandeiras. Geologia USP - Série Científica, Revista do Instituto de Geociências-USP, 14(3):47-60. Disponível em: http://ppegeo.igc.usp.br/pdf/guspsc/v14n3/04.pdf.

Gonçalves A.E.N. 2010. Estudo da influência dos factores de aplicação no desempenho de argamassas de revestimento recorrendo a técnicas de ensaio in-situ. Dissertação de Mestrado, Instituto Técnico Superior, Lisboa, 158 p.

Grossi C.M. \& Brimblecombe P. 2007. Effect of long-term changes in air pollution and climate on the decay and blackening of European stone buildings. In: Prikryl R. \& Smith B.J. (eds.) Building Stone Decay: From Diagnosis to Conservation. London, Geological Society, Special Publications, 271:117-130.

Grossi C.M., Brimblecombe P., Esbert R.M., Alonso F.J. 2007a. Color Changes in Architectural Limestones from Pollution and Cleaning. Color Research and Application, 32(4): 320-331.

Grossi C.M., Alonso F.J., Esbert R.M., Rojo A. 2007b. Effect of Laser Cleaning on Granite Color. Color Research and Application, 32(2):152-159.

Grossi D. 2013. Análise do estado de conservação do Monumento a Ramos de Azevedo com utilização de métodos não destrutivos. Dissertação de Mestrado, Instituto de Geociências, Universidade de São Paulo (IGc-USP), 138 p. Disponível em: http://www.teses.usp.br/teses/disponiveis/44/44144/tde-14112013-105630/.

Grossi D. \& Del Lama E.A. 2015. Ultrasound technique to assess the physical conditions of the Monument to Ramos de Azevedo. Revista Escola de Minas (REM), 68(2): 171-176. Disponível no endereço: http://www.scielo.br/pdf/rem/v68n2/0370-4467-rem-68-02-0171.pdf.

Grossi D., Del Lama E.A., Garcia-Talegon J., Iñigo A.C., Vicente-Tavera S. 2015. Evaluation of colorimetric changes in the Itaquera granite of the Ramos de Azevedo Monument, São Paulo, Brazil. International Journal of Conservation Science, 6:313-322. Disponível em: http://ijcs.uaic.ro/public/IJCS-15-29_Grossi.pdf.

Iñigo A.C., Vicente-Tavera S., Rives V., Vicente M.A. 1997. Color Changes in the Surface of Granitic Materials by Consolidated and/or Water Repellent Treatments. Color Research and Application, 22(2):133-141.

ISRM - International Society for Rock Mechanics. 1978. Sugested method for determination of the Schmidt rebound hardness. In: Brown E.T. (ed.) Rock characterization - Test and monitoring. ISRM Suggested methods. London, Pergamon Press, 1981, p.101-102. 
Johnston, S. F. 1996. The construction of colorimetry by committee. Science in context, 9:(4):387-420. Disponível em: http://eprints.gla.ac.uk/2904/1/constuction_of_colorimetry.pdf.

Katz O., Reches Z., Roegiers J.C. 2000. Evaluation of mechanical rock properties using a Schmidt Hammer. International Journal of Rock Mechanics \& Mining Sciences, 37:723-728.

Kuzmickas L. 2013. Estado de conservação dos monumentos pétreos do Cemitério da Consolação, São Paulo. Dissertação de Mestrado, Instituto de Geociências, Universidade de

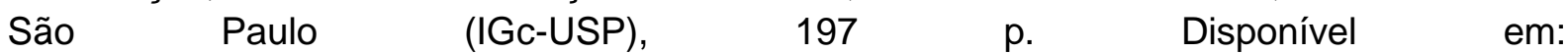
http://www.teses.usp.br/teses/disponiveis/44/44144/tde-18112013-104436/.

Kuzmickas L. \& Del Lama E.A. 2014. Utilização de métodos não destrutivos no patrimônio histórico: estudo de caso da escultura O Sepultamento de Victor Brecheret. Revista Brasileira de Geologia de Engenharia e Ambiental (RBGEA), 4(1):9-22. Disponível em: http://www.abge.org.br/uploads/arquivos/artigo1-dellama2015100813351380545.pdf.

Machado D.F.R. 2015. Catedral da Sé de São Paulo: análise do estado de conservação das rochas do templo por métodos não destrutivos. Dissertação de Mestrado, Instituto de Geociências, Universidade de São Paulo (IGc-USP), 180 p. Disponível em: http://www.teses.usp.br/teses/disponiveis/44/44144/tde-27052015-090139/.

Mariani A., Cappelletti P., Brunetti A., Bidali S., Alzari V., Caria G., Colella A., Nuvoli D., Pini M. 2008. Frontal polymerization: a new approach to the consolidation of stone? In: Delgado Rodrigues J., Mimoso J.M. (eds.) International Symposium Stone Consolidation in Cultural Heritage - research and practice. Lisbon, LNEC, Proceedings, p.91-100.

Mori E.K. 2015. Estudo da paleta de cores do artista Alfredo Volpi utilizando métodos de análise física não destrutivos por meio dos equipamentos de Espectrofotômetro, Espectômetro de Energia Dispersiva - EDXRF e Microscópio Eletrônico de Varredura - MEV. Dissertação de Mestrado, Instituto de Geociências, Universidade de São Paulo (IGc-USP), 257 p. Disponível em: http://www.teses.usp.br/teses/disponiveis/44/44144/tde-17112015$151200 /$.

Mori E.K., Del Lama E.A., Rizzuto M.A., Kajiya E.M., Campos P.H.O.V. 2016. Analyses of Alfredo Volpi's paintings with X-rays fluorescence, spectrophotometer and multispectral imaging. Submetido ao E-Conservation.

Murray H.D. 1952. Colour in theory and practice. London, Chapman \& Hall, 360 p.

Nassau K. 1998. Color for science, art and technology. Amsterdam, Elsevier, 491 p.

Nassau K. 2001. The physics and chemistry of color: the fifteen causes of color. New York, John Wiley \& Sons, 481p.

Pamplona M., Kocher M., Snethlage R., Wendler E. 2008. Consolidation effectiveness of TEOS on Ançã limestone from Portugal - A laboratory study. In: Delgado Rodrigues J., Mimoso J.M. (eds.) International Symposium Stone Consolidation in Cultural Heritage research and practice. Lisbon, LNEC, Proceedings, p.183-192.

Prieto B., Sanmartín P., Silva B., Martínez-Verdú F. 2010. Measuring the color of granite rocks: a proposed procedure. Color Research and Application, 35(5):368-375. 
RILEM - Réunion Internationale des Laboratoires et Experts des Matériaux, systems de construction et ouvrages. 1980. TC 25-PEM. Recommandations provisoires. Essais recommandés pour mesurer l'altération des pierres et évaluer l'efficacité des methods de traitement. Matériaux et Construction, 13(75):177-179.

RILEM - Réunion Internationale des Laboratoires et Experts des Matériaux, systems de construction et ouvrages. 2006. Water Absorption Tube Test. RILEM II.4. 4 p.

Rodrigues N.M. 2012. Ensaios não destrutivos em monumentos pétreos paulistanos. Monografia de Trabalho de Formatura, Instituto de Geociências, Universidade de São Paulo (IGc-USP), 75 p.

Rodríguez-Gordillo J., Sáez-Pérez M.P., Durán-Suárez J.A., García-Beltrán A. 2007. Chromatic behavior of inorganic pigments in restoration mortars (nonhydraulic lime, hydraulic lime, gypsum, and portland cement). A comparative study. Color Research and Application, 32(1):65-70.

Sánchez J.S., Alves C.A.S., Romaní J.R.V., Mosquera D.F. 2008. A porosity study of granite ashlars to apply consolidation treatments in an historic building in the city A Coruña (NW Spain). In: Delgado Rodrigues J., Mimoso J.M. (eds.) International Symposium Stone Consolidation in Cultural Heritage - research and practice. Lisbon, LNEC, Proceedings, p.329337.

Schaffer R.J. 1932. The weathering of natural building stones. Donhead Publishing Ltd., 149 p. (Reimpressão em 2004).

Scherer G.W. \& Jiménez-Gonzaléz I. 2008. Swelling clays and salt crystallization: damage mechanisms and the role of consolidants. In: Delgado Rodrigues J., Mimoso J.M. (eds.) International Symposium Stone Consolidation in Cultural Heritage - research and practice. Lisbon, LNEC, Proceedings, p.29-39.

Souza J.C., Rolim Filho J.L., Barros M.L.S.C., Lira B.B. Silva S.A., Rieck F.E. 2008. Análise colorimétrica de rochas ornamentais. Estudos Geológicos, 18(1):55-64.

Spathis P., Papasstergiadis E., Christaras B., Mavromati M., Loukma M. 2008. Deterioration problems and preliminar observations on the conservation of the building materials of excavations of Navarino and Diikitirio, Thessaloniki. In: Delgado Rodrigues J., Mimoso J.M. (eds.) International Symposium Stone Consolidation in Cultural Heritage - research and practice. Lisbon, LNEC, Proceedings, p.141-149.

Teixeira R.B., Silva V.F.da, Barroso E.V. 2008. O Martelo de Schmidt como ferramenta de avaliação da degradação de rochas de cantaria em prédios históricos. In: 12․ Congresso Brasileiro de Geologia de Engenharia e Ambiental, Porto de Galinhas, Anais. CD-ROM.

Xu S., Grasso P., Mahtab A. 1990. Use of Schmidt hammer for estimating mechanical properties of weak rock. In: $6^{\text {th }}$ International IAEG Congress, Balkema, Rotterdam, Proceedings, v. 1, p. 511-519. 


\section{Cal e Argamassa}

Antigamente, as paredes nas construções históricas eram construídas sem argamassa, como fizeram os incas ou culturas por eles influenciadas (Figura 6.1), ou foram construídas com utilização de argamassa de cal, que foi o mais comum, apesar de outros tipos de materiais também terem sido usados. As argamassas antigas têm grande durabilidade e resistência, visto que ainda hoje existem vários exemplos onde elas podem ser encontradas em bom estado de conservação.

A cal, só ou associada com outros componentes, como a pozolana, foi o principal aglomerante usado nas argamassas até o início do século XIX, tendo sido progressivamente substituída pelo cimento Portland.
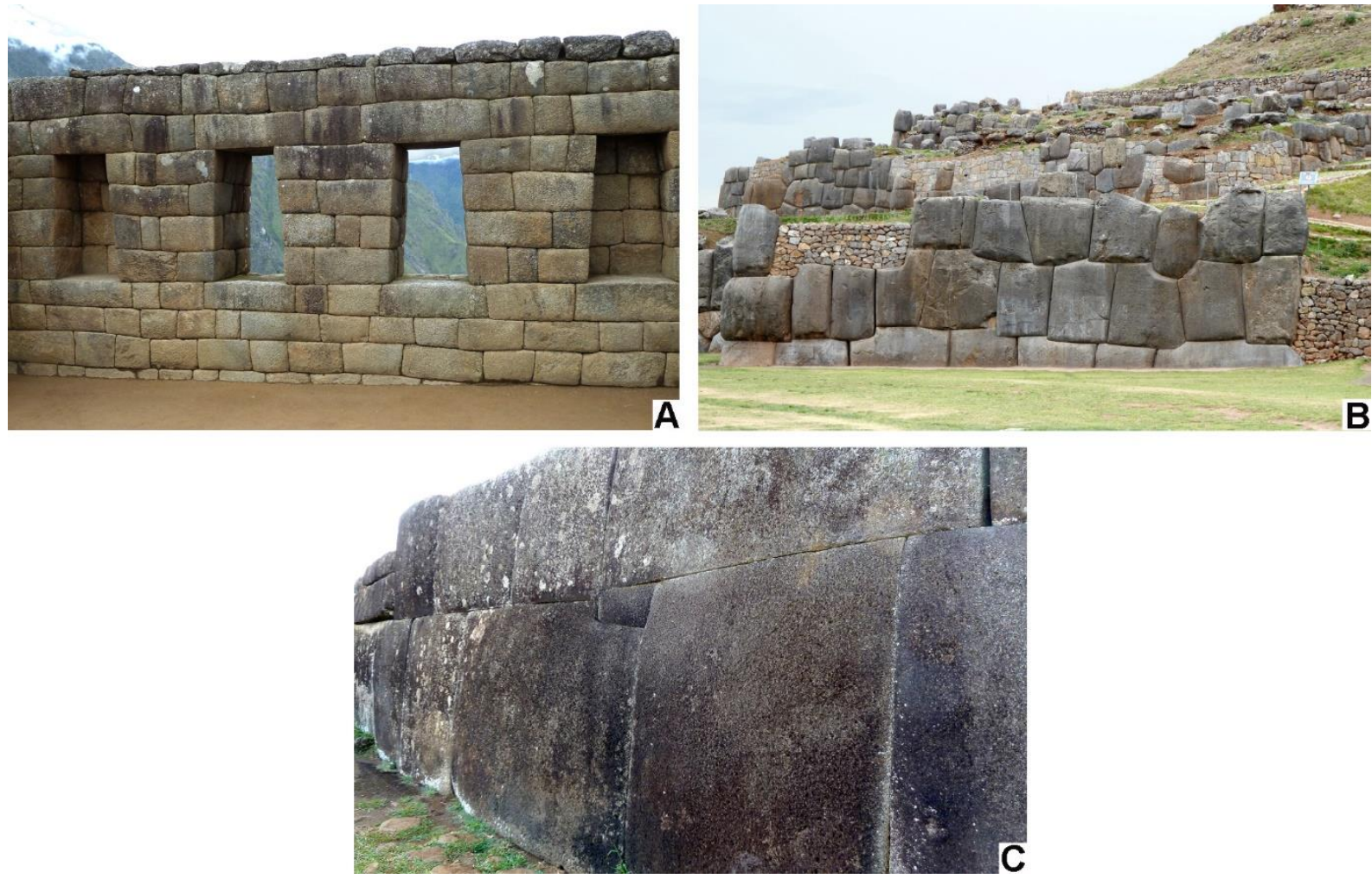

Figura 6.1. Construções sem argamassa ou parede-seca. A. Santuário de Machu Picchu, Peru. B. Sítio Arqueológico de Saqsaywaman, Cusco, Peru. C. Sítio Arqueológico de Vinapu, Ilha de Páscoa, Chile - acredita-se que esta técnica de construção é similar a dos incas. 
Uma argamassa pode ter diferentes funções, quais sejam: prover uma camada na qual a carga da parede é distribuída uniformemente, unir blocos de alvenaria, rejuntar pisos e paredes, revestir paredes externas (renders em língua inglesa), revestir paredes internas (plasters) e também como um material de substituição de pedras degradadas (Figura 6.2).

Vitruvius dizia que a argamassa ocupava o primeiro lugar entre os revestimentos.
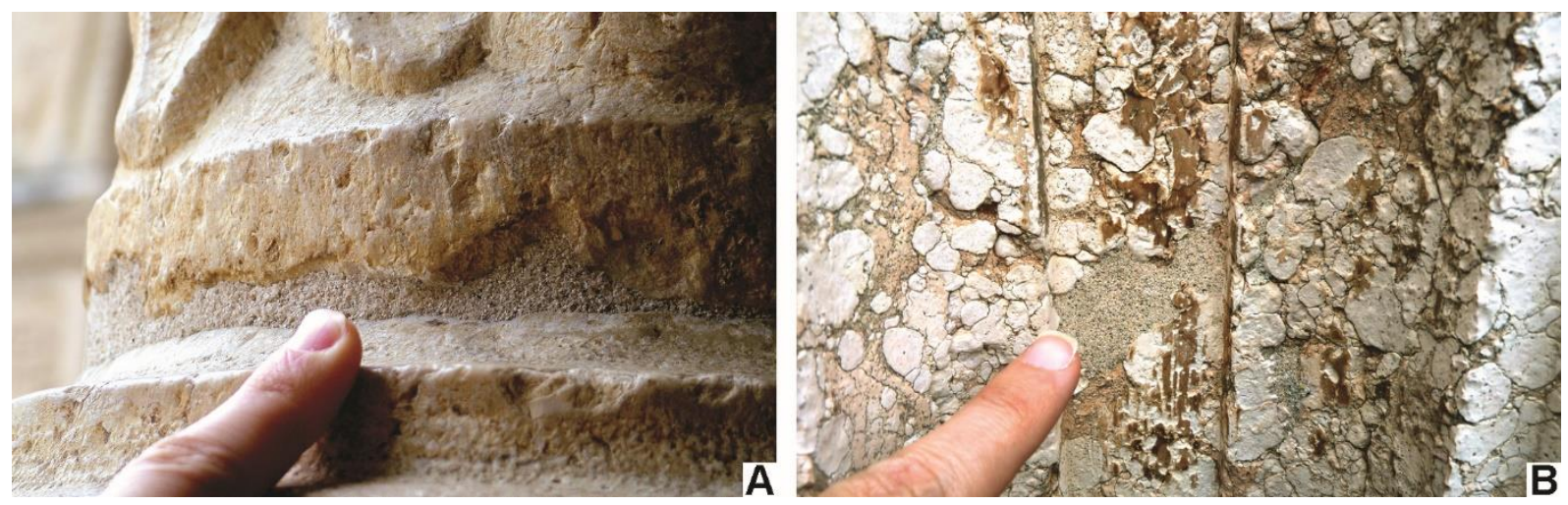

Figura 6.2. Argamassa preenchendo vazios. A. Mosteiro dos Jerónimos, Lisboa, Portugal. B. Edifício em Veneza, Itália.

A utilização da cal é bastante antiga. Em cavernas de calcário usadas como abrigo, os blocos das paredes eram usados na fogueira, transformando-se em óxido de cal. Com a umidade do interior da caverna, após a retirada desse material do fogo, transformava-se em cal hidratada e posteriormente reagindo $\mathrm{com} \mathrm{CO}_{2}$ do ar, transformava-se em calcita. Este era o pigmento branco usado nas pinturas rupestres paleolíticas.

Foram encontrados vestígios de cal utilizada na construção da muralha de Jericó $(9.000$ a.C.) e estátuas de argamassa de cal em Ain Ghazal, na Jordânia (6.500 a.C.).

O ponto inicial documentado da história da cal nos pavimentos deu-se em 5.600 a.C. em Lepenski Vir, localizado na margem esquerda do Rio Danúbio, na Sérvia, ex-lugoslávia, conhecido como chão de cal vermelha (Figura 6.3).

$\mathrm{Na}$ Antiguidade, os egípcios utilizaram argamassa de gesso, material este abundante nas margens do Rio Nilo, sendo que na pirâmide de Quéops (2.600 a.C.) ainda se observa revestimento deste material.

Os gregos e os romanos utilizaram argamassa de cal com adições pozolânicas, terras de Santorini e de Pozzuoli, respectivamente (Tavares 2011).

No Palácio de Knossos (Creta), o suporte dos afrescos foi confeccionado com duas camadas de argamassa com cal e fibras de cabelo (2.000 a.C.).

Os etruscos foram os primeiros a utilizar argamassa na construção de túmulos (800 a.C.).

A cal foi utilizada na construção das camadas inferiores da Via Ápia, Roma (312 a.C.), que consistia em 4 camadas, variando entre 0,9 e 1,5 m. 
A argamassa utilizada na Muralha da China (228 a.C.) foi confeccionada com uma mistura bem compactada de terra argilosa e cal, e eventuais adições de clara de ovo.

Entre outros monumentos famosos onde foi utilizada a cal tem-se o Pantheon e o Coliseu (Roma) (Figura 6.4), e a Pont Du Gard (França).
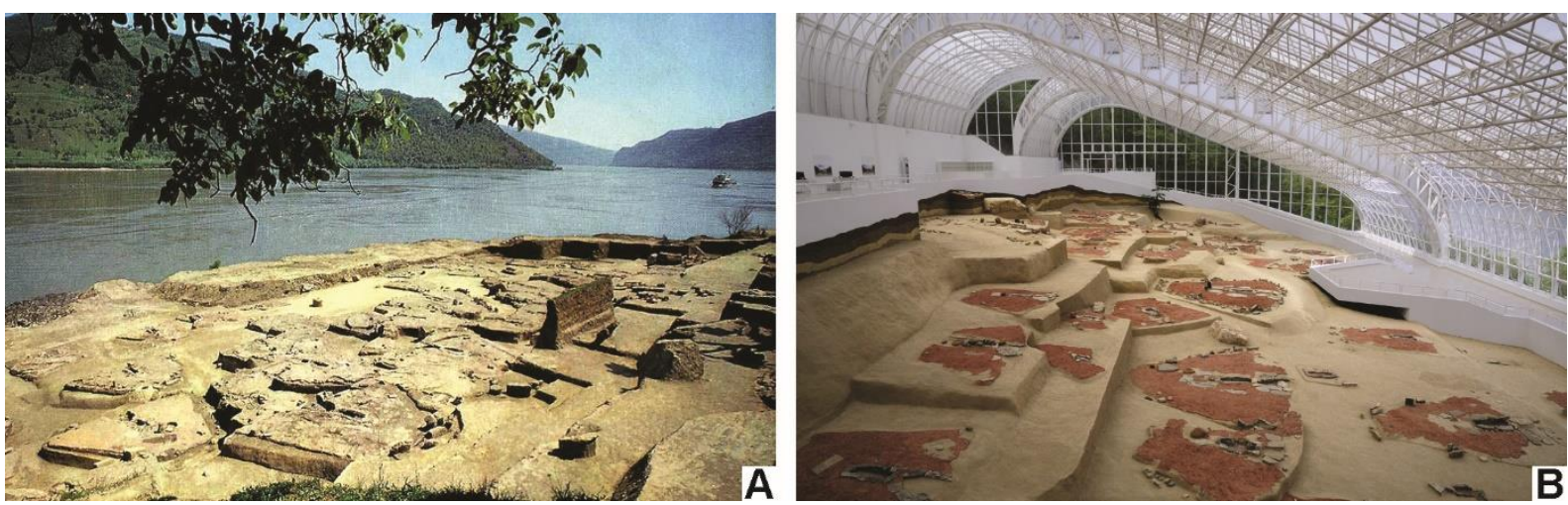

Figura 6.3. Registro de uso da cal na Antiguidade: Lepenski Vir, Sérvia. A. Ruínas arqueológicas antes da intervenção. Fonte: http://www.donsmaps.com/images7/lepenskicolour3.jpg. B. Após colocação de estrutura de proteção. Fonte:

https://upload.wikimedia.org/wikipedia/commons/5/51/Lepenski_Vir_(2).JPG.
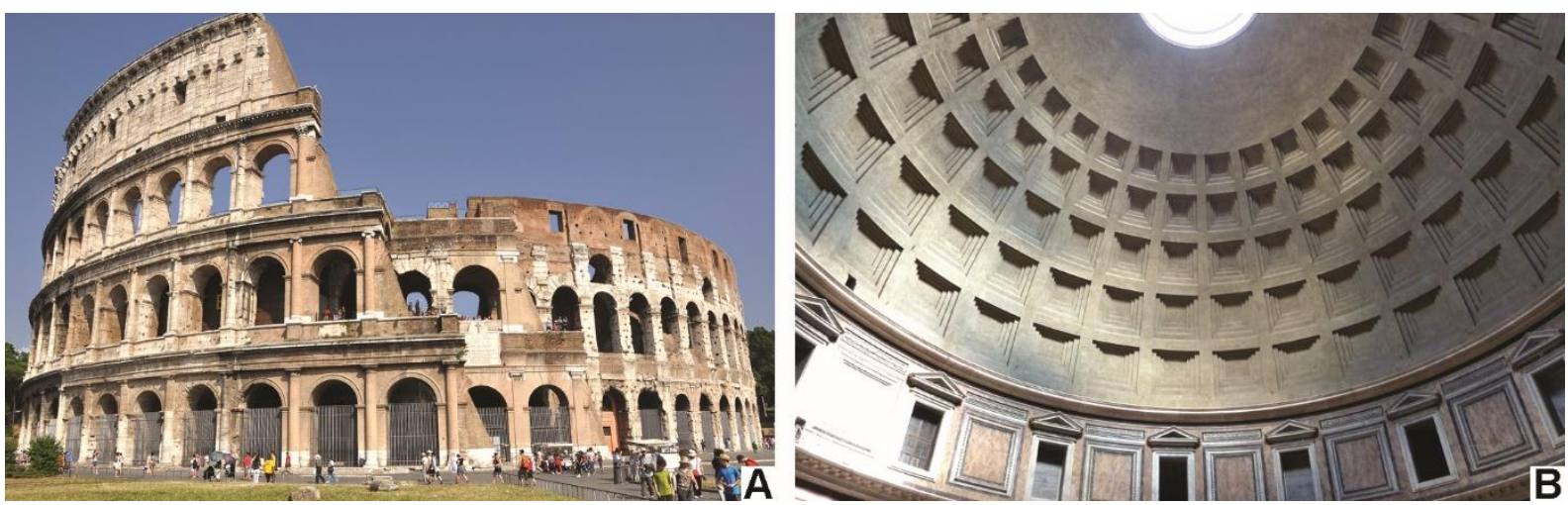

Figura 6.4. Monumentos históricos de Roma onde foram utilizadas argamassas hidráulicas ou cimento romano. A. Coliseu. B. Pantheon. Fotografias: Lauro K. Dehira

Em relação à argamassa de cal, os primeiros registros descrevendo seu uso foram realizados por Cato (234 - 149 a.C.), Vitruvius na obra De Architectura (27 a.C. - 14) e Plínio, o Jovem (62 - 113).

Por outro lado, Santiago (2007) aponta que a primeira referência sobre emprego de argamassas é encontrada no tratado de agricultura Rerum rusticarum de Marco Terencio Varrão (116 - 27 a.C.).

O início do uso da cal no Brasil dá-se em 1549 quando Thomé de Souza ordena a criação da 1a. mineração no Brasil, a partir de depósitos de calcário e conchas marinhas da Baía de 
Todos os Santos (Guimarães 1997). As antigas fábricas de cal de conchas eram denominadas caieiras.

A tradição oral reza que no Brasil Colonial utilizava-se óleo de baleia na confecção de argamassa. Apesar de referências da hidrofobicidade de argamassas em textos antigos, não há respaldo científico da utilização deste óleo na fabricação dessas antigas argamassas brasileiras (Santiago 1992, Pardal 1999).

Um material muito utilizado foram as conchas, que podem ser observadas nas construções do litoral brasileiro (Figura 6.5).
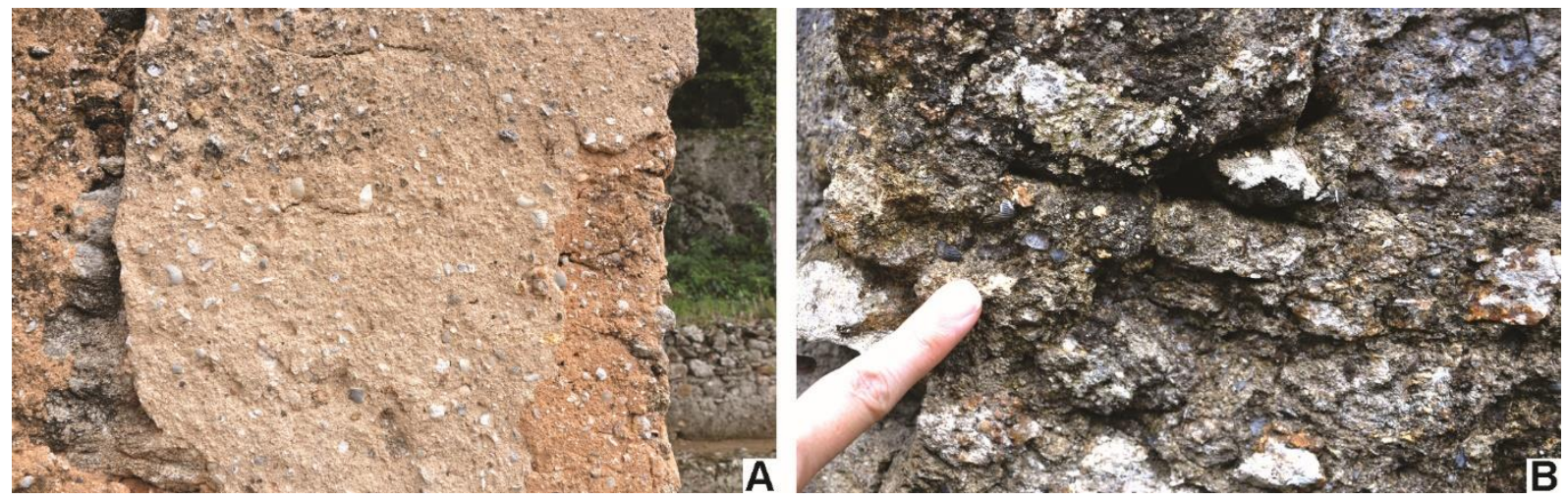

Figura 6.5. Utilização de conchas em argamassa em construções do litoral paulista. A. Sítio Arqueológico São Francisco, São Sebastão. B. Ruínas da Lagoinha, Ubatuba. Fotografias: Lauro K. Dehira.

Segundo Santiago (2007), a illita ou a caulinita foram utilizadas como um componente básico de argamassas de construção dos séculos XVII a XIX, o que lhes conferiam maior resistência à compressão.

Uma descrição dos materiais e as intervenções com argamassa na Conservação é encontrada em Ashurst (2002). Na bibliografia nacional, Santiago (2007) e Kanan (2008) abordaram o tema.

Atualmente, apenas $30 \%$ da cal fabricada no Brasil é usada na construção civil.

\subsection{Constituição e caracterização da argamassa}

A argamassa é constituída por aglomerante (cal, gesso, cimento), agregados e aditivos.

O aglomerante é um material em pó que, quando misturado com água, forma uma pasta, conseguindo aglutinar os agregados e originando a argamassa.

A cal foi o principal aglomerante utilizado até o século XVIII e está presente em maior porcentagem nas argamassas antigas. É definida como principal produto de calcinação de rochas calcárias. 
Segundo a ABNT, a cal é um produto composto predominante por óxido de cálcio ou por óxido de cálcio e magnésio, resultante da calcinação, à temperatura de $900-1.200^{\circ} \mathrm{C}$, de calcários, calcários magnesianos e dolomitos.

A principal matéria-prima para a produção de cal é o calcário, mas mármores, conchas marinhas e corais também podem ser usados.

A calcinação do calcário é uma reação endotérmica (43 kcal $/ \mathrm{mol}$ ) e origina $56 \%$ de CaO e $44 \%$ de $\mathrm{CO}_{2}$. Após a calcinação, a cal é hidratada, com posterior adição de agregados, para formar a argamassa. O endurecimento da argamassa se dá pela perda de água e incorporação de $\mathrm{CO}_{2}$. O material originado é quimicamente similar ao material inicial, mas com propriedades diferentes.

Todas estas transformações são melhores visualizadas no ciclo da cal da Figura 6.6 abaixo.

\section{O CICLO DA CAL}

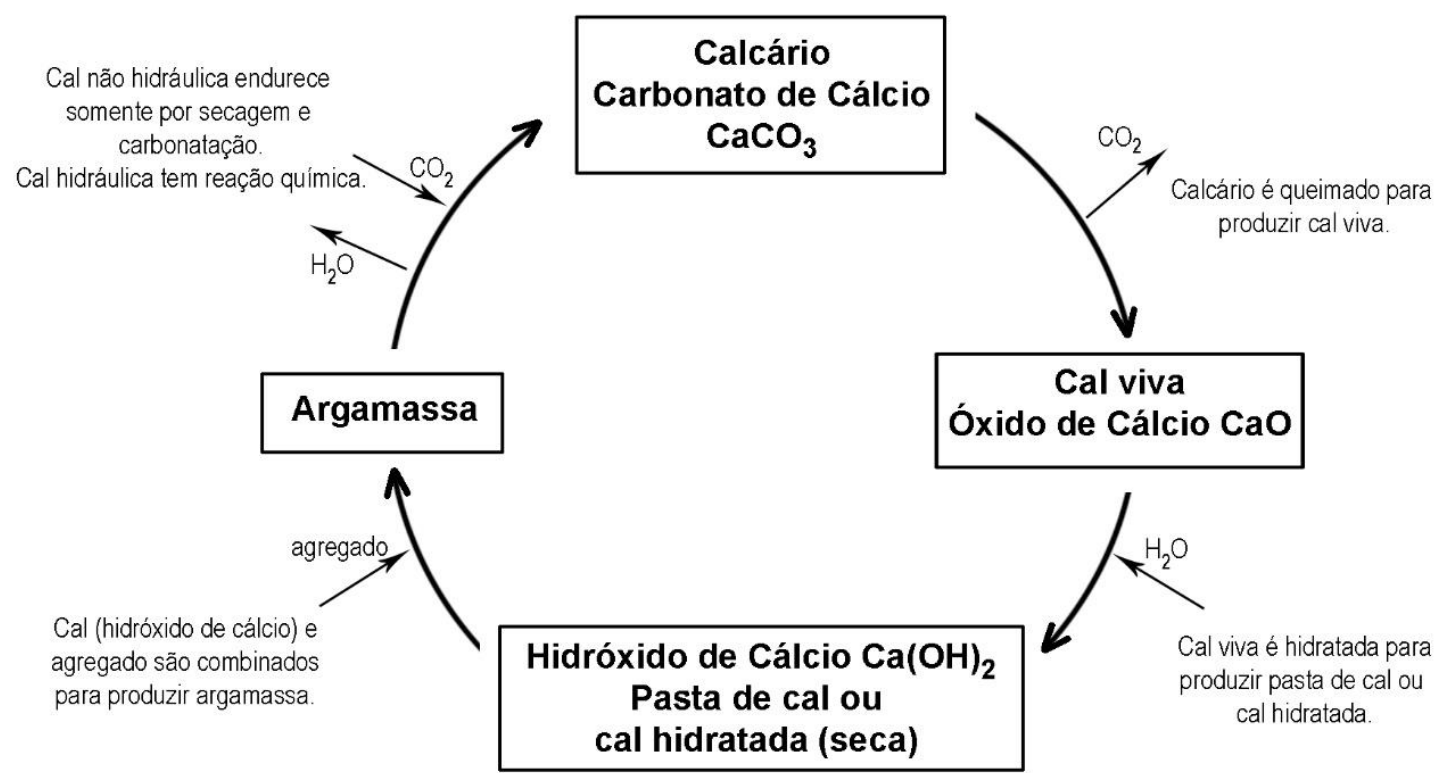

Figura 6.6. Ciclo da Cal.

O aglomerante de cal classifica-se em cal (não-hidráulica), cal hidráulica e cimento. A cal endurece e mantém a resistência mecânica apenas no ar. A cal hidráulica e o cimento são aglomerantes hidráulicos, ou seja, endurecem e mantêm a resistência mecânica no ar e na água.

A fonte da cal hidráulica são também os calcários, mas que contenham uma proporção de argilominerais entre 6 a 20\%. Quando calcinado, parte do CaO une-se aos óxidos de silício e alumínio, originando silicatos e aluminatos de cálcio, o que confere hidraulicidade à argamassa. 
A tecnologia da cal hidráulica desenvolveu-se no período romano e praticamente desapareceu até o século XVII. O cimento natural (romano) é eminentemente uma cal hidráulica. Foi patenteado primeiramente por Parker em 1796, e é conhecido como Cimento Romano. É formado pela queima de nódulos de mármore - calcário contendo alta proporção de argilominerais (ex. 'septária' de Harwich - UK, Boulogne - França e Louisville - USA).

O segundo aglomerante mais utilizado é o gesso, aglomerante não-hidráulico e oriundo da calcinação da gipsita. Este processo se dá a baixa temperatura, entre $110^{\circ}$ e $160^{\circ} \mathrm{C}$. Quando misturado com água, endurece rapidamente e ocorre leve expansão. Devido à sua alta solubilidade só deveria ser usado em ambientes internos. Entretanto, há exemplos de utilização da argamassa de gesso em ambientes externos na Inglaterra em construções do século XV e XVI.

$\mathrm{Na}$ cidade de São Paulo, foi encontrado gesso em argamassas, em pelo menos quatro prédios históricos: Estação da Luz, Museu de Zoologia, Edifício Itália e Capela do Hospital das Clínicas (Souza et al. 2008).

O aglomerante mais moderno e o mais usado atualmente é o cimento Portland, com pega mais rápida e mais resistente. Devido à sua incompatibilidade na substituição de argamassas históricas de cal em projetos de restauro, não será tratado aqui.

O agregado é um material inerte responsável pela estrutura da argamassa, representando aproximadamente $70 \%$ do material utilizado na confecção da argamassa. É constituído por areias e britas, sendo o mais comum utilizado na confecção das argamassas a areia quartzosa. O material deve ser lavado e estar sem impurezas, tais como, pirita, sais, impurezas orgânicas, micas ou quaisquer materiais alongados ou laminados em quantidade muito grande. Na seleção da areia, deve-se atentar para a sua natureza, cor, granulometria e formato dos grãos.

Quando a areia é utilizada como agregado, a argamassa adquire uma permeabilidade que faz com que $\mathrm{O} \mathrm{CO}_{2}$ atmosférico converta a portlandita $\left(\mathrm{Ca}\left(\mathrm{OH}_{2}\right)\right)$ da cal em calcita, após vários meses de sua exposição. Como os cristais de calcita são $12 \%$ maiores que os cristais da portlandita, a carbonatação reduz o tamanho dos poros, e consequentemente a porosidade.

A difusão do $\mathrm{CO}_{2}$ será reduzida se o tamanho dos poros na argamassa for inferior a $0,1 \mu \mathrm{m}$.

Em relação aos aditivos, eles podem ser anticongelantes (cloreto de cálcio, e em sendo de natureza salina deve ser usado em pequenas quantidades), impermeabilizantes, pigmentos (se for utilizado um agregado colorido, não há necessidade da colocação de pigmentos) e cinzas volantes.

Os fatores que influenciam no desempenho de uma argamassa de cal são: matéria-prima utilizada, tipo de forno, temperatura e tempo de reação, método de hidratação, método e tempo de armazenamento, agregados, aditivos, técnicas de mistura, método de aplicação, condições durante e após aplicação, tudo isso associado à experiência do profissional.

A carbonatação não ocorrerá nem em umidade muito alta, nem muito baixa, sendo otimizada em condições oscilando entre 40 a $90 \%$ de umidade. Entre 20 a $40 \%$, a carbonatação é restrita. 
Quanto mais velha a cal, melhor a sua qualidade, já diziam Vitruvius e Alberti. Um teste para saber o nível de carbonatação da cal é feito com a utilização da fenolftaleína. Quando em contato com cal carbonatada ela fica incolor. Quando em contato com hidróxido de cálcio, ou seja, cal não carbonatada e por isso fortemente básica, ela fica rosa.

A durabilidade de uma argamassa está ligada ao processo de execução, onde a técnica de execução de multicamadas é muito eficiente. Esta técnica é usada desde a Antiguidade, consistindo da aplicação de várias camadas de pouca espessura e com diminuição da granulometria dos agregados em direção às camadas mais exteriores. Na primeira camada, com agregados mais grossos, era adicionado cocciopesto ou pó de tijolo (opus signinum). Sobre esta aplicavam-se mais duas camadas de argamassa de cal e areia (opus arenatum), finalizando-se com até três finas camadas com pasta de cal e pó de mármore (opus marmoratum). Porém, esta sequência completa de execução nem sempre era aplicada, conforme ressaltado por Veiga et al. (2004).

A função primordial destas multicamadas é manter uma elevada permeabilidade ao vapor de água e ser resistente à entrada de água.

Veiga et al. (op. cit.) também descrevem a metodologia usada no LNEC para caracterização das argamassas antigas, e que é descrita sucintamente a seguir.

A identificação de camadas é feita pela análise estratigráfica in situ ou em laboratório com lupa ou microscópio petrográfico.

Na determinação da composição da argamassa são usadas as seguintes técnicas: análise química por via úmida (ataque ácido, e eventualmente espectrofotometria de absorção atômica, espectrofotometria de emissão de plasma-ICP, e cromatografia iônica) para identificar a fração solúvel em água e o resíduo insolúvel em ácido, microscopia óptica para análise microestrutural, difração de raios $X$ para identificação da natureza dos constituintes, análises termogravimétricas e termodiferenciais para analisar o teor de cal, microscopia eletrônica de varredura para caracterizar a morfologia dos constituintes e espectrofotometria de infravermelho por transformada de Fourier (FTIR) para identificar a natureza dos compostos orgânicos presentes.

Soma-se a estas técnicas o uso de microscópio USB (Figura 6.7), sendo muito prático e funcional para a realização de análises in situ.

Para determinar se a substituição de uma argamassa pode vir a manchar a pedra na qual ela se assentará, Schaffer (1931) propôs um teste muito simples, mostrado na Figura 6.8, que é mais indicado no caso de se utilizar uma argamassa hidráulica.

Para o caso de ser necessária a substituição total ou parcial de uma argamassa antiga, a nova deve atender os seguintes requisitos: não contribuir para degradar os elementos préexistentes, proteger as paredes, não prejudicar a apresentação visual da arquitetura e ser durável (Veiga 2003). E, em todos os casos, também devem ser observados os requisitos ligados à ética da conservação, tais como: reversibilidade, reparabilidade, e identidade funcional, material e tecnológica (Veiga et al. op. cit.). Estes autores relacionam os ensaios a serem realizados para avaliar o cumprimento destes requisitos. 
Tavares (2011) propõe uma metodologia para a restauração de revestimentos exteriores de edifícios antigos a partir da utilização de técnicas analíticas e seleção de produtos mais apropriados a serem utilizados.

Ashurst (1990) indica os procedimentos corretos e incorretos para serem seguidos no tratamento de juntas.

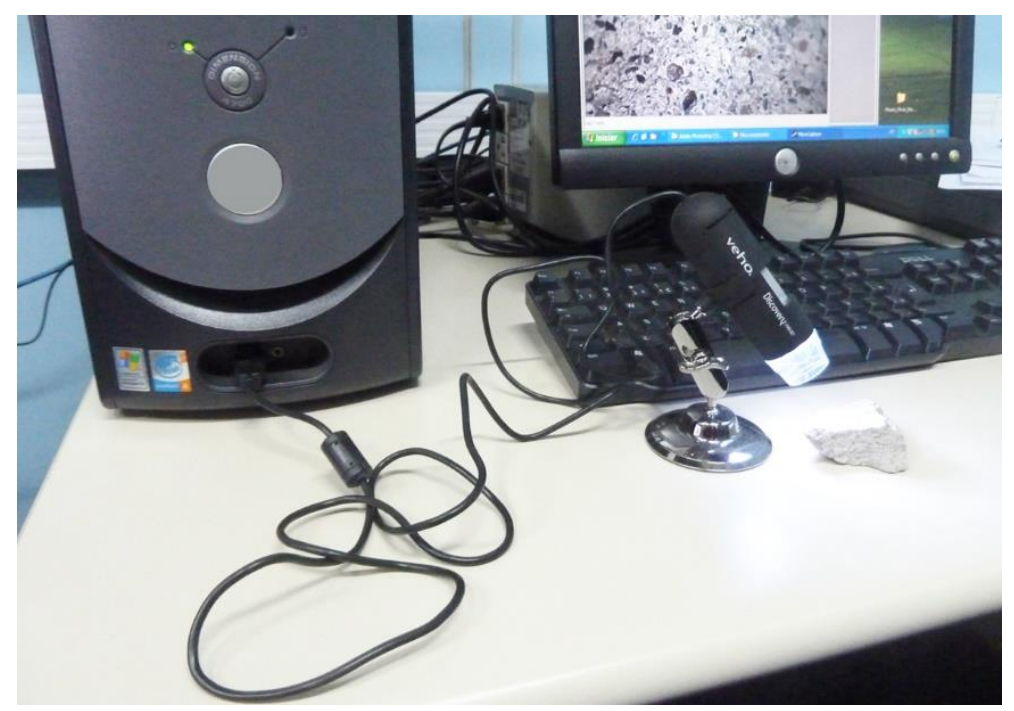

Figura 6.7. Microscópio USB, adequado para visualizações in situ.

ITEMS REQUIRED FOR
THE TEST
Mortar cubes $50 \mathrm{~mm} \times 50 \mathrm{~mm}$
(one for each possible mix)
Stone cubes $50 \mathrm{~mm} \times 50 \mathrm{~mm}$
(one for each mortar cube)
Clean blotting paper squares
each $50 \mathrm{~mm} \times 50 \mathrm{~mm}$
Glass dish, lid etc. to
contain $1 \mathrm{~cm}$ water

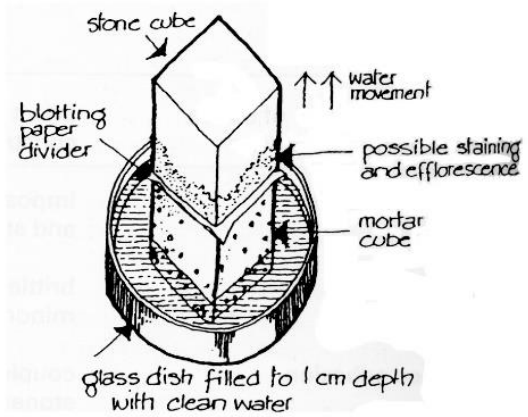

Figura 6.8. Teste para determinar se a argamassa manchará a pedra. Adaptado de Ashurst (2002).

\subsection{Sais}

A cristalização de sais é um processo que degrada tanto a argamassa quanto a pedra, atacando materiais porosos independente da composição química, particularmente nas zonas costeiras e áreas desérticas, mas que ocorrem em todo e qualquer tipo de ambiente. 
É muito comum ocorrer na parte inferior das edificações (Figura 6.9) onde é maior a umidade.
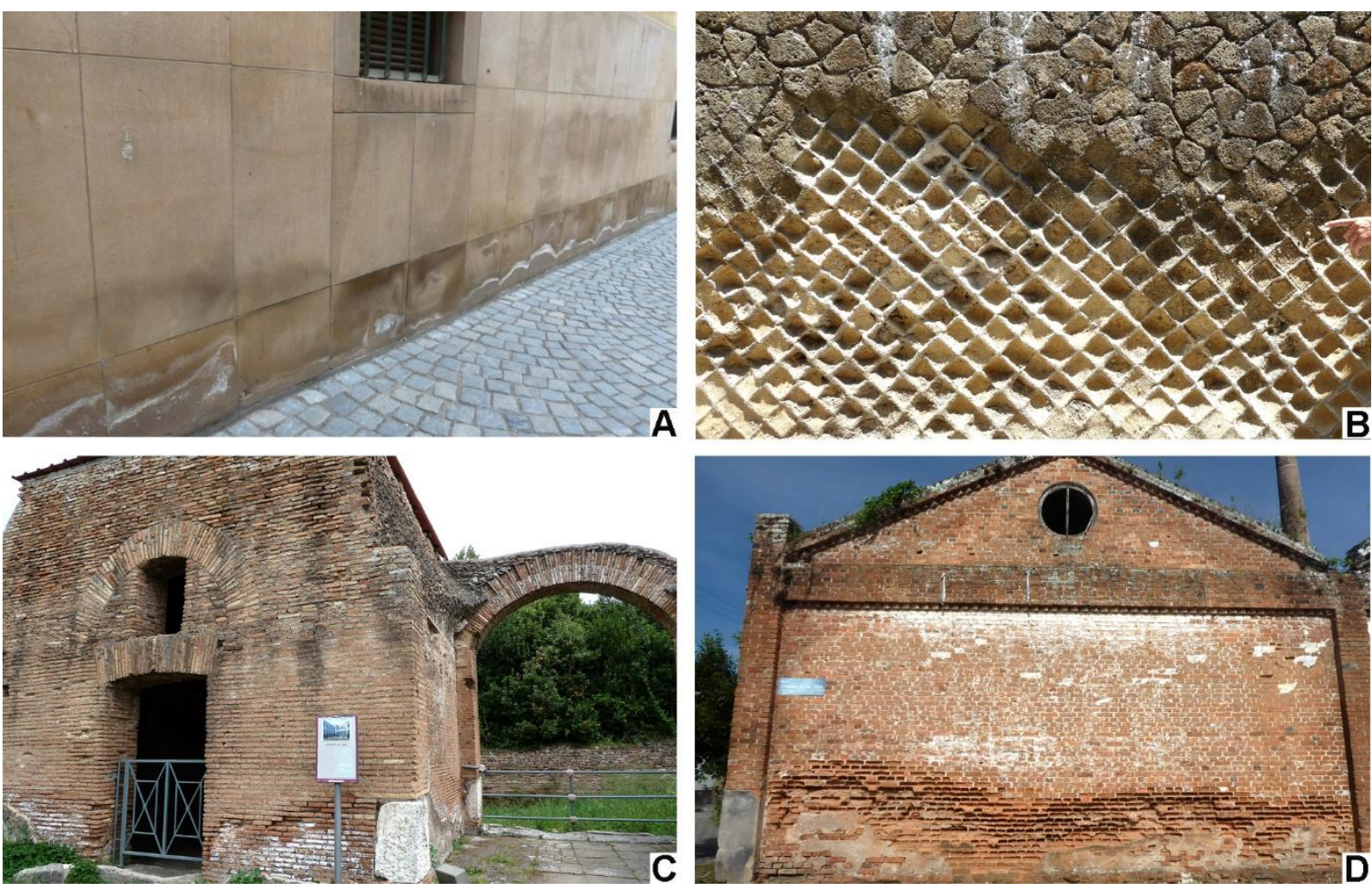

Figura 6.9. Ocorrência de cristalização de sais na parte inferior da edificação, seja em pedra (A e B) ou tijolo (C e D). A. Praga, República Tcheca. B. Sítio Arqueológico de Herculano, Itália. C. Ostia Antica, Itália. D. Iguape, São Paulo.

Delgado Rodrigues \& Gonçalves (2006) discutem o efeito danoso dos sais nas construções históricas, seus mecanismos de atuação e formas de remediação. Os autores apresentam em suas referências bibliográficas uma série de trabalhos que também tratam da cristalização de sais.

O problema com os sais começa quando uma solução salina se aloja nos poros ou nas fissuras da rocha. Em condições de baixa umidade, a água evapora e o sal cristaliza na superfície da alvenaria ou dentro dos poros, ocorrendo eflorescência ou criptoeflorescência, respectivamente. Ou pode acontecer que ocorram ambas as formas. Variações de temperatura também auxiliam neste processo. $O$ ataque dos sais e a porosidade são proporcionais, entretanto para poros grandes o dano é menor.

A ocorrência da eflorescência é antiestética mas pode não ser exatamente um grande perigo, diferentemente da criptoeflorescência que, neste caso, vai pressionar as paredes dos poros ou das fissuras da rocha, potencializando os riscos do fissuramento. Esta pressão exercida pelo crescimento interno do cristal é o principal dano causado por sais, e esse dano vai depender do tipo de sal e do tamanho dos poros.

As fontes de sais são diversas, tais como: sais autóctonos (da própria rocha ou da argamassa), sais dissolvidos na água subterrânea, fontes biogênicas, materiais de 
construção e de conservação, poluentes atmosféricos, aerossóis marinhos e sal para derretimento de gelo que pode ser o caso em países de clima frio.

Os principais grupos de sais são: sulfatos, cloretos, carbonatos e nitratos. Os sulfatos são encontrados em materiais de construção modernos e em poluentes atmosféricos. Os cloretos são encontrados nos aerossóis marinhos, nos sais para degelo e na água subterrânea. Os carbonatos são encontrados na água subterrânea, em materiais de construção e em poluentes atmosféricos. Os nitratos são encontrados na água subterrânea, em fertilizantes e em poluentes atmosféricos.

Uma forma de remediação para o problema com os sais pode ser a redistribuição ou remoção dos sais (dessalinização), a conversão química dos sais para outros compostos (por exemplo, o tratamento com carbonato de bário) ou a introdução dos inibidores de sais (a eficácia desta forma de tratamento ainda não foi comprovada).

As tentativas para controlar a migração das soluções salinas incluem a introdução de barreiras, como por exemplo na cidade de Veneza (Figura 6.10); modificação das propriedades hídricas do material, como o uso de microemulsões silicônicas no Palácio Dolmabahçe em Istambul; e ventilação interna da parede com tubos de Knappen (Delgado Rodrigues \& Gonçalves 2006).
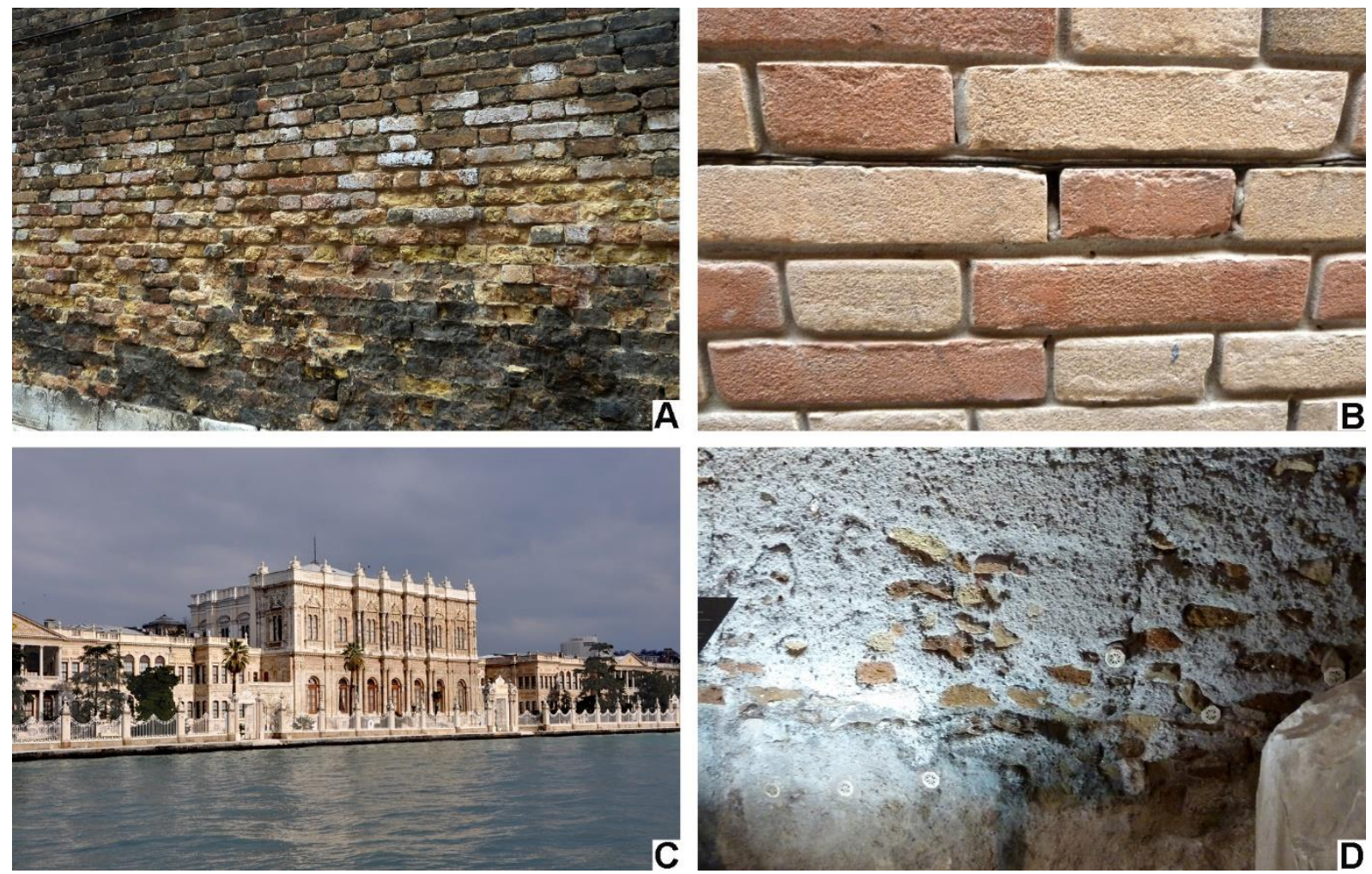

Figura 6.10. Controle de migração de sais. A. Exemplo de degradação de sais solúveis. Observar que os sais concentram-se em uma faixa na parte inferior da construção, Veneza. B. Introdução de barreira impermeável, Veneza. C. Uso de microemulsões silicônicas no Palácio Dolmabahçe, Istambul. D. Tubos de Knappen no Museu Capitolino, Roma. 
No caso de paredes, a argamassa pode ser usada para reter os sais. Delgado Rodrigues (2006) explica o funcionamento de argamassas com diferentes propriedades:

- De transporte rápido - são argamassas que permitem a secagem e o transporte fácil das soluções para a superfície, onde os sais acabam por se depositar (argamassa de cal);

- De transporte lento - são argamassas de funcionamento semelhante ao anterior, mas com uma velocidade de transporte significativamente inferior (argamassa de cimento);

- Acumuladoras de sais - são argamassas que deixam secar as paredes, de forma que os sais se depositem no interior dessa mesma argamassa;

- Bloqueadoras de sais - são argamassas que permitem a secagem das alvenarias, mas que forçam os sais a permanecer no interior da parede;

- Selantes - são argamassas que não permitem a secagem, pelo que forçam a água e os sais a permanecerem no interior das paredes.

No caso de uma argamassa de transporte rápido, a absorção de água por capilaridade é elevada, ao contrário do que ocorre para uma argamassa de transporte lento. Argamassa acumuladora de sais possui dupla camada, sendo a exterior hidrófuga. Argamassa bloqueadora de sais pode ter uma única camada, e neste caso hidrófuga, e elevada permeabilidade ao vapor de água. Argamassa selante é impermeável à água e ao vapor, sendo um sistema muito arriscado (Delgado Rodrigues op. cit.).

Para cada tipo de sal existe uma umidade relativa de equilíbrio. Desta forma, bastaria fazer a identificação do sal e assim controlar-se a umidade, o que favoreceria a não ocorrência do problema derivado da presença dos sais.

A real complexidade reside no fato que normalmente um tipo de sal nunca ocorre sozinho, há sempre outros sais presentes. Em não se conhecendo a composição exata da solução salina, muito menos as proporções nas quais os sais estão presentes, não é possível evitar a supersaturação da solução, e nem o comportamento destes sais.

Exemplos de cristalização de sais em construções históricas brasileiras são apresentados por Loureiro et al. (2015) na Igreja de Santo Alexandre em Belém e por Ricardo (2015) no Paço Imperial do Rio de Janeiro.

\subsection{Afrescos}

A argamassa de cal também é usada em técnicas pictóricas mais complexas como por exemplo os afrescos (Figura 6.11).

Pintura em afresco é a pintura executada com pigmentos destemperados com água pura sobre uma argamassa ainda fresca. O processo do afresco usufrui da propriedade da cal de formar - com a areia, a água e as cores - uma estrutura resistente e impermeável após a secagem, qualidades distintivas do buon fresco.

Por meio de um estudo de caso, serão abordadas as técnicas mineralógico-texturais para a caracterização de pinturas murais, em particular dos afrescos de Fulvio Pennacchi na Capela do Hospital das Clínicas, na cidade de São Paulo. 

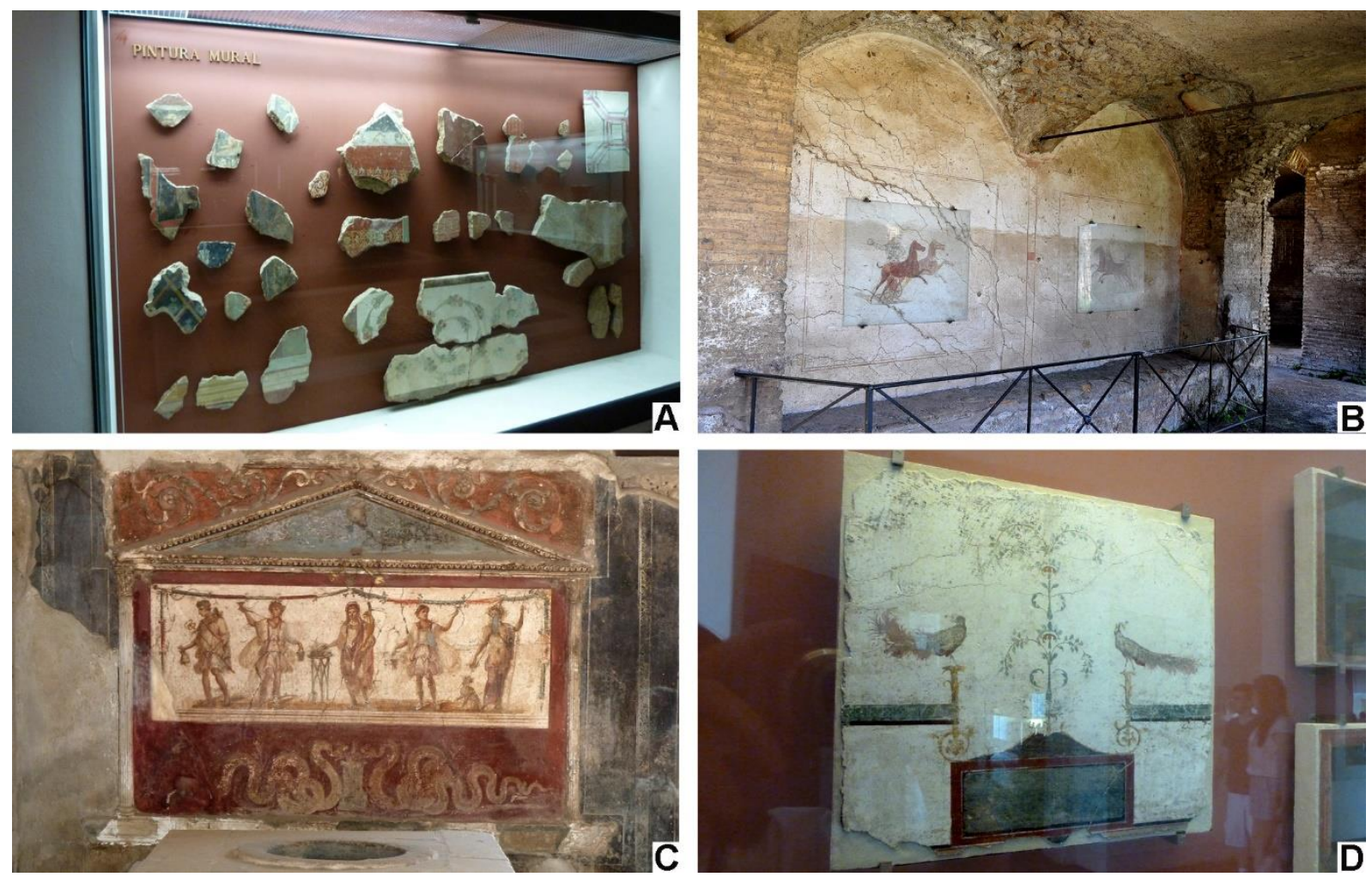

Figura 6.11. Pinturas murais antigas. A. Sítio Arqueológico de Conimbriga, Portugal. B. Ostia Antica, Itália. C. Pompeia, Itália. D. Afresco de Pompeia exposto no Museu Nacional, Rio de Janeiro. Este e mais 3 afrescos também lá expostos fazem parte da Coleção Teresa Cristina, enviada ao Rio de Janeiro em 1855.

Este estudo foi efetuado em projeto conjunto com o Centro de Preservação Cultural (CPC), órgão ligado à Pró-Reitoria de Cultura e Extensão Universitária da USP.

A escolha por Fulvio Pennacchi justifica-se pela grande importância que ele teve para a história da arte em São Paulo. Nascido na Toscana, Itália, em 1905, morreu em São Paulo em 1992, tendo vindo para o Brasil em 1929. Participou do Grupo Santa Helena, uma associação de classe dedicada à investigação e desenvolvimento de técnicas artísticas, na década de 30 .

A técnica de pintura em afresco não fez parte de sua formação, tendo-a desenvolvido de maneira própria após algumas experiências.

As obras estudadas situam-se no último pavimento (11aar andar) do bloco central do edifício principal do Hospital das Clínicas, hoje identificado como Instituto Central. Pennacchi executou dois afrescos na parede do altar: Anunciação da Virgem $(232 \times 265 \mathrm{~cm})$ e Ceia de Emaús $(237 \times 245 \mathrm{~cm}$ ) (Figura 6.12). Estas obras foram tombadas pelo Condephaat (Processo 9079/69) e pelo Conpresp (Processo 16-001.857-91*00) e podem ser visualizadas no livro Bens imóveis tombados ou em processo de tombamento da USP (CPC 2002).

As técnicas analíticas utilizadas neste estudo foram: microscopia petrográfica, microscopia eletrônica de varredura com EDS, difração de raios $X$, microssonda eletrônica e obtenção de imagens por radiação ultravioleta. 

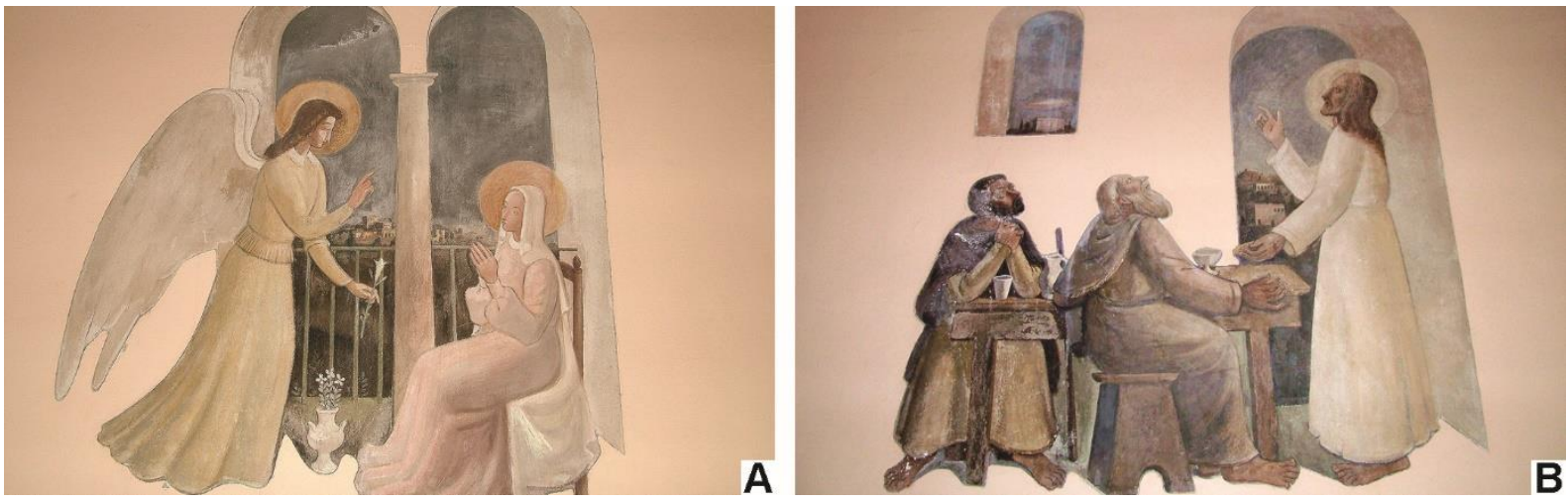

Figura 6.12. Afrescos de Fulvio Pennacchi na capela do Hospital das Clínicas, São Paulo. A. Anunciação da Virgem. B. Ceia de Emaús.

Para a análise do material da pintura mural com utilização destas técnicas, foram retirados pequenos fragmentos da camada pictórica, priorizando sempre a integridade da obra, com o menor dano possível. As informações a respeito da espessura das camadas existentes foram obtidas a partir de cortes estratigráficos das amostras.

A utilização conjunta destas técnicas tornou possível a identificação dos componentes da argamassa e suas respectivas proporções, além de informações a respeito da granulação, impurezas minerais presentes e características texturais dos minerais; identificação dos pigmentos utilizados pelo pintor; e caracterização de feições de deterioração e estudo de cristalização dos sais.

\subsubsection{Estado geral das obras do Hospital das Clínicas}

Das duas pinturas murais na capela do Hospital das Clínicas, a Anunciação da Virgem encontra-se em estado razoável de conservação, apresentando apenas eflorescência na parte superior sobre a superfície da parte pintada. A outra obra, Ceia de Emaús, apresenta criptoeflorescência concentrada entre o estrato pictórico e a camada subjacente, o que provoca maior dano ao afresco, conferindo-lhe o aspecto pulverulento e caracterizando um avançado estado de deterioração (Figura 6.13).
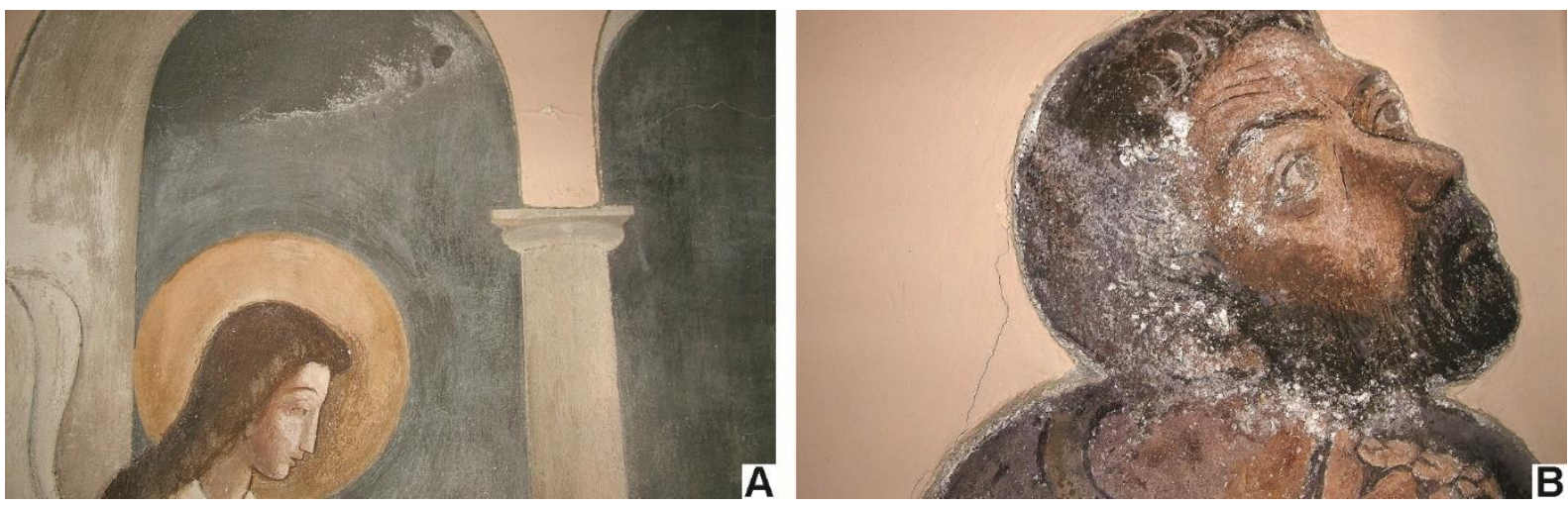

Figura 6.13. Eflorescências nos afrescos de Fulvio Pennacchi na capela do Hospital das Clínicas, São Paulo. A. Anunciação da Virgem. B. Ceia de Emaús. 
A eflorescência é observada não só nos afrescos, como também na própria parede lisa da capela, próximo à obra Anunciação da Virgem.

Estes sais solúveis identificados, especificamente $\left(\mathrm{SO}_{3}\right)^{-2}$, poderiam ser oriundos de uma das três situações:

(1) da argamassa de assentamento da alvenaria de tijolos;

(2) da argamassa do revestimento dos tijolos, suporte da pintura;

(3) do gesso adicionado aos pigmentos para aplicação da cor.

As análises para caracterização das argamassas mostram um teor de $\mathrm{SO}_{3}$ muito baixo, o que pode ser indicativo de que $\mathrm{O}_{\mathrm{SO}_{3}}$ seja proveniente do próprio afresco. Mas os sais identificados (epsomita e gipsita) estão presentes também nas partes sãs dos afrescos, sendo os constituintes principais da eflorescência. $O$ aparecimento da eflorescência está ligado às trincas observadas na parede externa da capela, cujo revestimento de fouget está desgastado e consequentemente mais permeável, constituindo-se num caminho para a migração da umidade para dentro da capela, que solubiliza o sulfato da camada pictórica do afresco.

Na obra Ceia de Emaús notam-se também outras alterações, principalmente nas partes pigmentadas em preto e marrom. Nestas, observa-se biodeterioração, que pode estar relacionada a materiais utilizados em antigos restauros, incompatíveis com a obra original (Del Lama et al. 2006) (Figura 6.14).

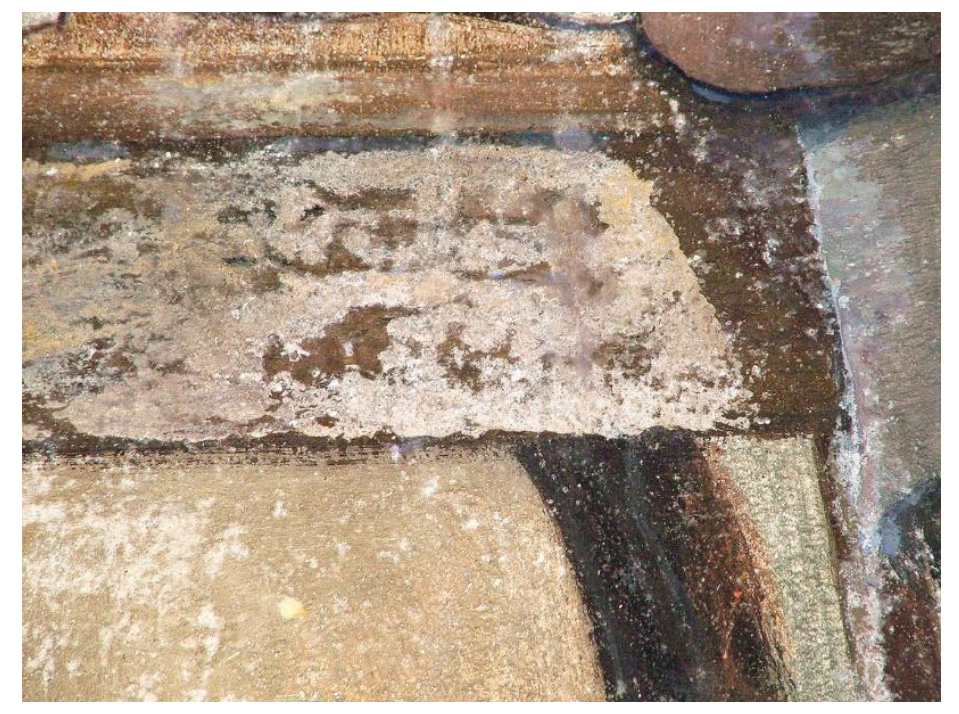

Figura 6.14. Afresco Ceia de Emaús. Porção bastante degradada com aspecto aveludado e pulverulento.

Por questões construtivas do Hospital das Clínicas, existe um vão entre a parede externa do edifício e parte do suporte do afresco. Justamente onde há o vazio do vão, o afresco não apresenta nenhum sinal de umidade, tendo esta parte do afresco sido protegida não só da umidade oriunda do exterior como das flutuações de temperatura, funcionando como um 
isolante, não se observando aí ocorrência de deteriorações nem de eflorescências (Figura 6.15).
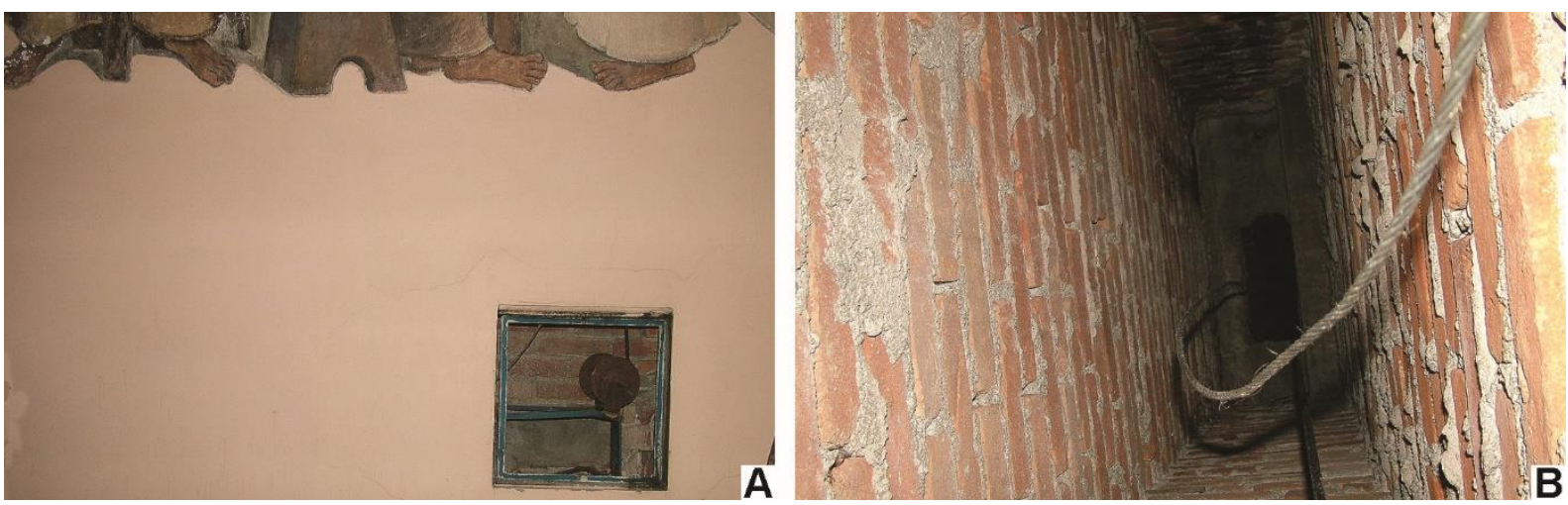

Figura 6.15. Causas da não existência de deterioração em parte do afresco Ceia de Emaús: presença de um vão entre o suporte da pintura e a parede externa. A. Visão frontal. B. Visão dentro do vão.

Nos afrescos também foram observadas algumas anomalias associadas à sua não adequada conservação e manutenção, como por exemplo:

- marcas de escorrimento de água, principalmente na janela à esquerda da obra Ceia de Emaús;

- rachaduras que foram restauradas, que provoca anomalia na pintura sob a incidência de luz ultravioleta;

- respingo de tinta de coloração rosa na obra Anunciação da Virgem, proveniente da pintura atual da capela.

\subsubsection{Resultados}

Del Lama et al. (2009) descrevem que nos afrescos do Hospital das Clínicas, Pennacchi utilizou não só a técnica do afresco, como também a técnica mista chamada mezzo fresco. Esta técnica consiste em deixar a argamassa secar até que esteja firme antes de executar a pintura. Para garantir melhor penetração na superfície semisseca, os pigmentos são misturados em água de cal para melhor aderência (Mayer 2002). Em alguns trechos foi usada "pintura a seco", uma vez que foi retirado um strapo com a película pictórica, sem a presença da massa subjacente.

Observou-se uma argamassa razoavelmente compactada, com aglomerante bem cristalizado e presença de fibras e microfissuras. Algumas porções são bastante porosas, pulverulentas e com presença de sais solúveis. É composta principalmente de calcita, dolomita, quartzo, microclínio e muscovita.

A princípio, a mica não deveria estar presente nos agregados, já que pode reduzir a aderência do revestimento à base, mas foi usada por Pennacchi, propositadamente, para 
conferir brilho e fulgor à obra. Esta técnica também foi utilizada por outros afresquistas, como por exemplo o pintor brasileiro Carlos Magano na obra $A$ marcha do conhecimento humano, que se encontra no saguão da Faculdade de Educação da USP (Goulart 2001).

Pennacchi usou armações de celotex nestas pinturas murais, um composto fibroso, onde aplicava um reboco forte (Bardi 1980). A literatura denomina estas fibras minerais orgânicas e inorgânicas de celotex, podendo ser constituídas por bagaço de cana-de-açúcar ou serragem. Não há dúvidas da presença de fibras nas argamassas utilizadas pelo pintor, inclusive em outras obras, mas não há muitos registros ou análises destas fibras. As análises aqui efetuadas, sem excluir outras hipóteses, apontam que as fibras identificadas nas pinturas murais da capela do Hospital das Clínicas podem ser provenientes de bagaço de cana-de-açúcar. O diâmetro das fibras utilizadas varia de 0,5 a $2 \mu \mathrm{m}$ (Figura 6.16).
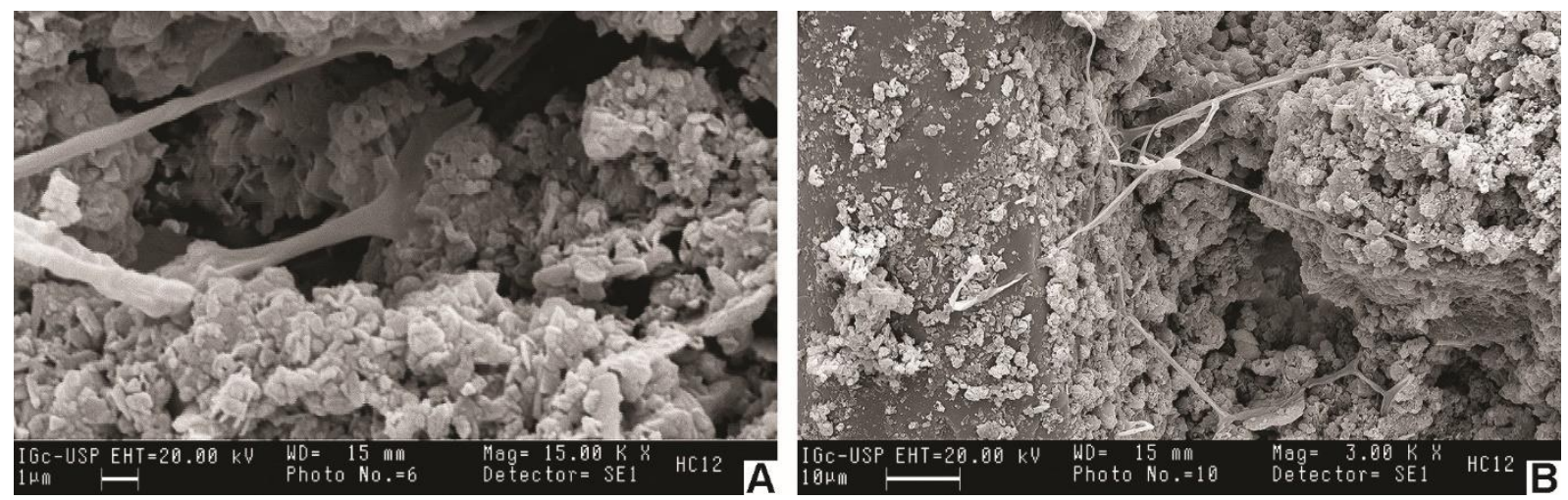

Figura 6.16. A e B. Imagens de elétrons secundários obtidas em microscópio eletrônico de varredura indicando a presença de material fibroso na argamassa.

Na camada pictórica predomina a presença do carbonato de cálcio, tendo aproximadamente de 200 a $700 \mu \mathrm{m}$, constituindo-se numa superfície bastante irregular.

A cal da argamassa está totalmente carbonatada, atestado pela ausência dos picos de $\mathrm{CaO}$ e $\mathrm{Ca}(\mathrm{OH})_{2}$ nas análises de DRX.

Estes afrescos apresentam no máximo duas camadas, sendo que o número de camadas está associado à textura pretendida por Pennacchi. Quando se utiliza apenas uma camada, a textura apresenta aspecto bastante granuloso e com agregados visíveis, e neste caso, a cor espalha-se nos interstícios dos grãos, sem formar camada aparente.

Quando se têm duas camadas, a textura constitui um material colorido espesso, encobrindo os agregados da argamassa subjacente. Em algumas partes nesta textura aparecem superfícies bem lisas, com aplicação de "massa e/ou tinta" homogênea.

O principal aditivo usado por Pennacchi em seus afrescos foi o gesso, utilizado para dar uma textura diferenciada em algumas partes da obra, como observada na segunda textura, nas superfícies mais lisas.

O pigmento identificado mais abundante nas pinturas murais analisadas é a barita (sulfato de bário), seguido pelo ferro e em menor quantidade o chumbo. 
Uma característica técnica na obra de Fulvio Pennacchi é a presença de pequenos pontos azuis a violetas, harmonizando a cor em alguns trechos dos afrescos.

Com relação ao estado de conservação das duas obras, a Anunciação da Virgem pode-se considerar que ela tem estado razoável de conservação, apresentando apenas eflorescência na parte superior. A outra obra, Ceia de Emaús, está bastante danificada e com aspecto pulverulento devido à presença de eflorescência de sais, com a desagregação da superfície colorizada da massa, deixando à vista o reboco subjacente.

A eflorescência observada no afresco Anunciação da Virgem causa um dano estético à obra, mas no afresco Ceia de Emaús a sua presença está comprometendo a integridade da obra.

A pesquisa sobre os afrescos de Fulvio Pennacchi continua com o estudo do afresco Alegoria ao Desenvolvimento Industrial Paulista (Magon 2015).

\section{REFERÊNCIAS}

Ashurst J. 1990. Mortars for stone buildings. In: J. Ashurst, F.G. Dimes (eds.). Conservation of building \& decorative stone. Grã-Bretanha, Butterworth Heinemann, Part 2:78-96.

Ashurst J. 2002. Mortars, Plasters and Renders in Conservation. London, Ecclesiastical Architects' and Surveyors' Association, 108 p.

Bardi P.M. 1980. Fulvio Pennacchi. São Paulo, Raízes, 185 p.

CPC - Comissão de Patrimônio Cultural. 2002. Bens imóveis tombados ou em processo de tombamento da USP. M.C.F. Lourenço (org.) Conservação e Restauro I. São Paulo: Edusp: Imprensa Oficial do Estado de São Paulo. 224 p.

Del Lama E.A., Shirakawa M.A., Gaylarde C.C., Tirello R.A. 2006. Deterioração de patrimônio histórico - afresco de Fulvio Pennacchi. In: XLIII Congresso Brasileiro de Geologia, Anais, p. 71.

Del Lama E.A., Tirello R.A., Andrade F.R.D. Kihara Y. 2009. Study of mural paintings by Fulvio Pennacchi in São Paulo City by mineralogical techniques. Anais da Academia Brasileira de Ciências, 81(1):115-126. Disponível em: http://www.scielo.br/pdf/aabc/v81n1/a12v81n1.pdf.

Delgado Rodrigues J. 2006. Notas de aula da disciplina GMG5867 - Conservação e Restauração do Patrimônio Histórico Construído. Curso ministrado no Instituto de Geociências da USP.

Delgado Rodrigues J. \& Gonçalves T.D. 2006. Sais solúveis nas construções históricas: introdução e relato sumário. In: Workshop Sais solúveis em argamassas de edifícios antigos - danos, processos e soluções. Lisboa, LNEC, Proceedings, p. 1-13.

Goulart E.P. 2001. Caracterização microestrutural e microquímica da argamassa e dos pigmentos. In: Tirello R.A. (org.) O restauro de um mural moderno na USP: o afresco de Carlos Magano. São Paulo, CPC-PRCEU-USP, p. 154-163. 
Guimarães, J.E.P. 1997. A Cal: Fundamentos e Aplicações na Engenharia Civil. São Paulo, PINI, $285 \mathrm{p}$.

Kanan M.I. 2008. Manual de conservação e intervenção em argamassas e revestimentos à base de cal. Brasília, Iphan/Programa Monumenta, 172 p. (Cadernos Técnicos 8).

Loureiro A.M.S., Angélica R.S., Sanjad T.A.B.C., Oliveira M.M.de, Costa M.L. 2015. Eflorescência salina na igreja de Santo Alexandre, Belém - PA. Ambiente Construído, Porto Alegre, 15(3):71-83.

Magon P.M. 2015. Caracterização material, textural e executiva da pintura mural Alegoria ao Desenvolvimento Industrial Paulista de Fulvio Pennacchi. Dissertação de Mestrado, Instituto de Geociências, Universidade de São Paulo (IGc-USP). (Em andamento)

Mayer R. 2002. Manual do artista. São Paulo, Martins Fontes, 838 p.

Pardal P. 1999. Desfazendo lendas: uma troca de plantas arquiteturais, telhas e coxas de escravas, óleo de baleia nas argamassas. Revista do Instituto Histórico e Geográfico Brasileiro, 160(402):7-29. Disponível em: http://www.ihgb.org.br/images/acervo/rihgb/indices/rihgb-127.pdf.

Ricardo A.M. 2015. Uma rocha e um palácio: características e alterabilidade do Gnaisse Facoidal no Paço Imperial do Rio de Janeiro. Dissertação de Mestrado em Ciências, Instituto de Geociências, Universidade Federal do Rio de Janeiro, Rio de Janeiro, 194 p.

Santiago C.C. 1992. Aditivos orgânicos em argamassas antigas. Dissertação de Mestrado, Faculdade de Arquitetura e Urbanismo, Universidade Federal da Bahia, Salvador, 128 p.

Santiago C.C. 2007. Argamassas tradicionais de cal. Salvador, Editora da UFBA, 202 p.

Souza M.L.de, Del Lama E.A., Oliveira M.C.B.de. 2008. Characterization of historical mortars with gypsum in São Paulo, Brazil. In: HMC08 (Historical Mortars Conference). Lisbon, LNEC, 10 p. CD-Rom.

Tavares M.L. 2011. A conservação e o restauro de revestimentos exteriores de edifícios antigos. Tese de Doutorado, Universidade Técnica de Lisboa, Lisboa, 440 p.

Veiga M.R. 2003. As argamassas na conservação. Lisboa, LNEC, 21 p.

Veiga M.R., Aguiar J., Silva A.S., Carvalho F. 2004. Conservação e renovação de revestimentos de edifícios antigos. Lisboa, LNEC, $126 \mathrm{p}$. 


\section{Tratamentos}

O objetivo na aplicação de um tratamento de superfície deve ser tanto para restaurar quanto para prolongar a vida dos materiais, observando o conceito de mínima intervenção e a prevalência da manutenção. Ele deve ser eficaz e não provocar efeitos colaterais prejudiciais.

Os tratamentos mais comuns que podem ser aplicados em superfícies pétreas são aqui agrupados em três tipos principais: limpeza, consolidação e eliminação de biocolonização.

O conceito de tratamento inclui tanto o produto quanto a técnica adequada de sua aplicação.

\subsection{Limpeza}

A manutenção e a limpeza devem sempre ser efetuadas com o objetivo de se preservar a superfície do objeto para manutenção e valorização do bem patrimonial, eliminando as substâncias nocivas da sua superfície. Deve-se atentar aos procedimentos a serem efetuados para não provocar danos estruturais e/ou estéticos nas obras. Por esta razão, é necessário o conhecimento da pedra em estudo para se efetuar um diagnóstico correto e, por consequência, executar intervenção sem que ocorram efeitos colaterais indesejáveis e, principalmente, que essa intervenção seja mínima, visando preservar o valor estético e histórico da obra.

Referencial teórico para esta temática pode ser encontrado em Webster (1992) e Normandin \& Slaton (2005 e 2006). Um código de prática para a limpeza é apresentado em BS 8221-2 (BS 2012).

A sujeira da pedra pode ser oriunda da deposição de sujidade devido à poluição, pichações ou instalação de colonização biológica. Esta última será tratada especificamente no próximo item.

A limpeza da pedra, quando necessária, deve priorizar principalmente a preservação da sua superfície, valorizando assim o conteúdo histórico e estético do monumento.

E preservar a superfície implica também em preservar a pátina porventura existente. A pátina é a marca na matéria da passagem do tempo, e como tal incorpora-se à história do monumento. Como já dizia Brandi: A eliminação da pátina não restaura a aparência original do objeto, apenas as verdadeiras condições do material (Brandi 1963). 
Boito e Ruskin diziam que a limpeza deveria ser evitada, pois destruíam as manchas e as cores produzidas pelo tempo. Entretanto, com procedimentos de limpeza e tratamento aplicados corretamente, as marcas da passagem do tempo podem ser preservadas.

O conceito de limpeza em obras do patrimônio é controverso, sendo que os argumentos favoráveis à limpeza são que a sujidade provoca danos na pedra, perturba a leitura do objeto e é uma oportunidade para melhor conhecer o objeto. Por outro lado, os argumentos contrários à limpeza são a ocorrência dos frequentes efeitos colaterais nocivos, efeitos estéticos desagradáveis e principalmente o rápido retorno da sujidade.

A limpeza pode ser necessária porque outras intervenções o exigem, como tratamento de juntas ou consolidação, e uma vez definida que é necessário realizar a limpeza, o passo seguinte é definir quanto de limpeza é necessária e suficiente.

Normandin \& Slaton (2006) propõem uma abordagem para um projeto de limpeza de fachadas: observações e análises de laboratório, seleção de uma técnica apropriada, realização de teste em pequena escala, avaliação da limpeza, realização de teste em escala maior, reavaliação da limpeza. No caso do resultado do teste ser satisfatório, proceder com a limpeza.

Uma avaliação pré-limpeza inclui: determinação do tipo de rocha, identificação de tratamentos prévios, realização de medidas de permeabilidade e identificação dos componentes da sujeira.

Os tipos de sujeira são classificados como detritos (poeira, poluentes atmosféricos, excremento de pássaros, folhas), aplicações de superfície (tintas, vernizes, ceras), manchas subsuperficiais (fogo, metal, óleo), manchas relacionadas aos componentes do substrato (exposição de minerais ferrosos a ácidos) e combinação desses fatores.

O método de limpeza a ser selecionado e utilizado deve ser o menos invasivo possível para alcançar os objetivos, considerando os parâmetros de custo, acesso e disponibilidade, e essa seleção deve ser feita somente após a realização de testes acima sugeridos.

As técnicas de limpeza estão continuamente sendo refinadas e melhorados para oferecer métodos ambientalmente sustentáveis mais efetivos e com menos potencial de prejuízo para o substrato. Vale lembrar que cada operação de limpeza tem um efeito direto no substrato.

Revez \& Delgado Rodrigues (2016) propõem um roteiro para auxiliar na escolha do método de limpeza, objetivando diminuir a subjetividade desta decisão, com base no risco envolvido (vulnerabilidade do substrato, agressividade do método de limpeza, sinergia e impacto da importância da superfície a ser limpa) e nos componentes de qualidade.

Os sistemas de limpeza atuais incluem: técnica de limpeza com uso de água, técnica de limpeza mecânica, técnica de limpeza com utilização de radiação, técnica de limpeza química e outras técnicas. Na prática, muitas vezes ocorre a utilização combinada de mais de um destes métodos para maior eficácia da limpeza (Figura 7.1). 

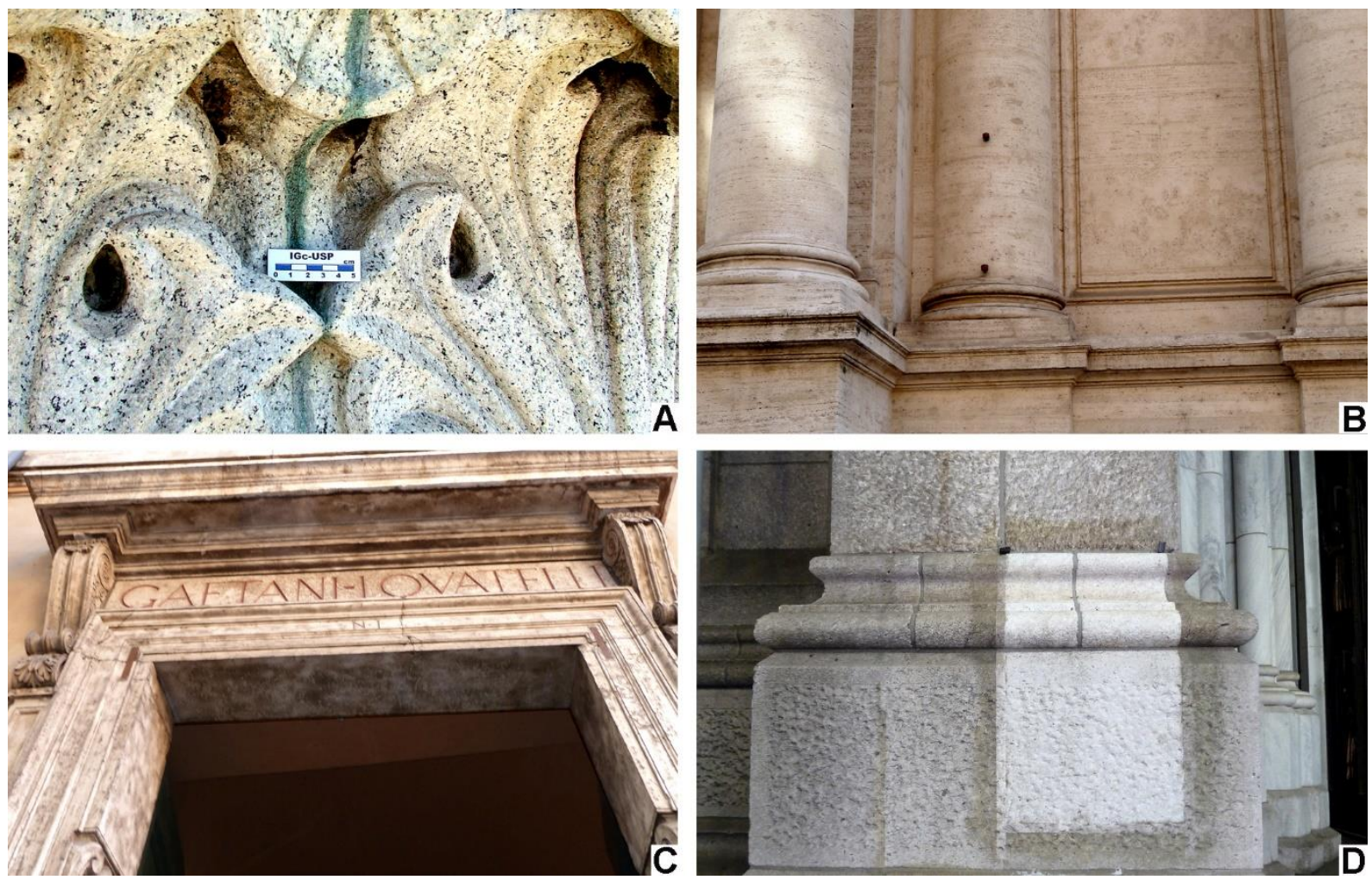

Figura 7.1. Exemplos de limpeza. A. Uma única técnica de limpeza utilizada não foi suficiente para remover a sujidade das reentrâncias, Monumento do Ipiranga, São Paulo. B. Fachada de travertino manchada pelo método de limpeza utilizado, Roma, Itália. C. Uso de jato de areia, danificando ainda mais o substrato, Roma, Itália. D. Teste de limpeza, Catedral de St Patrick, Nova York.

\subsubsection{Técnica de limpeza com água}

A técnica com água pode ser dar com utilização de esponjas e escovas (Figura 7.2A), utilização de spray ou pulverizador (Figura 7.2B), lavagem com pressão (Figuras 7.2C e D), lavagem com pulsos intermitentes, lavagem a vapor e compressas (poultices). Na utilização de qualquer destes métodos deve-se fazer a proteção das áreas vizinhas.

Porém, mesmo não fazendo uso de produtos químicos nesta técnica, a operação de limpeza pode provocar manchamento na superfície, como por exemplo se a água estiver contendo ferro.

Nunca se deve fazer lavagem com utilização de escova de aço, pois além de ser erosiva, há o risco de deixar fragmentos de aço no edifício, que posteriormente poderá provocar a formação de pequenas manchas de ferrugem.

A lavagem com pressão só deveria ser usada em pedras que apresentem sujidade mas que estejam em boas condições, e que não sejam susceptíveis à entrada de água. Pode ser usada previamente a limpeza química para apenas umedecer a alvenaria com água, e posteriormente na etapa final para fazer o enxague pós limpeza. A pressão utilizada vai depender do substrato, e este é o fator mais importante deste sistema. Também influenciam o volume de água, o diâmetro ou abertura da mangueira ou do pulverizador, e a distância da mangueira ao objeto. 
A limpeza a vapor é uma alternativa que usa menos água. Este método não foi usado durante muito tempo devido ao risco de sua utilização para os trabalhadores, mas atualmente os equipamentos apresentam maior segurança no seu manuseio. É usada principalmente para a remoção de goma de mascar, depósitos de gordura ou piche e giz de cera. O principal problema na utilização desta técnica é a possibilidade de infiltração de água em fissuras e/ou nos materiais porosos. Nestes casos, deve-ser considerar a utilização de limpeza a seco.
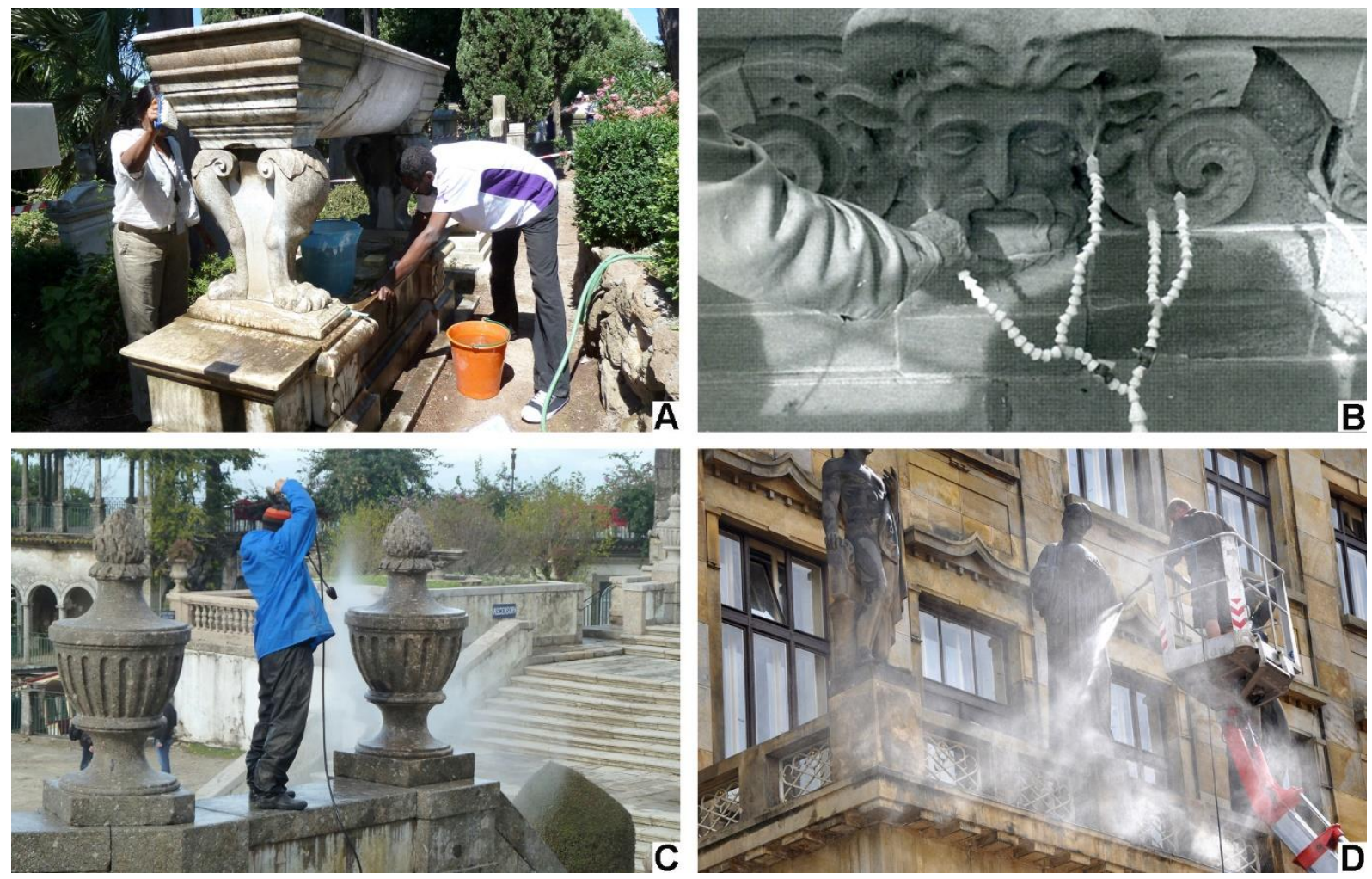

Figura 7.2. Técnica de limpeza com água. A. Utilização de água e escovas, Cemitério Acatólico, Roma, Itália. B. Utilização de pulverizador. Braços articulados permitem acesso a áreas mais escondidas. Fonte: Normandin \& Slaton (2005). C.

Lavagem com pressão, Santuário Bom Jesus do Monte, Braga, Portugal. D. Lavagem com pressão, Praga, República Tcheca.

\subsubsection{Técnica de limpeza mecânica}

A aplicação de técnica de limpeza mecânica pode se dar com escovação a seco, utilização de bisturis e espátulas, e uso de abrasivos.

Ao se optar pelo sistema abrasivo, ter sempre em mente que a sujeira presente em fissuras e fendas não pode ser removida por uma partícula maior que a abertura das fendas, enquanto que a água não tem esta limitação. Este sistema não deve ser usado em superfícies polidas.

Os parâmetros importantes do sistema abrasivo são: tipo de bico, pressão e taxa de fluxo, e tipo de abrasivo a ser utilizado. 
A forma do bico é muito importante: bocais Venturi que dão uma distribuição homogênea são úteis para áreas planas; para limpeza de superfícies com maior número de detalhes, bicos como "lápis" são mais adequados; bicos curvos e angulares também estão disponíveis para atingir locais mais profundos.

A pressão determinará a variação da taxa de fluxo. Como regra geral, em um trabalho de limpeza deve-ser manter a pressão e a quantidade de abrasivos as mais baixas possíveis.

A natureza do abrasivo é importante e deve ter sempre dureza menor que o substrato a ser limpo (Figura 7.3). Partículas arredondadas tendem a ricochetear na superfície e por isso são adequadas para a remoção de depósitos quebradiços (tais como tintas epóxi), especialmente em substratos mais duros. Partículas angulares tendem a cortar e podem ser utilizadas para a remoção de sujeira tanto branda quanto resistente, mas apenas nos casos em que o substrato seja mais duro que a sujidade. Outros tipos de materiais abrasivos, como plásticos, esponjas de poliuretano impregnadas com abrasivos, e gelo seco (dióxido de carbono) estão sendo atualmente investigados para uso em limpeza, mas poucos destes têm sido usado em monumentos.

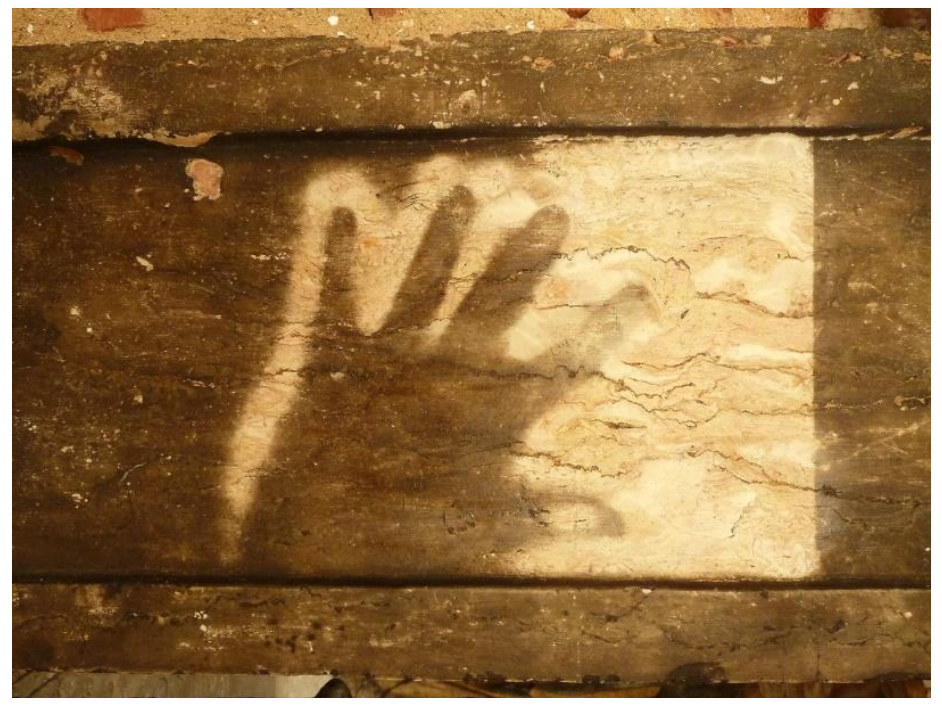

Figura 7.3. Teste de limpeza com abrasivo demonstrando sua baixa abrasividade, Sé de Lisboa, Portugal.

Métodos de limpeza utilizando areia de alta pressão ou jateamento de areia não é (ou não deveria ser) mais usado em construções devido aos danos causados por este método (Figura 7.1C). Em substituição, atualmente é utilizado um sistema microabrasivo, em que se aplica um sistema com baixa pressão e partículas finas (inferior a $90 \mu \mathrm{m}$ ).

O sistema abrasivo também pode ser usado com água, o que diminui um pouco a abrasividade. 


\subsubsection{Técnica de limpeza a laser}

A limpeza com utilização de raios laser (Light Amplification by Stimulated Emission of Radiation) é considerada uma técnica limpa, pois não utiliza água, gera resíduos somente da própria ablação e não utiliza produto químico.

Foi inicialmente usada para limpeza de monumentos e trabalhos de arte, e nas últimas duas décadas tem sido usada também em limpeza de edifícios.

O primeiro uso em conservação foi na década de 1970, quando Asmus desenvolveu um limpador de estátua. Em 1980, a Porta della Carta no Palazzo Ducale em Veneza foi limpa com laser. Em 1995, acontece a primeira conferência LACONA, uma organização internacional, dedicada à pesquisa e desenvolvimento de raios laser para uso em conservação, e desde então repete-se binualmente. A $11^{\underline{a}}$ edição da conferência ocorrerá em setembro de 2016 em Cracóvia, Polônia.

O equipamento compõe-se de fonte de laser, sistema de arrefecimento, braço articulado ou fibra óptica, e disparador, e emite pulsos curtos de radiação de comprimento de onda único: ultravioleta, visível ou infravermelho.

A limpeza é controlada pela energia do pulso, o diâmetro do feixe, o número de pulsos por segundo e a distância de trabalho entre o disparador e a superfície. Dada a finura do ponto de laser, o trabalho de limpeza demanda muito tempo para aparecer o resultado final, particularmente em superfícies com áreas muito grandes. É possível juntar várias fibras no mesmo feixe, aumentando assim o rendimento. Esta técnica foi utilizada na limpeza de todos os arcos das galerias inferiores do Claustro dos Jerónimos em Lisboa (Portugal), o que demandou 2 anos (IPPAR 2006).

A sujidade a ser removida geralmente exibe propriedades de absorção diferentes do substrato subjacente onde ela se instala. A energia do feixe do raio incidente é absorvida pela sujidade e é vaporizada da superfície (é audível como um estalo) por expansão térmica (sujidade típica de carbono absorve cerca de $90 \%$ da radiação laser incidente). O substrato subjacente limpo, principalmente se for de cores claras, reflete a radiação emitida, impedindo danos, sendo daí proveniente o termo limpeza autolimitante para esta técnica de limpeza.

Dentre os fatores adversos para a utilização desta técnica pode ser citada a modificação de cor em partes coloridas do objeto em limpeza, e, como cuidados adicionais, considerar que a exposição à radiação laser pode prejudicar a pele e os olhos, não devendo assim ser incidido diretamente sobre a pele e que devam ser usados óculos de proteção durante seu manuseio.

Exemplos de aplicação da limpeza a laser em monumentos podem ser encontrados em Salimbeni et al. (2000), Sabatini et al. (2000), IPPAR (2006) e Grossi et al. (2007).

Estima-se que hoje existam mais de 300 sistemas de limpeza a laser em utilização mundial para conservação (Figura 7.4). No Brasil o único equipamento disponível está instalado no LACORE da FAU-UFPA (Laboratório de Conservação, Restauração e Reabilitação da Faculdade de Arquitetura e Urbanismo da Universidade Federal do Pará), sob responsabilidade da arquiteta profa. Thais A.B.C. Sanjad. 

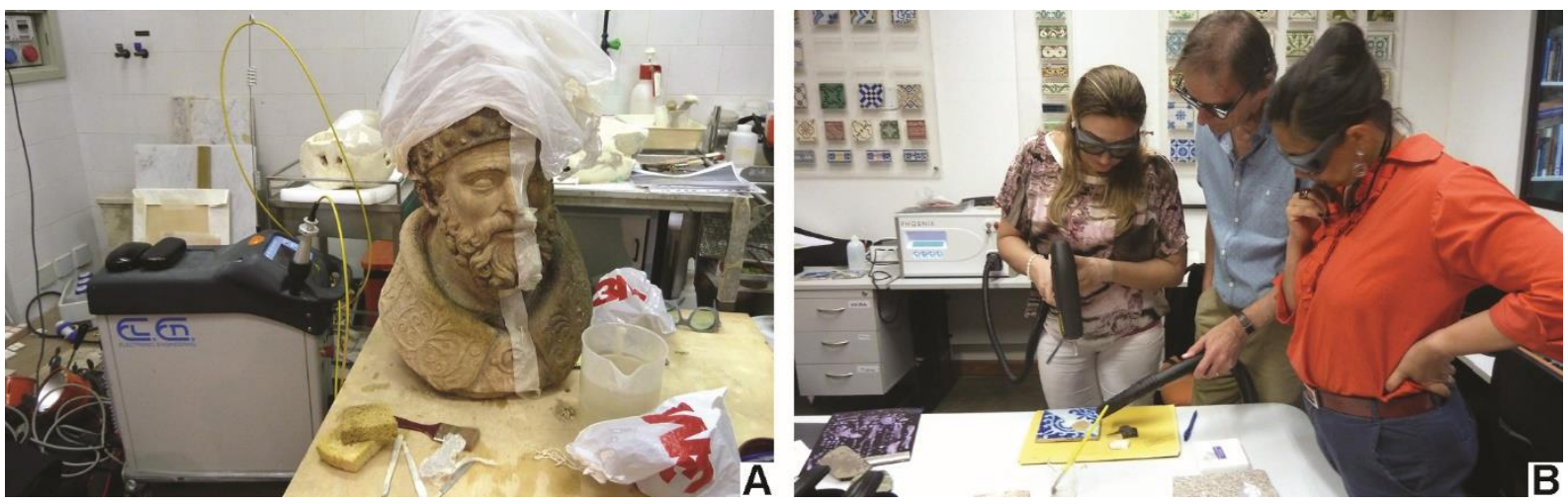

Figura 7.4. Técnica a laser. A. Sistema a laser da Electronic Engineering e exemplo de aplicação na parte esquerda da escultura, Instituto Centrale del Restauro, Roma, Itália. B. Sistema a laser da Lynton, modelo Phoenix, exemplo de aplicação em azulejo, LACORE, Belém, Pará.

\subsubsection{Técnica de limpeza química}

Os compostos utilizados no método de limpeza química podem ser ácidos, alcalinos, solventes orgânicos ou agentes quelantes. Esses produtos reagem com as camadas sujas ou mesmo com o próprio substrato para dissolver ou remover as sujeiras e manchas.

Ao usar qualquer método químico, é muito importante considerar a preparação da superfície, a aplicação, a remoção e o enxague, e sempre seguir rigorosamente todos os procedimentos e normas de aplicação e segurança, pois alguns produtos são perigosos para os seres vivos e para o ambiente.

Outros fatores a considerar são a diluição e o período que o produto pode permanecer atuando nas superfícies a serem tratadas (dwell time), tempo este recomendado pelos fabricantes e varia de menos de 5 minutos a mais de 24 horas.

Os materiais alcalinos fazem a limpeza pela quebra dos constituintes gordurosos da sujeira. A vantagem destes tipos de limpadores é que eles necessitam de menor quantidade de água, mas por outro lado há risco de deposição de sais salinos. Por isso, as superfícies devem ser neutralizadas após a execução da limpeza, do contrário ela pode ser manchada.

A utilização de ácidos e bases é usada apenas em circunstâncias específicas, e sempre sob extrema reserva, já que pode resultar em riscos enormes.

Em relação aos solventes orgânicos, os mais comumente utilizados são acetona, metanol e etanol.

O exemplo mais conhecido de agente quelante é o EDTA (ethylene diamine tetra acetic acid). Macchia et al. (2016) testaram vários agentes quelantes para remover ferrugem de mármore.

Apesar de outras técnicas também serem usadas, a remoção de graffiti é feita mais comumente com métodos químicos. Um guia para orientar sua remoção é proposto pela English Heritage (1999). 


\subsubsection{Outras técnicas de limpeza}

Outras técnicas de limpeza incluem o uso de pastas e compressas, sabão e detergentes especiais e limpeza ultrassônica (esta utilizada somente em objetos pequenos) (Figura $7.5 \mathrm{~A})$.

As pastas são normalmente materiais absorventes como argilas, diatomáceas, talco e calcário. É uma maneira pelo qual um solvente ou agente químico é mantido em contato com o substrato por períodos de tempo longos, sendo bastante adequada para se usar em ambientes internos e superfícies ornamentadas.

Recentemente, pastas de látex (Figura 7.5B) contendo pequena quantidade de EDTA têm sido desenvolvidas, baseado na pesquisa e melhoramento da pasta de Mora, que foi desenvolvida em 1970 para limpeza seletiva de pinturas murais.

Nos últimos 5 anos, a pasta de látex Arte Mundit ${ }^{\circledR}$ foi utilizada para limpeza dos interiores do Palácio Royal de Bruxelas, a Catedral de St. Maurice em Angers, e a Catedral de St. Paul em Londres.
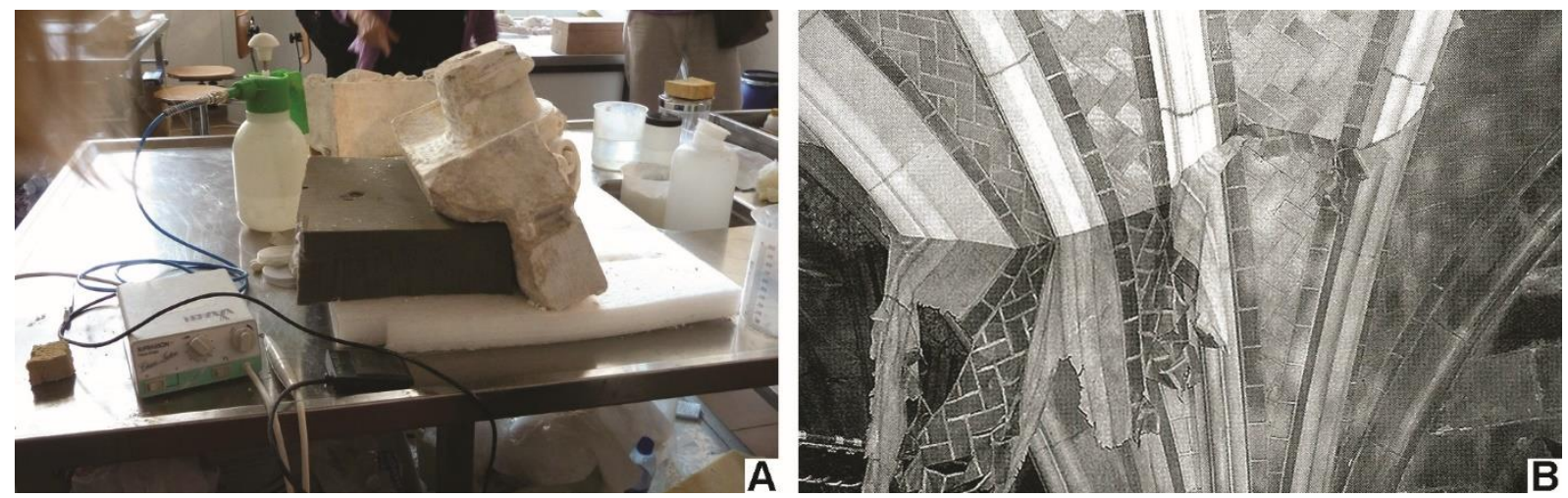

Figura 7.5. Outras técnicas. A. Equipamento de ultrassom, Instituto Centrale del Restauro, Roma, Itália. B. Teste com pasta de látex. Fonte: Normandin \& Slaton (2006).

\subsection{Eliminação de biocolonização}

A eliminação da biocolonização, que consiste no crescimento de elementos biológicos como algas, liquens, fungos, pode ser feita por métodos mecânicos, físicos, químicos ou bioquímicos.

A limpeza utilizando o método mecânico consiste na remoção física com a mão ou ferramentas simples, como bisturis, escovas e raspadores.

Os métodos físicos podem ser aplicados com uso de radiações eletromagnéticas (raios ultravioleta, raios gama, raios beta, raios X), micro-ondas, congelamento e calor.

O método químico é o mais usado na eliminação da biocolonização, tornando o uso de biocidas a prática mais comum na conservação de superfícies arquitetônicas. O importante é o princípio ativo destes biocidas, que são vendidos em diferentes formulações e misturas 
com diferentes nomes comerciais. Um dos mais usado é composto de sais de amônio quaternário.

Um biocida deve ser eficiente, ter baixa toxicidade para o operador, ter baixo risco de poluição ambiental e não interferir nos materiais. Os métodos de aplicação dos biocidas podem ser com uso de pincel, spray, compressa, injeção ou fumigação.

Delgado Rodrigues (2006) afirma que a aplicação simples de biocidas, sem escovação, pode ser suficiente para a eliminação da biocolonização.

O crescimento biológico pode ser inibido com a presença de metais pesados, como por exemplo o cobre e o zinco, ou mesmo ligas metálicas como o bronze. Este processo é facilmente visualizado em cemitérios, onde abaixo de objetos de liga de cobre de decoração ou de inscrição não se instala colonização biológica (Figura 7.6), mesmo em condições propícias para isso.

Exemplos de aplicação de biocidas e outros tratamentos para eliminar a biocolonização em monumentos pétreos são encontrados em Kumar \& Kumar (1999), Charola et al. (2011) e Delgado Rodrigues et al. (2012).

\subsection{Consolidantes}

A substituição de partes deterioradas por pedra ou argamassa já foi uma prática muito comum antigamente, mas hoje, com o desenvolvimento e utilização de consolidantes para recuperação dos materiais pétreos deteriorados, essa prática tornou-se uma exceção nos trabalhos de conservação e restauro.

O artigo 10 da Carta de Veneza diz:

Quando as técnicas tradicionais se revelarem inadequadas, a consolidação de um monumento será assegurada, com o recurso de todas as técnicas modernas de conservação e de construção, cuja eficácia tenha comprovação científica e garantia firmada pela experiência. (ICOMOS 1964)

Os objetivos da consolidação são aumentar a resistência da pedra, limitar as perdas devido à deterioração e restaurar as propriedades físicas da pedra, restringindo e diminuindo sua deterioração.

A princípio, qualquer pedra pode ser consolidada, mas se estiver em processo muito avançado de alteração o consolidante não surtirá efeito, pois não é capaz de ligar espaços muito grandes em termos moleculares.

Assim, a escolha e utilização de um consolidante deve se pautar pela demonstração de sua eficácia por meio de testes in situ e em laboratório, pesquisa bibliográfica e exemplos onde foi aplicado, sua durabilidade e a existência de efeitos colaterais ou não. 

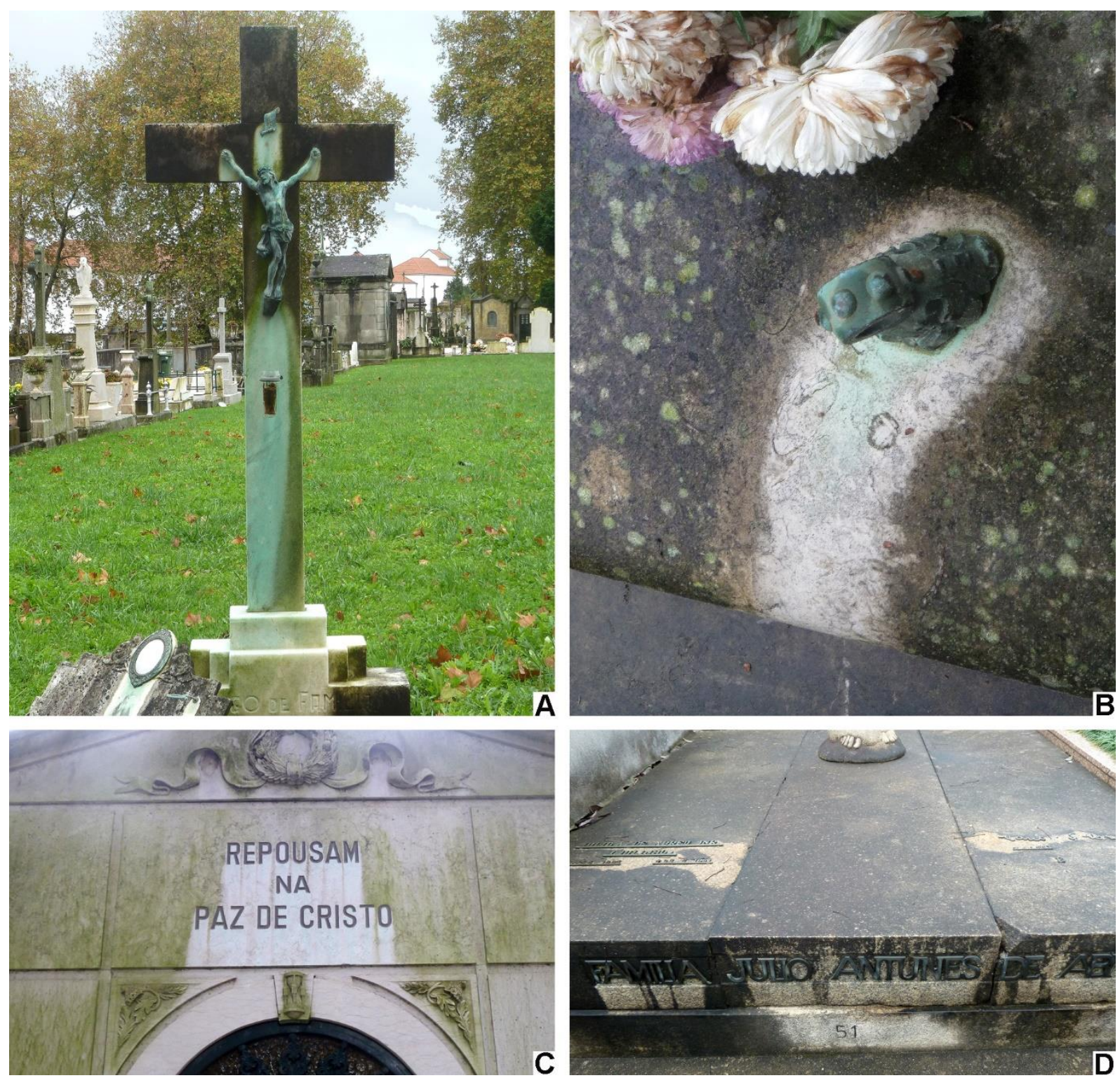

Figura 7.6. Biocidas acidentais. Em cemitérios é muito comum observar que abaixo de objetos de liga de cobre não se instala colonização biológica. A. Cemitério Prado do Repouso, Porto, Portugal. B e C. Cemitério dos Prazeres, Lisboa, Portugal. D. Cemitério da Consolação, São Paulo.

\section{Todo consolidante deve:}

- melhorar significativamente as propriedades da pedra, tais como resistência à compressão, elasticidade e resistência à abrasão;

- ter as mesmas características de dilatação térmica e hídrica da pedra;

- ser capaz de penetrar suficientemente em profundidade na pedra;

- fornecer um perfil de resistência para a pedra com redução gradual para o interior;

- permitir futuro retratamento. 
Um consolidante não deve:

- afetar a estrutura de poros da pedra;

- criar interfaces fortes entre as áreas tratadas e não tratadas;

- formar subprodutos prejudiciais;

- alterar significativamente a aparência da pedra (cor, textura ou reflectância de superfície);

- promover ou favorecer o crescimento microbiológico;

- afetar a manutenção de médio e longo prazo.

É impossível falar de consolidantes sem entender química orgânica. Por isso, serão apresentados alguns conceitos a seguir.

Este item é baseado na publicação de George Wheeler: Alkoxysilanes and the consolidation of stone (2005), uma das mais completas sobre o tema, referenciando inúmeros artigos e leitura obrigatória para quem trabalha com consolidantes. Atualmente, é possível fazer o download deste livro no site do Institute Getty (http://www.getty.edu/conservation/publications_resources/pdf_publications/pdf/alkoxysilanes_vl. pdf).

\subsubsection{Conceitos de Química Orgânica}

O elemento chave da Química Orgânica é o carbono. Ele pode fazer quatro ligações, ou seja, é tetravalente, com ele mesmo ou com outros elementos. Quando forma ligação dupla ou tripla com o próprio $\mathrm{C}$ é referido como instauração.

Outros elementos mais frequentemente ligados ao $\mathrm{C}$ são $\mathrm{H}, \mathrm{O}$ e $\mathrm{N}$.

A ligação dupla $\mathrm{C}$ e $\mathrm{O}$ é chamada carbonila. Outro grupo funcional que se liga ao $\mathrm{C}$ é a hidroxila, $\mathrm{OH}$.

Os átomos de C podem se ligar sucessivamente, formando cadeias de grandes moléculas chamadas de polímeros.

Se os compostos forem formados somente por $\mathrm{C} \mathrm{e} \mathrm{H}$, tem-se os hidrocarbonetos. $\mathrm{O}$ grupo mais simples de hidrocarboneto é o alcano, com apenas ligações simples entre os átomos de $\mathrm{C}$. O menor composto deste grupo é o metano $\left(\mathrm{CH}_{4}\right)$. A nomenclatura muda conforme o aumento do número de $\mathrm{C}$ : etano $\left(\mathrm{C}_{2} \mathrm{H}_{6}\right)$, propano $\left(\mathrm{C}_{3} \mathrm{H}_{8}\right)$, butano $\left(\mathrm{C}_{4} \mathrm{H}_{10}\right)$, e assim sucessivamente, com fórmula geral $\mathrm{C}_{n} \mathrm{H}_{2 n+2}$. Se o $\mathrm{C}$ fizer uma ligação dupla, tem-se os alquenos, com fórmula geral $\mathrm{C}_{n} \mathrm{H}_{2 n}$. $\mathrm{E}$ se o $\mathrm{C}$ fizer uma ligação tripla, tem-se os alquinos, com fórmula geral $\mathrm{C}_{n} \mathrm{H}_{2 n-2}$.

Os hidrocarbonetos podem ser cíclicos, formando compostos alifáticos (alcanos, alquenos ou alquinos com cadeias fechadas) ou aromáticos (cadeias fechadas alternando ligações simples e duplas).

Se é adicionado um átomo de $\mathrm{O}$ entre a ligação de $\mathrm{C}$ e $\mathrm{H}$, é formado um grupo de compostos denominado álcool. A nomenclatura é similar aos alcanos: álcool metílico ou 
metanol $\left(\mathrm{CH}_{3}-\mathrm{OH}\right)$, álcool etílico ou etanol $\left(\mathrm{CH}_{3} \mathrm{CH}_{2}-\mathrm{OH}\right)$, álcool propílico ou propanol $\left(\mathrm{CH}_{3} \mathrm{CHCH}_{3}-\mathrm{OH}\right)$, e assim sucessivamente.

Oxigênio pode ser colocado entre 2 átomos de $\mathrm{C}$ (-C-O-C-), formando os éteres. A nomenclatura se dá com o nome do alcano à direita do $\mathrm{O}$, sufixo oxi e nome do alcano à esquerda. Os éteres são miscíveis com hidrocarbonetos e alcoóis.

Uma carbonila ligada a um éter origina os ésteres. A nomenclatura se dá com o nome do alcano à direita do $\mathrm{O}$, sufixo ato, nome do alcano à esquerda e sufixo ila.

carbonila II

C - O - C éter

A ligação entre carbonila e hidroxila origina os ácidos carboxílicos ou ácidos orgânicos. A nomenclatura se dá com o nome do ácido, nome do alcano e sufixo oico.

carbonila II

\section{C - OH hidroxila}

Os silanos são análogos aos alcanos, com o Si no lugar do C.

Wheeler (2005) não usa o termo silano para os consolidantes de pedra baseados em alcoxissilano, já que o termo significa o composto $\mathrm{SiH}_{4}$ ou a raiz para a classe de compostos de $\mathrm{Si}$, preferindo utilizar a própria denominação alcoxissilano. Alcoxissilano, como um grupo, é também denominado na literatura de éster de silício (silicon esters), éster de ácido silícico (silicic acid esters), ortossilicatos e alquilssilicatos. Para o composto tetraetoxissilano (TEOS), são encontrados os seguintes nomes: silicato de etilo, tetraetilortossilicato e silicic acid ethyl ester. Este autor usa o termo silicato de etilo para tetraetoxissilano parcialmente polimerizado.

O grande interesse no alcoxissilano para uso na consolidação da pedra é devido a sua baixa viscosidade e habilidade em formar ligações Si-O-Si (siloxano).

Nos silanos, cada $\mathrm{H}$ pode ser substituído por outros elementos ou grupos. Estes podem ser reativos determinando a funcionalidade do composto. A funcionalidade que nos interessa é a ocorrência da hidrólise:

$$
\mathrm{Si}-\mathrm{X}+\mathrm{H}_{2} \mathrm{O} \rightarrow \mathrm{Si}-\mathrm{OH}+\mathrm{HX}
$$

sendo que um dos produtos desta reação é o silanol, Si-OH, que reagindo com outro silanol, produz ligações de siloxano em uma reação de condensação:

$$
\mathrm{Si}-\mathrm{OH}+\mathrm{HO}-\mathrm{Si} \rightarrow \mathrm{Si}-\mathrm{O}-\mathrm{Si}+\mathrm{H}_{2} \mathrm{O}
$$


Os grupos reativos mais comuns são $\mathrm{H}, \mathrm{F}, \mathrm{Cl}$ e $\mathrm{RO}$, onde $\mathrm{R}$ é o símbolo geral para os grupos alquil, tais como, metil $\left(\mathrm{CH}_{3}\right)$ ou etil $\left(\mathrm{CH}_{3} \mathrm{CH}_{2}\right)$. Os grupos $\mathrm{RO}$ são chamados alcoxi (alkil + oxigênio), por exemplo, metoxi $\left(\mathrm{CH}_{3} \mathrm{O}\right)$ e etoxi $\left(\mathrm{CH}_{3} \mathrm{CH}_{2} \mathrm{O}\right)$. Se os $4 \mathrm{H}$ são substituídos por grupos alcoxi, formam-se tetrametoxissilano (TMOS), $\mathrm{Si}\left(\mathrm{OCH}_{3}\right)_{4}$, e tetraetoxissilano (TEOS), $\mathrm{Si}\left(\mathrm{OCH}_{2} \mathrm{CH}_{3}\right)_{4}$.

Wheeler (2005) demonstra que poucos compostos são adequados para consolidar a pedra, restringindo-se a alguns metoxi e etoxissilanos. Apesar de que muitos compostos formam ligações de siloxano, somente poucos compostos de silício tri- e tetrafuncional formam gel e têm o balanço adequado entre volatilidade e reatividade, não sendo prejudiciais nem para a pedra, nem para as pessoas, sendo aplicáveis nos trabalhos de consolidação da pedra.

\subsubsection{Histórico}

Os primeiros produtos usados para fins de consolidação foram água de cal, óleo de linhaça e outros. Mas utilizando a química moderna, a consolidação da pedra iniciou-se no começo do século XIX, quando J. J. Berzelius sintetizou o tetracloreto de silício em 1824. Outras sínteses de compostos baseados em silício foram obtidas: Ebelmen sintetiza tetraetoxissilano em 1846, Ladenberg sintetiza metiltrietoxissilano em 1874 e, em 1904, é sintetizado metiltrimetoxissilano, provavelmente por Kipping. Este três compostos são alcoxissilanos.

A. W. von Hoffman sugeriu o uso de éter silícico (silicic ether), uma forma de tetraetoxissilano (TEOS) ou silicato de etilo, para consolidação das pedras deterioradas do Parlamento de Londres em 1861.

Na década de 20 do século passado, A. P. Laurie adquire diversas patentes no Reino Unido e nos Estados Unidos para a consolidação de pedra com silicato de etilo. A eficácia deste composto foi questionada por R. J. Schaffer em 1932 em sua publicação The Weathering of Natural Building Stone.

Durante o período de 1930 a 1950 houve utilização esporádica de silicato de etilo e alquilalcoxissilanos para a consolidação da pedra.

Em 1956, H. Plenderleith aponta um aumento de resistência de rochas silicosas após a aplicação de éster de silício (silicon ester), em sua obra The Conservation of Antiquities and Works of Art.

Em 1964, Schaffer critica todos os ensaios feito com silicato de etilo e desencoraja seu uso, situação que se inverte no final da década de 1960 e início de 1970, quando o estudo e o uso de alcoxissilano em pedra começa a se disseminar, com os trabalhos de S. Z. Lewin, K. Hempel e A. Moncrieff.

Estes dois últimos autores trabalharam com metiltrimetoxissilano (MTMOS) para a consolidação de mármore.

Wacker inicia o desenvolvimento de consolidantes baseados em tetraetoxissilano e tetraetoxissilano-metiltrietoxissilano, atualmente denominados Wacker $\mathrm{OH}$ e Wacker $\mathrm{H}$, respectivamente. 
O Building Research Establishment começa a trabalhar em um consolidante baseado em metiltrimetoxissilano (MTMOS) catalisado, mais tarde chamado Brethane, porém atualmente não sendo mais produzido.

Na década de 1970, expandiu-se o uso de metiltrimetoxissilano (MTMOS) e Wacker $\mathrm{OH}$ e $\mathrm{H}$. A Goldschmidt desenvolve o Tegovakon T e V, e a Rhone-Poulenc desenvolve produtos que mais tarde seriam denominados RC70, RC80 e RC90.

Na década de 1980, a ProSoCo comercializa produtos Wacker nos Estados Unidos com os nomes Conservare $\mathrm{OH}$ e $\mathrm{H}$.

Os alcoxissilanos tornam-se parte do repertório geral de conservação da pedra e seu uso é estendido para as rochas vulcânicas, granitos, calcários e mármores.

Os TEOS foram mais desenvolvidos na Alemanha para os arenitos e o MTMOS foram mais usados na Inglaterra para calcários. Atualmente TEOS também é usado em calcários e mármores.

\subsubsection{Consolidação de pedras}

Previamente aos trabalhos de consolidação de uma pedra, deve-se fazer uma caracterização e um diagnóstico preciso de suas características e as causas de sua deterioração, de forma que o uso do consolidante seja eficaz, sendo capaz de penetrar profundamente na pedra em um período de tempo razoável, para então se solidificar, alcançando o resultado desejado.

Desta forma, as propriedades desejadas de um consolidante ideal a ser utilizado são:

- ser estável à luz;

- ter baixo conteúdo orgânico volátil (VOC);

- ter baixa toxicidade;

- ter alta temperatura de transição vítrea;

- ser fácil de usar e aplicar;

- ter profundidade de penetração adequada;

- ser reversível-retrabalhável;

- ser compatível com outras atividades de conservação;

- manter a aparência inicial da pedra;

- limitar futura deterioração;

- ser aplicável a todos os tipos de pedra.

Como não existe "o" consolidante com todas estas características, é necessário sempre se testar o produto antes de sua aplicação no tratamento de consolidação.

O trabalho de consolidação das pedras é fortemente influenciado pela sua composição mineral, porosidade e forma e tamanho dos grãos (Figura 7.7). Desta forma, deve-se ter em 
mente que somente o litotipo não é suficiente para se fazer a escolha do tipo de consolidante a ser utilizado no trabalho de consolidação de uma pedra.
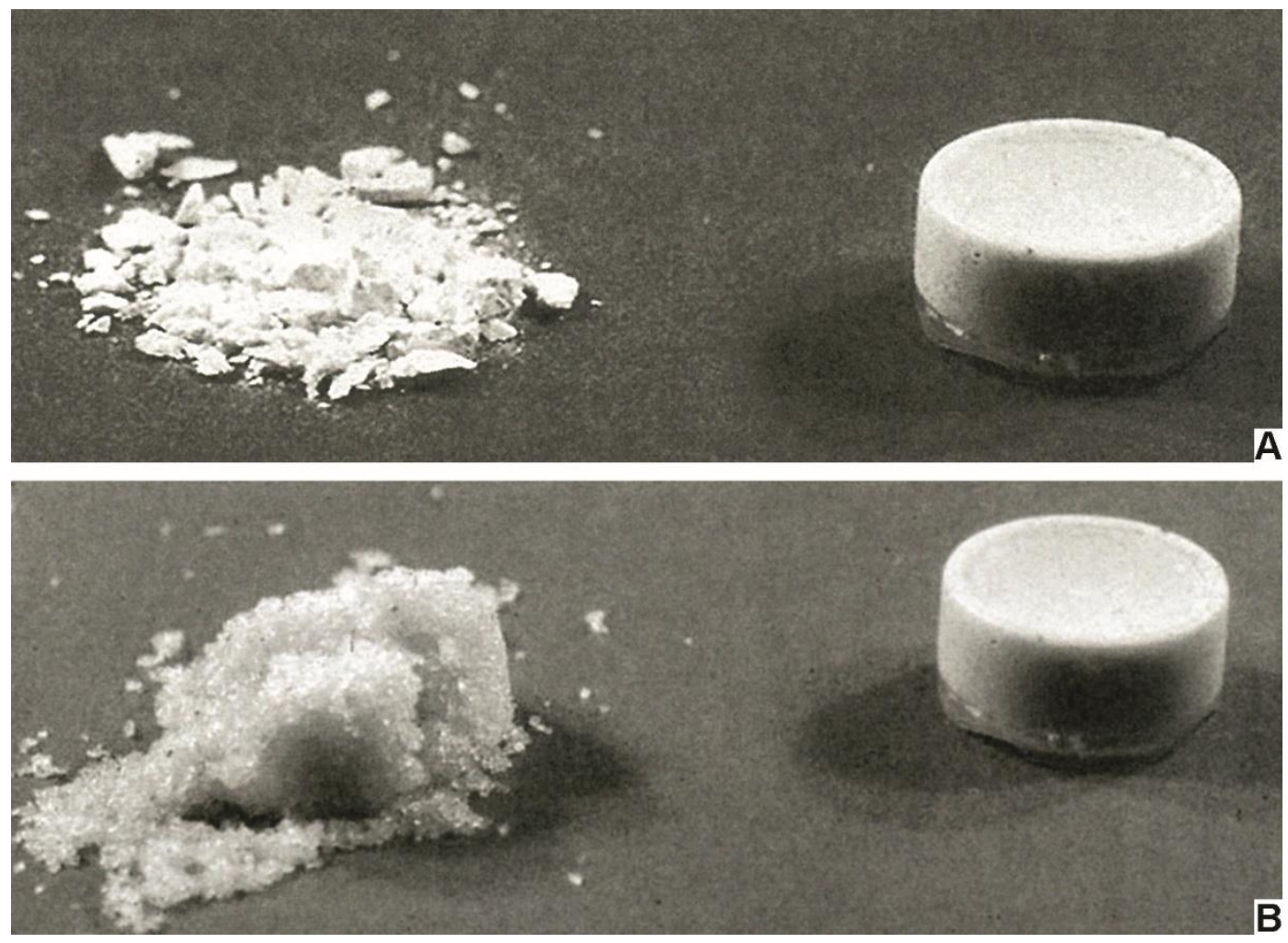

Figura 7.7. Influência da composição mineral e da granulometria na consolidação de pedra. A. Pó (0,075 mm) de calcita e quartzo tratado com metiltrimetoxissilano (MTMOS). O pó de quartzo, à direita, é consolidado, e pó de calcita permanece em pó. B. À direita, pó $(0,075 \mathrm{~mm})$ de quartzo consolidado com MTMOS. À esquerda, grãos maiores $(0,4 \mathrm{~mm})$ não são consolidados, devido ao grande espaço intergranular. Fonte: Wheeler (2005).

A estimativa de quantidade de consolidante a ser usada pode ser feita utilizando-se a seguinte fórmula:

área superficial $\mathrm{x}$ porosidade $\mathrm{x}$ profundidade de penetração $=$ volume do consolidante

onde a porosidade pode ser estimada com uso de tubos de Karsten.

Os dados da literatura apontam uma quantidade de consumo que varia de 1 a $40 \mathrm{~L} / \mathrm{m}^{2}$ de consolidantes, sendo que Arnold (1978) e Price (1981, apud Wheeler 2005) apresentam um valor médio de cerca de $5 \mathrm{~L} / \mathrm{m}^{2}$.

Ferreira Pinto \& Delgado Rodrigues (2008) fazem uma análise dos procedimentos adotados na consolidação da pedra com relação à quantidade de produto absorvido, a profundidade de penetração e as propriedades mecânicas da porção consolidada.

Há dois grandes grupos de consolidantes: inorgânicos e orgânicos. 


\subsubsection{Consolidantes inorgânicos}

Dentre os consolidantes inorgânicos tem-se o hidróxido de cálcio (água de cal), hidróxido de bário, e o fosfato de amônio e hidrogênio (DAP).

A consolidação com utilização de hidróxido de cálcio foi proposto por Baker no começo dos anos 1960.

O método da cal, como também é chamado, é o mesmo do endurecimento de uma argamassa de cal. Aplica-se uma solução de hidróxido de cálcio em um calcário, que penetra na pedra. Com a evaporação, ocorrerá deposição de hidróxido de cálcio, que por sua vez reagirá com o $\mathrm{CO}_{2}$ atmosférico e formará carbonato de cálcio. Estes consolidantes não são passíveis de ser utilizados no calcário muito deteriorado, assim como também não se aplicam à recuperação de arenitos não carbonáticos.

O hidróxido de cálcio foi adotado em estátuas de calcário da Catedral de Wells, na Inglaterra, entre 1974 e 1986, e até os dias atuais só necessitou de pequenas manutenções (Price 2006).

De acordo com Hansen et al. (2003), bactérias sintetizadoras de calcita têm sido usadas como um método alternativo de deposição de carbonato de cálcio em calcário deteriorados. Esses autores fazem uma revisão sobre consolidantes inorgânicos e tratamentos de proteção para materiais calcários porosos.

Recentemente, surgiu a tecnologia de nanocal. As nanopartículas de hidróxido de cálcio são dispersas em álcool, favorecendo penetração mais profunda do consolidante na pedra (Doehne \& Price 2010).

O método do hidróxido de bário ou água de barita foi proposto por Church na metade do século XIX, para tratar calcário e mármore (Honeyborne et al. 1990).

O hidróxido de bário pode converter o sulfato de cálcio em sulfato de bário, que é insolúvel em água, reduzindo desta forma o risco de ocorrência de mais danos pela cristalização de sais. Na prática, a espessura da camada formada por sulfato de bário é muito pequena, não sendo muito eficiente sua utilização.

Delgado Rodrigues \& Ferreira Pinto (2016) utilizaram o hidróxido de bário para fazer a consolidação de dois calcários altamente porosos, demonstrando que este composto carbonata com $0 \mathrm{CO}_{2}$ atmosférico, seja o hidróxido de bário que permanece livre, seja o hidróxido de cálcio que resulta da prévia substituição do cálcio pelo bário na estrutura da calcita existente, quando o tempo de contato é suficiente para tal.

Outra aplicação do hidróxido de bário é para a conservação de pinturas murais, num processo de duas etapas, com aplicação de carbonato de amônio, denominado método florentino (originalmente proposto por Ferroni et al. 1969, e refinado por Matteini 1991, apud Chiari 2000). O princípio do método consiste em eliminar a contaminação da gipsita, presente frequentemente, primeiro tratando com carbonato de amônio, que vai produzir calcita e sulfato de amônio. Em seguida, a aplicação de hidróxido de bário fixa os íons sulfato, transformando-os em sulfato de bário, totalmente insolúveis. A consolidação continua, já que o excesso de hidróxido de bário transforma-se espontaneamente em carbonato de bário insolúvel, tendo como resultado final uma superfície muito consolidada. 
Ainda com relação a pinturas murais, Snethlage et al. (2008) propõem a utilização do ammonium-dihydrogen-phosphate (DAP) para consolidar pintura de cal. Uma solução com DAP reage com calcita presente nos calcários e forma hidroxiapatita e outras fases precursoras fosfatadas.

Sassoni et al. (2011) apontam que a técnica de consolidação com utilização do DAP é promissora para rochas carbonáticas. Estes autores utilizaram este consolidante no Calcário Indiana com sucesso, já que a hidroxiapatita é muito menos solúvel que a calcita e tem estrutura cristalina similar à calcita, além de melhorar as propriedades mecânicas da pedra, não é tóxica, penetra consideravelmente $(>2 \mathrm{~cm})$ e altera pouco a distribuição do tamanho dos poros.

\subsubsection{Consolidantes orgânicos}

O processo de consolidação com utilização de consolidantes orgânicos consiste em uma reação de polimerização, ou seja, impregnar a pedra com um monômero, e então induzir a polimerização in situ. Monômeros são moléculas relativamente pequenas que podem reagir para fazer uma molécula muito maior, um polímero. Monômeros são frequentemente líquidos de baixa viscosidade, enquanto polímeros são frequentemente sólidos.

Os consolidantes orgânicos devem ter baixa viscosidade, o que é obtido adicionando um solvente de baixa viscosidade, o que faz com que o consolidante tenha fluidez suficiente para atingir maior penetratividade.

Nos estudos para avaliar o desempenho do consolidante, as seguintes análises podem ser realizadas, antes e após o tratamento: determinação da porosidade, ensaios de capilaridade, permeabilidade do vapor de água, resistência à flexão, determinação da velocidade ultrassônica e medição de cor.

Dentre os consolidantes orgânicos, os mais usados na consolidação da pedra são alcoxissilanos, polímeros acrílicos, resina de poliéster e resina epóxi.

Honeyborne et al. (1990) apresentam uma discussão sobre os consolidantes e a química estrutural destes materiais.

Price (2006) considera como consolidantes orgânicos apenas silanos e polímeros acrílicos.

Como já citado no item 7.2.1, os alcoxissilanos reagem com água para formar polímeros. Uma vez formada a ligação química nos polímeros, esta não pode ser quebrada por solventes, o que significa que tratamentos que usam estes consolidantes são irreversíveis. Alguns alcoxissilanos têm propriedades hidrorrepelentes devido à presença de metil $\left(\mathrm{CH}_{3}\right)$ ou etil $\left(\mathrm{C}_{2} \mathrm{H}_{5}\right)$.

O alcoxissilano mais importante em conservação de pedra é o tetraetoxissilano (TEOS). A hidrólise do TEOS gera tetrahidroxissilano, as moléculas de tetrahidroxissilano vão reagir com outras moléculas de tetrahidroxissilano. Este processo continuará até que todo o carbono presente seja convertido em álcool. Neste ponto, os átomos de Si e O na razão de 1:2 terão formado uma rede de sílica. 
Exemplos comerciais de TEOS são: Wacker $\mathrm{OH}$, Tegovakon V, RC70, Keim OH, Remmers 300 e 500, e Conservare $\mathrm{OH}$. Existem também produtos com propriedades hidrófugas, tais como: Wacker H, Tegovakon T, RC80 e RC90.

O metiltrimetoxissilano (MTMOS) é o membro mais simples da família dos alquiltrialcoxissilanos. Ele também reage com água para formar uma rede de átomos de Si e O. Porém, cada átomo de $\mathrm{Si}$ tem um radical metil e somente 3 átomos de $\mathrm{O}$. Devido à presença do radical metil, este material teria a propriedade de repelência de água em detrimento do poder de consolidação. Como o álcool metílico é venenoso, todo sistema de consolidação usando um alquilmetoxissilano deveria ser realizado em condições muito bem ventiladas. Substratos de calcita consolidados com MTMOS favorecem a evaporação do silicato de etilo retardando a reação de condensação, constituindo-se um problema, mas que pode ser minimizado com a utilização de formulações catalisadas, como o TEOS.

Em substratos de quartzo e arenito, o gel formado com a aplicação do solvente adquire a forma de folha, e embora craqueado adapta-se à superfície mineral. Em calcita e calcário, o gel é esponjoso ou aparece isolado, não recobrindo a superfície. Em mármore com desintegração granular, os espaços entre os poros são como folhas, facilitando a deposição do gel (Wheeler 2005).

Por outro lado, Grissom et al. (1999) realizaram consolidação de estátuas de argamassa de cal com sucesso, utilizando silicato de etilo, obtendo um aumento em mais de $300 \%$ da sua resistência. $\mathrm{O}$ consolidante formou uma rede uniforme e nenhum tipo de craquelamento foi observado, mesmo após 11 anos de sua consolidação.

$\mathrm{Na}$ aplicação de consolidante, os poros maiores são revestidos, enquanto os poros menores são preenchidos. O espaço máximo que pode ser ligado com silicato de etilo é de $50 \mu \mathrm{m}$, o que daria uma granulometria de aproximadamente $325 \mu \mathrm{m}$ (Wendler et al. 1999, Rolland et al. 2000, apud Wheeler op. cit.).

Segundo Wheeler (op. cit.), o gel do silicato de etilo tende a se depositar nos poros pequenos $(<50 \mu \mathrm{m})$, alterando a porosidade da pedra. Este autor cita vários estudos onde houve alteração da porosidade após tratamento com silicato de etilo.

A aplicação de consolidantes pode provocar alteração na cor ou escurecimento da pedra tratada. A mudança cromática está condicionada à presença de minerais máficos e félsicos na sua composição: quanto maior a quantidade de minerais máficos, maior a mudança de cor (Figuras 7.8 e 7.9 ).

Oliver (2002, apud Wheeler op. cit.) estabelece que a efetividade do tratamento com silicato de etilo depende de 3 fatores: composição original da pedra, sua condição atual, e o mais importante, se a causa da deterioração pode ser eliminada.

A aplicação de alcoxissilano deve respeitar as seguintes condições:

- a temperatura do ar e da superfície da pedra deve estar entre 10 e $32^{\circ} \mathrm{C}$;

- a superfície a ser tratada deve estar protegida do sol;

- a superfície deve estar seca;

- a umidade relativa deve estar entre 40 e $80 \%$;

- a pedra não deve ter colonização biológica. 

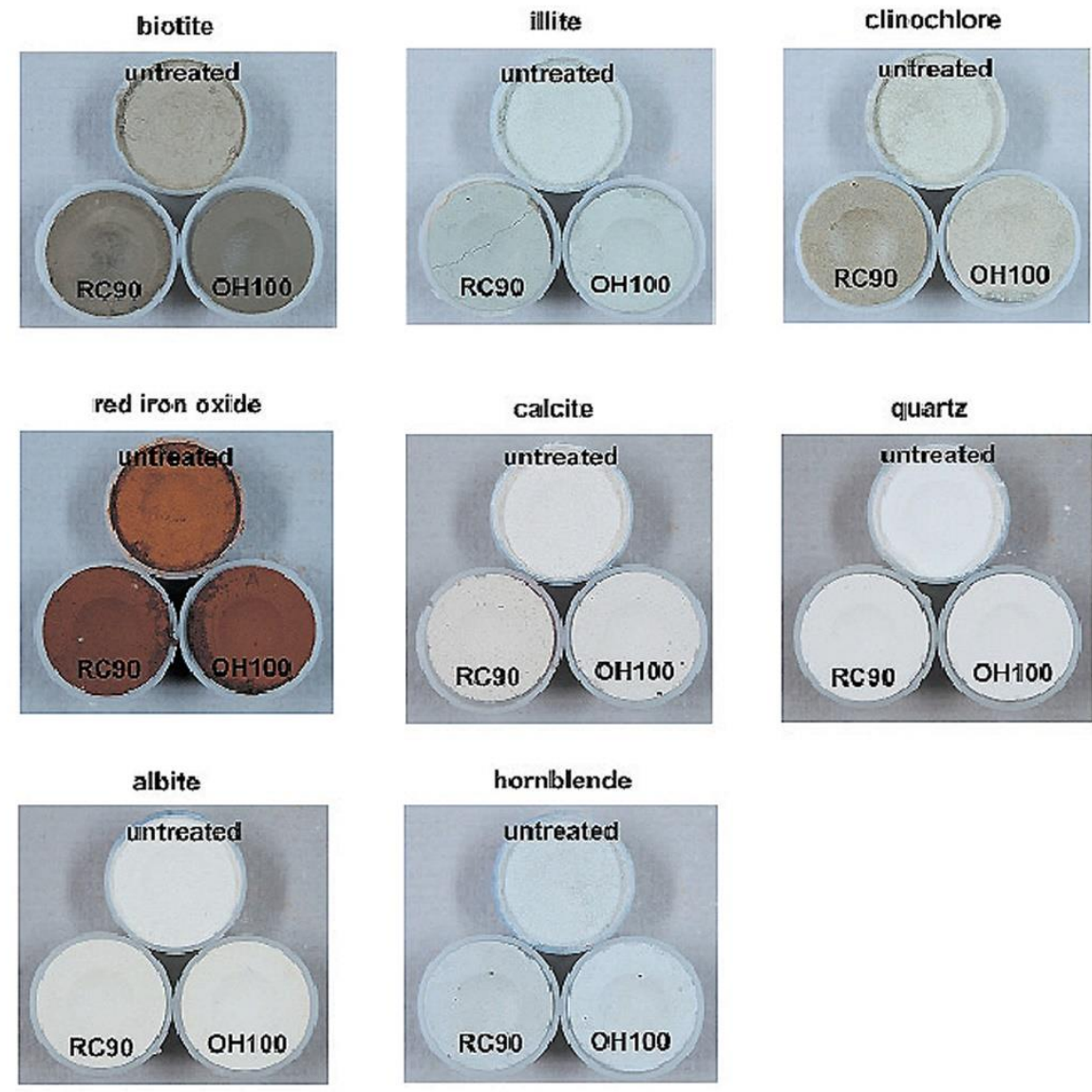

Figura 7.8. Pó de minerais consolidados com RC90 e Wacker OH100. Notar maior escurecimento nos minerais máficos. Fotografias: John Campbell. Fonte: Wheeler (2005).

As resinas acrílicas usadas em conservação são provenientes de duas famílias de monômeros: os acrilatos e metacrilatos.

Um exemplo muito utilizado em conservação é o Paraloid B72, um copolímero de etil metacrilato e metil acrilato. Dissolve-se em vários solventes mas é mais frequentemente utilizado em misturas de acetona e etanol.

As resinas acrílicas têm sido usadas desde o final dos anos 1960 e são por vezes utilizadas como adesivos, embora não sejam muito fortes, mesmo em altas concentrações, e seu uso é desfavorecido por causa da umidade, o que as torna impróprias para o uso exterior. Geralmente são usadas apenas para a fixação de pequenas lascas de pedra ou para preencher as rachaduras e vazios pequenos, misturadas com pó da pedra finamente moído.

As resinas acrílicas são dissolvidas em solventes orgânicos, tais como: acetona, tolueno ou xileno. Concentrações típicas estão entre $2-5 \%$ de consolidantes em solventes por peso/volume. O tipo de solvente e a concentração da solução variam conforme o tipo de pedra e a profundidade de consolidação.

Este polímero termoplástico é classificado como polimetilmetacrilato, PMMA. 

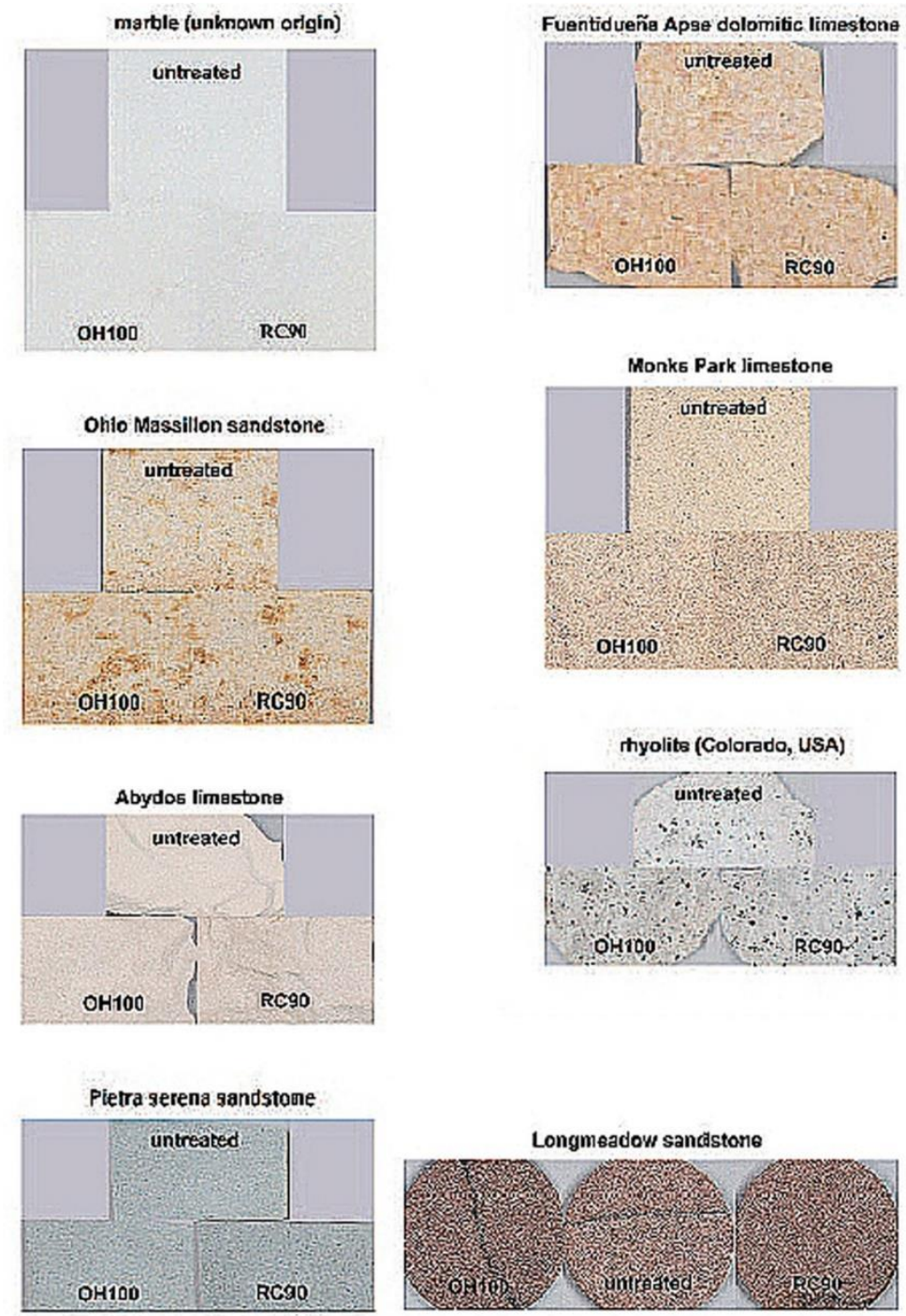

Figura 7.9. Pedras consolidadas com Wacker OH100 e RC90. Fotografias: John Campbell. Fonte: Wheeler (2005).

A resina de poliéster tem tempo de endurecimento rápido, entre 5 a 30 minutos. O tempo de cura depende da quantidade de catalisador e da temperatura ambiente: se a temperatura cair abaixo de $10^{\circ} \mathrm{C}$, a resina não endurece. A reação de cura é exotérmica, e, após cura completa, torna-se quebradiça e opaca. A maioria é incolor quando seca. A reação da cura é teoricamente reversível, mas observa-se que na prática ela não é reversível.

As resinas epóxi são muito fortes e estáveis, e não são aparentemente afetadas pela degradação ambiental, tais como umidade e calor; mas são altamente suscetíveis ao amarelamento.

Elas são curadas por um endurecedor ao invés de um catalisador, e por isso são normalmente fornecidos em pacotes de duas partes. A resina e o endurecedor devem ser misturados na proporção correta indicada pelo fabricante.

Um exemplo de aplicação da resina epóxi é a aplicação na Porta Real da Catedral de Chartres, entretanto, devido ao resultado obtido, em que se mostrou quebradiça, viscosa e tendo originado um material amarelado, não pode ser considerada um bom consolidante. 


\subsubsection{Estudo de caso: Teatro Municipal de São Paulo}

A durabilidade das pedras usadas nas construções é afetada pela presença de minerais expansíveis em sua constituição (Delgado Rodrigues 2001). Um exemplo deste processo é - Arenito Itararé, presente como revestimento na fachada do Teatro Municipal de São Paulo (Figura 7.10), e que possui argilomineral expansivo do grupo da esmectita em sua constituição.

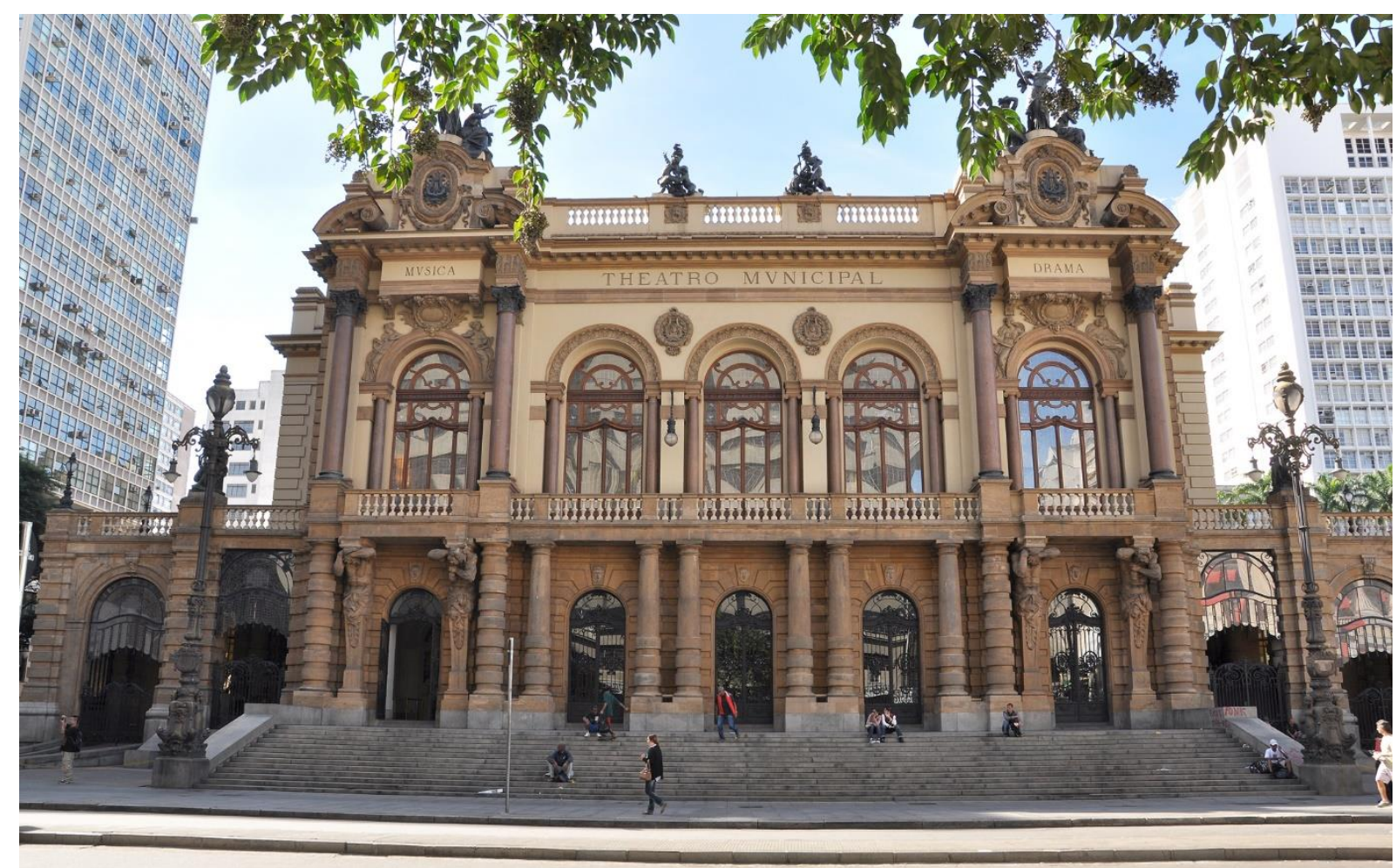

Figura 7.10. Teatro Municipal de São Paulo. Fotografia: Lauro K. Dehira.

Para o tratamento de pedras que contenham argilominerais expansivos na sua constituição, Scherer \& Jiménez-González (2008) propõem a utilização de inibidores de expansão, tais como os diaminoalcanos (DAA), para execução de pré-consolidação. Esta técnica já tinha sido usada por Snethlage \& Wendler (1991), que demonstraram que o diaminoalcano poderia reduzir a expansão de argilominerais.

O tratamento consiste na aplicação de cadeia de alcano linear hidrofóbico com grupos de amino protonado em cada extremidade, que podem substituir o cátion entre as camadas de argilominerais e ligar folhas opostas, enquanto a cadeia hidrofóbica inibe a entrada de água (Wangler \& Scherer 2009). Estes autores mostraram que quanto maior a cadeia de carbono maior a redução da expansão. A inibição completa da expansão dos argilominerais não é possível de ser efetuada com os conhecimentos atualmente disponíveis, o que demanda maiores investigações nessa área.

Sassoni et al. (2013) demonstraram a eficiência da consolidação do fosfato de amônio e hidrogênio (DAP) em arenitos com proporções variáveis de carbonato, realçando a 
vantagem de não alterar a distribuição do tamanho dos poros e nem as propriedades de transporte de água ou do vapor de água. Mas para o DAP funcionar é preciso que tenha cálcio na pedra.

A aplicação de consolidantes no Arenito Itararé foi realizada por Grossi (2016). Neste estudo, foram usados DAAs, DAP e TEOS, e verificado o desempenho destes produtos baseando-se em análises de espectrofotometria, velocidade de ondas ultrassônicas, tubo de Karsten, saturação a vácuo, capilaridade, porosimetria de mercúrio, ciclos de saturação e secagem, profundidade de penetração, microscopia eletrônica de varredura (MEV), e ensaio de intemperismo acelerado por $\mathrm{SO}_{2}$. Após a realização dos tratamentos, não houve comprovação de que um produto se comportasse melhor em todos os testes. O DAA aumentou o valor da velocidade de ondas ultrassônicas, não alterou muito a distribuição do tamanho dos poros (atestada pela porosimetria de mercúrio no laboratório brasileiro) e penetrou em maior profundidade. Vale lembrar que o DAA é um pré-consolidante. $O$ tratamento com DAA seguido de DAP também aumentou a velocidade e se comportou bem no teste de porosimetria de mercúrio (realizada em laboratório americano), além de alterar menos a cor. O TEOS comporta-se melhor após ciclos de saturação e secagem. Assim, a avaliação da autora no presente estudo é que o mais adequado à consolidação do Arenito Itararé foi a aplicação de DAA seguida de DAP, com base nos resultados do desempenho, disponibilidade e custo dos produtos. Os dois últimos fatores têm papel importante quando se transporta a teoria para a prática. Neste mesmo estudo, também verificou a aplicabilidade de produtos hidrofugantes e antigraffiti.

\section{REFERÊNCIAS}

Brandi C. 1963. Teoria da Restauração. Trad.: B.M. Kühl, 2004. Cotia, Ateliê Editorial, 261 p.

BS - British Standard. 2012. 8221-2: Code of practice for cleaning and surface repair of buildings. Cleaning of natural stone, brick, terracotta and concrete. British Standards Institution. 26 p.

Charola A.E., McNamara C., Koestler R.J. 2011. Biocolonization of stone: control and preventive methods. In: MCI Workshop Series. Washington D.C., Smithsonian Institution Scholarly Press, Proceedings, 117 p. (Smithsonian Contributions to Museum Conservation, n. 2).

Chiari G. 2000. Mineralogy and cultural heritage. In: Vaughan D.J. \& Wogelius R.A. (eds.) Environmental Mineralogy. EMU Notes in Mineralogy, 2:351-381.

Delgado Rodrigues J. 2001. Swelling behaviour of stones and its interest in conservation - an appraisal. Materiales de construcción, 51(263-264):183-195.

Delgado Rodrigues J. 2006. Notas de aula da disciplina GMG5867 - Conservação e Restauração do Patrimônio Histórico Construído. Curso ministrado no Instituto de Geociências da USP.

Delgado Rodrigues J. \& Ferreira Pinto A.P. 2016. Laboratory and onsite study of barium hydroxide as a consolidant for high porosity limestones. Journal of Cultural Heritage, 19: 467-476. 
Delgado Rodrigues J., Charola A.E., Vale Anjos M.A. 2012. Stone statuary and biocolonization. In: Charola A.E. \& Delgado Rodrigues J. (eds.) The gardens of the National Palace of Queluz: conservation intervention. Associação World Monuments Fund Portugal and World Monuments Fund, p. 81-89.

Doehne E. \& Price C.A. 2010. Stone Conservation - An overview of current research. Research in conservation. Los Angeles, The Getty Conservation Institute, $160 \mathrm{p}$.

English Heritage. 1999. Graffiti on historic buildings and monuments. Methods of removal and prevention. Technical advice note. London, English Heritage, 12 p.

Ferreira Pinto A.P. \& Delgado Rodrigues J. 2008. Stone consolidation: the role of treatment procedures. Journal of Cultural Heritage, 9:38-53.

Grissom C.A., Charola A.E., Boulton A., Mecklenburg M.F. 1999. Evaluation over time of an ethyl silicate consolidant applied to ancient lime plaster. Studies in Conservation, 44(2):113120.

Grossi C.M., Alonso F.J., Esbert R.M., Rojo A. 2007. Effect of Laser Cleaning on Granite Color. Color Research and Application, 32(2):152-159.

Grossi D. 2016. Avaliação da aplicação de consolidantes no Arenito Itararé, constituinte da fachada do Teatro Municipal de São Paulo. Tese de Doutoramento, Instituto de Geociências, Universidade de São Paulo (IGc-USP), 242 p.

Hansen E., Doehne E., Fidler J., Larson J., Martin B., Matteini M., Rodriguez-Navarro C., Pardo E.S., Price C., Tagle A., Teutonico J.M., Weiss N. 2003. A review of selected inorganic consolidants and protective treatments for porous calcareous materials. Reviews in Conservation, (4):13-25.

Honeyborne D., Ashurst J., Price C., Ross K. 1990. Surface treatments. In: Ashurst J. \& Dimes F.G. (eds.) Conservation of building \& decorative stone. Grã-Bretanha, Butterworth Heinemann, Part 2:155-184.

ICOMOS - International Council on Monuments and Sites. 1964. Carta de Veneza - Carta internacional sobre a conservação e o restauro de monumentos e sítios.

IPPAR - Instituto Português do Património Arquitectónico. 2006. Mosteiro dos Jerónimos - a intervenção de conservação do claustro. Lisboa, IPPAR/Ministério da Cultura, World Monuments Fund, $303 \mathrm{p}$.

Kumar R. \& Kumar A.V. 1999. Biodeterioration of stone in tropical environments. An overview. Los Angeles, The Getty Conservation Institute, $95 \mathrm{p}$.

Macchia A., Ruffolo S.A., Rivaroli L., La Russa M.F. 2016. The treatment of iron-stained marble: towards a "green" solution. International Journal of Conservation Science, 7(n. esp. 1):323-332.

Normandin K.C. \& Slaton D. 2005. Cleaning Techniques in Conservation Practice. A special issue of the Journal of Architectural Conservation. Great Britain, Donhead, $146 \mathrm{p}$. 
Normandin K.C. \& Slaton D. 2006. Cleaning techniques. In: Henry A. (ed). Stone Conservation. Shaftesbury, Donhead, p. 127-160.

Price C.A. 2006. Consolidation. In: Henry A. (ed). Stone Conservation. Shaftesbury, Donhead, p. 101-126.

Revez M.J. \& Delgado Rodrigues J. 2016. Incompatibility risk assessment procedure for the cleaning of built heritage. Journal of Cultural Heritage, 18:219-228.

Sabatini G., Giamello M., Pini R., Siano S., Salimbeni R. 2000. Laser cleaning methodologies for stone façades and monuments: laboratory analyses on lithotypes of Siena architecture. Journal of Cultural Heritage, 1:S9-S19.

Salimbeni R., Pini R., Sian S., Calcagno G. 2000. Assessment of the state of conservation of stone artworks after laser cleaning: comparison with conventional cleaning results on a twodecade follow up. Journal of Cultural Heritage, 1:385-391.

Sassoni E., Naidu S., Scherer G.W. 2011. The use of hydroxyapatite as a new inorganic consolidant for damaged carbonate stones. Journal of Cultural Heritage, 12:346-355.

Sassoni E., Franzoni E., Pigino B., Scherer G.W., Naidu S. 2013. Consolidation of calcareous and siliceous sandstones by hydroxyapatite: comparison with a TEOS-based consolidant. Journal of Cultural Heritage, 14S:e103-e108.

Scherer G.W. \& Jiménez-González I. 2008. Swelling clays and salt crystallization: damage mechanisms and the role of consolidants. In: Delgado Rodrigues J. \& Mimoso J.M. (eds.) International Symposium Stone Consolidation in Cultural Heritage - research and practice, Proceedings, Lisbon, LNEC, p. 29-39.

Snethlage R. \& Wendler E. 1991. Surfactants and adherent silicon resins - New protective agents for natural stone. In: Symposium in Materials Research Society. Pittsburgh, Proceedings, v. 185, p. 193-200.

Snethlage R., Gruber C., Tucic V., Wendler E. 2008. Transforming gypsum into calcium phosphate - the better way to preserve lime paint layers on natural stone? In: Delgado Rodrigues J. \& Mimoso J.M. (eds.) International Symposium Stone Consolidation in Cultural Heritage - research and practice, Proceedings, Lisbon, LNEC, p. 1-13.

Wangler T. \& Scherer G.W. 2009. Clay swelling inhibition of $\alpha, \omega$-diaminoalkanes in Portland Brownstone. Journal Material Research, 24(5):1646-1652.

Webster G.M. (ed.). 1992. Stone cleaning and the nature, soiling and decay mechanisms of stone. Great Britain, Donhead, 308 p.

Wheeler G. 2005. Alkoxysilanes and the consolidation of stone. Research in conservation. Los Angeles, The Getty Conservation Institute, 196 p. Disponível em: http://www.getty.edu/conservation/publications_resources/pdf_publications/pdf/alkoxysilanes_vl.p df. 


\section{Geoconservação: aspectos educacionais e divulgação das geociências}

A divulgação científica é uma atividade que requer não só o domínio do próprio conhecimento científico mas também o domínio de uma estratégia de se apresentar temas que, mesmo não palatáveis ao público em geral, tenham a capacidade de lhes despertar a atenção e interesse. No campo geocientífico, alguns temas naturalmente têm maior receptividade, por exemplo vulcões, terremotos, dinossauros e minerais.

O turismo geológico, com base nas ciências da terra, que atualmente é praticado com a denominação geoturismo, tem sido uma forma de divulgação e disseminação do conhecimento geocientífico, além de contribuir para a preservação do patrimônio geológico, e que tem mostrado resultados de certa forma satisfatórios. Atualmente as formas mais efetivas de divulgação sem dúvida é a Internet e a televisão, que atingem grande parte do público, independentemente da faixa etária. Desta forma, a elaboração de roteiros geoturísticos pode ser uma grande ferramenta de disseminação do conhecimento geocientífico.

A divulgação das geociências com base nos roteiros geoturísticos propostos para os centros urbanos recebeu a denominação geoturismo urbano. Adicionalmente, foram criados ramos de geoturismo associados a cemitérios (denominados Geologia e Geoturismo Cemiterial) e igrejas (Geologia e Geoturismo Eclesiástico), sendo esses locais onde são encontrados tanto túmulos e esculturas em pedra, pisos e revestimentos pétreos, geralmente com uma grande geodiversidade que incluem materiais pétreos tanto provenientes do país quanto do exterior, o que justifica a visitação sob o ponto de vista geológico a esses locais.

O Brasil, devido à sua extensão territorial, sua geodiversidade, e sua evolução geológica desde o Arqueano, é um país com muitas opções para o Geoturismo, contando com diversos locais que constam em listas de entidades nacionais e internacionais com atrativos geoturísticos: 20 inscrições na lista do patrimônio mundial da Unesco (13 culturais e 7 naturais), Geoparque Araripe (Chapada Araripe, Ceará), parques naturais, antigas pedreiras transformadas em parques, entre outras atrações. A elaboração de roteiros geoturísticos tem, 
de uma certa forma, propiciado a educação geocientífica para público leigo e recurso didático para os geocientistas.

Iniciativas e programas no Rio de Janeiro, tais como os projetos Caminhos Geológicos (DRM - Departamento de Recursos Minerais do estado do Rio de Janeiro) e Caminhos de Darwin (Mansur 2009a e 2009b, respectivamente) auxiliam na popularização das geociências, tendo os projetos educacionais em Ciências da Terra o seu difusor (Piranha et al. 2011), além da importância dos museus nesta tarefa (Del Lama 2015).

O Museu de Geociências do IGc-USP, que possui um dos maiores acervos de materiais geológicos do Brasil, recebe visita de alunos de toda rede de ensino, além do público em geral, desenvolvendo um constante trabalho de divulgação das geociências. Azevedo \& Del Lama (2015) discutem a exposição deste museu, além de descreverem comparativamente diversos museus nacionais e internacionais que promovem a difusão dos conceitos geocientíficos.

Também no IGc-USP, foi criado em 2011, o Núcleo de Apoio à Pesquisa (NAP) denominado Geohereditas - Patrimônio Geológico e Geoturismo, que consolidou a temática da Geoconservação nesta unidade de ensino e pesquisa da Universidade de São Paulo, colaborando ativamente em projetos educacionais (Garcia 2015).

Uma outra abordagem sob a ótica da educação formal, foi a edição do e-book Geociências e Educação Ambiental (Bacci 2015) que discute o ensino de Ciência do Sistema Terra entremeado por questões socioambientais e geoconservacionistas, e salienta a oportunidade e importância do curso de Licenciatura em Geociências e Educação Ambiental do IGc-USP para a educação geocientífica, e consequentemente para a divulgação das geociências.

No exterior, merecem destaques programas, organizações e museus que se ocupam da disseminação das ciências e a conservação do patrimônio, além de diversos programas de TV, como por exemplo da rede BBC (British Broadcasting Channel) de Londres.

A Rede de Centros Ciência Viva de Portugal foi criada em 1996 e é constituída hoje por 20 centros, constituídos por espaços interativos de divulgação científica com base no desenvolvimento regional (científico, cultural e econômico) que objetiva promover a cultura científica e tecnológica no país. A rede é caracterizada pela diversidade, pois os centros são temáticos e multidisciplinares. Na Figura 8.1 e nos próximos parágrafos são exemplificados dois desses centros.

O Centro de Ciência Viva do Lousal é referência em patrimônio mineiro. A mina do Lousal operou de 1900 até 1988, explorando o enxofre da pirita, e secundariamente ouro, cobre e zinco. Hoje, as instalações remetem o visitante a voltar no tempo em que a mina era ativa.

O Centro de Ciência Viva de Estremoz foca no Planeta Terra, abordando inúmeros conceitos geocientíficos como minerais, ciclo das rochas, ciclo hidrológico, tectônica, recursos energéticos, tempo geológico, entre outros. Em Estremoz foi construída uma representação de um sistema solar na escala 1:414.000.000, em que a distribuição dos planetas e satélites abrangem tanto a área da cidade quanto os seus arredores.

Outras iniciativas em Portugal incluem o Roteiro das Minas e Pontos de Interesse Mineiro e Geológico de Portugal, com destaque para o Trilho Geológico no Jardim Público em Beja, o Museu do Mármore em Vila Viçosa, o Museu Nacional de História Natural em Lisboa, o Museu 
do Quartzo em Viseu, o Geopark Arouca, os Pontos geológicos da foz do Douro no Porto, o Museu da Pedra em Alpendorada, além dos centros de Ciência Viva já citados.

Na República Tcheca, o Museu Vltavínu em Cesky Krumlov é referente à moldavita (Figura 8.2). Trata-se de produto de impacto de meteorito e tem valor gemológico, tipicamente ocorrendo nesta região. Apesar do museu estar situado na República Tcheca, a moldavita está relacionada à cratera de impacto Ries Crater, na Alemanha (Figura 2.26D).

Existem duas crateras de impacto habitadas no mundo, a já citada Ries Crater e a Cratera de Colônia, na região sul da cidade de São Paulo (Velázquez et al. 2016).
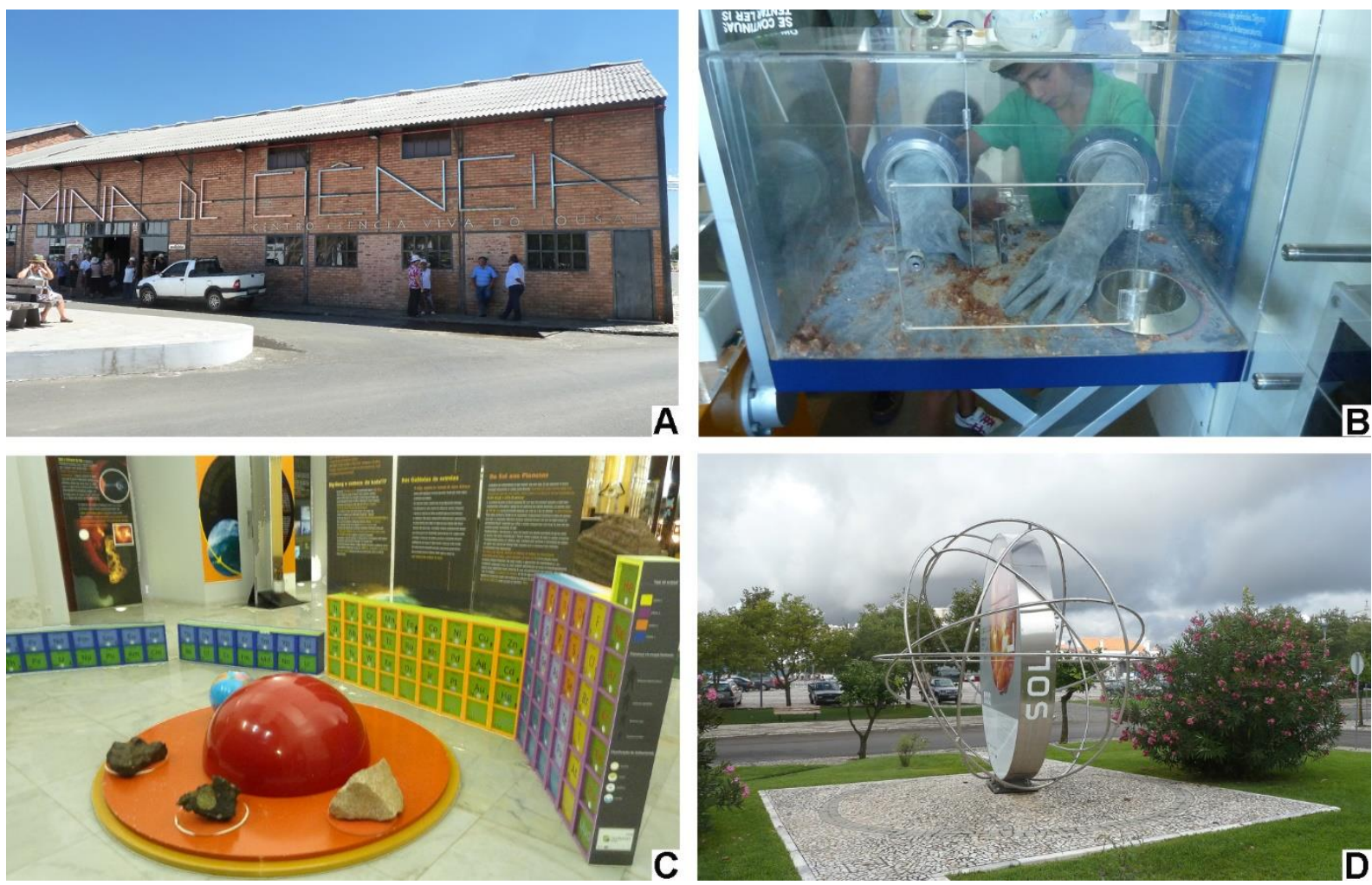

Figura 8.1. Exemplos da Rede de Centros Ciência Viva de Portugal. A e B. Centro de Ciência Viva do Lousal. C. Centro de Ciência Viva de Estremoz. D. Sistema Solar em Estremoz, onde o sol está "localizado" na praça central da cidade.
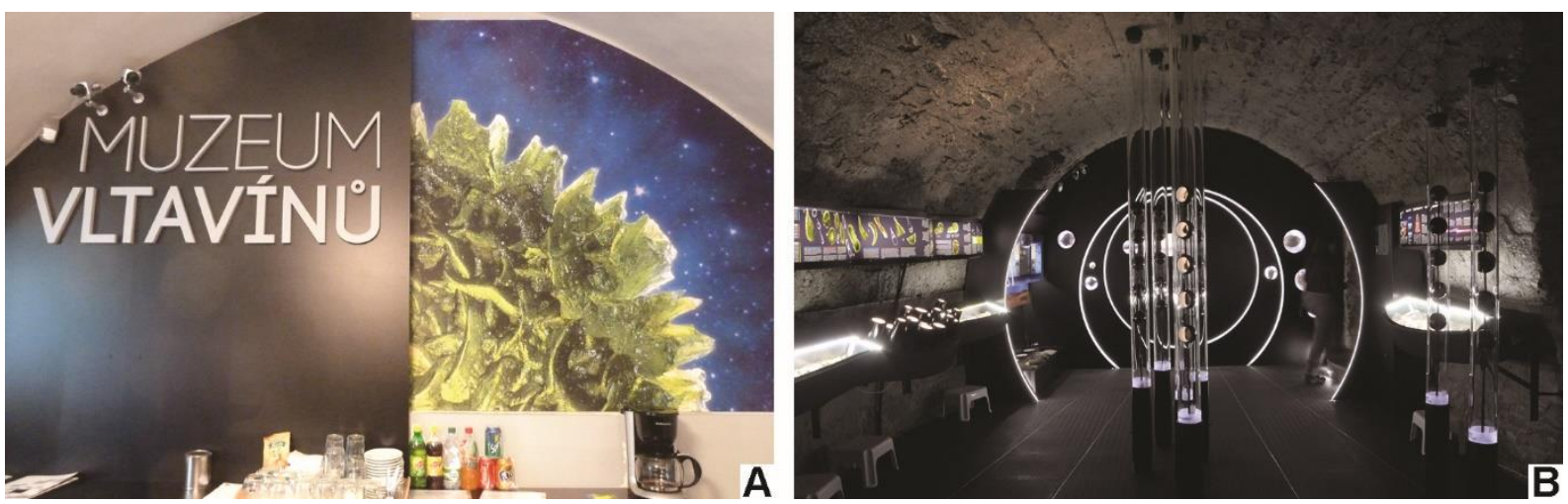

Figura 8.2. A e B. Museu Vltavínu, temático sobre moldavita, Cesky Krumlov, Rep. Tcheca. Fotografias: Lauro K. Dehira. 


\subsection{Geoturismo urbano}

A denominação Geoturismo Urbano é relativamente recente, mas a sua prática tem sido feita já há décadas. Desde os trabalhos de Eric Robinson $(1984,1985)$ para público leigo na Inglaterra, ou então os itinerários pedagógicos para o ensino médio na Espanha nos anos de 1980 (Anguita-Virella 1982), a publicação de trabalhos e guias geoturísticos urbanos tem aumentado.

Geoturismo Urbano é considerado aqui como turismo praticado em lugares visitáveis em qualquer parte do perímetro urbano, seja na forma de patrimônio edificado, seja na forma de afloramentos de rocha, e que esteja relacionado com conceitos geológicos (Del Lama 2017). A autora discute o tema e indica referências de roteiros geológicos na Inglaterra, Espanha, França, Itália, Portugal, Canadá, México e Brasil, e apresenta a área do centro da cidade de São Paulo como estudo de caso.

Liccardo et al. (2012) apontam o geoturismo urbano como agente multiplicador eficaz da difusão geocientífica, devido à rapidez e eficiência que o conhecimento chega às pessoas, podendo tornar-se uma conexão com o geoturismo de áreas naturais.

Algumas cidades brasileiras já contam com roteiros geológicos disponíveis, fornecendo descrições geocientíficas para uma ampla gama de público. Exemplos destes roteiros são encontrados em: Curitiba, Rio de Janeiro, Natal, Santos e Salvador (Liccardo et al. 2008, Mansur et al. 2008, Carvalho 2010, Mantesso-Neto et al. 2012 e Pinto 2015; respectivamente).

Um roteiro mais especializado é proposto por Mucivuna et al. (2015) focando as fortificações militares da Baixada Santista.

Arruda (2013) trata do patrimônio construído no Litoral Norte do Estado de São Paulo.

Especificamente para a cidade de São Paulo, os roteiros e trabalhos sobre geoturismo disponíveis são Stern et al. (2006), Reys et al. (2008), Augusto \& Del Lama (2011), Rodrigues (2012), Kanke (2013), Del Lama et al. (2015) e Del Lama (2017).

Em Curitiba, Liccardo (2010) aponta que é bastante comum nos monumentos da cidade o granito cinza-rosado da Serra do Mar proveniente do município de Quatro Barras. O calçamento do centro, feito na forma de petit-pavé (mais conhecido como calçada portuguesa), é constituído por mármore dolomítico e diabásio de Almirante Tamandaré. Já nas Ruínas de São Francisco, acredita-se que foram utilizados metagranitoides do embasamento de Curitiba.

O patrimônio geológico do estado de São Paulo é caracterizado por Mantesso-Neto et al. (2013) com forte viés ao patrimônio natural, destacando o Projeto Monumentos Geológicos de São Paulo, as cavernas da província cárstica do Vale do Ribeira, o conjunto de formas e exposições de rocha do litoral, o patrimônio construído e o patrimônio mineiro das minas abandonadas no Vale do Ribeira, Guarulhos e arredores do Pico do Jaraguá, mencionando também a Real Fábrica de Ferro de São João de Ipanema.

A cidade de São Paulo conta com inúmeros monumentos e edifícios confeccionados em pedra, principalmente no centro velho, que até o começo do século XX era apenas um pequeno núcleo urbano. Apenas após a riqueza trazida pelo café que a cidade de São Paulo transforma-se numa cidade moderna. Apesar de muitas das rochas utilizadas na confecção 
dos edifícios e monumentos serem importadas, principalmente da Itália e de Portugal, as rochas que revestem os edifícios e monumentos do centro velho são brasileiras, particularmente do próprio estado de São Paulo. Entre estas, destacam-se o Granito Itaquera e o Granito Cinza Mauá, o primeiro mais utilizado no começo do século passado e o segundo, a partir da década de 40 desse mesmo século (Del Lama et al. 2009).

Em um percurso pelos principais edifícios e monumentos históricos que compõem o denominado Centro Velho de São Paulo podem ser visualizadas as seguintes rochas, tanto nacionais quanto importadas: Granito Itaquera, Granito Cinza Mauá, Granito Rosa Itupeva, Granito Verde Ubatuba, Granito Preto Piracaia, Granito Salto, Granito Vermelho Bragança, Granito Vermelho Capão Bonito, Granito Azul Bahia, Granito Ás de Paus, Larvikito, Granito Preto São Gabriel, Calcário Sete Lagoas, Calcário Lioz e outros calcários fossilíferos, Arenito Itararé, Arenito Botucatu, Travertino Romano, conglomerado, Metacalcário com Estromatólitos, Mármore Carrara e outros mármores, e serpentinito (Figura 8.3).

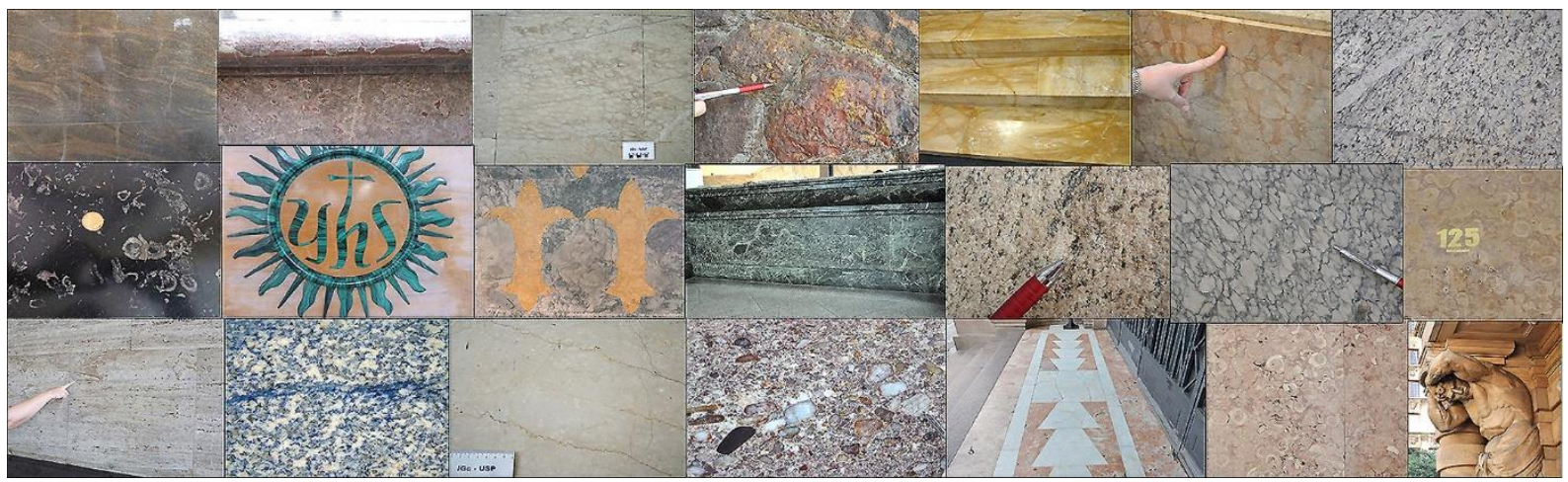

Figura 8.3. Marca-página do NAP Geohereditas divulgando geoturismo urbano em São Paulo. Mosaico de pedras ornamentais encontradas em edifícios do centro velho.

Exemplos dessas edificações e monumentos no centro velho de São Paulo podem ser encontradas no site do NAP Geohereditas (http://www.igc.usp.br/index.php?id=geohereditas) e as descrições dessas rochas podem ser obtidas em Del Lama et al. (2015).

O roteiro apresentado em Del Lama et al. (2015) trata apenas de ambientes exteriores, e o interessado na visitação desses locais internamente deve se atentar a horários de abertura do serviço público e/ou ao agendamento de visitas guiadas. A seguir são apresentadas algumas informações de interiores desse roteiro para auxiliar na visitação.

No Teatro Municipal, além do revestimento na fachada frontal de Arenito Itararé e embasamento de Granito Itaquera, as colunas do piso superior são constituídas pelo Granito Rosa Itupeva. No interior, além dos mármores italianos, como o Rosso Verona (Figura 8.4A), as colunas no hall de entrada são de Granito Itaquera e, na parte superior, é observado o Mármore Itupararanga (Figura 8.4B), proveniente da fazenda homônima, que ocorre próximo a cidade de Ibiúna. A fazenda era de propriedade de Ramos de Azevedo, que a adquiriu em 1890, para fornecer esta rocha e cal virgem para suas obras (Bueno 2015). 
No Edifício Alexandre Mackenzie, hoje Shopping Light, situado em um dos lados do Viaduto do Chá, observa-se um revestimento de parede constituído de um degradê de rochas verdes. A pedra branca com esta venulação esverdeada é muito semelhante ao Mármore Campan Vert, oriundo dos Pirineus (Figura 8.4C).

No Edifício Matarazzo (também conhecido informalmente como Banespinha), sede da Prefeitura Municipal, seu hall interior é revestido com Travertino Romano assim como seu exterior, mas encontra-se recoberto por uma camada de resina ou verniz, o que provoca alteração na sua cor natural. Os balcões são revestidos por um calcário fossilífero preto (Figura 8.4D).
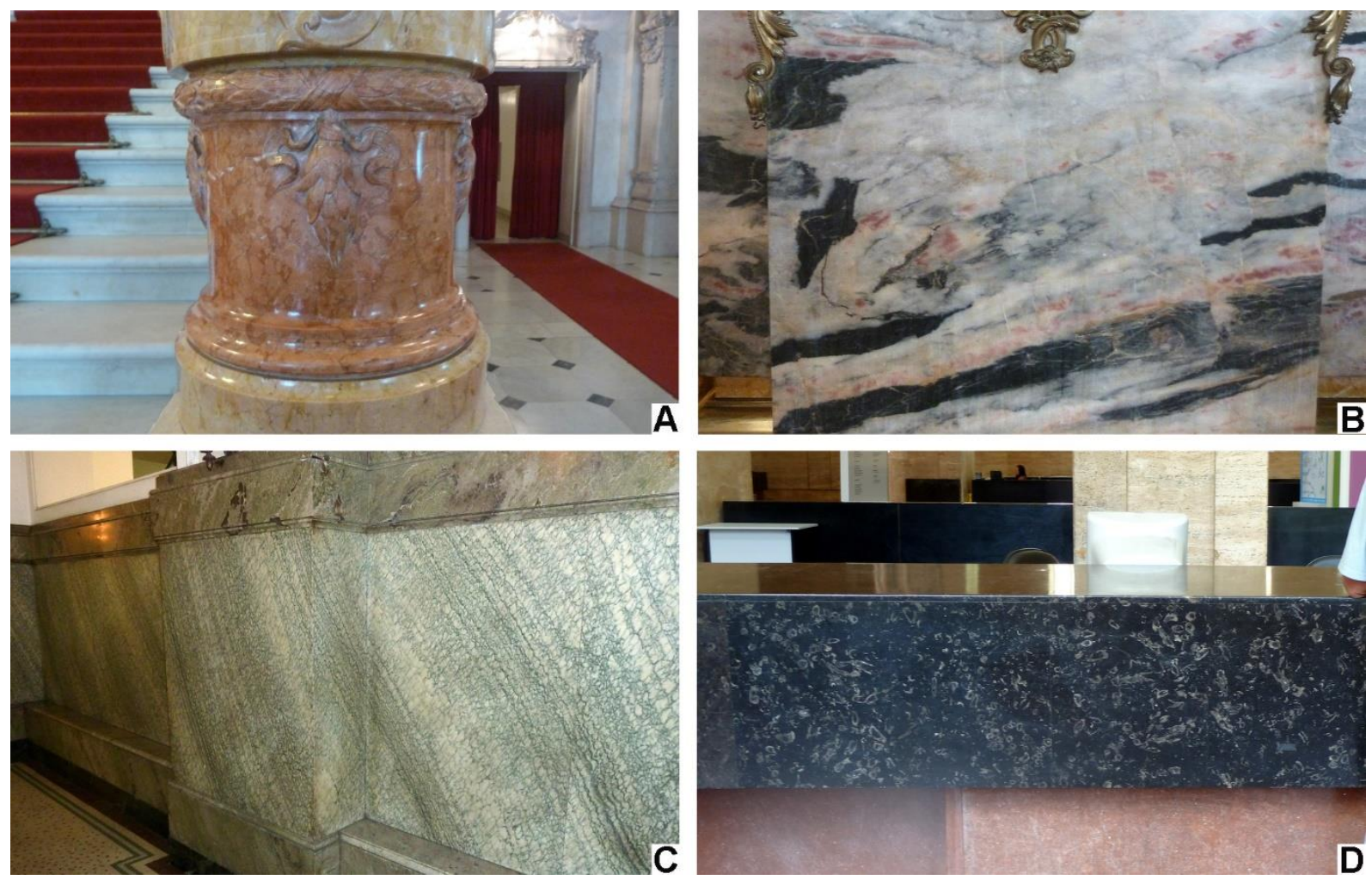

Figura 8.4. Pedras ornamentais no centro velho de São Paulo. A. Rosso Verona no Teatro Municipal. B. Mármore Itupararanga no Teatro Municipal. C. Mármore Campan Vert no Shopping Light. D. Calcário fossilífero na Prefeitura.

Na Praça Antonio Prado, o antigo Banco de São Paulo atualmente abriga a Secretaria de Estado da Juventude, Esportes e Lazer. À parte seu revestimento exterior com Preto Piracaia, o interior apresenta mármores importados.

O Palácio da Justiça tem grande quantidade de revestimentos em mármore de Carrara, mármore amarelo português, granito rosa e ornamentos confeccionados com película de ouro (Suzuki 2015). Externamente o edifício é revestido com Granito Rosa Itupeva.

Dessa forma, constata-se que a cidade de São Paulo apresenta uma grande diversidade de tipos petrográficos nas suas construções, o que justifica a visitação geoturística, principalmente no seu centro velho. 


\subsection{Geologia cemiterial}

Os cemitérios constituem-se em fontes históricas dos aspectos sociais, materiais e arqueológicos de uma população, já que a partir da observação dos tipos de jazigos aí presentes, pode-se analisar e interpretar as mudanças demográficas que ocorreram, as mudanças nos diferentes tipos de formas de arte, atitudes com relação à morte e religião e mesmo os registros da história da população local.

O sepultamento dos mortos sempre foi uma preocupação desde a pré-história, e algumas civilizações fizeram isso com muita propriedade, vide as estruturas megalíticas europeias (Antequera na Espanha, Stonehenge na Inglaterra - Figura 8.5A, Carnac na França, Cremeleque de Almendre - Figura 8.5B e Anta Grande de Zambujeiro em Portugal) e as pirâmides no Egito, entre outras.

O primeiro túmulo conhecido na forma de templo é o Nereid Monument (Figura 8.5C) encontrado em Xanthos, no sudoeste da Turquia, e o maior deles é o Mausoleu de Halicarnasso.

Os romanos dispunham os túmulos em ruas de acesso à cidade, como pode ser observado na Via Ápia ou em Pompeia (Figura 8.5D).
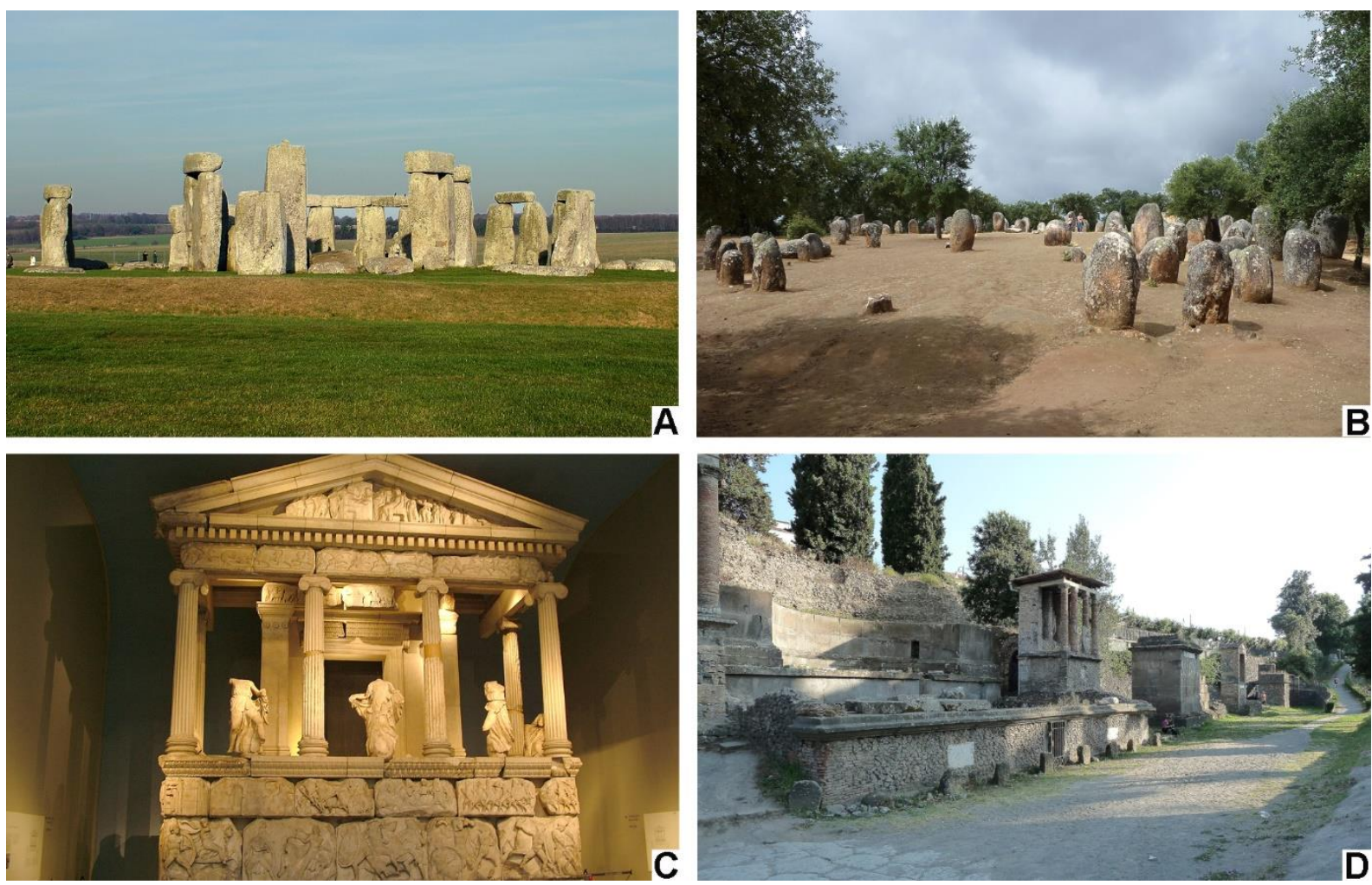

Figura 8.5. Estruturas megalíticas europeias. A. Stonehenge, Inglaterra. B. Cremeleque de Almendre, Évora, Portugal. C. Nereid Monument, reconstruído no British Museum. D. Sítio Arqueológico de Pompeia.

Antigamente os sepultamentos eram realizados em igrejas ou nos seus arredores. Além da superlotação destes espaços, esta forma de sepultamento trazia problemas de saúde devido 
à insalubridade dos corpos ali sepultados, que podiam afetar os frequentadores das igrejas. Ademais, somente à classe alta era permitido o sepultamento dentro das igrejas, e quanto mais importante era o falecido mais próximo ficava do altar. Assim, por razões sanitárias foram criados os cemitérios públicos.

Os cemitérios históricos adjacentes às igrejas, denominados graveyards ou kirkyards (termo escocês), ainda são muito encontrados na Grã-Bretanha (Figura 8.6) e a Historic Scotland fornece orientações para sua conservação (Maxwell et al. 2001).
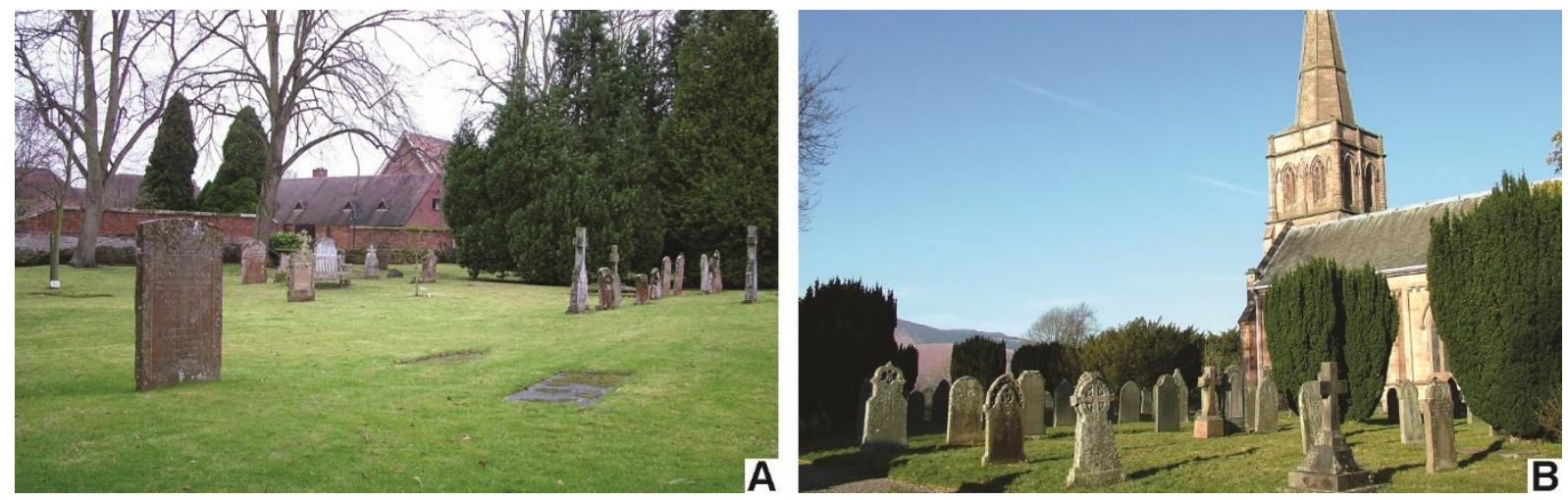

Figura 8.6. Cemitérios adjacentes às igrejas na Grã-Bretanha. A. Holy Trinity Church, Stratford-upon-Avon. Shakespeare está enterrado no interior desta igreja. B. Keswick.

À parte os aspectos sociológicos sobre os cemitérios, apresenta-se a seguir uma abordagem do constituinte material do jazigo: a pedra.

A pedra foi usada em diferentes tipos de jazigos, tais como, laje vertical, placa, sarcófago, caixa, dólmen (mesa de pedra), obelisco (muito comum na era Vitoriana na Inglaterra), e como adornos em variadas esculturas.

Os cemitérios são propícios para se estudar o intemperismo das pedras, já que os túmulos são datados, além da grande diversidade de litotipos lá existente.

Antes do advento do transporte mecanizado, era muito caro transportar grandes quantidades de materiais de construção por grandes distâncias, por isso, em muitas áreas foram utilizados materiais locais (Figura 8.7), muitas vezes adaptando o monumento à pedra disponível. Por outro lado, quando havia disponibilidade de variedade de pedras, podia-se escolher aquela que fosse mais fácil de esculpir.

Apesar de não ter sido tão utilizado como a pedra, também há túmulos em ferro, sendo o ferro fundido e o ferro forjado os tipos mais utilizados. O principal problema deste tipo de material é a corrosão, e para aumentar a vida útil deste material é necessária manutenção mais frequente, inspeção regular e pintura.

Na Escócia, os túmulos de ferro fundido aparecem no final do século XVIII. Uma porção significativa desses túmulos foi removida e reutilizada para a fabricação de munição em guerras (Maxwell et al. 2001). 

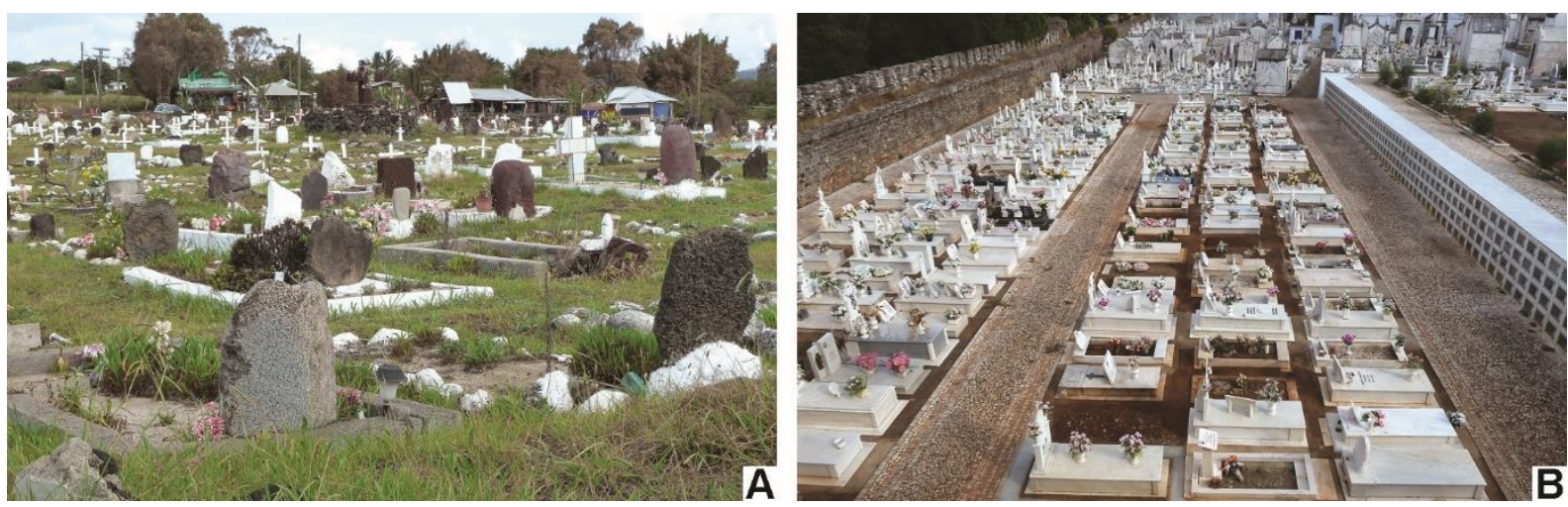

Figura 8.7. Cemitérios com apenas um tipo de pedra. A. Tufo vulcânico na Ilha de Páscoa, Chile. B. Mármore em Vila Viçosa, Portugal.

Os túmulos construídos com o ferro foram aqui destacados devido à sua presença no Cemitério Nossa Senhora da Soledade (Belém - PA) e no Cemitério Protestante na Flona de Ipanema (Iperó - SP). Palácio (2015) analisa os processos de degradação dos ornamentos metálicos dos jazigos do Cemitério Nossa Senhora da Soledade, fazendo um levantamento dos portões e gradis de ferro fundido, forjado e laminado presentes no cemitério.

Os problemas recorrentes na conservação de jazigos são subsidência e acomodação do terreno (devido aos sepultamentos regulares, não compactação adequada da cova do túmulo e o desenvolvimento das raízes de árvores) que prejudica a estabilidade do túmulo, poluição, umidade ascendente, utilização da pedra com orientação estrutural diferente de sua formação (com as camadas na vertical, propiciando a delaminação), excrementos de pássaros, presença de sais, efeitos microclimáticos e também a detalhes arquitetônicos que favoreçam a ocorrência de deterioração diferenciada (Figura 8.8).

Daniels (2006) traça um roteiro para execução de qualquer trabalho de conservação em cemitério, que deve conter um relatório constando a descrição do jazigo, a sua condição de preservação, as recomendações e as especificações do tipo de trabalhos que devam ser executados e as quantidades e custos. Este autor discute vários aspectos de intervenção em jazigos.

O Laboratoire de Recherche des Monuments Historiques francês confeccionou um guia muito simples para auxiliar o público leigo para a conservação de um jazigo, e que está disponível na Internet (LRMH 2011).

No Brasil, dois trabalhos se debruçaram ao estudo de necrópole com o olhar da conservação da pedra.

Kuzmickas (2013) avaliou o estado de conservação de alguns jazigos do Cemitério da Consolação em São Paulo com utilização de métodos não destrutivos, apresentando um sólido referencial bibliográfico e iconográfico. As exemplificações das formas de deterioração contidas no glossário do ICOMOS (2008) foram praticamente todas encontradas nos túmulos do cemitério. A autora conclui que os principais mecanismos de deterioração do cemitério são devidos à natureza litológica, interação de materiais, poluição atmosférica, colonização biológica, condições climáticas, características arquitetônicas, vandalismo, falta de gerenciamento e métodos inadequados de conservação e restauro. 

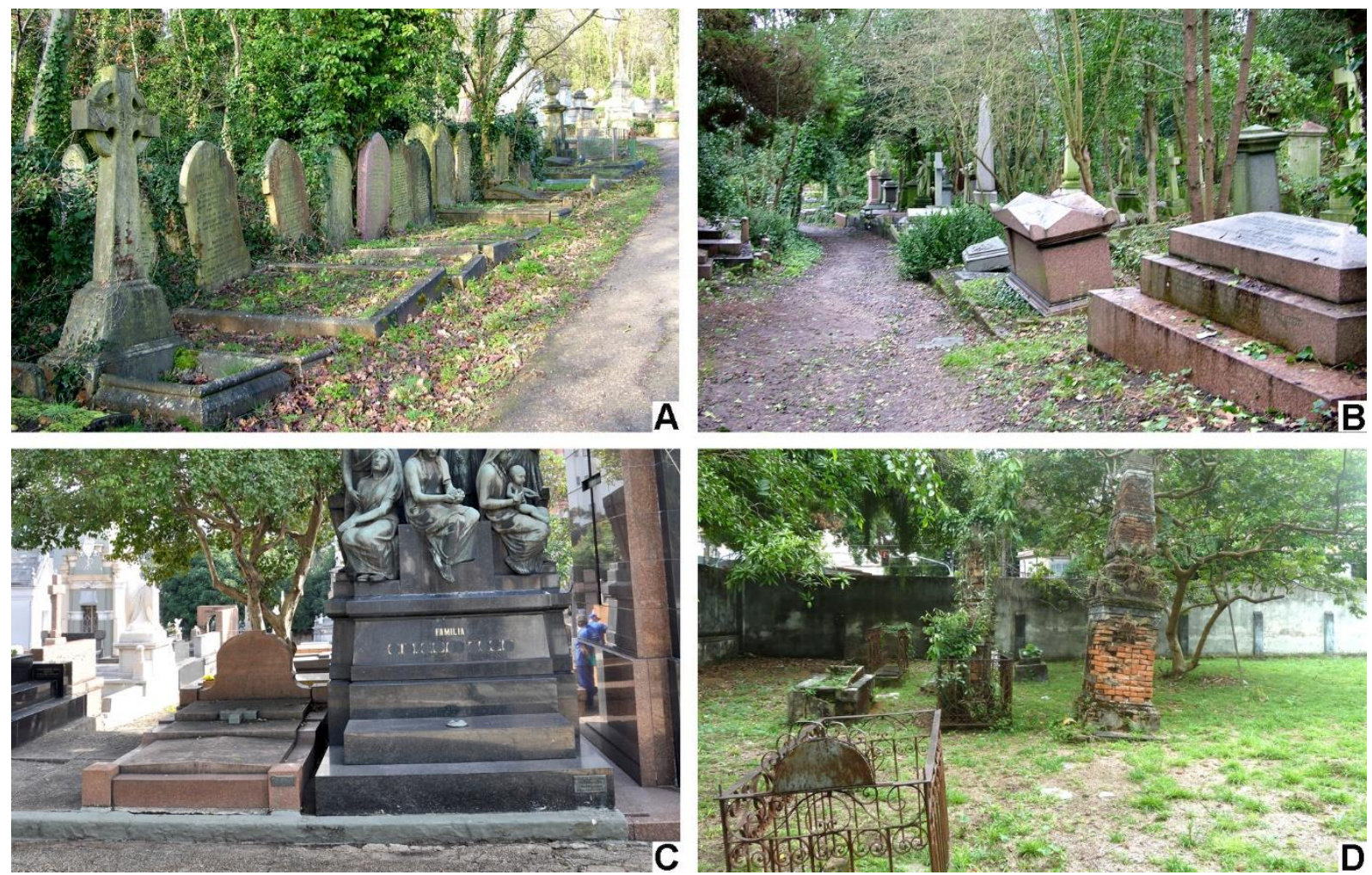

Figura 8.8. Subsidência de jazigos. A e B. Cemitério Highgate, Londres. C. Cemitério da Consolação, São Paulo. D. Cemitério Nossa Senhora da Soledade, Belém.

Silva (2014) analisou o Cemitério Nossa Senhora da Soledade em Belém tombado pelo IPHAN desde 1964 (Figura 8.9). Por meio de análises laboratoriais e técnicas não destrutivas, apresenta subsídios para a conservação do cemitério e sugere a utilização de emplastro de bentonita para a limpeza dos jazigos. O estudo apresenta também o mapeamento dos danos nos túmulos com rico registro fotográfico.

\subsubsection{Geoturismo cemiterial}

Os cemitérios históricos no mundo todo são considerados verdadeiros museus a céu aberto devido ao farto material arquitectônico e de arte das estátuas ali presentes, muitos confeccionados por renomados artistas. O turismo cemiterial é uma atividade já bem consolidada na Europa e nos Estados Unidos. Os interesses para se visitar um cemitério são vários: tranquilidade e lugares arborizados, interesse em arte tumular, curiosidade em conhecer túmulos de pessoas famosas, conhecer os costumes e a evolução da sociedade, reconhecendo o cemitério como um local histórico.

Somado a estes fatores, nas visitações a um cemitério podem ser complementadas as informações sobre a constituição pétrea dos jazigos, conferindo um viés geológico ao turismo tumular. Nesta proposição não se reinventa nada, apenas se acrescenta a informação geológica. 
Nos Estados Unidos, o cemitério mais famoso é o de Arlington (Virgínia, Estados Unidos) onde estão enterrados os veteranos de guerra. Caracteriza-se pelas inúmeras lajes verticais brancas dispostas em um gramado.

La Recoleta, em Buenos Aires, é um dos cemitérios mais visitados da América Latina com muitas estátuas de mármore. O túmulo de Eva Perón está situado neste cemitério.

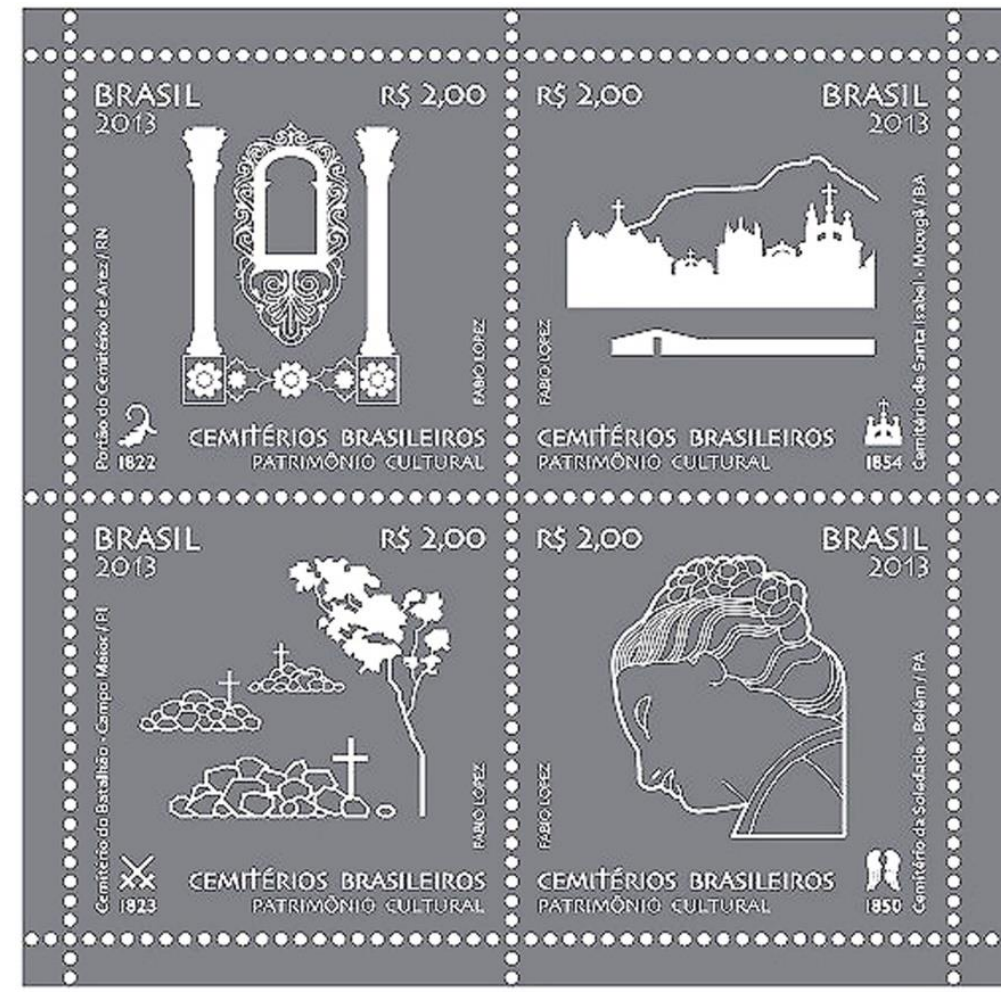

Figura 8.9. Correios homenageiam cemitérios tombados pelo IPHAN na série Cemitérios Brasileiros: Patrimônio Cultural Brasileiro com emissão de selos. Fonte: http://portal.iphan.gov.br/uploads/ .

A Association of Significant Cemeteries in Europe (ASCE) criou em 2009 a Rota dos Cemitérios Europeus para promover os cemitérios como patrimônio cultural. A rota consiste de 59 cemitérios em 45 cidades de 18 países, recebendo aproximadamente 5 milhões de visitantes por ano (ASCE 2011). A seguir são apresentadas breves informação para alguns desses cemitérios.

O Cemitério Acatólico de Roma, monumento nacional desde 1918, também conhecido como Cimitero degli acattolici al Testaccio, Cemitério Protestante e Cemitério dos Poetas e dos Artistas, teve seu primeiro sepultamento em 1738 (Beck-Friis 2010). A maior parte dos túmulos é de pedra, predominando mármore e travertino. Neste cemitério há exemplo de uso de material reciclado em Roma. O túmulo da Figura 8.10A é uma reutilização de material utilizado na época do império.

O Cemitério Père-Lachaise, inaugurado em 1804, é o mais famoso cemitério parisiense, e talvez mundialmente. À parte seus numerosos personagens ilustres aí sepultados, é um santuário para a flora e a fauna. Os túmulos são constituídos por Calcário Lutetiano de Paris, 
Calcário de Champigny, Calcário de Château-Landon, Arenitos de Fontainebleau, Meulière de Brie e Montmorency (rocha silicosa) (Rodrigues 2014). O túmulo de Oscar Wilde foi cercado com vidro, pois a manifestação dos fãs deixava o jazigo com muitas marcas de batom (Figura 4.6F). Há abundância de umidade e musgos nos jazigos. Neste cemitério encontra-se um dos primeiros e mais conhecidos jazigos-capelas: Capela Sepulcral da Família Greffulhe, de 1815. É um cemitério muito bem cuidado (Figura 8.10B).

$\mathrm{Na}$ cidade do Porto, existem dois cemitérios históricos, o Cemitério Prado do Repouso, o primeiro cemitério público da cidade, inaugurado em 1839, e o Cemitério Agromonte, inaugurado em 1855. No Cemitério Prado do Repouso há muitas capelas em granito alterado, pedra que predomina nos jazigos (Figura $8.10 \mathrm{C}$ ). Às vezes, o contorno é constituído pelo granito, e a sua parte frontal sendo de Lioz, pedra que aparece em segundo lugar em frequência. Os túmulos mais novos apresentam maior diversidade de litotipos. É frequente a ocorrência de recalques no terreno afetando os túmulos.

O Cemitério Central de Viena, inaugurado em 1874, é o segundo maior da Europa, e só perde em área para o de Hamburgo, mas é o maior em termos de sepultamento. Localiza-se adjacente aos limites da cidade. Abriga o panteão da música clássica com os túmulos de Beethoven, Mozart, Brahms e Strauss. A grande parte dos jazigos são mais ou menos padronizados, predominando granito preto ou cinza (Figura 8.10D), com presença de larvikito e travertino. A base é quase sempre de concreto e poucos apresentam ornamentos de bronze. É um cemitério muito bem conservado, com exceção de alguns túmulos aparentemente abandonados, sem qualquer conservação.
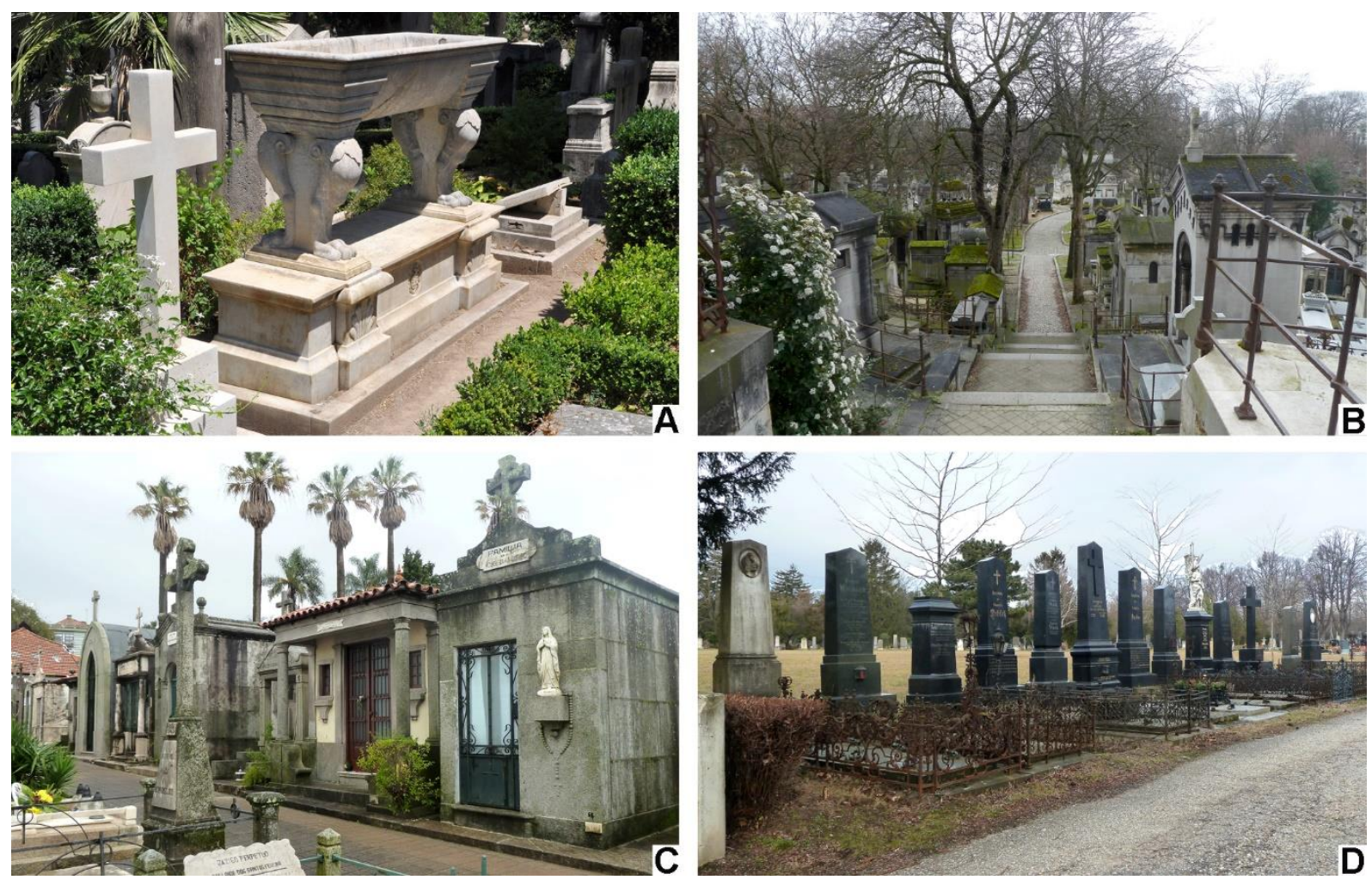

Figura 8.10. Cemitérios da Rota dos Cemitérios Europeus. A. Cemitério Acatólico de Roma, Itália. B. Cemitério PèreLachaise, Paris, França. C. Cemitério Prado do Repouso, Porto, Portugal. D. Cemitério Central de Viena, Áustria. Fotografias A e B: Lauro K. Dehira. 
Não fazendo parte da Rota dos Cemitérios Europeus, mas igualmente históricos, destacamse aqui o Cemitério dos Prazeres em Lisboa e o Highgate em Londres.

O Cemitério dos Prazeres, inaugurado em 1833, possui placa indicativa na entrada explicando a simbologia encontrada em túmulos selecionados e informações em QR Code em alguns túmulos. A grande maioria dos túmulos é constituída por Calcário Lioz (Figuras 8.11A e B).

O Cemitério Highgate (Figura 8.11C), inaugurado em 1839, destaca-se por seus monumentos em estilo vitoriano. Na Seção Oeste há o Círculo de Líbano e as catacumbas egípcias que ajudam a perpetuar a sua fama de mal-assombrado. A Seção Leste é a mais nova e onde está sepultado Karl Marx.

Na categoria de monumentos funerários, destacam-se aqui o Taj Mahal, em Agra, construído em Mármore de Makrana no século XVII, com incrustações de pedras preciosas (lápis-lazúli, turquesa, quartzo, jaspe, jade, safira, e mais 22 outros tipos); e o túmulo de Napoleão Bonaparte, em Paris, construído no século XIX, com o sarcófago em Quartzito Aventurina Vermelho da Finlândia em base de Granito Verde de Vosges (Figura 8.11D).
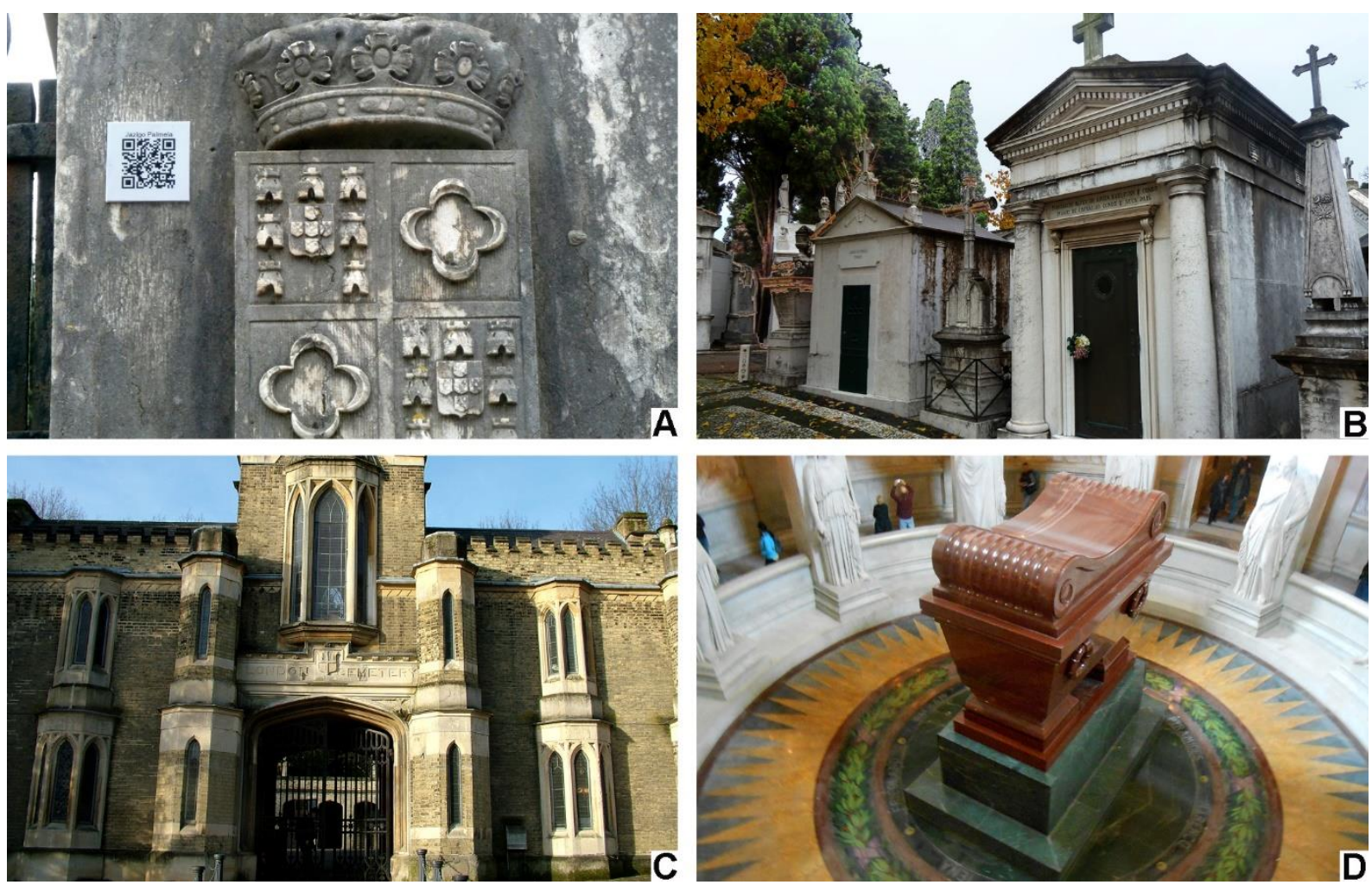

Figura 8.11. A e B. Cemitério dos Prazeres, Lisboa, Portugal. C. Cemitério Highgate, Londres, Inglaterra. D. Túmulo de Napoleão Bonaparte, Hôtel des Invalides, Paris, França. Fotografia D: Juliana M. Del Lama.

No Brasil, a tradição de visitar cemitério com enfoque turístico ainda não está enraizada, mas aos poucos mais pessoas se interessam pelo assunto, sendo que alguns poucos cemitérios já dispõe de visita guiada, mas sem enfoque geológico. 
Entretanto, alguns cemitérios já contam com roteiros geoturísticos disponíveis, como o Cemitério São Paulo (Rodrigues 2014) e o Cemitério da Consolação (Kuzmickas \& Del Lama 2015), ambos na cidade de São Paulo, e o Cemitério de Curitiba (Licardo \& Grassi 2014).

Os catálogos estatuários do final do século XIX/início do século XX usados na Europa também foram usados no Brasil, o que gera uma certa semelhança de formas das estátuas nos diversos cemitérios antigos.

Ribeiro (1999) discute a influência dos marmoristas italianos na arte tumular paulistana, com rico registro fotográfico de esculturas dos cemitérios paulistanos.

Inaugurado em 1852 por D. Pedro II, no Cemitério São João Batista no Rio de Janeiro é possível observar a evolução arquitetônica das sepulturas, do estilo eclético e neogótico do fim do século XIX e início do XX, ao estilo art déco entre as guerras mundiais. Uma curiosidade de cunho geológico deste cemitério é que Orville Derby (1851-1915), fundador do Serviço Geológico no Brasil, está sepultado neste cemitério (Figura 8.12) e seu túmulo é ornamentado por uma escultura de mármore de Carrara confeccionada por Rodolfo Bernardelli (autor do túmulo do ex-presidente Campos Salles no Cemitério da Consolação em São Paulo, dentre muitos outros). Segundo o site do cemitério, esta foi a primeira obra abstrata feita no Brasil. Desde 2015 foram instalados códigos QR Code em túmulos de personagens famosas e as visitas ocorrem mensalmente.

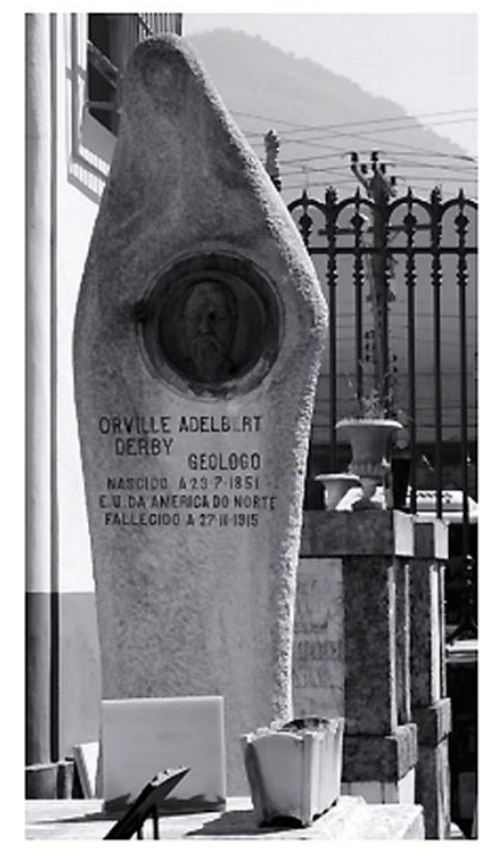

Figura 8.12. Túmulo de Orville Derby, Cemitério São João Batista, Rio de Janeiro. Fonte: http://www.artefunerariabrasil.com.br/admin/upload/artigos/artigo\%20revista\%20locus,2013.pdf.

O Cemitério da Consolação, fundado em 1858, foi o primeiro cemitério municipal criado na cidade de São Paulo. Apesar de que em seu início ocorriam sepultamentos de pessoas de todas as classes sociais, no início do século XX passa a servir só as classes econômicas mais abastadas. Concebido em uma época de profundas mudanças, tornou-se o testemunho da história da monarquia e da república brasileira, assim como da elite cafeicultora paulista. 
O Cemitério da Consolação tem jazigos constituídos por litotipos de diferentes origens (rochas sedimentares, ígneas e metamórficas), destacando-se: travertino, calcário fossilífero, arenito, granito (Itaquera, Cinza Mauá, Vermelho Bragança, Vermelho Capão Bonito), monzonito (Preto Piracaia, Preto Bragança), gabro (Preto Apiaí), sienito, charnockito (Verde Ubatuba), mármore (branco, rosa, cinza), ardósia e gnaisse, que apresentam variações estruturais, texturais e mineralógicas (Figura 8.13A).

Esse cemitério constitui-se em uma referência impar em arte tumular, com o Granito Itaquera já aparecendo no portal de entrada, projetado por Ramos de Azevedo, e dando as boas vindas aos visitantes (Figura 8.13B). Além da visita guiada, que ocorre duas vezes por semana, há um folder com indicações dos túmulos de personalidades ilustres e obras de renomados escultores, que pode ser obtido pela internet no site da prefeitura de São Paulo.

Deve ser mencionado que o Cemitério da Consolação foi um dos primeiros cemitérios brasileiros a ter visita guiada, e isso deve-se a Délio Freire dos Santos (Figura 8.13C), antigo administrador e estudioso do tema, e que teve seu discípulo em Francivaldo Gomes, o Popó, que é quem realiza atualmente as visitas guiadas. Seria interessante do ponto de vista geológico que fossem adicionadas no tour já existente, informações dos litotipos dos jazigos, o que favoreceria a divulgação científica. Além da visita guiada instituída, desde 2015 foram instalados informações em QR Codes em alguns túmulos.

O Cemitério do Araçá (Figuras 8.14A e B), também em São Paulo, foi construído em 1887. Os principais litotipos encontrados nos jazigos são: mármore branco, granitos Preto Bragança, Salto, Preto Piracaia, Cinza Mauá, Vermelho Capão Bonito, Vermelho Bragança, Itu, Preto São Gabriel, Rosa Itupeva, Marrom São Paulo, Itaquera, charnockito, travertino, Bege Bahia, Calcário Lioz e Pedra de São Tomé. Vargas (2015) aponta que o litotipo predominante na via principal do cemitério que dá acesso ao prédio do Serviço Funerário é o mármore branco, seguido dos granitos Preto Bragança, Salto e Preto Piracaia.

O Cemitério São Paulo (Figuras 8.14C e D), em São Paulo, inaugurado em 1926, tem predomínio de túmulos constituídos pelos granitos vermelhos (Bragança, Salto e Itu) e Preto Piracaia. Também são comuns o Granito Cinza Mauá, charnockito e travertino.

Na cidade de São Paulo, além dos cemitérios históricos (Consolação, Araçá, São Paulo), há os monumentos funerários, tais como, o Monumento à Independência e o Obelisco do Ibirapuera.

O Monumento à Independência do Brasil, inaugurado em 1922, foi realizado por Ettore Ximenes e Manfredo Manfredi. A cripta imperial, localizada sob o monumento, foi inaugurada somente em 1952, e abriga os restos mortais de D. Pedro I e suas duas esposas, as imperatrizes D. Leopoldina de Habsburgo e D. Amélia de Leuchtenberg. O monumento é constituído por granito cinza e com esculturas de bronze.

O Obelisco do Ibirapuera, também conhecido como Obelisco Mausoléu aos Heróis de 32 , construído entre 1947 e 1970, foi projetado por Galileo Emendabili e é o maior monumento da cidade com $72 \mathrm{~m}$ de altura, sendo constituído pelo Travertino Romano. Apresenta o interior revestido também com Travertino Romano e Mármore Carrara, além das capelas com paredes feitas com pastilhas de mosaico veneziano. 

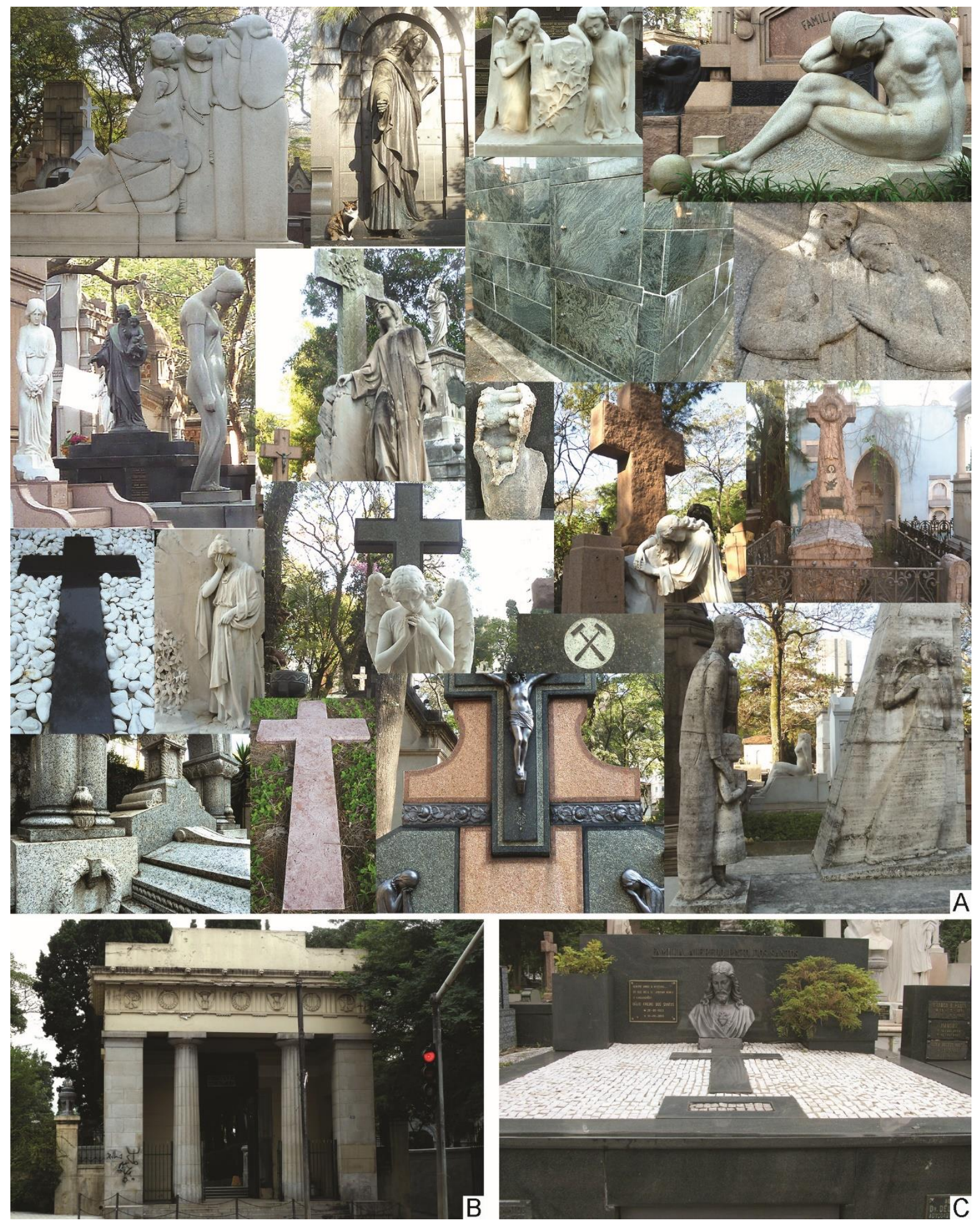

Figura 8.13. Cemitério da Consolação, São Paulo. A. Mosaico com diferentes litotipos que constituem os jazigos. B. Portal de entrada. C. Túmulo de Délio Freire dos Santos, um dos primeiros a realizar visitas guiadas no cemitério. 

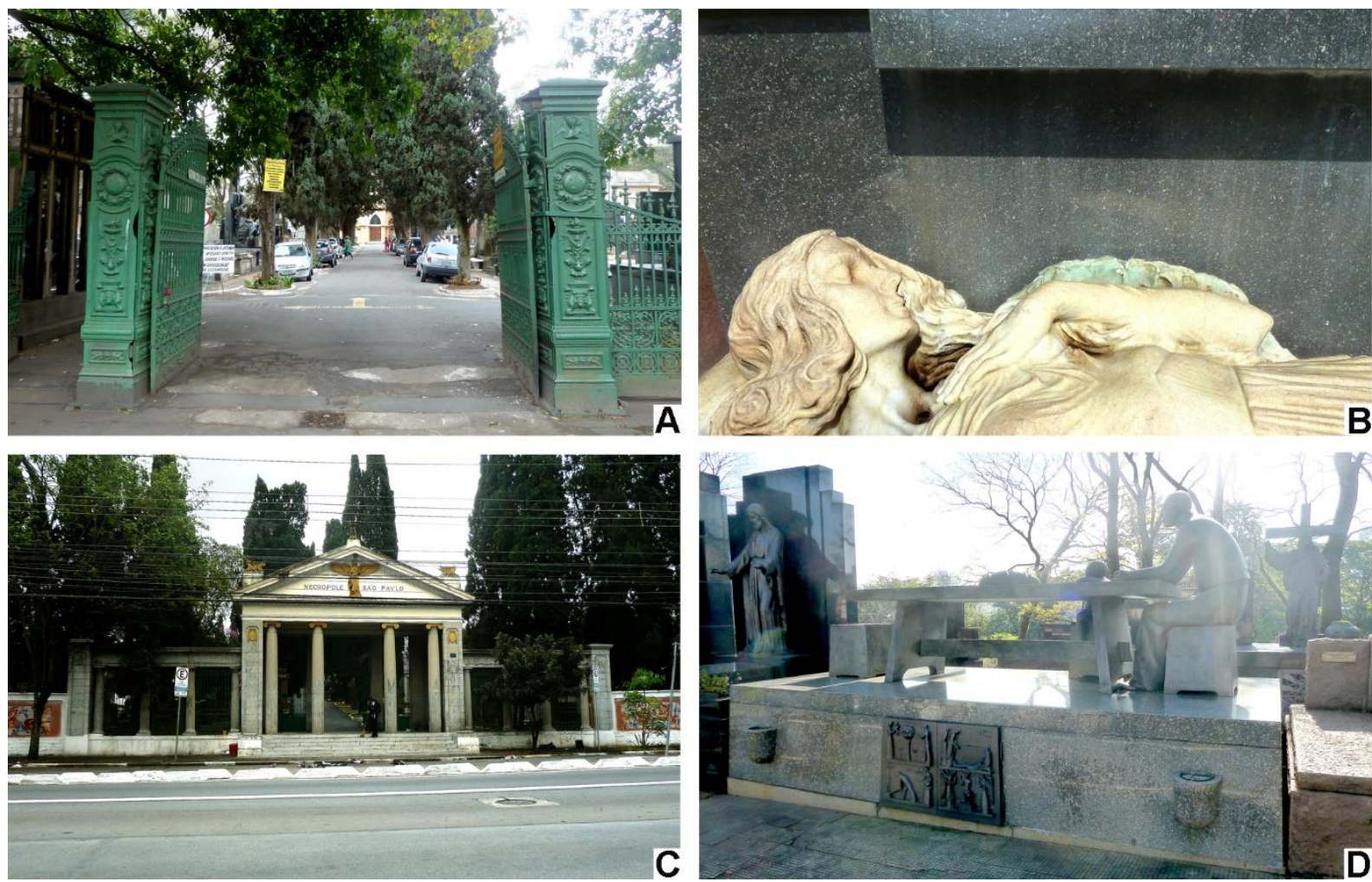

Figura 8.14. A e B. Cemitério do Araçá, São Paulo. B. Jazigo em mármore e Granito Preto Bragança. C e D. Cemitério São Paulo, São Paulo. D. Jazigo em bronze e Granito Cinza Mauá.

Pela sua importância para a história do Brasil e pelo grande mineralogista que foi, merece destaque José Bonifácio de Andrada e Silva, o Patriarca da Independência, que está sepultado no Pantheon dos Andradas, na cidade de Santos, juntamente com seus irmãos Antônio Carlos Ribeiro de Andrada Machado e Silva, Martim Francisco Ribeiro de Andrada e Patrício Manoel de Andrada e Silva. Construído em 1921, o panteão é revestido com serpentinito italiano, calcário fossilífero e mármores de cores diversas (preto com venulações brancas e douradas, branco amarelado e cinza), com escultura de mármore branco de autoria de Rodolpho Bernadelli (Figura 8.15A).

O leitor não deve estranhar se, ao visitar o Cemitério da Consolação, deparar com o túmulo de José Bonifácio de Andrada e Silva (Figura 8.15B). Na realidade, trata-se do túmulo do senador José Bonifácio, o Moço, sobrinho do mineralogista, que é homônimo do tio mineralogista e posteriormente político (Garcia 2010).

O primeiro cemitério protestante do Brasil foi construído em 1811 na Fazenda Ipanema (Iperó, $\mathrm{SP})$, berço da siderurgia do país. Suecos e alemães foram contratados para trabalhar na recém aberta Real Fábrica de Ferro. Com a ocorrência do primeiro óbito desses estrangeiros, os padres católicos não autorizaram o sepultamento de um protestante em um cemitério católico. Assim, foi autorizado por D. João VI a construção de um cemitério protestante para o sepultamento desses trabalhadores estrangeiros. O cemitério está preservado e pode ser visitado, juntamente com os remanescentes da primeira usina siderúrgica no país, hoje área pertencente à unidade de conservação Floresta Nacional (Flona) de Ipanema. Os jazigos são constituídos pela pedra local, o Arenito Itararé, e mármore branco, além das cruzes de ferro fundido na própria siderúrgica (Figura 8.16). 

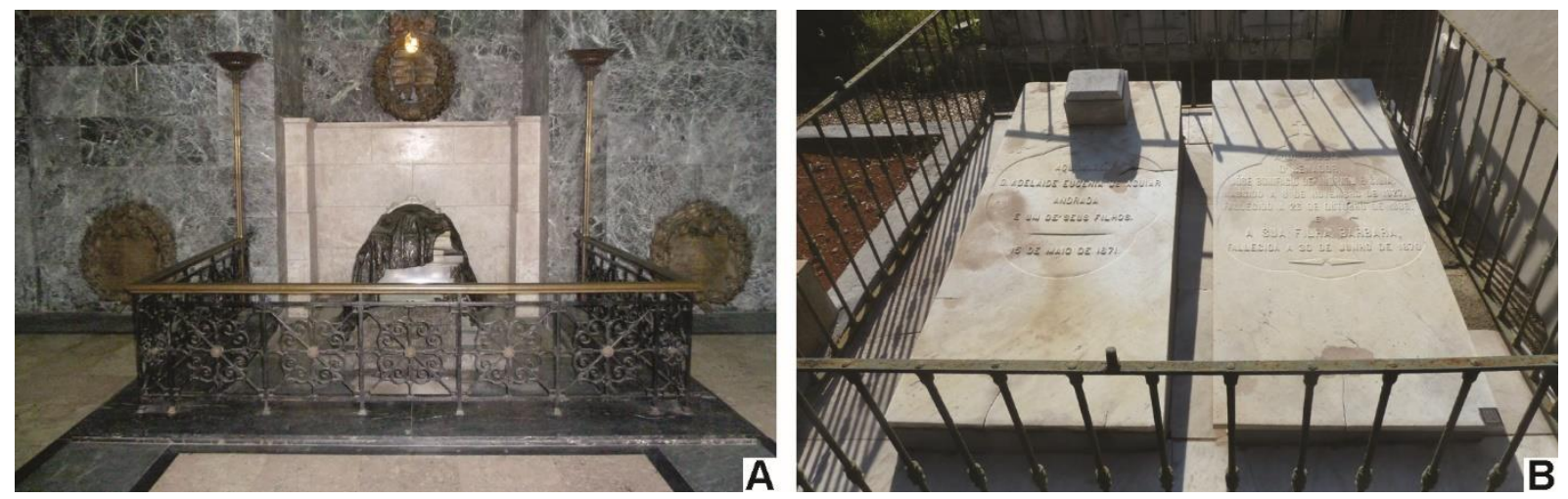

Figura 8.15. A. Túmulo de José Bonifácio, Pantheon dos Andradas, Santos. B. Túmulo do sobrinho de José Bonifácio, Cemitério da Consolação, São Paulo.
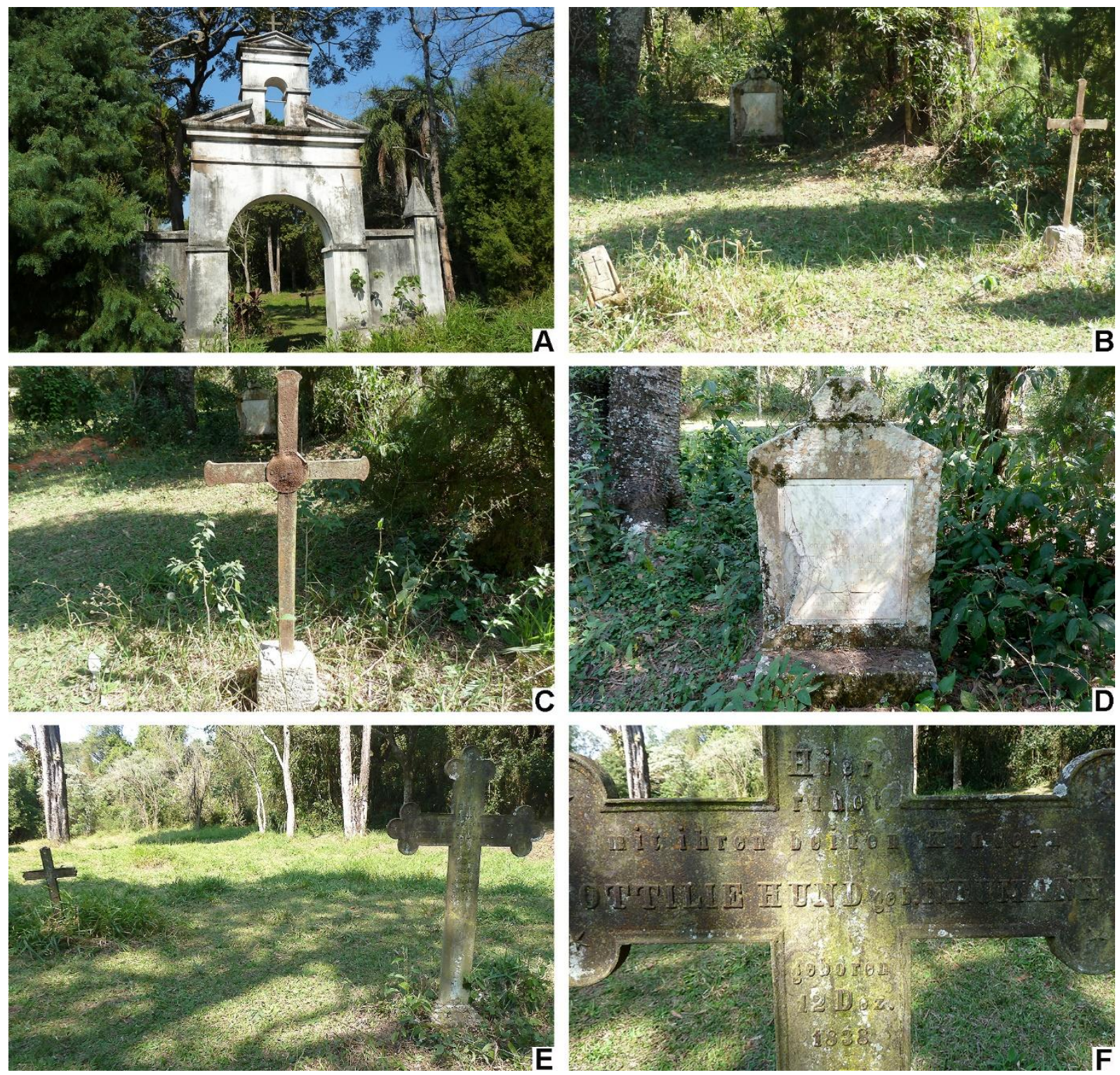

Figura 8.16. Cemitério Protestante na Flona de Ipanema, Iperó (SP). A. Portal de entrada em alvenaria. B. Interior do cemitério. C. Túmulo com cruz de ferro e pedestal de arenito. D. Túmulo de arenito com placa de mármore. E. Túmulos com cruz de ferro e pedestal de arenito. F. Detalhe de E, inscrições em alemão. 
No Cemitério da Saudade, inaugurado em 1892, na cidade de Ribeirão Preto (SP), Borges (2002) classifica os túmulos em jazigo-capela, túmulo monumental, túmulo porte-médio e túmulo simples. Foi o quarto cemitério da cidade e nada resta dos antecessores. Segundo a autora, as estátuas eram provenientes de marmorarias locais ou vinham já prontas das grandes marmorarias de São Paulo. A primeira marmoraria da cidade acompanha o ano de inauguração deste cemitério, implantada pelo escultor italiano Carlos Barberi, originário da cidade de Amparo. A marmoraria, demolida na década de 1940, situava-se no espaço hoje ocupado pela Biblioteca Altino Arantes.

Os cemitérios aqui abordados apontam que inicialmente utilizava-se Mármore Carrara na construção dos túmulos, financiados pelos barões do café. Posteriormente, foi utilizado o mármore cinza e por volta de 1920 começou-se a utilizar o granito. Esta sequência explica-se pela decadência do ciclo do café e consequentemente a utilização de materiais nacionais mais baratos.

\subsection{Geologia eclesiástica}

Assim como os cemitérios, as igrejas (principalmente as mais antigas) também apresentam uma grande diversidade pétrea em sua constituição.

Geologia eclesiástica é uma terminologia nova no Brasil, mas que já é utilizada na Europa desde os anos 2000 (Sutherland 2000, Caetano et al. 2003, Potter 2005). Em um dos trabalhos mais recentes, foi proposto um roteiro de geoturismo eclesiástico nas igrejas localizadas no triângulo histórico da cidade de São Paulo, delimitado pelo Largo São Bento, Largo São Francisco e Igreja da Ordem Terceira do Carmo (Machado \& Del Lama 2015).

Neste trabalho, além de descrever os litotipos existentes nas igrejas São Francisco, Ordem Terceira do Carmo, São José de Anchieta, Catedral Metropolitana e Basílica Nossa Senhora da Assunção, também são abordadas as igrejas europeias Pantheon (Roma), Basílica São Pedro (Vaticano), Abadia de Westminster (Londres), Templo da Sagrada Família (Barcelona), Batistério de Parma e Catedral de Florença, contrastando pedras antigas e pedras mais modernas ainda em exploração.

Em uma das fases da construção do Templo da Sagrada Família (a igreja continua até hoje inacabada), houve uma exposição dentro da igreja, intitulada Pedres del Temple, Roques dels Temps, onde foram instaladas séries de painéis cada qual contendo cada pedra que estava sendo usada na construção da igreja (Figura 8.17). Cada painel localizava onde estava sendo utilizada determinada pedra e a respectiva descrição, apresentando a mineralogia acompanhada de fotomicrografia da lâmina petrográfica, textura, estrutura e propriedades físicas, além de uma amostra da pedra em questão. Trata-se de uma verdadeira aula de petrografia no meio de um canteiro de obras. Gaudí se inspirava nas formas da natureza para fazer seus projetos, tanto do reino vegetal, como do reino mineral, como a pirita, estilo este que é retratado nas formas do Templo da Sagrada Família.

Sem sombra de dúvida, se existe o melhor lugar para se fazer geoturismo eclesiástico, este local é em Roma. Com suas inúmeras igrejas, elas são repletas de exemplos de marmi antichi (Figuras 2.5H, 2.8A, 2.8B, 2.9A, 2.9C, 2.24C, 2.24D), tais como, Granito Rosso di Aswan, Granito del Foro, Africano (brecha tectônica), Pórfiro Rosso Antico (dacito-andesito, também 
conhecido como Pórfiro Imperial), Pórfiro Verde Antico (metandesito), Verde Antico (brecha oficálcica), Cottanello Antico (brecha tectônica), Giallo Antico (calcário), Portasanta (calcário), Cipolino (mármore), Pentelico (mármore), Mármore de Carrara, Mármore da Aquitânia (brecha tectônica) e Pavonazzetto (mármore brechado).

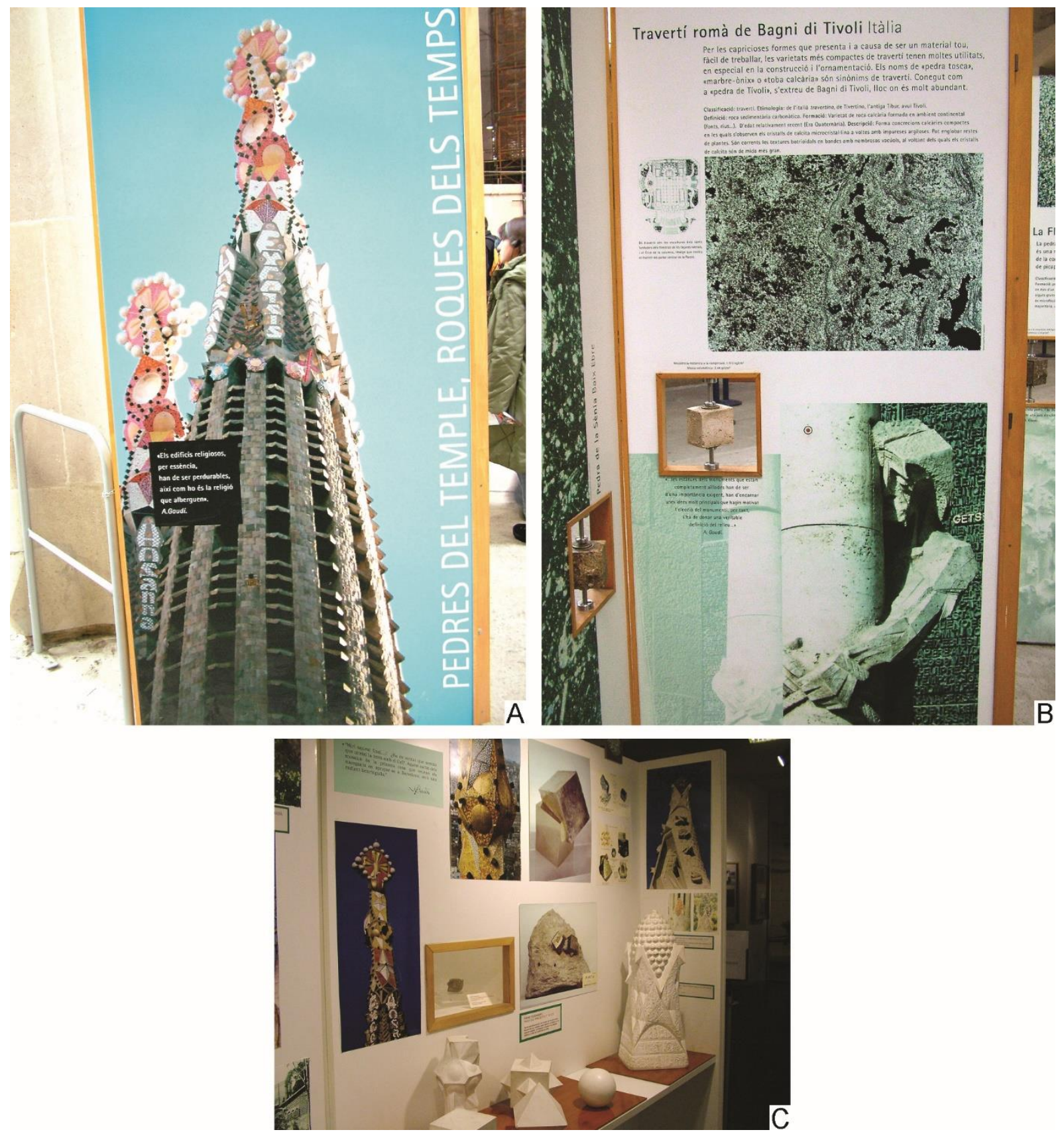

Figura 8.17. Templo da Sagrada Família, Barcelona, Espanha. A e B. Paineis da exposição Pedres del Temple, Roques dels Temps, 2007. C. Exposição em museu da igreja. Fotografias: Lauro K. Dehira.

Os marmi antichi eram pedras importadas, extraídos durante a Roma Imperial e provenientes das colônias do Egito, da Ásia Menor, da Grécia, da França, da Argélia, da Tunísia e também da própria Itália. O termo englobava não só o autêntico mármore, mas uma ampla gama de 
litotipos de diversas composições. Uma descrição dos mármores antigos pode ser encontrada em Borghini (1989) e Price (2007).

A seguir são citados outros exemplos relacionados à Geologia Eclesiástica.

A Igreja de São Roque (Figura 8.18), em Lisboa, foi construída no final do século XVI. É um dos raros edifícios que não foi afetado pelo catastrófico terremoto de 1755. Com uma fachada exterior simples, revestida de Lioz, é em uma de suas nove capelas que o interesse geológico se volta. A Capela de São João Batista, construída entre 1742 e 1747 em Roma e instalada nesta igreja, tem qualidade artística excepcional, onde podem ser observados diversas pedras e minerais, tais como: lápis-lazúli, Verde Antico, alabastro, Mármore da Aquitânia (Grand Antique), Mármore Carrara, ágata, ametista e brecha. Na Capela da Nossa Senhora da Doutrina há mármores embutidos.
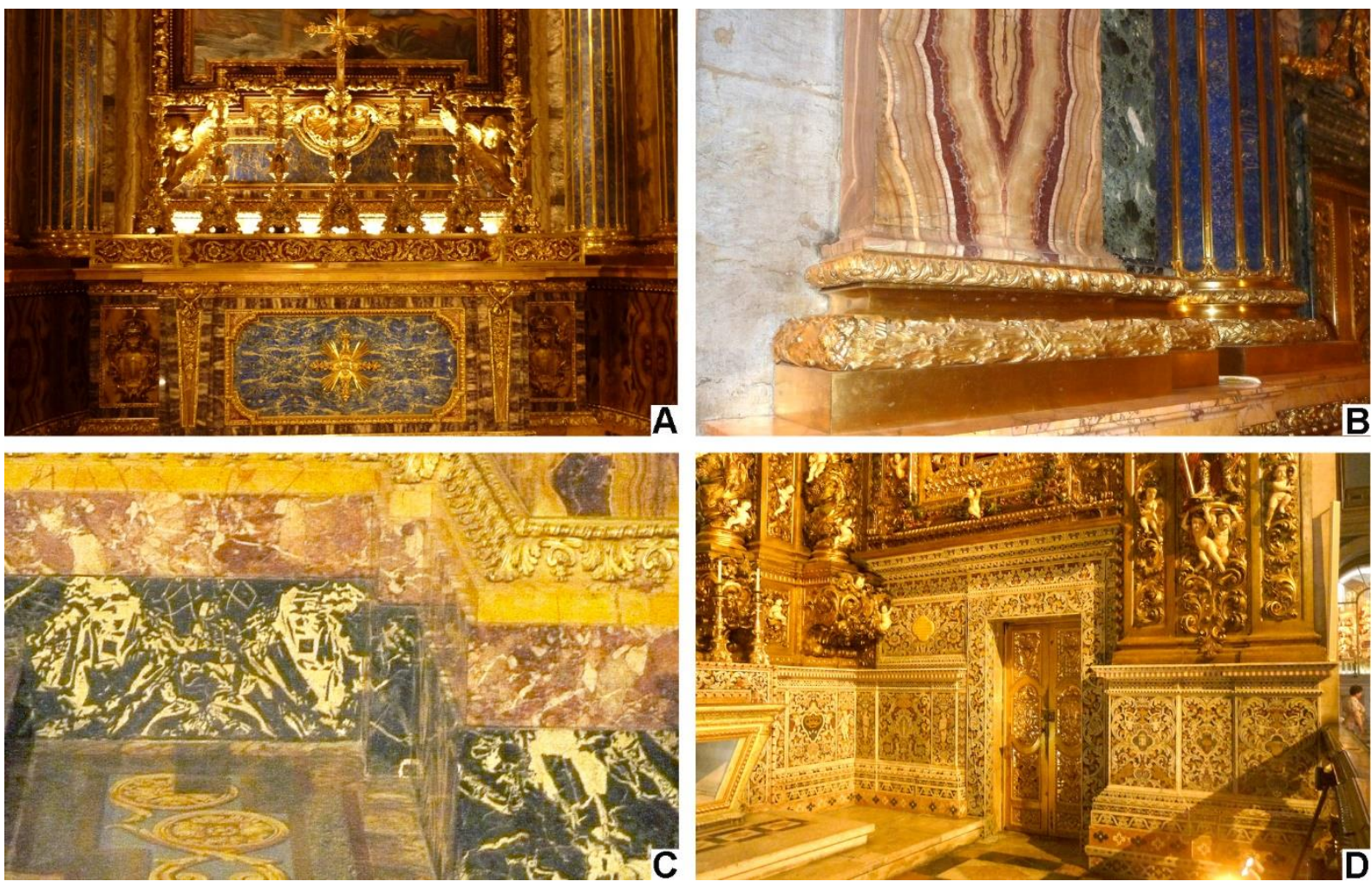

Figura 8.18. Igreja de São Roque, Lisboa, Portugal. A a C. Capela de São João Batista e os Marmi Antichi. D. Capela da Nossa Senhora da Doutrina e os mármores embutidos.

O Mosteiro São Vicente de Fora, em Lisboa, foi inaugurado em 1629. É muito rico em azulejos do período barroco, com mais de 100 mil peças, incluindo ilustrações das fábulas de La Fontaine. A sacristia é revestida de mármores policromados embutidos, incluindo o Lioz em suas várias tonalidades e a Brecha da Arrábida.

Várias outras igrejas portuguesas utilizaram o calcário em suas construções, tais como o Mosteiro de Batalha, o Mosteiro de Alcobaça (com os túmulos de D. Pedro I e Inês de Castro), a Sé Velha de Coimbra (com a Porta Especiosa), o Mosteiro dos Jerónimos (com seu claustro inteiramente esculpido), o Convento de Mafra, entre outras. 
A paisagem de Salamanca é dominada pela Velha Catedral (estilo românico) e pela Nova Catedral (estilo gótico), em um dos raros momentos da história onde se preserva o antigo e se constrói o novo ao lado (Figura 8.19). Em ambas foram utilizadas a Piedra Villamayor, que é um arenito arcoseano, também conhecida como Pedra Dourada devido ao aparecimento de uma pátina com esta cor. Trata-se de uma pátina artificial devido a tratamento químico para homogeneizar a cor da pedra (Garcia-Talegón et al. 2015). Na base da Nova Catedral foi usado o Leucogranito com Turmalina Martinamor (Piedra Pajarilla), acima o conglomerado silicificado e sobrejacente a Piedra Villamayor. Na Igreja de Santo Estevão também foram utilizadas estas mesmas pedras, além da Pedra Vaugnerita (rocha diorítica com grandes cristais entrecruzados de biotita e anfibólio).
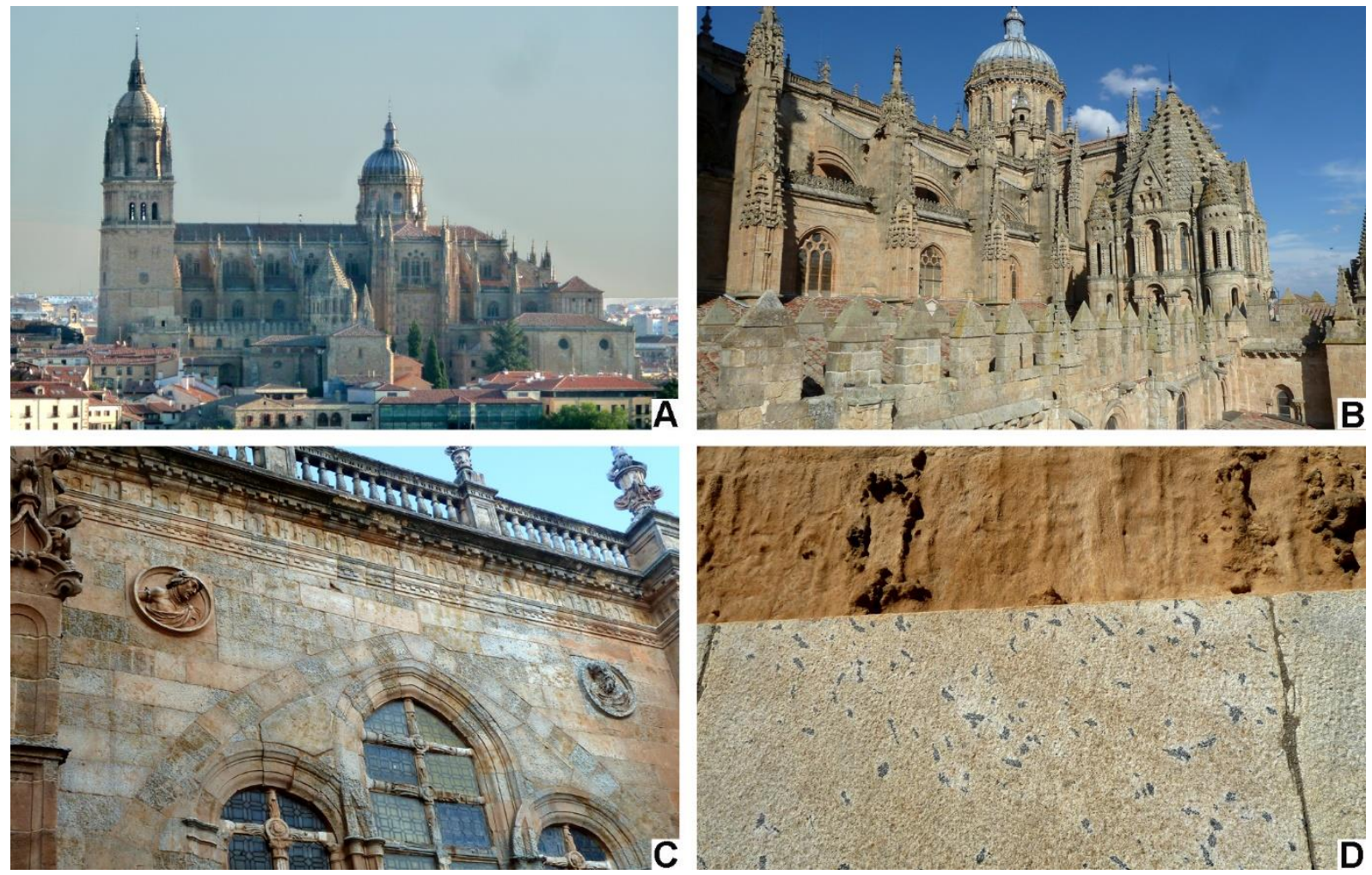

Figura 8.19. As catedrais de Salamanca, Espanha. A. A nova (na parte posterior e dominando a paisagem) e a velha catedral (na parte anterior e à esquerda). B. Detalhes das cúpulas gótica (à esquerda) e românica (à direita). C. Piedra Villamayor na nova catedral. D. Piedra Pajarilla na base da nova catedral, notar os cristais de turmalina.

A construção da Catedral de Colônia, na Alemanha, iniciou-se em 1248 e levou mais de 600 anos para ser finalizada. Boa parte dela foi construída com o traquito de Drachenfels (Figura 8.20), local-tipo onde foi descrito esta rocha. É um traquito porfirítico, com cristais de sanidina centimétricos e estrutura de fluxo. Também foram utilizados arenito e basalto. A parte mais nova está sendo substituída por calcário fossilífero. O traquito pode ser observado também em muitos edifícios em Bonn, mas não é mais explorado. 

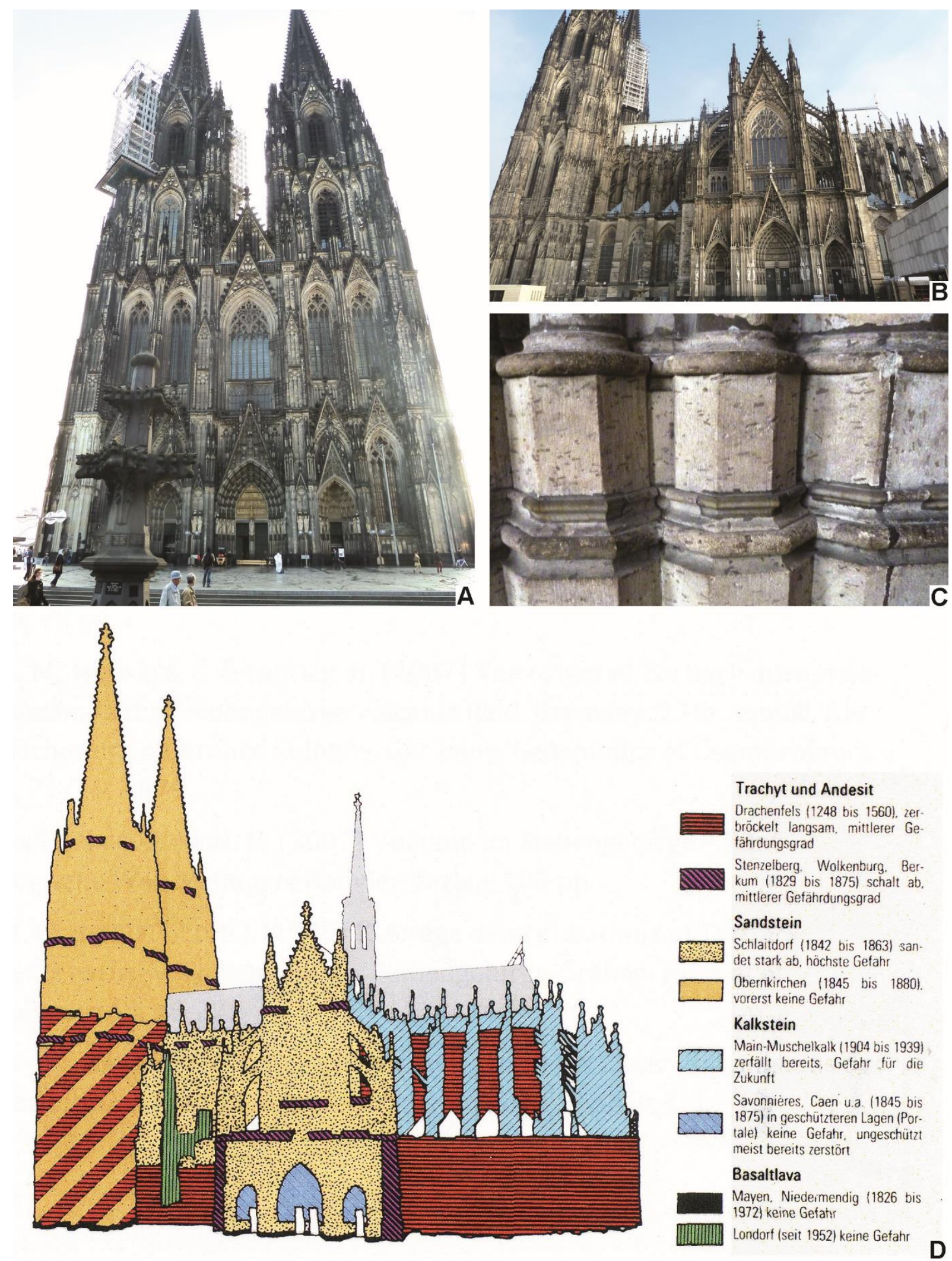

Figura 8.20. Catedral de Colônia, Alemanha. A. Fachada frontal. B. Fachada lateral. C. Traquito de Drachenfels. D. Mapeamento dos litotipos utilizados na construção da igreja. Fonte: Grabert (1998, apud Schumacher 2012). Fotografias A a C: Lauro K. Dehira. 
Considerando que afrescos são constituídos por materiais geológicos, os mosteiros pintados interna e externamente da Romênia merecem destaque. Situados na região de Bucovina, são considerados coletivamente como patrimônio da humanidade. O primeiro mosteiro foi construído quando Estevão, o Grande, teve sua primeira vitória contra os turcos no século $\mathrm{XV}$, resistindo à expansão do Império Otomano. Os outros mosteiros foram sendo construídos à medida que o príncipe moldávio ia conquistando mais vitórias. As pinturas são relacionadas com passagens do Novo e Velho Testamento, vidas de santos e lendas locais. São exemplificados a seguir dois mosteiros (Figura 8.21).

No Mosteiro Voronet, conhecido como Capela Sistina do Oriente, predomina a cor azul, feito com lápis-lazúli. Em um dos lados, os afrescos estão muito mais deteriorados que o outro lado devido às condições climáticas. Por medida de proteção dessa parede, foi construído um muro desse lado. Já no Mosteiro Sucevita predomina a cor verde. Destaque para a ilustração da escada que leva aos céus, separando os bons dos maus.
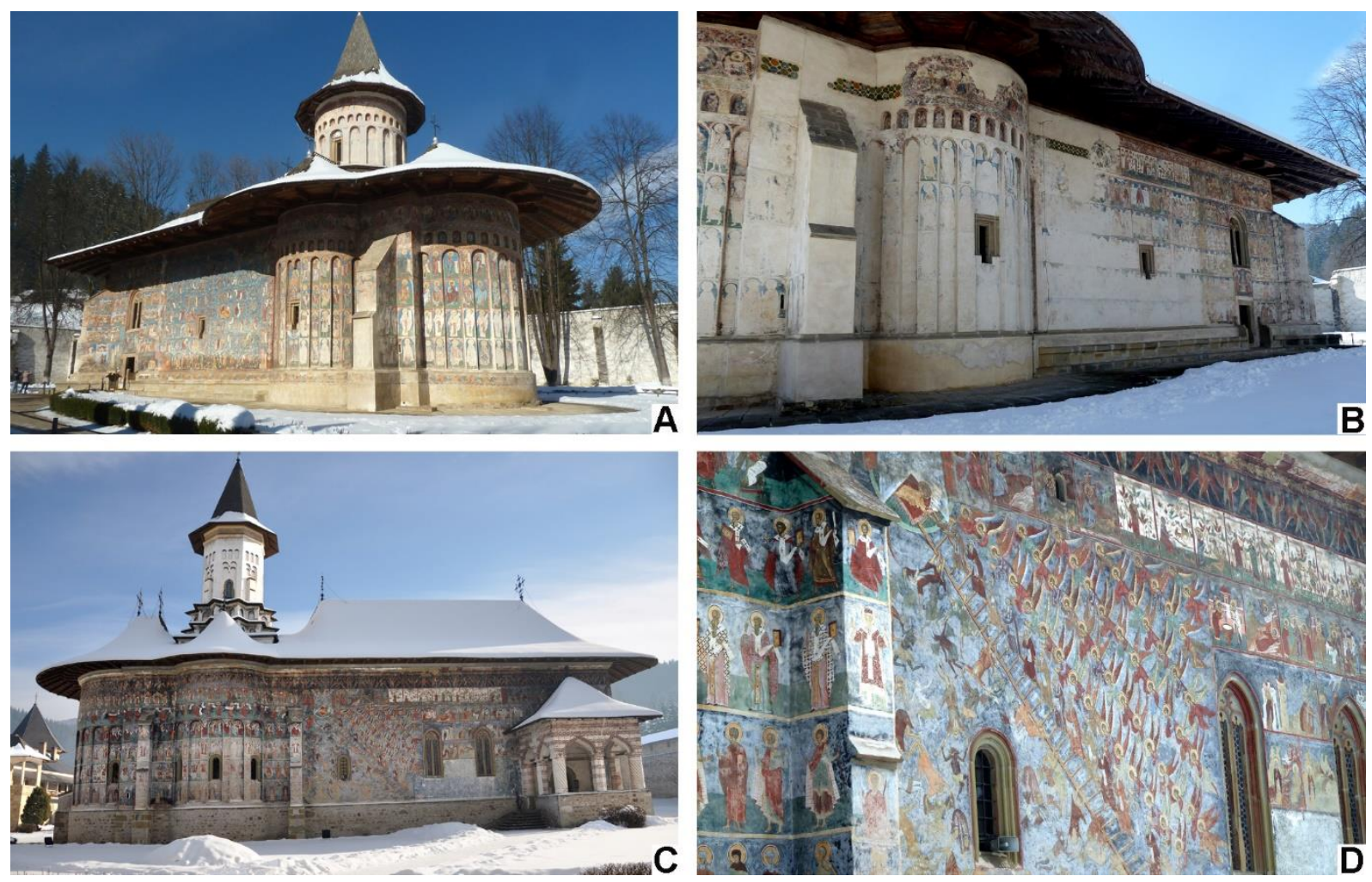

Figura 8.21. Mosteiros pintados da Romênia. A e B. Mosteiro Voronet. B. Lado intemperizado com quase ausência da pintura. C e D. Mosteiro Sucevita. D. Detalhe da escada. Fotografia C: Lauro K. Dehira.

O Brasil tem grande potencial para o desenvolvimento do geoturismo eclesiástico, pois conta com um grande número de igrejas desde a época colonial. Citam-se aqui apenas alguns exemplos.

A diversidade pétrea da Catedral Metropolitana de São Paulo, ou simplesmente Sé, foi detalhadamente abordada por Machado (2015). Há uma grande variedade de pedras nacionais e importadas, com ricos detalhes arquitetônicos. A flora e a fauna brasileira estão 
representadas nos capitéis das colunas, com destaque para o tatuzinho em granito (Figura 8.22).

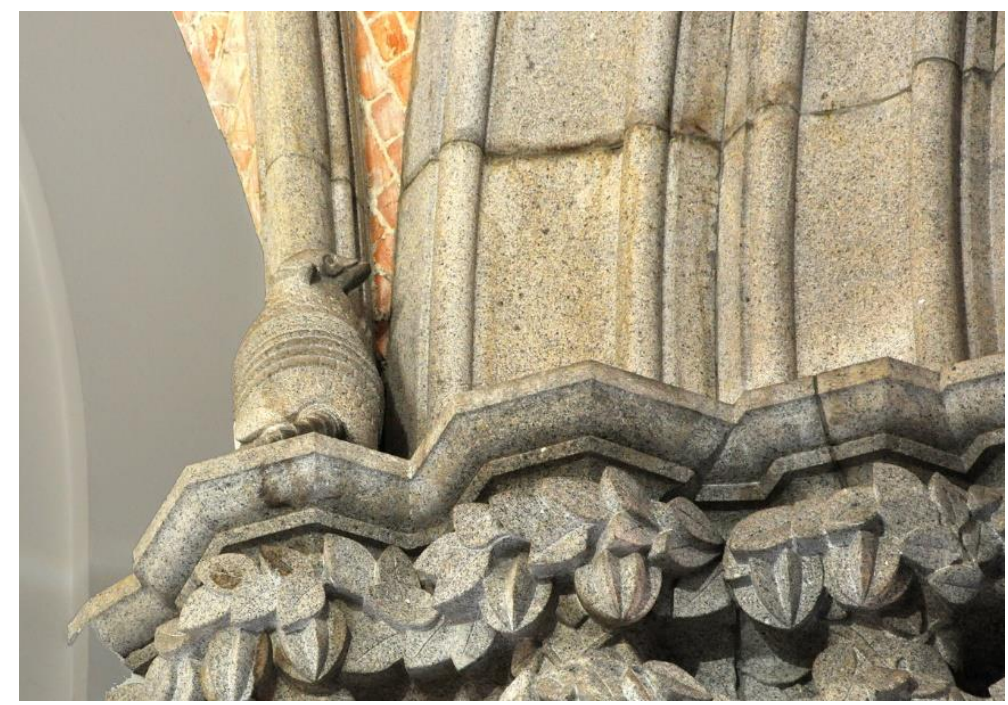

Figura 8.22. Tatuzinho em capitel da Sé, São Paulo. Fotografia: Lauro K. Dehira.

A Paróquia São Luís Gonzaga (Figura 8.23), em São Paulo, em estilo greco-romano, foi inaugurada em 1935 e teve projeto de Luís de Anhaia Mello. As colunas jônicas decimétricas do pórtico são constituídas pelo Granito Rosa Itupeva. No hall de entrada, observam-se este mesmo granito, além de um calcário preto com vênulas brancas e Granito Cinza Mauá. Os capitéis de bronze foram confeccionados pelo Liceu de Artes e Ofícios de São Paulo. O barramento e as colunas do interior são feitos com o Calcário Sete Lagoas, com cor predominante cinza/preta, diferentemente dos instalados nos edifícios do centro velho, onde sua cor é avermelhada. Foram utilizados cortes perpendiculares à estratificação e também cortes em planta, compondo um aspecto textural bastante heterogêneo. A imagem de São Luís é constituída de Mármore Carrara, de autoria de Galileo Emendabili, e no altar ainda há serpentinito da Itália e ônix do Marrocos. Os vitrais foram executados pela Casa Conrado, tradicional fabricante de vitrais sediado em São Paulo. No site da paróquia há informação dos materiais pétreos utilizados na construção da igreja, fato notável pois geralmente esses dados são omitidos e/ou não incluídos nas informações. Os nomes dos materiais pétreos apresentados são os petrográficos, não sendo apresentados os nomes comerciais, à exceção do Mármore Carrara.

A Igreja Matriz do Bom Jesus da Cana Verde, em Batatais (SP), de estilo neoclássico, foi construída entre 1928 e 1953. O piso da igreja foi trocado em 2006, havendo emissão de certidão por metro de piso doado, ou seja, cada doador recebeu um certificado de benemérito da paróquia. A escadaria é constituída pelo Granito Cinza Mauá, e no interior encontram-se os granitos Carlos Chagas, Salto e Preto Bragança, o calcário Bege Bahia, além de uma variedade de mármores (branco, branco com venulações verde, bandado com alternância de bandas brancas e verdes, bandado e dobrado com alternância de bandas brancas, rosas e verdes). Cândido Portinari pintou o altar-mor da igreja, além de um acervo de 23 telas de pintura a óleo (Figura 8.24). Outro destaque são os 48 vitrais executados por Conrado Sorgenicht Filho. 

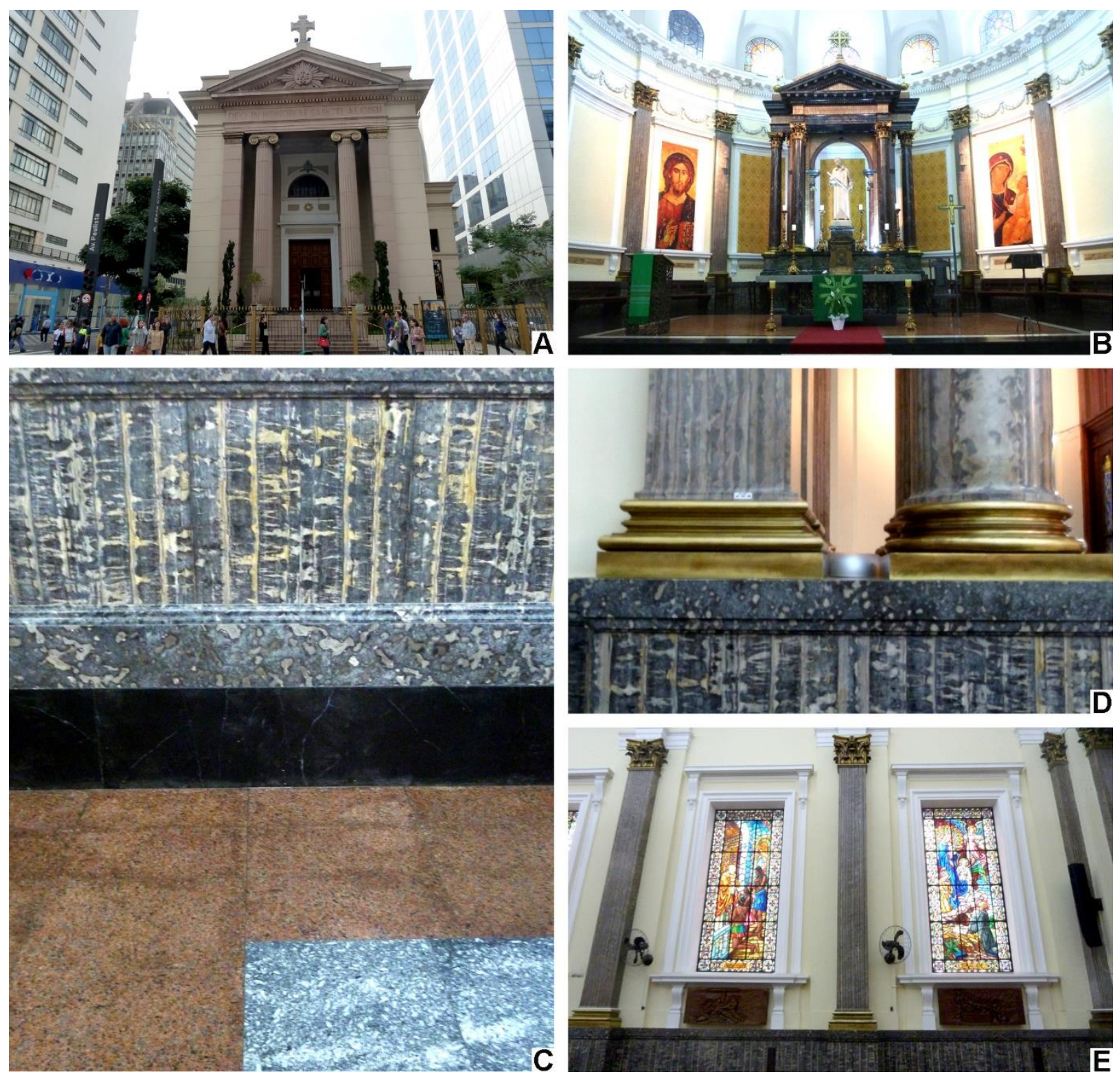

Figura 8.23. Paróquia São Luís Gonzaga, São Paulo. A. Estilo greco-romano da fachada frontal. B. Altar com estátua de São Luís em Mármore Carrara, ladeada por serpentinito e ônix. C. Piso e barramento da igreja. De cima para baixo: Calcário Sete Lagoas (corte perpendicular à estratificação e corte em planta), calcário preto, Granito Rosa Itupeva e Granito Cinza Mauá. D. Detalhe do Calcário Sete Lagoas. E. Vitrais executados pela Casa Conrado.

A Igreja da Candelária (Figura 8.25), no Rio de Janeiro, é revestida externamente pelo Gnaisse Facoidal. Internamente podem ser observados serpentinito, mármores diversos e piso policrômico.

O Santuário Nossa Senhora da Penha (Figura 8.26) em Vila Velha (ES) fica no alto do morro de rochas granitoides, tendo uma visão privilegiada de Vitória, sendo um cartão-postal capixaba. Algumas pedras decorativas são portuguesas, tais como a Brecha da Arrábida e o Lioz, e mais uma dezena de outros tipos de pedras foi utilizada na construção do santuário. 

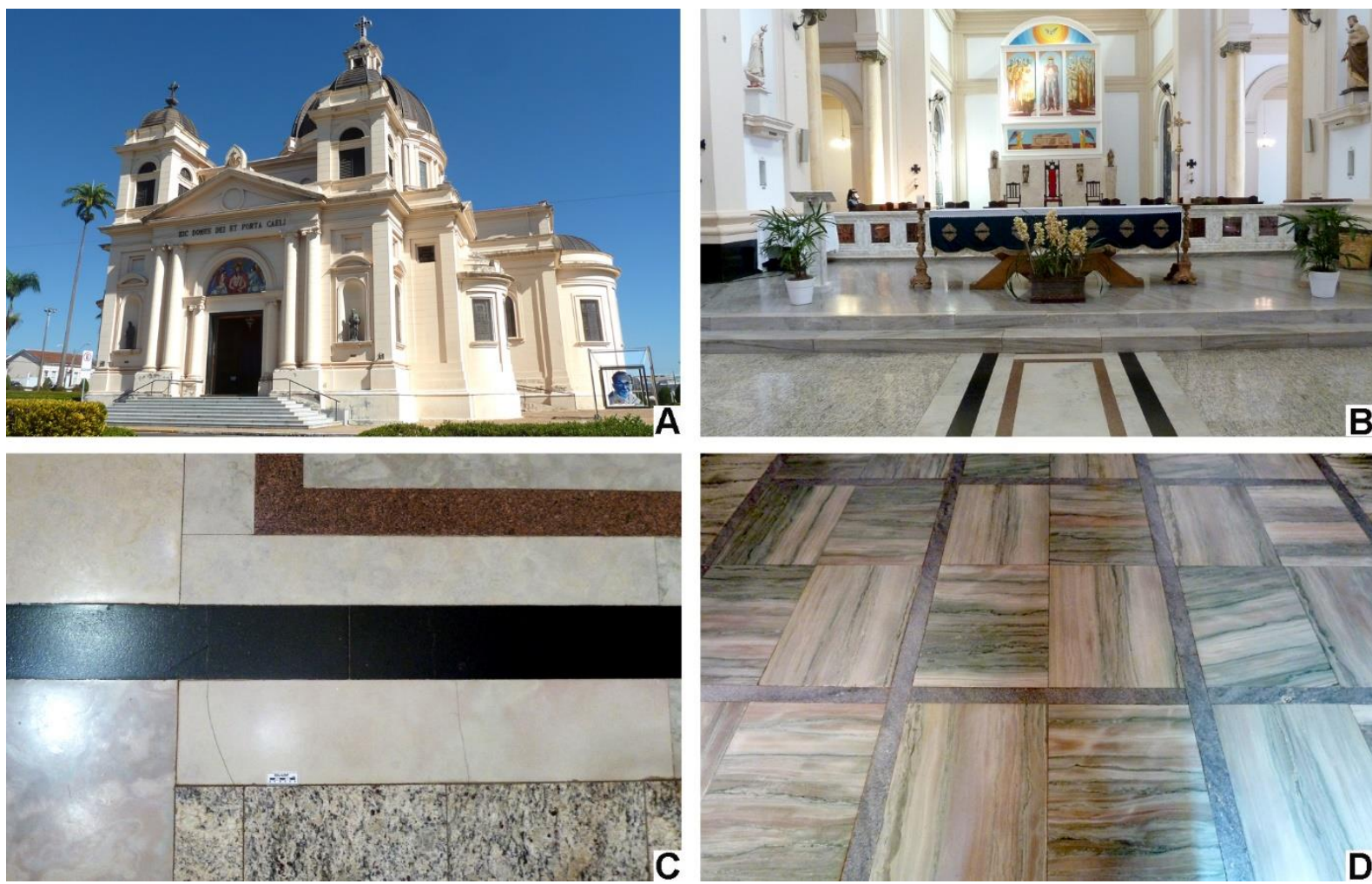

Figura 8.24. Igreja Matriz do Bom Jesus da Cana Verde, Batatais. A. Fachada externa, com destaque para o painel de Cândido Portinari à direita. B. Altar da igreja, com pintura de Portinari. C. Diversidade pétrea no piso da igreja. D. Mármore bandado e dobrado em uma das capelas.
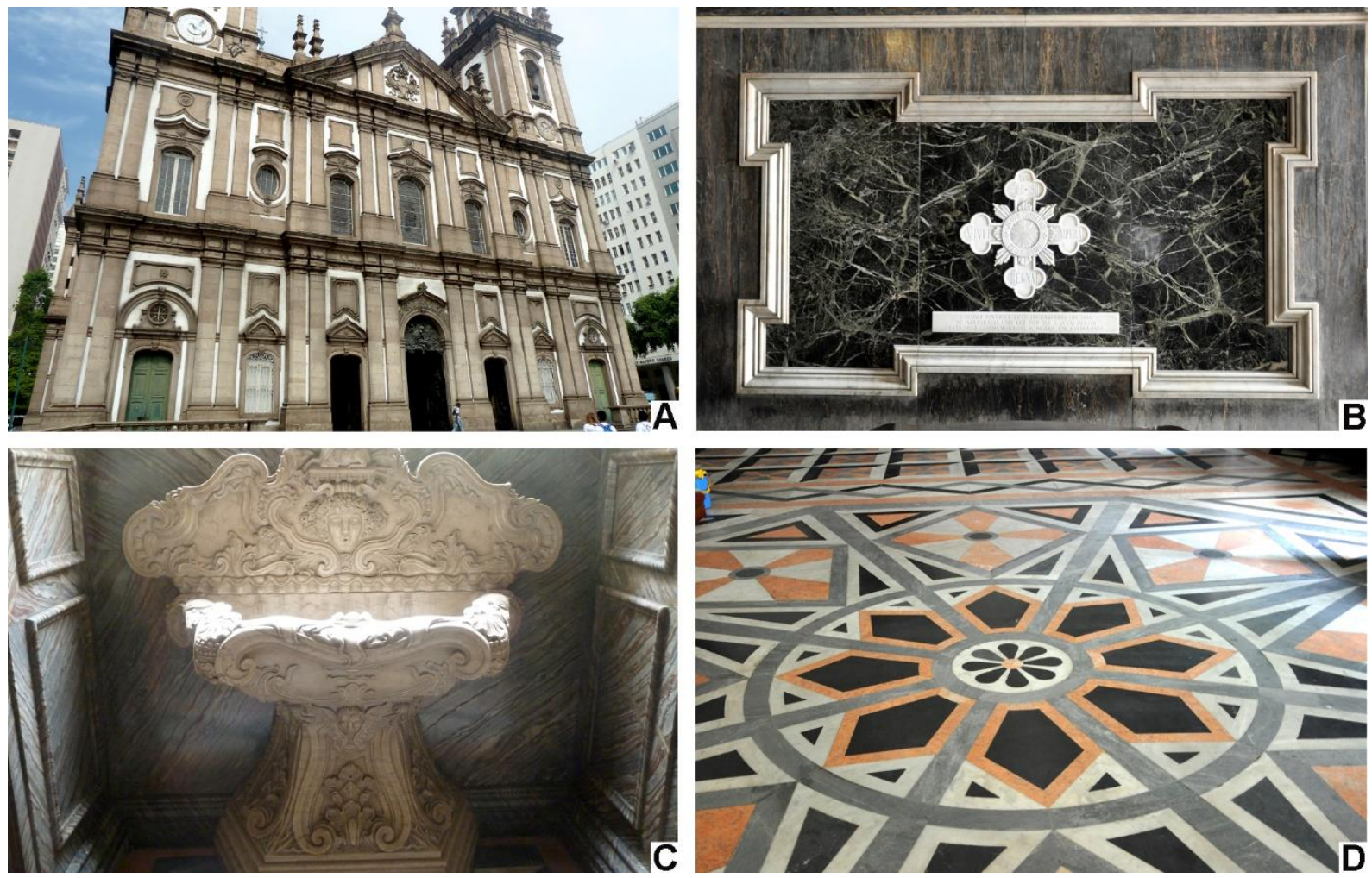

Figura 8.25. A a D. Igreja da Candelária, Rio de Janeiro. Fotografias B e D: Lauro K. Dehira. 

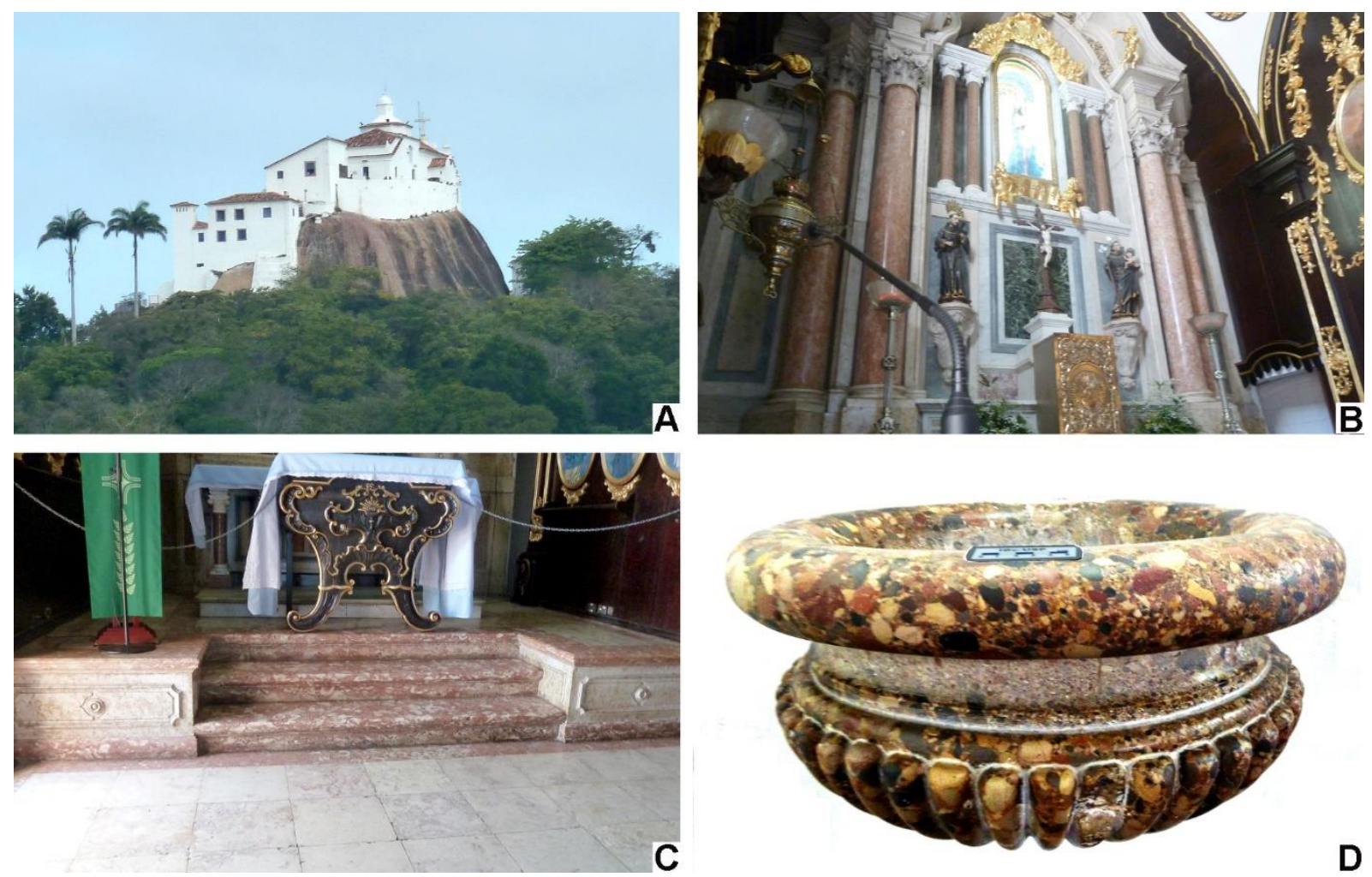

Figura 8.26. A a D. Santuário Nossa Senhora da Penha, Vila Velha, Espírito Santo.

O circuito barroco de Minas Gerais tem a presença marcante de esteatito (popularmente conhecido como pedra-sabão), uma pedra eminentemente mineira. O melhor lugar para visualizar esta pedra é na Basílica de Bom Jesus de Matosinhos, construída entre 1757 e 1875, com os doze profetas de Aleijadinho, em Congonhas (MG) (Figura 8.27). Esta pedra, juntamente com o quartzito, está presente nas igrejas de Ouro Preto, como por exemplo na Igreja São Francisco de Assis. O quartzito também foi utilizado no Mosteiro do Caraça.

Fugindo completamente do estilo barroco, em Miguel Bournier, distrito de Ouro Preto, há uma igreja dentro do domínio da fábrica da Gerdau e por ela mantida, que apresenta pedras ornamentais diversas e coloridas, tais como, calcários, fossíliferos ou não, mármores, serpentinito e jaspe (Figura 8.28).

Muitas igrejas de Salvador foram construídas com pedras portuguesas, com destaque para o Lioz de várias tonalidades (branco, rosa claro, encarnadão, Amarelo de Negrais), os calcários Preto de Mem Martins e Azul de Sintra e a Brecha da Arrábida (Figura 8.29). Silva (2008) descreve essas pedras utilizadas nas igrejas soteropolitanas. Diferente de seus pares a fachada da Igreja da Ordem Terceira de São Francisco é toda esculpida em arenito local, sendo considerada como uma maravilha do barroco brasileiro. 

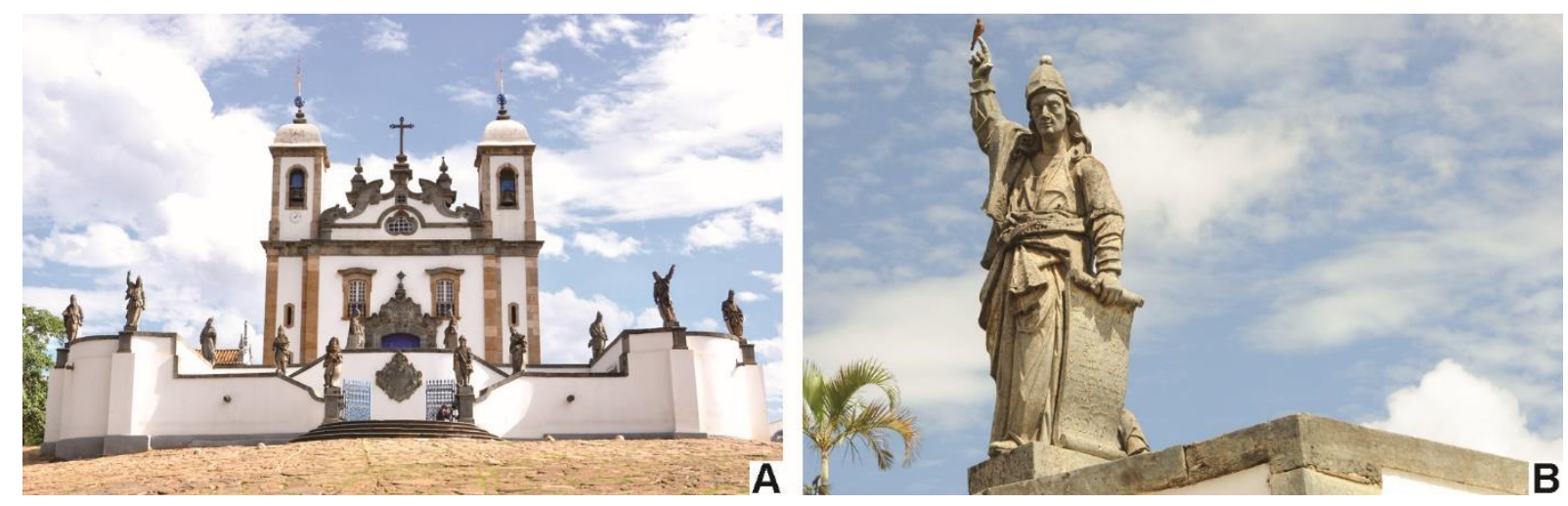

Figura 8.27. A e B: Basílica de Bom Jesus de Matosinhos, Congonhas, Minas Gerais. Fotografias: Lauro K. Dehira.
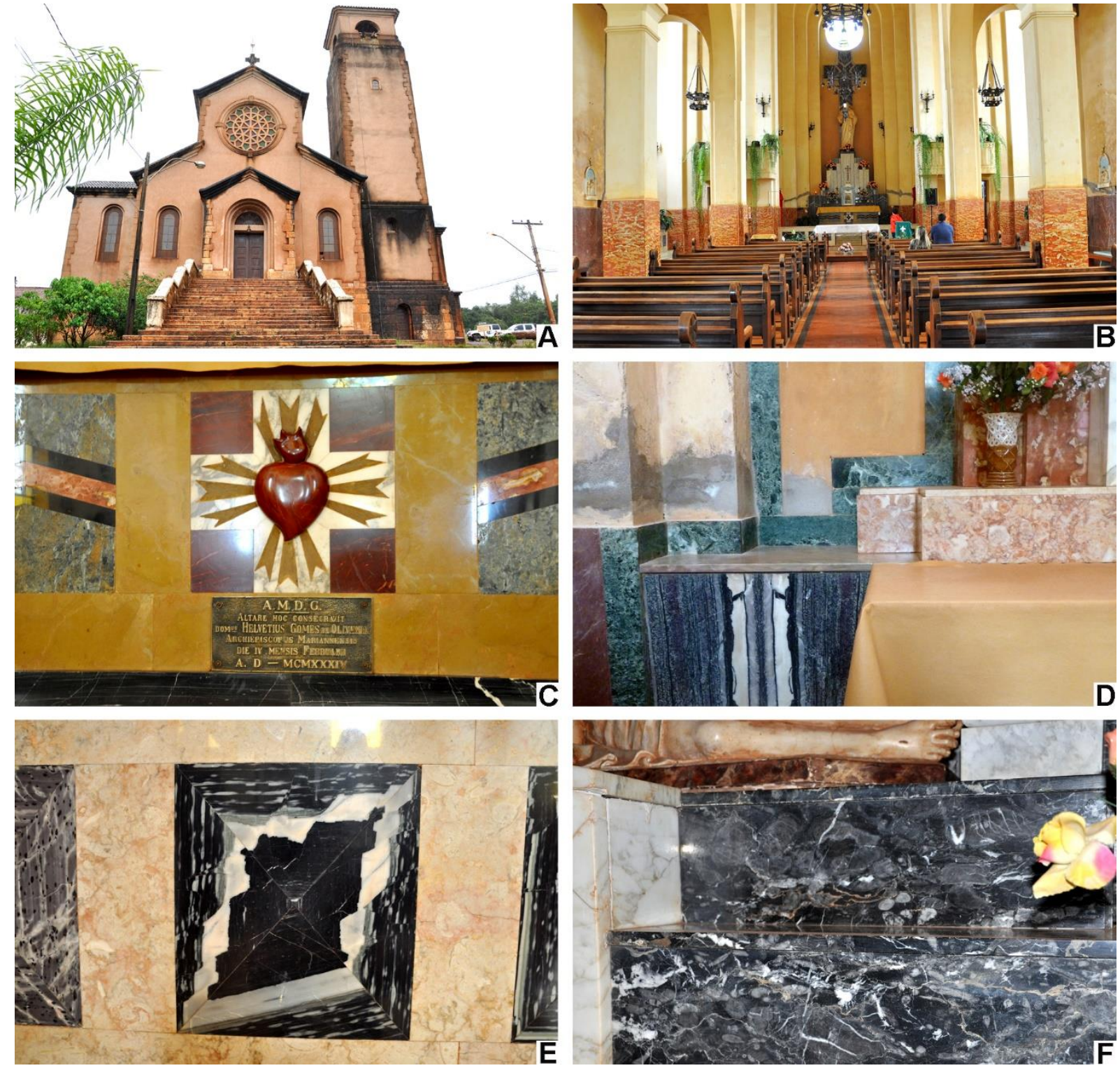

Figura 8.28. A a F. Igreja em Miguel Bournier apresentando grande diversidade de pedras ornamentais. Fotografias: Lauro K. Dehira. 

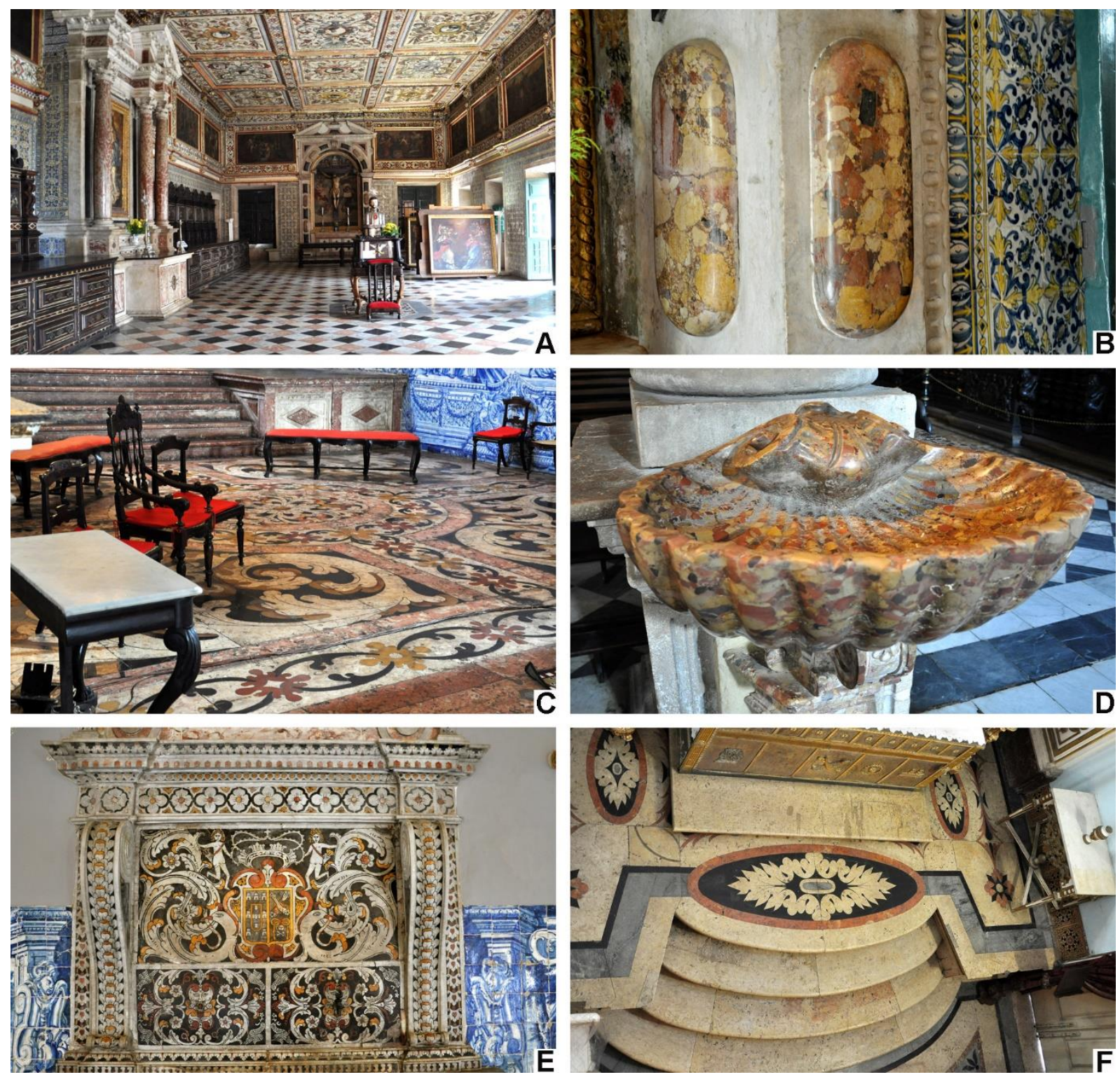

Figura 8.29. Pedras portuguesas nas igrejas soteropolitanas. A e B. Catedral Basílica. C e D. Igreja de São Francisco. E e F. Igreja da Ordem Terceira de São Francisco. Fotografias: Lauro K. Dehira.

Em Olinda e Recife quase todas as igrejas têm elementos estruturais e detalhes arquitetônicos constituídos por beachrock (Figura 8.30). Exemplos em Olinda são encontrados na Sé e na Igreja Nossa Senhora do Carmo. Exemplos em Recife, citam-se as igrejas São Pedro dos Clérigos, Nossa Senhora do Rosário dos Pretos, Divino Espirito Santo, Nossa Senhora do Livramento dos Homens Pardos, São José do Ribamar, Nossa Senhora do Carmo, Matriz de Santo Antônio e Matriz do Bairro de São José. Esta última tem escadaria em Lioz. A Basílica Nossa Senhora do Carmo apresenta internamente os beachrocks pintados e uma pia de água benta em Lioz.

A Basílica de Nossa Senhora de Nazaré, em Belém (PA), de estilo neoclássico, foi construída entre 1909 a 1923, inspirada na Igreja São Paulo Extramuros em Roma. Sua história se mistura com a festa do Círio de Nazaré. É constituída por grande variedade pétrea, tais como, 
Rosso Verona, Lioz, granito, serpentinito e outros mármores. Na fachada frontal, há detalhes e paredes revestidas de pedras brancas, verdes e rosas, inspiradas na Catedral de Florença. O Lioz, assim como em Salvador, também é muito presente nas igrejas de Belém, sendo encontrado na Igreja do Carmo e Nossa Senhora das Mercês.
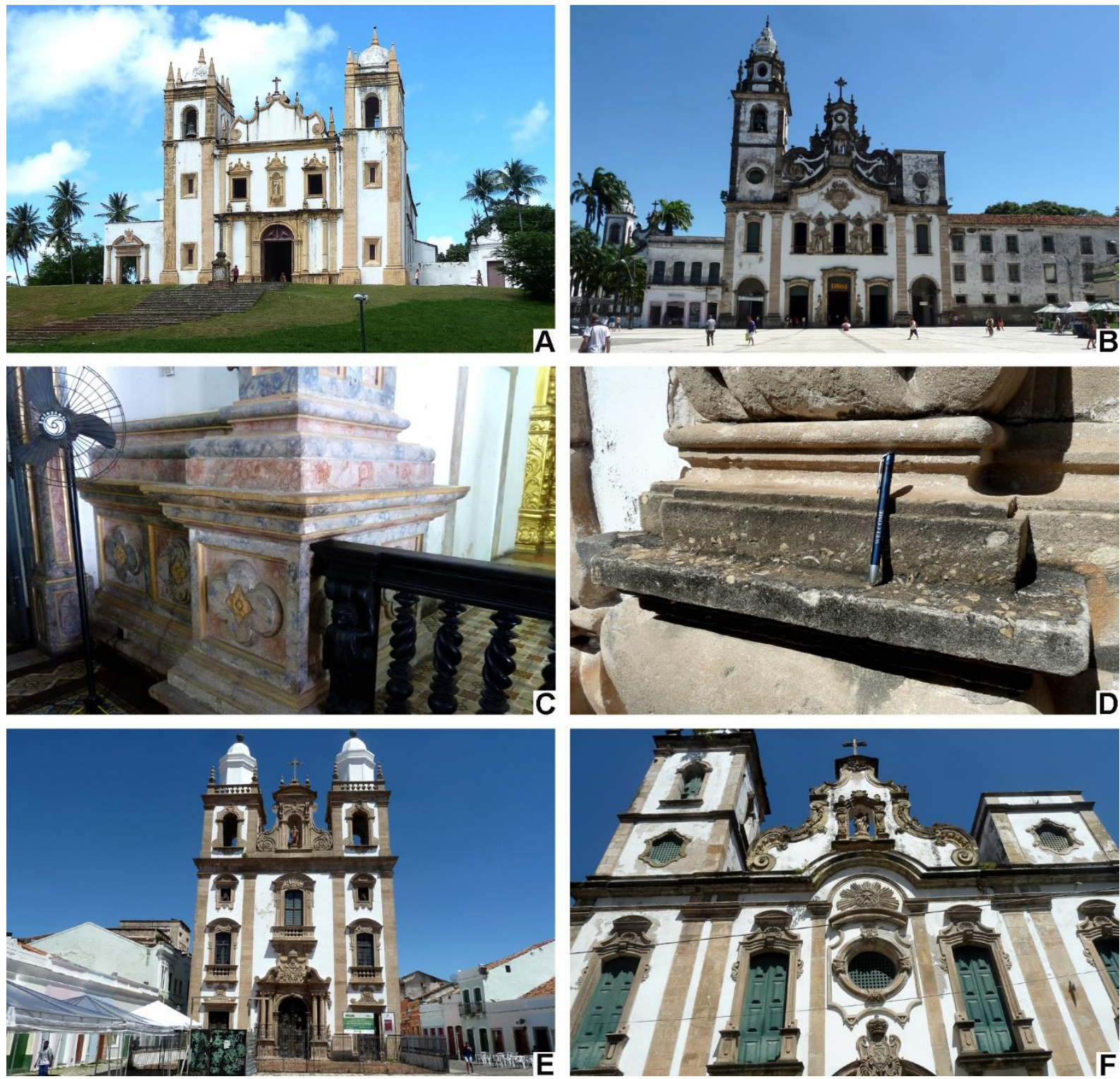

Figura 8.30. Beachrocks nas igrejas de Olinda (A) e Recife (B a F). A. Igreja Nossa Senhora do Carmo. B. Igreja Nossa Senhora do Carmo. C. Interior de B, com o beachrock pintado. D. Detalhe do beachrock da Igreja São José do Ribamar. E. Igreja São Pedro dos Clérigos. F. Igreja Nossa Senhora do Rosário dos Pretos. Fotografias: Lauro K. Dehira.

A Igreja São Gabriel, em Ametista do Sul (RS), é toda revestida internamente com drusas de ametista, e localmente com drusas de citrino e calcita (Figura 8.31). Apesar de ter sido construída em 1970, foi apenas em 2003 que foi iniciada a ornamentação da igreja com ametista, tendo sido finalizada em 2008. O exterior não foi revestido de ametista porque, provavelmente, com a exposição ao sol, a ametista (que é um mineral fotossensível) perderia sua cor, com diminuição gradual da sua tonalidade arroxeada. 

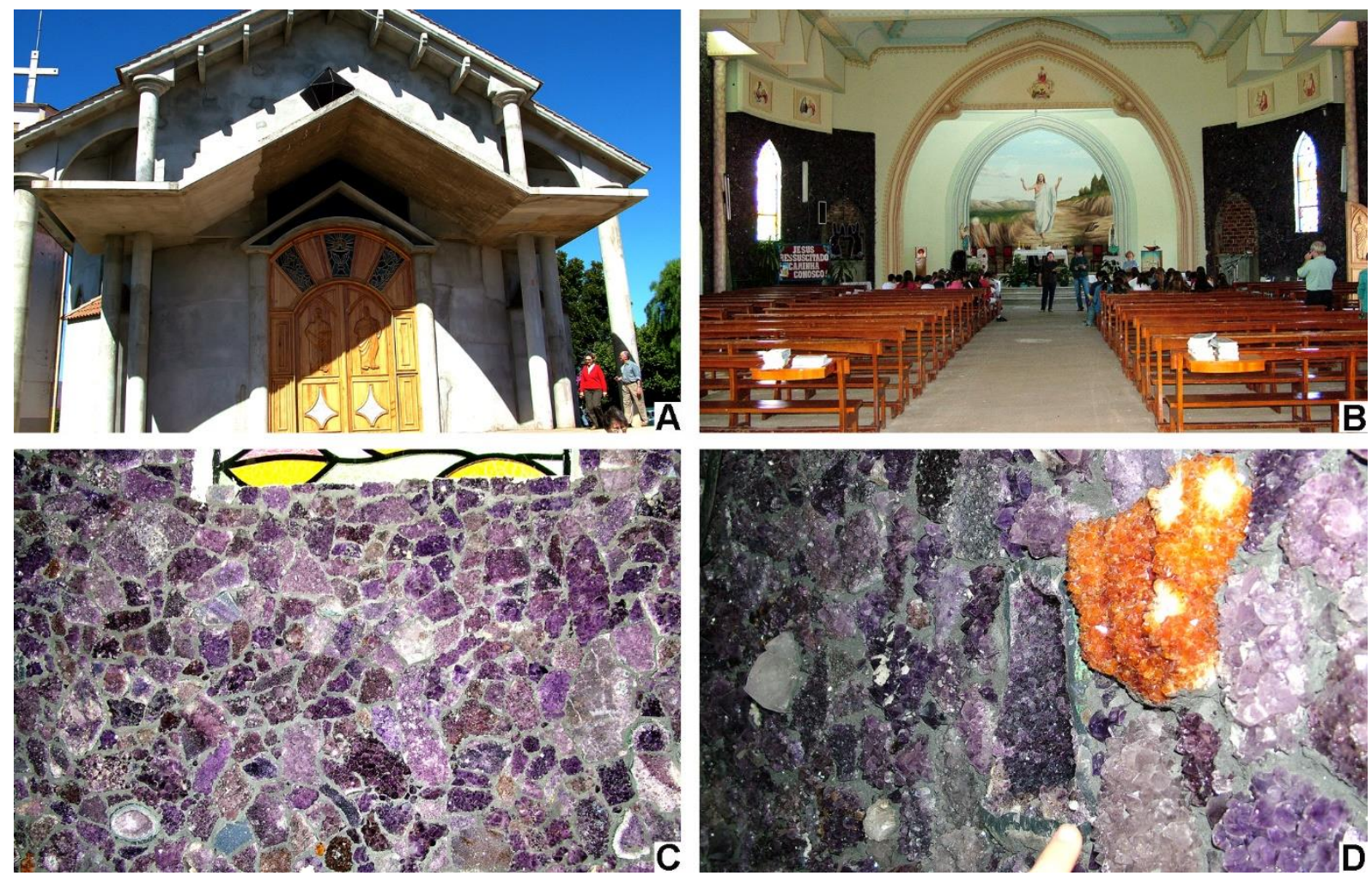

Figura 8.31. A a D. Igreja São Gabriel, Rio Grande do Sul.

Os exemplos citados aqui ratificam que igrejas do mundo todo possuem um acervo petrográfico bem diverso, e estas informações poderiam ser adicionadas nos roteiros das visitas já existentes nestas igrejas, enriquecendo o tour e contribuindo na divulgação das geociências.

\section{REFERÊNCIAS}

Anguita-Virella F. 1982. Un itinerario geológico urbano en las inmediaciones del Museo Nacional de Ciencias Naturales (Madrid). In: II Simposio sobre enseñanza de la Geología. Gijón, España, Actas, p. 165-175.

Arruda K.E.C. 2013. Geodiversidade do Litoral Norte do Estado de São Paulo, Brasil. Tese de Doutorado, Instituto de Geociências, Universidade de São Paulo (IGc-USP). (Em andamento.)

ASCE - Association of Significant Cemeteries in Europe. 2011. European Cemeteries Route. A cultural route of the Council of Europe. $60 \mathrm{p}$.

Augusto W.C.B. \& Del Lama E.A. 2011. Roteiro geoturístico no centro da cidade de São Paulo. Terrae Didatica (UNICAMP), 7(1): 29-40. Disponível em: http://www.ige.unicamp.br/terraedidatica/v7_1/pdf-v7_1/TD_7-1_3_Wilian_Batista.pdf.

Azevedo M.D.P. \& Del Lama E.A. 2015. Conservação de Coleções Geológicas. Geologia USP - Publicação Especial, 7:5-105. Disponível em: http://ppegeo.igc.usp.br/pdf/gusppe/v7/02.pdf. 
Bacci D.D.L.C. (Org.). 2015. Geociências e Educação Ambiental. Curitiba, Editora Ponto Vital,

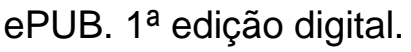

Beck-Friis J. 2010. The Protestant Cemetery in Rome. A guide for visitors. Roma, Grafica San Giovanni, $40 \mathrm{p}$.

Borges M. E. 2002. Arte funerária no Brasil (1890-1930). Ofício de marmoristas italianos em Ribeirão Preto. Belo Horizonte, C/ Arte, 312 p.

Borghini G. 1989. Marmi Antichi. Roma, De Luca Edizione d'Arte, 342 p.

Bueno B.P.S. 2015. Escritório Ramos de Azevedo - A Arquitetura e a Cidade. Exposição no Centro de Preservação Cultural da USP, 10 de abril a 17 de maio de 2015. Curadoria de Beatriz P.S. Bueno.

Caetano P.S., Verdial P.H., Gregório P., Heitor A.P., Pedro B., Silva I. 2003. A criação de circuitos geológicos no Almada Forum: um exemplo de divulgação da Geologia em meio urbano. Ciências da Terra, Lisboa, Universidade Nova de Lisboa, (n. esp. V):106-107. CDRom, p. I24-I27.

Carvalho H.L. 2010. Patrimônio geológico do centro histórico de Natal. Monografia de Trabalho de Formatura, Centro de Ciências Exatas e da Terra, Universidade Federal do Rio Grande do Norte, 105 p.

Daniels C. 2006. Graveyard Memorials. In: Henry A. (ed.) Stone Conservation. Shaftesbury, Donhead, p. 299-326.

Del Lama E.A. 2015. Educação Patrimonial e Geoconservação. In: D.D.L.C. Bacci (org.) Geociências e Educação Ambiental. Curitiba, Editora Ponto Vital, p. 356-402. 1a edição digital.

Del Lama E.A. 2017. Urban geotourism: a case study of São Paulo city, Brazil. In: Dowling R. \& Newsome D. (eds.) Handbook of Geotourism. Edward Elgar Publishing.

Del Lama E.A., Dehira L.K., Reys A.C. 2009. Visão geológica dos monumentos da cidade de São Paulo. Revista Brasileira de Geociências, 39(3):409-420. Disponível em: http://www.sbgeo.org.br/pub_sbg/rbg/vol39_down/3903/11163.pdf.

Del Lama E.A., Bacci D.D.L.C., Martins L., Garcia M.G.M., Dehira L.K. 2015. Urban geotourism and the old centre of São Paulo, Brazil. Geoheritage, 7(2):147-164. DOI 10.1007/S12371-0140119-7.

Garcia G. 2010. Mas afinal, onde está sepultado José Bonifácio? Disponível em: http://www.saopauloantiga.com.br/mas-afinal-onde-esta-sepultado-jose-bonifacio/.

Garcia M.G.M. 2015. Educação para a geoconservação: experiências e perspectivas. In: Bacci D.D.L.C. (org.) Geociências e Educação Ambiental. Curitiba, Editora Ponto Vital, p. 403444. $1^{a}$ edição digital.

Garcia-Talegón J., Iñigo A.C., Alonso-Gavilan G., Vicente-Tavera S. 2015. Villamayor Stone (Golden Stone) as a Global Heritage Stone Resource from Salamanca (NW of Spain). In: Pereira D., Marker B.R., Kramar S., Cooper B.J., Schouenborg B.E. (eds.) Global Heritage 
Stone: towards international recognition of building and ornamental stones. Londres, Geological Society, Special Publication, 407:109-120.

ICOMOS - International Council on Monuments and Sites. 2008. Illustrated glossary on stone deterioration patterns. Champigny/Marne, França, ICOMOS, 80 p. Disponível em: http://www.international.icomos.org/publications/monuments_and_sites/15/pdf/Monuments_and_ Sites_15_ISCS_Glossary_Stone.pdf.

Kanke R.A. 2013. Utilização do Granito Itaquera em obras históricas do centro da cidade de São Paulo. Monografia de Trabalho de Formatura, Instituto de Geociências, Universidade de São Paulo (IGc-USP), 159 p.

Kuzmickas L. 2013. Estado de conservação dos monumentos pétreos do Cemitério da Consolação, São Paulo. Dissertação de Mestrado, Instituto de Geociências, Universidade de São Paulo (IGc-USP), 197 p.

Kuzmickas L. \& Del Lama E.A. 2015. Roteiro Geoturístico pelo Cemitério da Consolação, São Paulo. Geociências (UNESP), 34(1):41-54. Disponível em: http://www.periodicos.rc.biblioteca.unesp.br/index.php/geociencias/article/view/9734/6544.

Liccardo A. 2010. La Pietra e l'Uomo. Cantaria e Entalhe em Curitiba. Curitiba, Beca, 156 p.

Liccardo A. \& Grassi C. 2014. Geodiversidade no Cemitério Municipal de Curitiba como elemento cultural em análises de patrimônio. Geonomos, 22:48-57.

Liccardo A., Piekarz G., Salamuni E. 2008. Geoturismo em Curitiba. Curitiba, MINEROPAR, $122 \mathrm{p}$.

Liccardo A., Mantesso-Neto V., Piekarz G. 2012. Geoturismo urbano - educação e cultura. Anuário do Instituto de Geociências, UFRJ, 35(1):133-141.

LRMH - Laboratoire de Recherche des Monuments Historiques. 2011. Petit guide à l'usage des personnes souhaitant entretenir une sépulture. 8 p. Disponível em: http://www.sppef.fr/wp-content/uploads/2014/03/sppef_guide-entretien-tombes.pdf.

Machado D.F.R. 2015. Catedral da Sé de São Paulo: análise do estado de conservação das rochas do templo por métodos não destrutivos. Dissertação de Mestrado, Instituto de Geociências, Universidade de São Paulo (IGc-USP), 180 p.

Machado D.F.R. \& Del Lama E.A. 2015. Geologia Eclesiástica no triângulo histórico paulistano: a diversidade geológica na divulgação das geociências. Terrae Didatica (UNICAMP), 11(3):138-149. Disponível em: http://www.ige.unicamp.br/terraedidatica/v11_3/PDF11-3/Td-11_3_146-2F.pdf.

Mansur K.L. 2009a. Projetos educacionais para a popularização das Geociências e para a geoconservação. Geologia USP - Publicação Especial, Revista do Instituto de Geociências USP, 5:63-74.

Mansur K.L. 2009b. Caminhos de Darwin no Estado do Rio de Janeiro. Salto para o Futuro. Disponível em: http://www.tvbrasil.org.br/fotos/salto/series/19282316-CaminhosDarwin.pdf. 
Mansur K.L., Carvalho I.S., Delphim C.F.M., Barroso E.B. 2008. O Gnaisse Facoidal: a mais carioca das rochas. Anuário do Instituto de Geociências, UFRJ, 31(2):9-22.

Mantesso-Neto V., Ribeiro R.R., Garcia M.G.M., Del Lama E.A., Theodorovicz A. 2013. Patrimônio geológico no estado de São Paulo. Boletim Paranaense de Geociências, (70):5376. Disponível em: http://ojs.c3sl.ufpr.br/ojs/index.php/geociencias/article/view/32741/21562.

Mantesso-Neto V., Andrade W.T.F., Frigerio A., Stern A.H. 2012. Guia geoturístico e histórico de Santos e São Vicente. In: 46ํㅡ Congresso Brasileiro de Geologia, Santos (SP). Santos, ABGE, Edição especial (folder).

Maxell I., Nanda R., Urquhart D. 2001. Conservation of historic graveyards - guide for practitioners 2. Edinburgh, Historic Scotland, $180 \mathrm{p}$.

Mucivuna, V.C., Del Lama, E.A., Garcia, M.G.M. 2015. Aspectos geológicos, históricos e estado de conservação das fortificações da Baixada Santista, litoral paulista. Revista do Instituto Geológico, São Paulo, 2.

Palácios F.O. 2015. Dos minerais aos materiais de arquitetura e processos de degradação: edifícios e ornamentos metálicos dos séculos XIX e XX em Belém do Pará. Tese de Doutorado, Instituto de Geociências, Universidade Federal do Pará, 110 p.

Pinto A.B.C. 2015. Geodiversidade e Patrimônio Geológico de Salvador: uma Diretriz para a Geoconservação e Educação em Geociências. Tese de Doutoramento em Geologia, Universidade Federal da Bahia, 308 p.

Piranha J.M., Del Lama E.A., Bacci D.D.L.C. 2011. Geoparks in Brazil - strategy of Geoconservation and Development. Geoheritage, 3:289-298.

Potter J.F. 2005. Ecclesiastical geology - a return to Victorian field standarts. Geoscientist, 15(10):4-7.

Price M.T. 2007. Decorative Stone. The complete sourcebook. Londres, Thames \& Hudson, $288 \mathrm{p}$.

Reys A.C., Del Lama E.A., Dehira L.K. 2008. Monumentos da cidade de São Paulo: formas de alteração e conservação. Revista CPC (Centro de Preservação Cultural da USP), (5):93$122 . \quad$ Disponível em: http://www.usp.br/cpc/v1/php/wf07_revista_interna.php?id_revista=9\&id_conteudo=22\&tipo=7.

Ribeiro J. E. 1999. Escultores italianos e sua contribuição à arte tumular paulistana. Tese de Doutorado, Faculdade de Filosofia, Letras e Ciências Humanas, Universidade de São Paulo, 6 vol.

Robinson E. 1984. London: illustrated geological walks. Edinburgh, Scottish Academic Press Ltd., Vol. I, 98 p.

Robinson E. 1985 London: illustrated geological walks. Edinburgh, Scottish Academic Press Ltd., Vol. II. 142 p. 
Rodrigues N.M. 2012. Ensaios não destrutivos em monumentos pétreos paulistanos. Monografia de Trabalho de Formatura, Instituto de Geociências, Universidade de São Paulo (IGc-USP), 75 p.

Rodrigues R.P. 2014. Comparação entre as formas de intemperismo presentes nos Cemitérios São Paulo (SP, Brasil) e Père-Lachaise (Paris, França). Monografia de Trabalho de Formatura, Instituto de Geociências, Universidade de São Paulo (IGc-USP), 54 p.

Schumacher R. 2012. Field trip to the Drachenfels, Siebengebirge. In: $7^{\text {th }}$ International Conference on Mineralogy and Museums, 27 a 29/08/12, Dresden, Alemanha, Excursão póscongresso, $8 \mathrm{p}$.

Silva P.A.B.V. 2014. Deterioração nas pedras da arquitetura mortuária do Cemitério Nossa Senhora da Soledade. Dissertação de Mestrado, Faculdade de Arquitetura e Urbanismo, Universidade Federal do Pará (UFPA), 211 p.

Silva Z.C. 2008. O Lioz português - de lastro de navio a arte na Bahia. Santa Maria da Feira, Versal Editores e Edições Afrontamento, 156 p.

Stern A.G., Riccomini C., Fambrini G.L., Chamani M.A.C. 2006. Roteiro geológico pelos edifícios e monumentos históricos do centro da cidade de São Paulo. Revista Brasileira de Geociências, 36(4):704-711.

Sutherland D.S. 2000. Ecclesiastical geology. In: Hancock P.I. \& Skinner B.J. (eds.) The Oxford Companion to the Earth. Oxford, Oxford University Press, p. 292-295.

Suzuki A.T. 2015. Estudo e análise do estado de conservação das rochas, por método não destrutivo, do Palácio da Justiça de São Paulo. Dissertação de Mestrado, Instituto de Geociências, Universidade de São Paulo (IGc-USP). (Em andamento.)

Vargas D.K. 2015. Mapeamento das rochas ornamentais no Cemitério do Araçá (SP, Brasil). Relatório de projeto Aprender com Cultura e Extensão, Instituto de Geociências, Universidade de São Paulo (IGc-USP), 12 p.

Velázquez V.F., Colonna J.V., Pletsch M.A.J.S., Silva G.A.R., Landgraf Junior O., Ferreira J. M.R., Azevedo Sobrinho J.M., Sallun A.E.M., Sallun Filho W. 2016. The current situation of protection and conservation of the Colônia impact crater, São Paulo, Brazil. GeoJournal of Tourism and Geosites, 17:7-20. 


\section{Considerações finais}

Estudar o patrimônio é fascinante. E quem intervém no patrimônio deve lembrar que o patrimônio não é propriedade privada, pertence a todos, e como tal, deve ser respeitado.

Políticas de manutenção e supervisão constante é a maneira mais eficiente de preservar os bens culturais.

O patrimônio mundial, e principalmente o brasileiro, nem sempre é bem tratado, o que pode gerar sua destruição, e consequentemente perda de identidade da civilização que o concebeu (Figura 9.1).

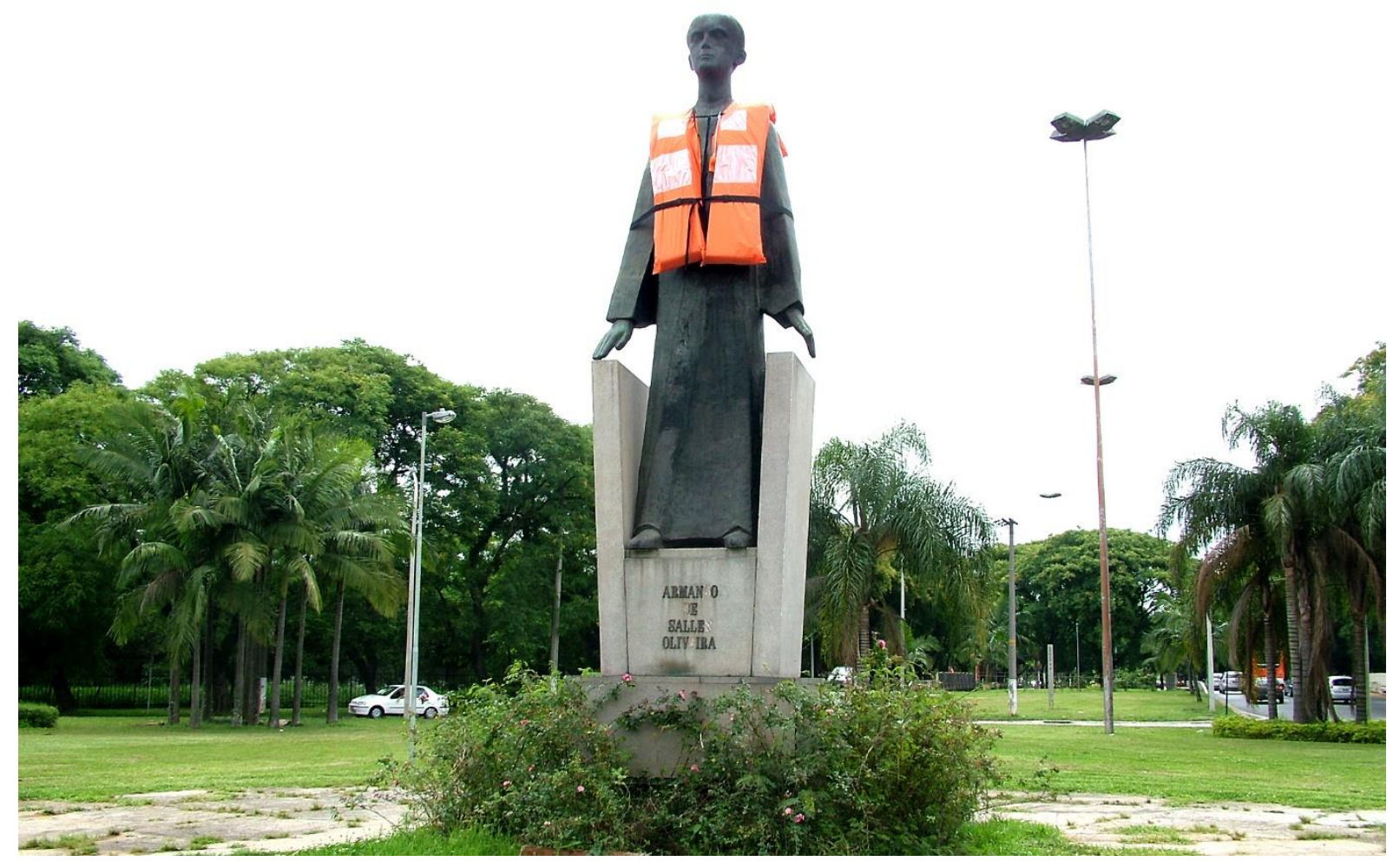

Figura 9.1. Monumento a Armando Salles de Oliveira. Intervenção artística onde foram colocados coletes salva-vidas em diversos monumentos paulistanos. 
Por outro lado, algumas destruições são justificadas pelo que representaram. Seria inconcebível para a Alemanha unificada dos anos 1990 manter um muro que a separou por quase três décadas. Entretanto, sua localização está devidamente preservada (Figuras 9.2A e B).

Uma flor é bela em seu próprio jardim, uma antiguidade é bonita no seu próprio país (Figura 9.2C).

Esta frase acima encontra-se na entrada do Museu de Éfeso, na Turquia! Talvez porque uma boa parte do patrimônio turco está devidamente distribuído em muitos museus de países ocidentais.

Certamente este não é um triste privilégio da Turquia. O museu de Atenas, ao lado da Acrópole, ainda anseia para ter os frisos do Parthenon em seu local original, uma vez que hoje se encontram no British Museum, em Londres.
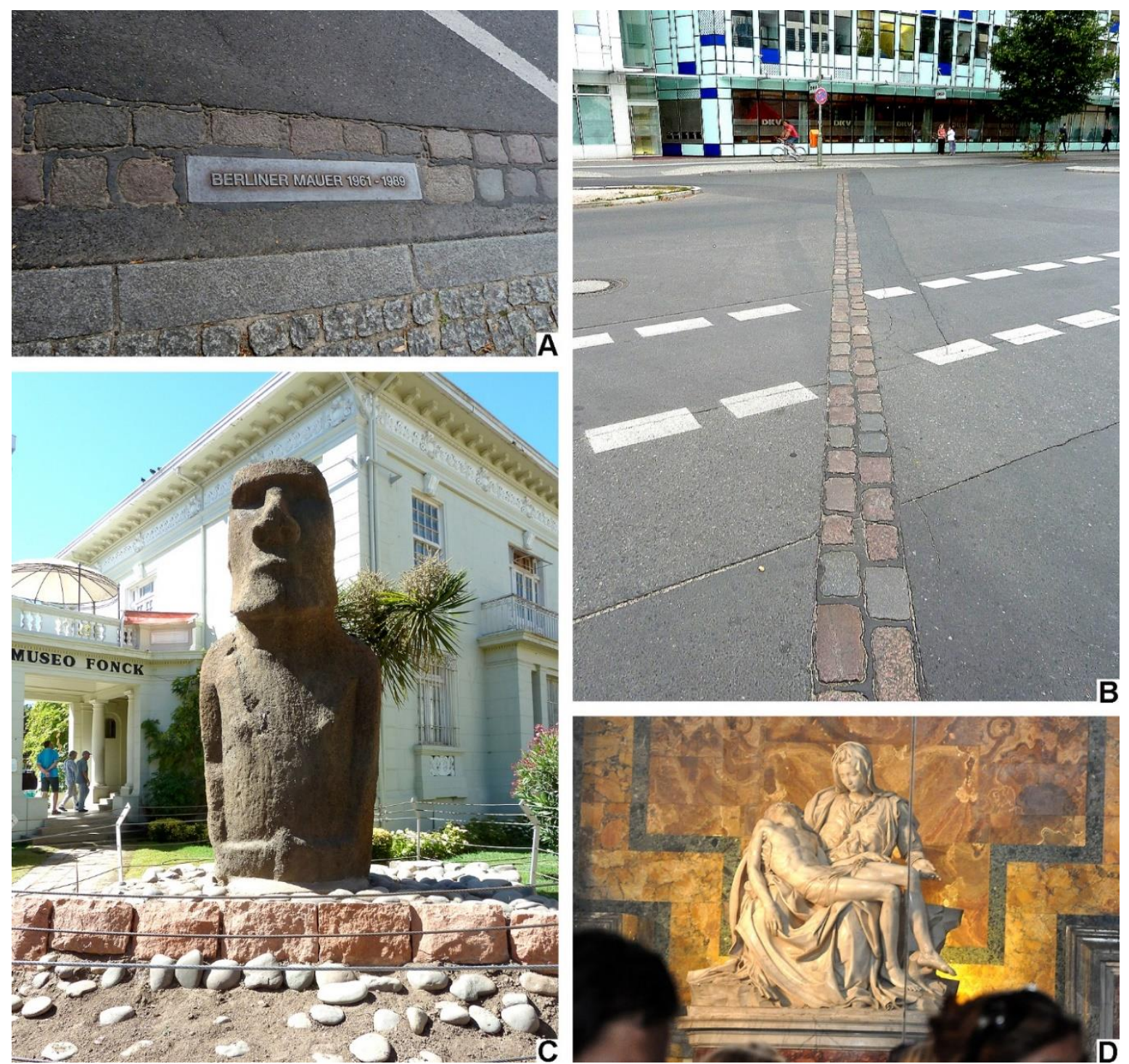

Figura 9.2. A e B. Localização do extinto Muro de Berlim, que dividiu a cidade entre 1961 a 1989. C. Moai da Ilha de Páscoa em Viña del Mar, Chile. Os moais são encontrados também no Museu de História Natural de Nova York, no Museu do Louvre e no British Museum. D. Pièta de Michelângelo, Igreja de São Pedro, Vaticano. 
Os monumentos são feitos para serem apreciados sem barreiras. Existem monumentos tanto no exterior como no Brasil, cercados por vidro ou grades. É compreensível a motivação, a Pièta do Vaticano foi isolada do público após tentativa de vandalismo em 1972 (Figura 9.2D). O vandalismo é um problema crônico, não só nos monumentos paulistanos. A educação patrimonial poderia ser instrumento para diminuir este problema, pois só se preserva aquilo que se conhece.

A execução de intervenções em monumentos, em caso de necessidade, deve obedecer a um roteiro que englobe tanto o diagnóstico das suas condições assim como levar em consideração o contexto histórico do objeto, para só então realizar a sua recuperação, de forma que sejam mantidas o seu caráter contextual histórico e que as suas características originais sejam minimamente alteradas.

A restauração é campo de atuação dos conservadores-restauradores. Um conservadorrestaurador não deve ser confundido com um cientista da conservação, e vice-versa. $O$ cientista da conservação é um profissional com conhecimento dos valores éticos e culturais da conservação, que o habilita a contribuir no estudo e conservação da herança cultural integrado em equipe interdisciplinar.

As decisões dos métodos e técnicas a serem utilizadas envolvem riscos, e só aquelas embasadas cientificamente devem ser aplicadas. Daí a importância dos estudos prévios aos trabalhos de restauração, sendo que uma fase diagnóstica prévia é que norteará a execução de uma futura intervenção.

E as intervenções, quando realizadas, devem ser datadas (Figura 9.3). Há muitos exemplos de bens culturais que foram praticamente reconstruídos em tempos recentes e está informação não está disponível para os visitantes.
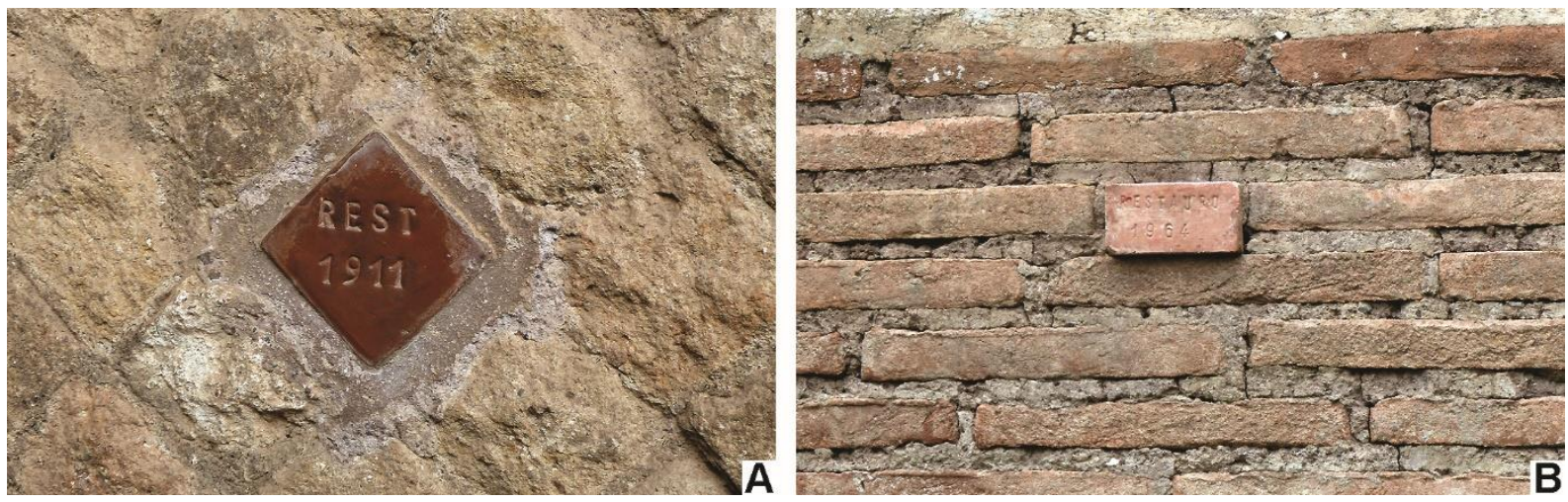

Figura 9.3. A e B. Restaurações datadas em Ostia Antica, Itália.

O Laboratório de Métodos Não Destrutivos - Herança Cultural no IGc-USP, visa a formação de recursos humanos de cientistas da conservação, com o viés do conhecimento geológico dos materiais pétreos. Para tanto, o laboratório foi equipado com instrumentos de ensaios não destrutivos para esse fim, com o apoio da Fapesp. Desta forma, o objetivo do laboratório é contribuir na resolução de problemas da sociedade civil, apoiando cientistas e praticantes da conservação e restauro de bens culturais. 
A geração de conhecimento sobre deterioração de materiais geológicos e o conhecimento de suas propriedades podem auxiliar os órgãos competentes a salvaguardar os bens arquitetônicos e culturais. Desta forma, pode-se considerar que a área de conhecimento que foi e está sendo implantada no Instituto de Geociências, está cumprindo os objetivos a que se destinou, inclusive na perspectiva de abertura de novos mercados de trabalho para o geólogo.

E com relação à disseminação e divulgação dos conceitos geocientíficos, os roteiros geoturísticos, com base na caracterização geológica dos monumentos pétreos, são muito eficazes nesta tarefa e constituem recursos de ensino para todos os níveis e idades, tendo o Instituto de Geociências da USP sido o precursor dessas atividades de geoturismo urbano na cidade de São Paulo, com a confecção de roteiros geoturísticos, e que foram objeto de matéria na mídia, tanto escrita quanto televisionada. 
E no meio do caminho...

tinha uma bota!

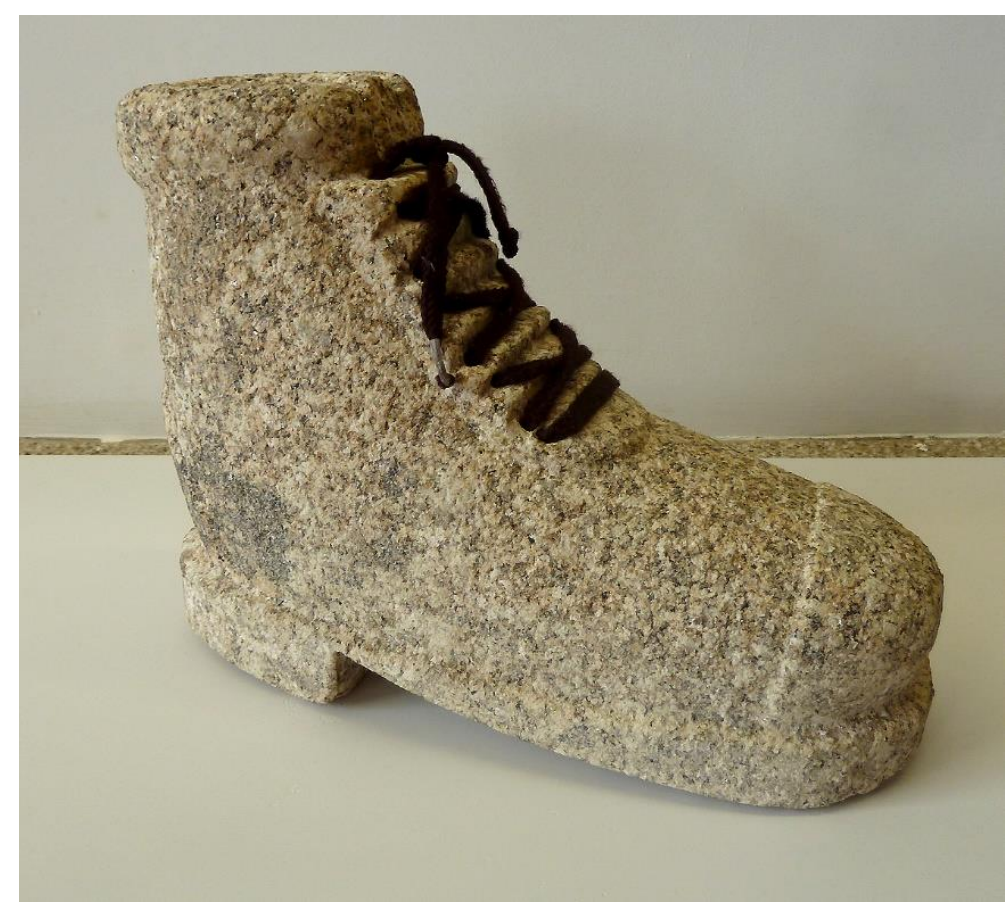

Museu da Pedra, Marco de Canavese, Portugal 